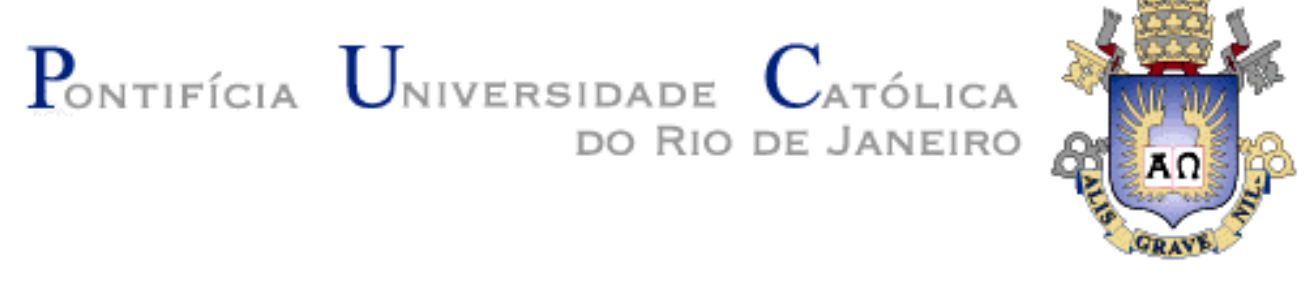

Mariana Castro Dias

\title{
PERSPECTIVAS MÚLTIPLAS: \\ Diferentes pontos de vista na ficção seriada
}

\author{
Tese de Doutorado
}

Tese apresentada como requisito parcial para obtenção do grau de Doutora pelo Programa de Pós-graduação em Comunicação do Departamento de Comunicação Social da PUC-Rio

Orientadora: Prof ${ }^{\underline{a}}$ Vera Lucia Follain de Figueiredo 


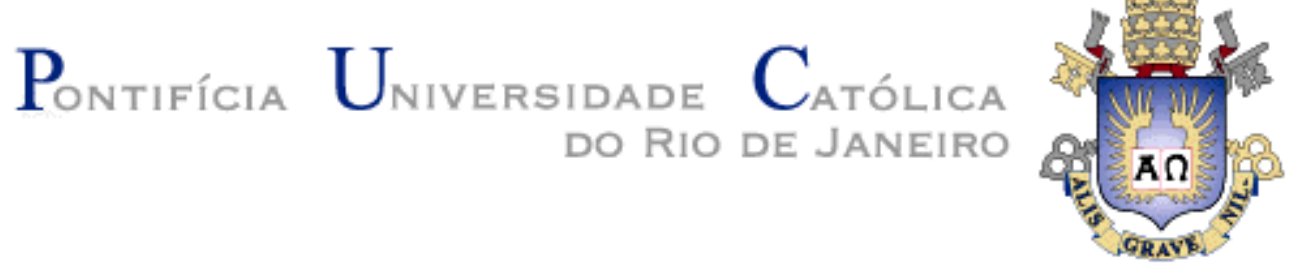

Mariana Castro Dias

\title{
PERSPECTIVAS MÚLTIPLAS: \\ Diferentes pontos de vista na ficção seriada
}

Tese apresentada como requisito parcial para obtenção do grau de Doutora pelo Programa de PósGraduação em Comunicação da PUC-Rio. Aprovada pela Comissão Examinadora abaixo

\author{
Prof ${ }^{a}$ Vera Lucia Follain de Figueiredo \\ Orientadora \\ Departamento de Comunicação - PUC-Rio
}

Prof ${ }^{\mathrm{a}}$ Tatiana Oliveira Siciliano

Departamento de Comunicação - PUC-Rio

Prof. Pedro Peixoto Curi Departamento de Comunicação - ESPM Rio

Profa. Ítala Maduell Vieira Departamento de Comunicação - PUC-Rio

Prof. Felipe de Castro Muanis Departamento de Artes e Design - UFJF 
Todos os direitos reservados. É proibida a reprodução total ou parcial do trabalho sem autorização da universidade, da autora e da orientadora.

\section{Mariana Castro Dias}

Mestre em Comunicação Social pela Pontifícia Universidade do Rio de Janeiro (PUC-Rio). Seu objeto de estudo é a ficção seriada, incluindo as narrativas transmidiáticas. Foi orientada pela Prof. Dra. Vera Lucia Follain de Figueiredo, tanto no mestrado, quanto no Doutorado. Durante o mestrado, participou do programa de intercâmbio com a Universidade Católica Portuguesa, em Lisboa. Cursou o Máster Universitario en Diseño y Comunicación da Universitat Pompeu Fabra/Elisava, em Barcelona e possui graduação em Desenho Industrial, Comunicação Visual, também pela PUC-Rio

Ficha Catalográfica

Dias, Mariana Castro

Perspectivas múltiplas : diferentes pontos de vista na ficção seriada / Mariana Castro Dias ; orientadora: Vera Lucia Follain de Figueiredo. - 2020.

234 f. : il. color. ; $30 \mathrm{~cm}$

Tese (doutorado)-Pontifícia Universidade Católica do Rio de Janeiro, Departamento de Comunicação Social, 2020.

Inclui bibliografia

1. Comunicação Social - Teses. 2. Ponto de vista. 3. Narrativa. 4. Ficção seriada. 5. Transmídia. 6. Televisão. I. Figueiredo, Vera Lucia Follain de. II. Pontifícia Universidade Católica do Rio de Janeiro. Departamento de Comunicação Social. III. Título. 


\section{Agradecimentos}

O presente trabalho foi realizado com apoio da Coordenação de Aperfeiçoamento de Pessoal de Nível Superior - Brasil (CAPES) - Código de Financiamento 001.

\section{A Pontifícia Universidade Católica e a CAPES/CNPq.}

A minha mãe que me deu força em todos os momentos, revisou toda a minha tese com muito cuidado e é sempre a melhor mãe que eu poderia desejar.

A meu pai por todo o apoio que me deu e por estar sempre presente na minha vida.

A Vera que é uma orientadora impecável. Lê tudo com atenção e dá sempre um feedback minucioso, com toda a sua sabedoria. Suas aulas e tudo o que ela fala são pura inspiração, ela tem o dom de transformar até os temas mais densos e (até chatos) em narrativas para lá de interessantes.

A Tati que foi sempre muito generosa comigo. Me abriu as portas para participar de seu grupo de pesquisa e trouxe sempre ótimas contribuições para a minha jornada, seja nas aulas, nos corredores, nas bancas ou no memorável sofá da Oprah.

A Pedro Curi que participou da minha banca de qualificação, trazendo tantas contribuições, sempre com muita generosidade.

A Felipe Muanis e a Ítala Maduell que também aceitaram o convite para fazer parte da minha banca, junto à Tati e ao Pedro. A Eduardo Miranda, Alexandre Carauta e Felipe Gomberg, que concordaram em ser suplentes.

A Nat, também orientanda da Vera, por toda o seu companheirismo e generosidade. Obrigada não só pelo livro e por dicas, mas também por seu ato lindo de ter se oferecido para me ajudar a imprimir a tese em meio ao caos por conta do covid-19, em um momento em que ainda não sabíamos o que estava por vir.

A Felipe que se ofereceu até para imprimir as milhares de folhas da tese e soube entender meus momentos sem tempo, viu todas as temporadas de Thirteen Reasons Why comigo e me deu o exemplo de futebol sobre sistemas complexos.

A Angel que igualmente se ofereceu para me ajudar a imprimir e entregar as teses e esteve do meu lado em todos os momentos mais difíceis dos últimos anos. $\mathrm{E}$ a todas as minhas queridas Desnorteadas, em especial Bellinha, Mari e Camilla.

A Marise, que me obriga a ser prolixa e agradecer novamente por tanta generosidade. A todos os professores e funcionários do departamento de Comunicação da PUC. A Vagner que preparou com capricho essa tese nas normas da ABNT. A Rafael Leal e Lucas Paraíso, com quem tanto aprendi sobre roteiro e ao meu primeiro mestre da arte de contar histórias, Daniel Herz.

Aos meus queridos colegas parceiros de aulas, congressos e de vida: Cristina Matos, Valmir, Thaís, Olga, Aurora, Carol, Helena, Ana Paula, Tati e Flavinha.

A tia Lulu e todos os meus amigos que sempre estiveram ao meu lado.

E finalmente, mas não menos importante, à minha querida avó que é sempre um exemplo de vida com sua positividade 


\section{Resumo}

Dias, Mariana Castro; Figueiredo, Vera Lucia Follain de. Perspectivas múltiplas: Diferentes pontos de vista na ficção seriada. Rio de Janeiro, 2020. 234 p. Tese de Doutorado - Departamento de Comunicação Social, Pontifícia Universidade Católica do Rio de Janeiro.

As séries de ficção estão entre as principais fontes de entretenimento nos últimos anos, fazendo parte do dia a dia e dos diálogos travados por um grande número de pessoas. $\mathrm{O}$ aumento de opções de plataformas para o consumo deste tipo de conteúdo e a tecnologia de video on demand (VOD) foram alguns dos principais fatores que permitiram a oferta de mais títulos de séries simultaneamente, com a possibilidade de acessá-los em um banco de dados, inclusive de alcance mais global. O estudo da ficção seriada é um campo de aumento de interesse acadêmico, mas ainda aquém em pesquisa, perante a relevância do tema, até para um melhor desenvolvimento do mercado brasileiro. O foco deste trabalho está no estudo da ficção seriada que entrelaça diferentes pontos de vista. As narrativas que apresentam múltiplas perspectivas chamam atenção para a relatividade da verdade e para o fato de que a realidade é construída. Serão analisadas séries de ficção que trabalham nessa lógica de perspectivas múltiplas, seja em um mesmo episódio, como a série norte-americana The Affair; seja na mistura entre episódios e temporadas, como em Thirteen Reasons Why; ou a partir da serialização por diferentes plataformas, como a websérie transmídia The Lizzie Bennet Diaries; ou a série norueguesa Skam, que além de ser transmídia muda de protagonista, entre os alunos de uma mesma escola, a cada temporada.

\section{Palavras-chave}

Ponto de vista; narrativa, ficção seriada, transmídia, televisão. 


\section{Abstract}

Dias, Mariana Castro; Figueiredo, Vera Lucia Follain de. (Advisor). Multiple perspectives: Different points of view in serial fiction. Rio de Janeiro, 2020. 234p. Tese de Doutorado - Departamento de Comunicação, Pontifícia Universidade Católica do Rio de Janeiro.

Fictional series are among the main entertainment activities in recent years, being part of the daily life and social debate of a number of people. The increase in platform offer for the consumption of this type of content and the video on demand technology (VOD) were some of the main factors that allowed the offer of more serial titles simultaneously, with the possibility of accessing them in a databank, including a higher global reach. The study of serial fiction is gaining academic interest, but it is still small given the relevance of the theme, even for a better development of the national market. The focus of this work is the study of serial fiction that combines different points of view. Narratives that present multiple perspectives call attention to the relativity of truth and the fact that reality is created. Fictional series that operate on this logic of multiple perspectives will be analyzed, whether in the same episode, such as the North American series The Affair; or in a mix of episodes and seasons, as in Thirteen Reasons Why; or from serialization in different platforms, such as the transmedia web series The Lizzie Bennet Diaries; or the Norwegian series Skam, that besides being transmedia, changes each season its protagonist, among students of the same school.

\section{Keywords}

Point of view, narrative, fictional series, transmedia, television. 


\section{Sumário}

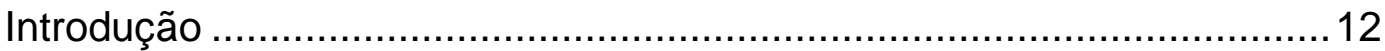

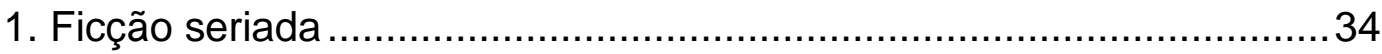

1.1. Uma narrativa em fatias ................................................... 34

1.2. A ficção seriada televisiva como campo de estudo ........................39

1.3. Breve histórico da ficção seriada audiovisual ................................44

2. Narrativas que revelam múltiplos pontos de vista ...........................66

2.1. Uma questão de perspectiva...................................................68

2.2. Narração e ponto de vista ..................................................... 74

2.3. Efeito Rashomon ................................................................. 79

2.4. Ponto de Vista x Plano Ponto de Vista .........................................86

3. Ilusão biográfica e ação da memória em The Affair ...........................92

3.1. Uma narrativa composta por diferentes perspectivas ....................92

3.2. Relatos, identidade, história de vida e ilusão biográfica ..................98

3.3. O impacto da ficção na realidade dos personagens.....................105

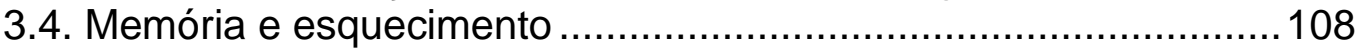

3.5. Toda regra tem sua exceção - será? ....................................... 111

3.6. Estrutura narrativa ........................................................... 114

3.7. Alucinações ........................................................................ 117

3.8. O impacto do psicológico na perspectiva ..................................119

3.9. Xeque mate: o paradoxo como parte do jogo ............................121

4. Thirteen Reasons Why - Construção e desconstrução narrativa .......124

4.1. Sobre a série: sucesso e polêmicas........................................124

4.2. Como tudo começou ................................................................ 129

4.3. Apresentação dos personagens ............................................... 131

4.4. Arcos narrativos ................................................................... 139

4.5. Revelados, ocultados e contraditos........................................ 150

4.6. Construção narrativa ............................................................ 156

5. Multiperspectiva e transmídia........................................................ 173

5.1. Sobre transmídia e os objetos que serão analisados..................173

5.2. O tempo como fator que influencia a adaptação ..........................186

5.3. Orgulho e Preconceito no formato transmídia ..............................188

5.4. Skam, a série local que se tornou global...................................198

5.5. O formato transmídia em Skam................................................201

5.6. Construção narrativa em Skam ............................................206

5.7. Ponto de vista em Skam ......................................................209

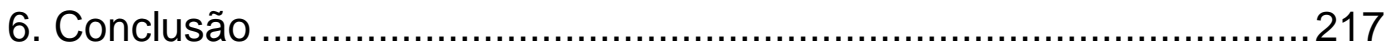

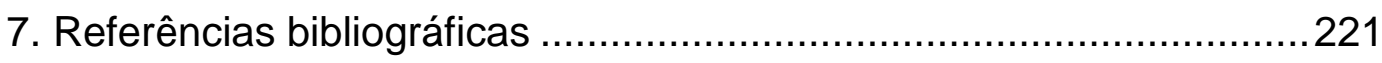

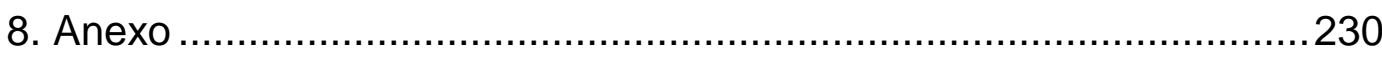




\section{Lista de figuras}

Figura 1 - Alison na visão de Noah e em sua própria visão......................97

Figura 2 - Noah visto por ele mesmo e por Alison ..................................97

Figura 3 - Helen vista por Noah e por Alison .........................................97

Figura 4 - Vestido de Alison por Noah, por ela e pela câmera de

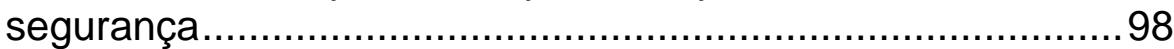

Figura 5 - As visões de Alison e de Helen ..........................................119

Figura 6 - Linhas temporais da primeira temporada ............................. 140

Figura 7 - Linhas temporais da segunda temporada ............................ 142

Figura 8 - Fantasma de Hannah na vida de Clay .................................145

Figura 9 - Linhas temporais da primeira temporada ............................ 147

Figura 10 - Passagem de tempo passado para tempo presente na terceira temporada. ........................................................... 148

Figura 11 - Plano do olhar de Clay seguido por seus planos ponto de vista: Hannah e sua mãe na janela.

Figura 12 - Plano do olhar de Hannah e Clay, olhando Jessica e Alex em temporalidades diferentes.

Figura 13 - Clay e Olívia entram na casa no tempo presente, saem os pais de Hannah no tempo passado.

Figura 14 - Plano detalhe propiciando a mudança de temporalidade....159

Figura 15 - Presença mútua de personagens de temporalidades diferentes no mesmo quadro.

Figura 16 - Cena no carro de Clay do tempo passado costurando com cena do tempo presente, na terceira temporada.

Figura 17 - Pacote de Skittles acompanha Clay na passagem de tempo.

Figura 18 - O tempo passado se revela com a passagem da professora pelo plano ponto de vista de Clay

Figura 19 - A imagem de Hannah da recordação de Clay some com o passar dos transeuntes.

Figura 20 - Giro que faz o passado aparecer por trás da silhueta.........163

Figura 21 - Diferentes planos de uma mesma cena de menos de $1: 37$

Figura 22 - Câmera acompanhando personagens. ...............................164

Figura 23 - Diferentes tons de azul no armário....................................166

Figura 24 - Monets na primeira temporada. ......................................167

Figura 25 - Monets na terceira temporada, no tempo passado e no tempo presente 
Figura 26 - Diferenças nos tons das cores no tempo passado e tempo presente. (primeira temporada) .............................. 168

Figura 27 - Quadro cromático primeira temporada...............................169

Figura 28 - Quadro cromático segunda temporada............................169

Figura 29 - Quadro cromático terceira temporada - Tempo presente...170

Figura 30 - Quadro cromático terceira temporada - Tempo passado. ..170

Figura 31 - Terceira temporada - Tempo presente/futuro.....................171

Figura 32 - Crossmídia x Transmídia. ............................................ 174

Figura 33 - Desenho de fã e composição cênica desenvolvida em

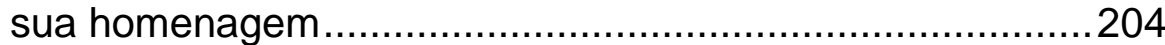

Figura 34 - Da esquerda para direita: Chris, Vilde, Eva, Noora e

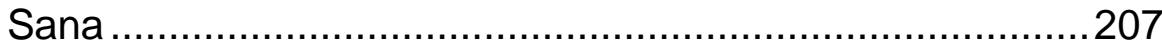


Encontrei hoje em ruas, separadamente, dois amigos meus que se haviam zangado um com o outro. Cada um me contou a narrativa de por que se haviam zangado. Cada um me disse a verdade. Cada um me contou as suas razões. Ambos tinham razão. Ambos tinham toda a razão. Não era um que via uma coisa e outro outra, ou que um via um lado das coisas e outro um lado diferente. Não: cada um via as coisas exactamente como se haviam passado, cada um as via com um critério idêntico ao do outro, mas cada um via uma coisa diferente, $e$ cada um, portanto, tinha razão. Fiquei confuso desta dupla existência da verdade.

Fernando Pessoa 


\section{Introdução}

Em um de seus poemas, Fernando Pessoa conta sobre a espantosa experiência de um eu-lírico que encontra com dois amigos que haviam brigado entre si e, ao ouvir seus relatos, percebe que ambos dizem a verdade e têm razão. Cada amigo via coisas diferentes, apesar de as verem exatamente como haviam passado, revelando uma dupla existência da verdade.

Seria possível, então, cada personagem do poema possuir uma verdade diferente? Sendo assim, a verdade seria algo relativo? Ao mudar o referencial, o ponto de vista daquele que relata, seria possível mudar a verdade ou mesmo mudar a realidade? A realidade seria então construída, assim como a verdade e, desse modo, uma interpretação e não um valor absoluto?

Essas são algumas das perguntas que norteiam essa tese, centrada no estudo de obras de ficção seriada que, de alguma maneira, abrangem diferentes pontos de vista em um mesmo universo ficcional. As narrativas analisadas apresentam histórias que alternam perspectivas, seja em um mesmo episódio, em temporadas distintas ou em diferentes plataformas.

A ficção seriada, em especial as séries de TV, se tornaram uma das mais importantes fontes de entretenimento nos últimos anos. Segundo dados publicados pela Netflix em 2019, todos os dias, 18 milhões de brasileiros assistiam a séries internacionais na plataforma, o que corresponde a um crescimento de $80 \%$ frente a $2018^{1}$. O Kantar Ibope Media revelou um grande aumento nos minutos dedicados ao consumo de séries em plataformas de streaming ${ }^{2}$ : em 2010 correspondiam a $2 \%$ do consumo, em 2019 essa porcentagem mudou para $51 \%{ }^{3}$.

A ficção sempre foi um convite para se colocar no lugar do outro, e a ficção seriada permite acompanhar a vida deste outro, ao longo de um arco temporal mais prolongado. Ao oferecer múltiplas perspectivas, esse tipo de série é capaz de nos lembrar que não existe uma história única, mas interpretações.

\footnotetext{
${ }^{1}$ Dados disponíveis em https://exame.abril.com.br/estilo-de-vida/netflix-divulga-as-seriesinternacionais-preferidas-pelos-brasileiros/

${ }^{2}$ Streaming é uma forma de difundir dados, de maneira contínua, muito usada na internet.

${ }^{3}$ Dados disponíveis em https://www.em.com.br/app/noticia/cultura/2019/12/30/interna_cultura,1111014/as-series-de-tvque-marcaram-2019-realidade-renovou-a-ficcao.shtml
} 
A série audiovisual levou para as telas da TV produtos fortemente influenciados pelo cinema e pelo rádio, mas seu modo de narrar é tributário principalmente do romance folhetim do século XIX, sem desmerecer a influência também das radionovelas e das telenovelas. Ambos trazem, para o cotidiano de seu público, histórias oferecidas em fatias, as quais se parecem com encontros marcados com os personagens e seus dramas. Esses personagens se tornam cada vez mais familiares ao público, e, por vezes, quando as séries se prolongam por muitos anos, parece que vivem uma vida paralela à de seus fãs e, com eles, amadurecem.

O sucesso das séries torna seu conteúdo assunto de toda uma comunidade. Muitos até acompanham séries que não teriam escolhido preferencialmente ver para não ficar de fora das discussões. Isso torna esse tipo de produto audiovisual um palco em potencial para questões e temas serem debatidos. $\mathrm{O}$ fato de se manterem em exibição durante um longo tempo é uma oportunidade de manter o debate em voga em um mundo de excesso de informação.

As narrativas seriadas audiovisuais podem ser vistas na TV aberta, cabo, em plataformas de streaming, video on demand ${ }^{4}$ (VOD), rede sociais ou compartilhadas clandestinamente em google drives. Seja qual for o canal de distribuição, seu conteúdo movimenta um grande mercado de consumidores e fãs, que podem consumir as séries em doses homeopáticas semanais ou fazer bingewatching ${ }^{5}$ de toda uma temporada.

O cardápio de séries disponíveis é tão vasto que foram desenvolvidos até aplicativos para auxiliar os fãs a estarem em dia com suas séries favoritas.

Séries como Game of Thrones se tornaram as estrelas da atenção pública, modificando até a forma de lançamento dos episódios. Antes eles eram lançados em seus países de origem e depois chegavam aos demais mercados. A HBO inaugurou o lançamento mundial quase simultâneo, permitindo que todos pudessem

\footnotetext{
${ }^{4}$ Video On demand é o vídeo disponível para ser assistido quando o espectador assim desejar. O espectador escolhe o vídeo em uma plataforma e o assiste via internet.

${ }^{5}$ Bingewatching - Em pesquisa realizada pela Netflix em 2013, a empresa definiu binge-watching como o ato de assistir mais de 2-3 episódios de um mesmo programa de uma vez frequentemente. (https://variety.com/2013/digital/news/netflix-survey-binge-watching-is-not-weird-or-unusual$\underline{1200952292 /)}$
} 
assistir e tomar parte de uma conversação mundial, sem spoilers $^{6}$ e sem ter que piratear episódios para não ficar atrasado frente aos demais fãs.

Essas novas formas de veiculação e consumo precisam ser levadas em consideração na produção. O cenário é propício para o desenvolvimento de narrativas mais complexas, que não precisam se preocupar tanto com rememorações, redundâncias, e outros artifícios que as séries tradicionais precisavam manter, já que grande parte do seu público podia não ter visto o capítulo anterior e não tinha recursos fáceis, como wikis ${ }^{7}$, fóruns e sites de internet para buscar o conhecimento não adquirido.

Ainda que a maior parte dos objetos que serão analisados tenha como meio principal de veiculação a televisão, convém destacar que foge ao escopo dessa tese o aprofundamento de discussões sobre o meio televisivo e as mudanças pelas quais ele tem passado. Tampouco entrarei em discussões sobre a qualidade da TV. Apesar de entender a importância desse debate, por conta do estigma que essa mídia sofreu, acredito que este assunto já foi muito bem debatido por outros pesquisadores e que o meu corpus de estudo não traga novas nuances para esta discussão. A TV abrange diversos tipos de produtos de naturezas bastante distintas. Quando falamos em cinema, por exemplo, imaginamos um filme, de ficção ou documental, com cerca de 2 horas. Claro que isso pode variar, mas há uma semelhança maior do que quando pensamos em um meio que abriga noticiários, reality shows, diversos tipos programas de auditório, programas de vendas de produtos, séries, novelas e até filmes, além de muitos outros. Essa tese concentra-se apenas em um desses muitos produtos: a série. Além disso, como dissemos anteriormente, a série não é só um produto assistido na TV: ela pode ser assistida no computador, no celular, em diferentes telas. A TV é uma tela, parte de uma ecologia de múltiplas telas, a partir da qual pode ser visto um conteúdo. O produto então, por mais que possa ser concebido tendo em consideração uma mídia específica, transita entre telas. Antes até se pensava, por exemplo, que séries para internet tinham quer ser mais curtas, mas hoje isso nem é necessariamente uma realidade, até porque uma série postada

\footnotetext{
${ }^{6}$ Spoiler vem do verbo to spoil que significa estragar, diz respeito a quando alguma outra pessoa (ou site, podcast, etc) revela alguma informação antes que você veja o desenrolar de uma série, filme, livro, ou outro produto cultural, estragando, de alguma forma, a sua experiência.

${ }^{7}$ Wikis são páginas web colaborativas, onde os próprios usuários das páginas podem editar, adicionar ou eliminar informações. As wikis, em geral, possuem uma infinidade de conteúdos organizados pelos fãs.
} 
no youtube também pode ser vista em um aparelho de smart $T V$, em uma tela grande, diante de um sofá confortável, no centro da sua sala. Torna-se mais relevante entender os hábitos de consumo do público-alvo de um produto para determinar certas características, do que se manter em noções estereotipadas dos meios.

Além disso, as séries podem se expandir por diferentes plataformas, oferecendo conteúdos complementares para quem as acessar. Essa experiência, que une múltiplas plataformas e a presença de informações adicionais em cada uma delas, configura uma experiência que denominamos narrativa transmídia ou narrativa transmidiática.

A terminologia transmídia se tornou uma buzzword $^{8}$ na década de 2010 . Foi usada pela mídia e pelo marketing, até como uma forma de chamar atenção para determinados produtos, conferindo-lhes um certo glamour de inovadores, inclusive sendo relacionada com produtos que não poderiam ser assim considerados de fato.

Durante o período da minha dissertação, que foi desenvolvida entre 2012 e 2015, observei que o termo foi utilizado de maneira controversa com diversos significados por diferentes pesquisadores. (DIAS, 2015) No momento de escrita dessa tese, 2020, já há um maior consenso sobre sua definição e sobre o enquadramento de produtos sob esse rótulo. Minha grande preocupação em meus estudos sempre foi atentar para a natureza da expansão de conteúdo narrativo através de diferentes plataformas como uma possível forma de contar histórias dentre muitas outras, nem melhor nem pior, apenas específica.

O termo se popularizou através de seu uso pelo pesquisador norte-americano Henry Jenkins que se apropriou do termo transmídia, usado pela pesquisadora Marsha Kinder como parte da expressão transmedia intertextuality. Kinder pensa a transmídia como uma expansão de um produto cultural, caso, por exemplo, de um personagem de desenho animado circulando por outros produtos culturais ou mesmo físicos, tais como lancheiras, brinquedos, cadernos, entre muitos outros. Ele também pode virar mascote propaganda de uma marca de produtos alimentícios ou garantir que um novo filme faça sucesso. Kinder se preocupa com essas relações intertextuais e com a circulação entre mídias desses personagens que incentivam o

\footnotetext{
${ }^{8}$ Buzzword se refere a um termo que vira moda e tem seu uso popularizado por um período de tempo.
} 
consumo, principalmente de crianças. (KINDER, 1991) Jenkins trouxe o conceito para o âmbito da narrativa e manteve a questão da transição do conteúdo entre mídias com conteúdos que dialoguem no nível narrativo.

Jenkins mencionou o termo pela primeira vez em seu artigo do MIT, em 2003, mas foi com seu livro de sucesso Cultura da Convergência, publicado nos Estados Unidos em 2007 e no Brasil em 2009, que o termo ganhou o mundo.

Narrativa Transmidiática (Transmedia Storytelling) representa o processo em que os elementos que integram uma ficção são dispersados sistematicamente, através de múltiplas plataformas, com o propósito de criar uma experiência de entretenimento única e coordenada. Idealmente, cada meio deve oferecer sua contribuição para o desdobramento da história. (JENKINS, 2011b, n.p.) $)^{9}$

A narrativa transmídia deve então expandir o universo narrativo e não constituir uma simples transposição de suporte. Ainda que o termo tenha se tornado controverso, no sentido de diferentes pesquisadores o adotarem de maneira nem sempre semelhante, Jenkins não se envolveu nas discussões de definição até que publicou alguns artigos em seu blog, Confessions of an Aca-Fan, (mistura dos termos acadêmico e fã), entre março de 2007 e início de 2011, onde propôs alguns acréscimos e revisões. Entre elas sintetizou que, para uma narrativa ser considerada transmídia, é preciso que ela junte multimodalidade com intertextualidade radical, com o propósito de compreensão aditiva. Ou seja, o texto precisa estar presente em mais de uma mídia e seus fragmentos precisam conversar entre si, adicionando camadas de conhecimento à história. (JENKINS, 2011b)

Iremos retornar brevemente a esse assunto no capítulo 1 e nele nos aprofundar no capítulo 5. No momento, o que é importante destacar é que a narrativa transmídia é também uma narrativa serializada, sendo que seus fragmentos estão dispersos não apenas em uma única mídia. Aproveito esse gancho para apresentar os objetos e as temáticas que iremos abordar nos próximos capítulos, começando pelo último e terminando pelo primeiro, considerando que essa ordem reversa, apesar de quebrar, aparentemente, uma linearidade, serviu melhor para conduzir nossa introdução.

\footnotetext{
${ }^{9}$ Tradução minha: Transmedia storytelling represents a process where integral elements of a fiction get dispersed systematically across multiple delivery channels for the purpose of creating a unified and coordinated entertainment experience. Ideally, each medium makes it own unique contribution to the unfolding of the story. (JENKINS, 2011b, n.p.)
} 
No capítulo 5, as séries de The Lizzie Bennet Diaries e Skam nos conduzirão a um passeio pela narrativa multiperspectiva que abrange diferentes plataformas.

The Lizzie Bennet Diaries é uma adaptação atualizada e transmidiática de Orgulho e Preconceito, livro de Jane Austin (1813), desenvolvida em 2012 pela empresa norte-americana Pemberley Digital. A protagonista Lizzie tem um vlog ${ }^{10}$, que funciona como a mídia principal. Lá ela tece comentários sobre todos os personagens da trama sob as marcas de sua visão, muitas vezes preconceituosa, principalmente a respeito de seu futuro par romântico William Darcy. Fazendo referência ao título da obra original, Lizzie representa o preconceito, enquanto William, o orgulho. E como é saber de uma história a partir de um ponto de vista preconceituoso? Uma das saídas para fugir a essa visão única e pessoal é buscar por outros pontos de vistas, presentes em outras mídias ou outros canais. Desde o início, era possível acompanhar os perfis do twitter de quase todos os personagens. A irmã de Lizzie mais velha, Jane, também tinha um blog de moda, enquanto a mais nova, Lydia, ao se revoltar com a irmã, criou seu próprio vlog. Além disso, a empresa de William tinha uma plataforma própria de vídeo e a melhor amiga de Lizzie, Charlote, trabalhava em uma empresa que também tinha um site onde o público podia contribuir enviando vídeos.

Analisei esse objeto em minha dissertação de mestrado. Ele me chamou atenção para o potencial de trabalhar a subjetividade em uma narrativa transmídia. Decidi revisitá-lo como um ponto de partida para elucidar os conceitos de narrativa transmídia e, a partir daí, extrair reflexões que ajudarão no estudo da série Skam.

A lógica de engajamento, que faz com que uma pessoa vá de uma mídia para outra a procura de conteúdo, é semelhante à lógica do bingewatching: em ambos os casos o espectador tem acesso a uma fatia de conteúdo e quer saber mais sobre aquela história.

Skam é uma série adolescente norueguesa, produzida pela rede pública NRK. Inicialmente destinada para a plataforma digital do canal, seu sucesso foi tamanho que ela entrou não só para sua grade televisiva, mas também foi licenciada para ganhar versões em diferentes países.

\footnotetext{
${ }^{10}$ Vlog é um canal de vídeo que funciona como um diário.
} 
A presença em diferentes plataformas também é comum aos personagens de Skam. Além de ser possível acompanhá-los nas redes sociais, a série (original norueguesa) possui quatro temporadas que contam a história de um grupo de adolescentes que estuda na escola Niessen. Cada temporada tem um dos estudantes como protagonista, aprofundando os seus anseios e dilemas. Entre eles estão Eva, que tenta encontrar seu lugar em uma nova escola; Noora, que precisa lidar com um relacionamento complicado e a sombra de um abuso; Isak, que vive um relacionamento homossexual e precisa se liberar de estigmas e preconceitos próprios; e Sana, muçulmana que quer se inserir na sociedade norueguesa, mas sem abrir mão de sua religião. A premissa da série é "todos que você conhece estão lutando uma batalha sobre a qual você não sabe nada".

Poderíamos ter em conta essa premissa também para a análise da série norteamericana Thrirteen Reasons Why, estrela do nosso capítulo 4, adaptação de Brian Yorkey, para a Netflix, do livro de mesmo nome de Jay Asher (2007). A série também se passa em uma escola de ensino médio, mas esta foi assolada por um acontecimento bastante sombrio: o suicídio de uma de suas alunas, Hannah. Até o momento de escrita dessa tese, ela contava com três temporadas, com 13 episódios cada. Uma quarta temporada fechou, posteriormente, ainda em 2020, a saga que se iniciou em 2017. Na primeira temporada, cada episódio revela, a partir das fitas cassete deixadas por Hannah, um dos treze motivos que a fizeram decidir por acabar com a própria vida. Acompanhamos o protagonista Clay na descoberta da história deixada por sua amiga e amor não correspondido. Se alguns fatos narrados já o confundem na primeira temporada, na segunda cada episódio é narrado por um dos acusados nas fitas e eles revelam informações adicionais ou contraditórias, ora mentem, ora colocam em dúvida a história construída por Hannah. Nessa segunda temporada, o protagonismo já é mais compartilhado entre um núcleo de personagens principais. Na terceira temporada surge uma nova personagem como narradora da história, Ani, que tenta entender que segredos são esses que permeiam a vida de seus colegas e, junto a Clay, tenta desvendar um caso de assassinato. A terceira temporada dá um toque de gênero policial à série, que sempre envolveu mistérios nas entrelinhas dos discursos dos personagens. Vamos entender como se dá a construção de sua dinâmica narrativa, analisando não só a questão dos pontos de vista - como as narrativas se constroem e se reconfiguram, a partir de outros 
olhares - mas também os mecanismos que lhe conferem dinamismo nas costuras entre suas diferentes temporalidades.

O capítulo 3 analisa a série também norte-americana The Affair (20142019), dos criadores Sarah Treem e Hagai Levi, produzida para o canal Showtime. De forma resumida, podemos dizer que a série retrata visões da história do amor extraconjugal dos personagens Noah Solloway e Alison Bailey, e de seus respectivos conjugues, Helen e Cole. Os episódios são divididos em partes, em geral duas, onde cada parte é composta por uma sequência de cenas que correspondem ao ponto de vista de um personagem em específico. Em alguns episódios, o mesmo período de tempo é relatado nas diferentes perspectivas, já, em outros, os relatos se complementam como recortes temporais consecutivos. O ponto de vista sofre a ação da memória e da subjetividade com que cada personagem reconstitui os fatos ocorridos.

Para a análise mostrou-se necessário entender os mecanismos a partir dos quais os relatos são construídos, tais como a construção social da realidade, os conceitos de verdade e de mentira, além de outros atributos, como a ação do tempo, que podem ser apropriados para a formação da visão subjetiva de personagens ficcionais. O capítulo 2 concentra-se nesses processos que servem de ferramenta conceitual mais geral para a compreensão das sérias analisadas. Conceitos mais específicos relacionados a cada objeto serão analisados em seus próprios capítulos. Nas narrativas multiperspectivas, os relatos muitas vezes podem ser divergentes, disputando a construção de sentido da história. A diferença pode ter motivos variados: o personagem pode estar falando o que considera verdade ou mentindo em proveito próprio. Quando não se consegue chegar a uma conclusão sobre os acontecimentos, por conta da ambiguidade dos relatos, dá-se o nome de efeito Rashomon, uma homenagem ao filme de Akira Kurosawa, de 1950, precursor da apresentação deste tipo de narrativa no audiovisual. O filme, como veremos também no capítulo 2, possui uma estrutura narrativa onde não é possível obter a verdade sobre um acontecimento, devido ao conflito de informações presentes nos diferentes testemunhos que relatam a história.

No capítulo 1, falaremos sobre o formato serializado, sua evolução ao longo do tempo e do gênero narrativo série audiovisual, antes de adentrar no tema central e na análise dos objetos. O estudo da ficção seriada audiovisual ainda é recente e 
possui várias lacunas a serem exploradas, demandando produção bibliográfica sobre o tema. Nos últimos anos, com a lei 12.485 que obriga os canais pagos a terem pelo menos 3 horas e meia de conteúdo nacional, houve um aumento da demanda por produções locais, levando à profissionalização do mercado e ao aumento da oferta de trabalho para, entre outros profissionais da indústria audiovisual, os roteiristas. Esse aumento da demanda também amplia a relevância de estudos sobre dramaturgia, a fim de que a produção televisiva brasileira possa elevar seu patamar também no formato de séries de ficção que vão além da tradicional novela.

Ao longo dessa tese muito irá se falar sobre séries complexas, denominação que pode ser tão controversa quanto transmídia. Antes, porém, a fim de termos uma melhor compreensão dessa natureza de narrativa, atentemos para o que Machado considerou como os três principais tipos de narrativa seriada na ficção: o teleológico, os episódios unitários e os episódios independentes (MACHADO, 2000). Vou descrever suas características e traçar uma relação com a divisão e a nomenclatura hoje mais corrente em cursos de roteiro.

O tipo teleológico apresenta episódios seriados de uma única narrativa (ou várias entrelaçadas e paralelas) que se sucedem, de modo mais ou menos linear, ao longo de todos os capítulos. No início da série é estabelecido o conflito que cria um desequilíbrio estrutural para o/os personagem/ns e todo o desenrolar da narrativa visa reestabelecer esse equilíbrio.

Esse modelo corresponde ao das séries mais contínuas (ou evolutivas) ${ }^{11}$, que possuem capítulos dependentes e sequenciais. A palavra "teleológico" significa fazer uma relação de um fato com sua causa, ou seja, as ações são organizadas em uma lógica de causa e consequência. As séries complexas estariam também nessa categoria, mas, em geral, não de uma maneira linear, e sim de uma maneira mais fragmentária temporalmente, cuja costura reestabelece as relações causais. Também fazem parte dessas categorias as telenovelas e minisséries.

Nos episódios unitários, cada emissão é uma história completa e autônoma, com começo, meio e fim, e o que se repete no episódio seguinte são apenas os mesmos personagens principais e uma mesma situação narrativa. Em geral, nessa

\footnotetext{
${ }^{11}$ Evolutivas não no sentido de haver um aprimoramento, mas no sentido de evolução em uma linha temporal.
} 
modalidade, um episódio não se recorda dos anteriores, nem interfere nos posteriores. Seria possível embaralhá-los sem que a situação se modificasse. Por exemplo, o personagem Kenny de South Park que morre em todos os episódios e no seguinte está vivo, como se nada tivesse acontecido.

As séries chamadas procedurais se enquadram nessa categoria, como as séries de resoluções de casos criminais ou casos médicos. Esse modelo continua existindo, mas cada vez mais o caso da semana é conjugado a um arco mais longo de evolução dos personagens na temporada.

Nos episódios independentes, cada unidade é uma narrativa independente, onde a única coisa que é preservada nos vários episódios é o espírito geral da história ou tema. É comum que tudo mude, personagens, atores, cenários e, às vezes, até roteiristas e diretores. The Outer Limits, por exemplo, é uma série em que cada episódio tem uma história diferente, com personagens diferentes e a única semelhança é que um alienígena invadiu o Planeta Terra e é preciso exterminá-lo ou mandá-lo de volta.

Chamamos este tipo de série de antologia. O exemplo mais conhecido hoje que segue esse modelo é Black Mirror, cujos episódios mantém em comum a temática distópica tecnológica.

Machado explica que muitas estruturas são misturas entre esses estilos. (MACHADO, 2000) Uma série de episódio unitários, por exemplo, pode ter em seu início o estabelecimento de um conflito, com a determinação de objetivos, e até um ponto final, em que seus personagens atinjam a meta, como ocorre na série teleológica, mas, diferentemente desta, seus outros episódios que não sejam o primeiro e o último podem ser vistos em qualquer ordem sem que se perca o sentido.

Para o autor:

A riqueza da serialização televisual está, portanto, em fazer dos processos de fragmentação e embaralhamento da narrativa uma busca de modelos de organização que sejam não apenas mais complexos, mas também menos previsíveis e mais abertos ao papel ordenador do acaso. (MACHADO, 2000, p. 97)

Essa discussão será aprofundada no capítulo 1, onde faremos um breve levantamento sobre a história da TV, tendo como foco a produção norte-americana, por conta de seu pioneirismo, sendo relacionada ao nascimento das séries, que 
influenciaram esse modo de narrar fragmentado. $\mathrm{O}$ fato é que a série se tornou um produto de grande apelo comercial para as emissoras, pois garante a volta do público que foi cativado na semana anterior, assim como o que ocorria com o romance folhetim, que garantia a venda do jornal da próxima semana.

No início da TV norte-americana, comercialmente, o modelo de ficção seriada menos arriscado era o das séries episódicas, por uma série de fatores, incluindo a falta de interesse pelo formato por conta das emissoras acharem que o público não se lembraria do que aconteceu na semana anterior ou que não veria todos os episódios e não quererem se comprometer com a exibição em ordem cronológica. Depois percebeu-se que as séries mais contínuas apresentavam vantagens que acabaram por ofuscar as séries episódicas, relativas a um maior engajamento da audiência que não quer perder o próximo capítulo da série que segue. Tudo isso tem a ver com o contexto de cada momento e aos hábitos de consumo de seu público. A TV começou com antologias e hoje temos algumas antologias de sucesso, entre elas Black Mirror, que possui um público cativo, mesmo não tendo um gancho narrativo para outro episódio.

Antes de tudo é importante esclarecer que o fato de uma série ser considerada complexa não lhe confere um status de superioridade frente a outra que não o é. Como bem destaca Jason Mittel, não podemos criar um juízo de valor a respeito do fato das narrativas complexas serem mais ricas e mais multifacetadas do que as tradicionais. O objetivo não é exaltar a superioridade de todo um modelo ou gênero narrativo. Ele, por exemplo, gosta até mais de série convencionais como Everybody Loves Raymond do que de 24 Horas, considerando a narrativa dessa última confusa conceitualmente e logicamente enlouquecedora. No entanto, percebe a complexidade narrativa como provedora de uma gama de oportunidades criativas e com uma forte perspectiva de retorno de público, quando este se interessa pela série, pois quer saber o que irá se suceder com os personagens e, para isso, não perderá nenhum episódio. (MITTEL, 2012)

Nem sempre também é fácil traçar uma linha que separe séries complexas de não complexas, no entanto, essa categoria nos permite perceber modos de narrar bastante populares entre as séries atuais e algumas dinâmicas que até algumas décadas atrás não eram tão comuns. 
Segundo Cássio Starling Carlos, crítico e pesquisador brasileiro, a complexidade é algo fácil de apontar, mas difícil de definir. Entretanto o autor considera que:

Para aqueles que assistem às séries com frequência, a complexidade é, provavelmente, a qualidade central que os leva a acompanhar cada desdobramento da trama, a se manterem fiéis e até preferirem ficar em casa vendo TV a ir ao cinema. Para quem começa a prestar atenção, a complexidade é o fator que fisga os olhos e a atenção, que causa surpresa a cada semana e que faz com que o mero interesse rapidamente se transforme em vício. (STARLING, 2006, p. 34)

Seria então a complexidade, além do gancho narrativo o que no faz querer devorar uma série? Antes de tentarmos entender os prazeres que a complexidade pode trazer para os espectadores, é preciso tentar defini-la e saber quais características podem distinguir uma narrativa complexa.

Em diferentes áreas do conhecimento, tais como a economia, a sociologia, as ciências sociais, a biologia, a física, as ciências da informação, entre outras, existe uma teoria chamada teoria da complexidade. Ela compreende uma visão holística sobre um sistema que abrange um grande número de componentes, cujas relações acarretam a criação de um sistema maior que a soma de suas partes. (VAROTSIS, 2013)

Para traduzirmos essa explicação de uma maneira mais ilustrativa, vamos nos afastar das narrativas e pensar em uma dinâmica entre jogadores de futebol. Se você tem um único jogador em cada campo, eles só podem chutar para gol e driblar um ao outro. Se você tem dois jogadores em cada, você acrescenta a isso a dinâmica do passe. Se você tem três jogadores, é possível ter também jogadas com triangulações. Quanto mais jogadores forem acrescentados em cada time, maiores são as possibilidades de relações. $\mathrm{O}$ fato de você acrescentar mais um jogador não o coloca apenas como mais um que faz exatamente o mesmo que o outro faria, esse acréscimo cria novas possibilidades de relações.

Aos sistemas complexos abertos podem ser acrescentados novos elementos que criam novas relações, assim o sistema vai se expandindo. Essa dinâmica é caracterizada como uma dinâmica não-linear. Pensar a narrativa segundo esses preceitos é se inspirar na complexidade como um pensamento metafórico, pois a narrativa é um modelo conceitual, e não físico. É possível pensar os personagens, suas motivações e ações como inputs do sistema: as interações dinâmicas desses 
elementos vão gerar histórias como resultado. As histórias abrangem uma quantidade de informação maior que a soma de seus inputs, ou seja, das informações que foram adicionadas no sistema individualmente como componentes da narrativa. (VAROTSIS, 2013)

Varotsis tem como interesse de pesquisa entender como é possível gerar narrativas com inteligência artificial. Nesse processo, ele analisa a construção de um universo com a inserção dos personagens, suas personalidades, características internas, conflitos externos (o que pode ser gerado a partir da relação entre qualquer número acima de dois personagens), cenários, eventos, objetivos dramáticos, etc. Qualquer acréscimo de um novo parâmetro cria um sistema mais complexo que o anterior, mas mesmo o que seria o sistema mais simples possível já poderia ser enquadrado como um sistema complexo. (VAROTSIS, 2013)

Uma das características principais dos sistemas holísticos é que cada componente afeta o outro de uma maneira multifacetada e multilinear, adicionando mais possibilidade de variação para o sistema como um todo. Os elementos não são independentes, eles se relacionam. (VAROTSIS, 2013)

Qual seria então o nível de complexidade da trama que levaria uma narrativa a merecer o atestado de narrativa complexa, se todas, em teoria, já possuem algum grau de complexidade?

Atentando para o quesito de não-linearidade do sistema complexo, poderíamos primeiramente ter em conta a relação temporal da narrativa complexa. A narrativa complexa promove um entrelaçamento entre tempos presente e passado(s), às vezes até futuro, do universo diegético.

Ricoeur considera que a narrativa imprime uma ordem à nossa experiência temporal (RICOEUR, 1994). Uma trama fora de ordem demanda maior empenho por parte do espectador que, para compreender a ação dramática, terá que reordenar todos os eventos em sua mente. As narrativas clássicas segundo a lógica aristotélica possuem começo, meio e fim, as ações dos personagens se desenvolvem de forma causal, uma ação levando a outra. Em outras palavras, a narrativa é formada por uma sequência cronológica de ações, em que o personagem precisa percorrer uma trajetória para alcançar seu objetivo, o que inclui compreender a moral que o faz evoluir. 
Podemos dividir a narrativa em três tempos. O primeiro é o tempo diegético, o qual é denominado story time. Este, em geral, como ocorre em nosso mundo, avança em progressão linear, de um momento para o momento seguinte, exceto quando os personagens viajam no tempo. O segundo tempo é o tempo do discurso (discourse time). Esse tempo corresponde à estrutura temporal e duração da narrativa que está sendo apresentada. Diferencia-se do story time pelas elipses, que pulam eventos que não são importantes para a história. É comum que as narrativas complexas reorganizem eventos, através de flashbacks que revelam eventos passados, repitam eventos narrativos em diferentes perspectivas e embaralhem cronologias. Há uma manipulação no tempo do discurso, ainda que seja assumido que os personagens vivenciem os eventos em uma progressão linear. Os enredos de mistério jogam com o tempo do discurso para criar suspenses relativos a eventos passados. O terceiro tempo é o tempo da narração, o momento em que se conta e se ouve a história. Mittel comenta que, diferentemente da literatura, em que o tempo da narração depende do ritmo do leitor, na TV e no cinema esse tempo é controlado e fixo, pois independente do tempo de intervalo que se demore para ver o conteúdo, o tempo de acesso ao conteúdo é o mesmo. O termo screen time, ou tempo de tela, pode ser melhor para designar o tempo de narração no audiovisual. (MITTEL, 2015)

Em artigo para a revista Anagrams, Heidi Piua e Letícia Affini comentam sobre tempo e estrutura da narrativa complexa, em seu estudo de caso da série How to get away with a murder. As autoras apoiam-se no conceito de narrativa complexa de Bordwell e Mittel, que diferem esse tipo de narrativa das tradicionais por sua complexidade estrutural e estilística. O tempo, apesar de largamente utilizado, não é o único elemento capaz de complexificar uma narrativa- A trama pode ser construída fora de ordem cronológica, mas o fio que conduz a ação dramática não é perdido, demandando, no entanto, que o público realize a atividade de costura. How to get away with a murder entrelaça vários saltos temporais, que vão revelando mais sobre os acontecimentos narrativos. Elas observam que alguns movimentos não lineares como prolepses (saltos temporais para frente), analepses (saltos temporais para trás), além de outras mudanças temporais, já estavam presentes na narrativa clássica. Daí concluem que a novidade trazida pelas narrativas complexas não está só nos jogos com a temporalidade, mas no somatório de vários efeitos. As 
tramas complexas provocam a desorientação temporária no espectador, exigindo um engajamento mais ativo para a compreensão da história. (PIUA, AFFINI, 2017)

As autoras identificam uma concepção emergente do tempo, a partir da relação entre narrativa complexa, seus antepassados modernistas e o desenvolvimento das TICs (tecnologias de informação e comunicação):

(...) enquanto alguns autores modernistas trabalhavam com a desintegração da forma com a qual vivenciamos o tempo, a narrativa complexa tende a efetuar, em diferentes graus, a recuperação do tempo. Enfatizam não apenas a fragmentação, como também a criação de ligações e vínculos entre os elementos fragmentados, o que amplia a possibilidade interpretativa. Se o Pós-modernismo trabalhou com a fragmentação do tempo, o sujeito da era digital possui a habilidade de ordenar as informações fragmentadas. (PIUA, AFFINI, 2017, p. 13-14)

O tempo da narrativa complexa é fragmentado, mas ela oferece recursos para que se reconstrua a ordem e a continuidade temporais. Convém destacar que o que estamos chamando de narrativa seriada complexa são séries onde se tem uma estrutura de narrativas múltiplas entrelaçadas (podendo envolver um único tempo ou diferentes tempos) e um grande número de personagens.

Starling aponta para, além do jogo das temporalidades, a extensão desse tipo de narrativa. O fato dela ser extensa permite que se desdobrem, recuem, se multipliquem e se repliquem, tanto as tramas narrativas quanto os personagens, os quais tem a oportunidade, por isso, de serem aprofundados. (STARLING, 2006)

Esse prolongamento da trama que, em geral, segue uma narrativa não teleológica tradicional, ou seja, em que não há uma relação direta de causa e efeito desenvolvida de forma linear, faz com que a qualquer momento novos eventos possam reconfigurar o sentido da história, o que ocorre, por exemplo, quando uma revelação de um evento passado cria um novo sentido para entendermos o presente:

As narrativas passam a ser cumulativas na medida em que fatos ocorridos em episódios precedentes não são esquecidos e podem ser retomados com a finalidade de dar uma nova luz sobre um tema ou assunto. Assim, personagens passam a ter memória e se ressentem de fatos ocorridos no passado ao mesmo tempo em que temem pelo seu futuro diante de uma determinada situação dramática que se relacione ao que viveram. (MUNGIOLI; PELEGRINI, 2013)

Para remontar a trama, o espectador precisa realizar uma espécie de quebracabeça interpretativo, reorganizar os eventos de uma maneira que faça sentido. Essa atitude exige uma participação mais ativa do público. A habilidade mental de 
reorganizar informações é importante para a resolução de problemas no mundo real. É uma capacidade cognitiva associada ao raciocínio espacial, ao mapeamento cognitivo e à atualização de modelos de situação, onde são operadas funções que envolvem revisão retroativa, rotação mental, deslocamento e reestruturação. Essas operações são usadas para construir narrativas que permitam a impressão de sentido, tanto na vida real quanto na ficção. (WILLEMSEN, 2018)

O ser humano busca lógica em nosso caótico cotidiano ou na complexidade de nossa mente, captando os fragmentos da condição humana. Isso se dá pela nossa capacidade mimética e é essa capacidade que permite conectarmos experiências e histórias dos outros com nossa história de vida e, dessa maneira, acharmos significado para elas.

Em nosso dia a dia, criamos narrativas que funcionam como ferramentas culturais e cognitivas para reduzirmos o senso de complexidade do mundo de excesso de informação que nos cerca. É assim que conseguimos filtrar e conectar informações relevantes sobre pessoas, eventos, locais, reais ou ficcionais, de modo a capturar essas experiências em nossa mente, estabelecer coerência e reduzir a ambiguidade, assim modelando a realidade de uma maneira compreensível para nós. Em outras palavras, as narrativas são a forma através da qual compreendemos o mundo, organizamos e memorizamos informações, conseguimos perceber as mudanças e continuidades, detectamos e criamos padrões de sentido, pensamos nossos objetivos e obstáculos, em cenários hipotéticos, alternativos e ficcionais, representamos e comunicamos a nossa experiência e entendemos as ações e processos mentais dos outros.

As narrativas complexas, de modo inverso, estrategicamente nos confundem, nos deixam perplexos e desestabilizados, nos fazendo sentir essa sensação de complexidade, já que não conseguimos juntar as partes e moldar uma realidade compreensível a partir delas. É como se a audiência ficasse em estado de quebra-cabeça mental insolúvel, ao menos momentaneamente. A complexidade então obstrui, de alguma forma, a habilidade interpretativa e de produção de sentido, o que encoraja o esforço de intensificar o processo ativo de reconfiguração da história, para tal fazendo uso de suas habilidades de resolução de problemas, memória, pensamento hipotético, aprendizado e de sua experiência. (WILLEMSEN, 2018) 
O pesquisador Willemsen prefere caracterizar a narrativa complexa pelo ponto de vista da recepção. Ele tenta entender a complexidade pelo ponto de vista da audiência, tendo em vista que características dessas narrativas complexas afetam a cognição. A complexidade seria então um efeito de percepção que emerge da dinâmica entre a estrutura narrativa da obra e as atividades de compreensão narrativa e de construção de sentido do público. Esse efeito de complexidade é percebido à medida que os espectadores se sentem desafiados a fazer uso de seus esforços cognitivos. Tentamos descobrir coerência, ordem e significado. (WILLEMSEN, 2018)

As narrativas complexas criam desafios cognitivos e o público responde a esses desafios trazendo o seu conhecimento para tirar sentido da experiência, que é um processo que se chama hermenêutica. Pela perspectiva hermenêutica, pensa-se como um indivíduo usa seu conhecimento sobre o mundo para criar sentido, em outras palavras, seu repertório. É preciso um balanço no nível de complexidade para que a atividade seja engajadora e não frustrante. (WILLEMSEN, 2018)

Entre os prazeres que provêm das narrativas teleológicas convencionais realistas estão a imersão, a identificação, a empatia, a emoção e a satisfação do desfecho. As narrativas complexas estimulam nossas faculdades perspectivas e cognitivas para provocar um maior engajamento. (WILLEMSEN, 2018)

Pensar a possibilidade de diferentes fechamentos nos encorajam a pensar em várias opções de interpretação. A interpretação se torna uma tarefa consciente e central, engajadora e gratificante conforme se vai conseguindo reconstituir a narrativa. A atividade interpretativa pode acontecer enquanto se vê a obra ou depois, inclusive trocando informações com outros fãs, revendo trechos. O paradoxo é que a atração não seria sentir a dissonância em si, mas o desafio de achar as respostas. Ter sucesso em vencer a dissonância é recompensador, porque faz com que o público se sinta competente e perspicaz. (WILLEMSEN, 2018)

Mittell considera o ato de amarrar fios narrativos desconectados como parte do prazer de assistir as narrativas. Há também o prazer de ser manipulado de maneira bem realizada até o momento da virada narrativa. Um exemplo, não de narrativa complexa, mas de uma manipulação bem feita é quando em Sexto sentido percebemos que na verdade o protagonista está morto. (MITTEL, 2010) 
Além do enredo há, nas narrativas complexas, uma dimensão autorreferencial e estrutural, e passa a ser interessante perceber os mecanismos usados pelos autores para produzir:

(...) universos narrativos mais complexos, que exigem dos telespectadores um envolvimento emocional e cognitivo mais apurado tanto em função do uso de diferentes temporalidades como em função de uma maior complexidade na construção de personagens e, portanto, de suas motivações e relações com outros personagens. Cabe destacar, no entanto, que esse envolvimento possui relação entre o prazer de conhecer, de desvendar, de vislumbrar, além da história, a própria construção textual e de reconhecê-la como um ato de criatividade que extrapola os limites do já-visto e do já-dito. O telespectador transforma-se em descobridor, alguém que procura "prestar mais atenção às estruturas e aos significados das cenas, pois a qualquer momento uma leitura de segundo nível poderá ser necessária" (MOTTER e MUNGIOLI, 2006). Une-se o prazer de conhecer, reconhecer, descobrir os segredos - ou seja, a epistemofilia (CULLER, 2009) - ao prazer de se descobrirem os mecanismos que envolvem esses segredos, o que garante ao telespectador o status de connaisseurs. (MUNGIOLI; PELEGRINI, 2013)

Segundo Edward L. Devo e Richard M. Ryan temos necessidades intrínsecas psicológicas de autonomia, competência e relacionamento social. Estas estariam sendo satisfeitas por uma experiência bem-sucedida de ver uma narrativa complexa. A pessoa a assiste porque quer, tem competência em decifrá-la e pode se sentir conectada aos outros ao trocar informações sobre a trama para criar sentido. (DEVO; RYAN apud WILLEMSEN, 2018)

As narrativas complexas apresentam dissonâncias, como paradoxos e ambiguidades, enredos com excesso de estímulos, multiplicação de personagens e incongruências narrativas e cognitivas, além de outras dificuldades para se fechar um sentido interpretativo.

As dissonâncias estimulam os espectadores a se engajarem em várias operações de interpretação e também podem ser interessantes para quebrar a naturalidade com a qual embarcamos nas histórias. Os espectadores usam seu repertório de vida e de experiência artística como estratégia interpretativa. No caso de The Affair, por exemplo, a dissonância é mantida: vemos os relatos de cada personagem onde as incongruências não são resolvidas, e não se pretende resolvêlas, uma vez que essa impossibilidade de conseguir uma história única por si só comunica uma mensagem sobre o nosso mundo, de que a realidade é na verdade uma interpretação e isso ainda pode despertar uma dimensão reflexiva. 
Willemsen organiza uma listagem com alguns elementos presentes nas narrativas complexas (WILLEMSEN, 2018):

- Experimentações temporais: organização de eventos em ordem não cronológica, narração reversa (começa com o final e vai até o início), múltiplas linhas temporais, fragmentação espaço-temporal;

- Narração: lacunas ou sobrecargas de informações consideráveis, incongruências, ambiguidades;

- Foco: não confiabilidade, enfoque no interior (ou poderíamos dizer subjetividade), mudanças de focalização ocultas e realismo subjetivo não demarcado;

- Continuidade dos personagens: personalidades divididas, duplas ou sócias, personagens que veem a si mesmos como múltiplo(s) (alteregos, eu-fragmentários)

- Espaços e mundos imaginários complexos: múltiplos, universos multidimensionais ou paralelos, universos impossíveis, metalepses ontológicas (como Inception, em que dentro de um mundo aparentemente real existem várias camadas de mundos dos sonhos)

Convém lembrar que essas características narrativas não são novas, estão presentes em muitos filmes e na literatura, dos quais as narrativas complexas que apareceram na década de 1990 são tributárias, mais especialmente dos filmes de arte dos anos 1930, dos modernistas dos anos 1950, 1960 e 1970 e dos film noir de 1940. (WILLEMSEN, 2018)

O que podemos caracterizar como narrativas complexas são então aquelas que desafiam a compreensão; criam desorientação; exijem um excesso de esforço cognitivo pelo grande número de informações: muitos eventos, muitos personagens, muitas relações entre eles; possuem contradições ou informações não confiáveis; ou estruturas narrativas complicadas, tais como universos paralelos, caminhos bifurcados com realidades alternativas, entre outras.

Em narrativas não-lineares, as idas e vindas temporais podem trazer para a história revelações de eventos passados que, de alguma maneira, reconfigurem o tempo presente ou a maneira de olharmos para os personagens e situações. 
Em Dark, por exemplo, que é uma série que entrelaça diferentes temporalidades dos personagens (que são representados por diferentes atores) com viagens no tempo, pode se chegar a uma situação em que o filho de um personagem de um ano avançado pode ter viajado no tempo e ser pai de outro, que nasceu décadas antes dele. Além disso, não temos claro quem é o "bem" e quem é o "mal", fugindo às narrativas maniqueístas. A narrativa se torna um terreno mais sinuoso, onde novas revelações podem vir de qualquer lugar: nada pode ser tido como um ponto certo ou definido.

Starling acredita que o público respondeu à complexificação das séries, dedicando cada vez mais horas a acompanhá-las. (STARLING, 2006)

Outra característica das narrativas complexas, citada por Mittel, é a hibridização da forma episódica com a contínua (MITTEL, 2015). A primeira garante a recompensa das resoluções pontuais do episódio, enquanto a segunda possibilita o desenvolvimento de uma trama mais complexa e que deixa mistérios em suspenso.

As pesquisadoras Juara Castro Conceição e Rosana Maria Borges também relacionam narrativas complexas às narrativas híbridas e inovadoras, mas enfocam a aproximação da linguagem da série à do cinema. Outro fator destacado por elas é a valorização exponencial dos personagens, quase nenhum (ou nenhum) é coadjuvante. (CONCEIÇÃO; BORGES, 2017)

Em comum, todas essas séries têm uma grande ênfase nos personagens. Em narrativas serializadas, os personagens ganham a possibilidade de se desenvolver mais, de revelar facetas surpreendentes e de aprender com o vivido nas situações pelas quais passam na trama, podendo se tornar mais complexos. (STARLING, 2006)

Narrativas complexas requerem personagens tridimensionais. Esse termo foi popularizado pelo húngaro Lajos Egri em seu livro The art of dramatic writting, que, ao contrário da maioria dos livros de dramaturgia da época, propunha a formulação de uma estrutura narrativa que partisse dos personagens, desafiando a "lei" de Aristóteles, de que estes deveriam satisfazer as exigências da trama. Isso tornou-se possível em seu contexto histórico, no qual o oráculo de Delfos e o poder do destino foram substituídos pela ascensão da burguesia na sociedade ocidental, 
que enriqueceu pelo próprio esforço, conforme preconiza a ética protestante, passando a carregar consigo a crença no poder do indivíduo como agente decisivo dos acontecimentos. Assim era possível que Egri, como outros dramaturgos europeus do século 19, Ibsen, Steinberg e Tchekhov, trabalhasse suas peças a partir da formulação do perfil dos personagens. (MACIEL, 2003)

Segundo Egri os personagens possuem três dimensões: a física (idade, sexo, altura, peso, cor de pele, cor dos olhos, etc), a social (profissão, educação, vida social, posição na comunidade, opinião política, etc) e a psicológica (premissa pessoal, projetos, moral, conduta, etc). Luiz Carlos Maciel, em seu livro $O$ poder do clímax, destaca que o autor e roteirista Robert Mckee considera que, ainda que relevantes para a profundidade e criação de camadas dos personagens, essas dimensões são elementos de caracterização, mas não o princípio fundamental dos personagens. Este corresponderia às suas decisões, às opções que os personagens fazem diante de sua "liberdade de escolha". Acrescenta que a força que determina as escolhas é a vontade, pois as pessoas agem mais segundo a vontade do que segundo a razão. E são as decisões tomadas pelos personagens que empurram a trama para frente e provocam os acontecimentos decisivos. É diante de suas opções que conhecemos o personagem. Quanto maior a pressão na escolha, mais verdadeira e profunda é o que ela revela. (MACIEL, 2003)

Maciel considera que tanto faz partir do enredo quanto dos personagens, que esses são dois caminhos distintos, porém possíveis, para a criação narrativa. (MACIEL, 2003) Mas a visão que coloca os personagens como agentes é uma visão mais subjetiva, que permite que possamos pensar narrativas com múltiplas perspectivas.

Falamos muito sobre a criação de embates entre perspectivas, mas essa não é a única questão que envolve uma narrativa que abrange mais de um ponto de vista. Skam, por exemplo, não cria embates entre as perspectivas, mas os deslocamentos proporcionados pela mudança do protagonismo a cada temporada permitem um melhor entendimento dos personagens, conhecendo seus objetivos, dilemas, segredos e sonhos. Somos capazes de ir mais fundo na subjetividade dos personagens, entendendo por que e como ele age. 
Em suma, o objetivo principal dessa tese é compreender melhor a questão da variação dos pontos de vista como uma ferramenta para ser usada na construção de narrativas seriadas, sejam elas audiovisuais ou transmídia.

A pergunta que fica lançada para reflexão é se pessoas que crescerem com esse tipo de narrativa que fragmenta e relativiza a verdade serão pessoas que poderão incorporar em suas vidas essa forma de ver o mundo.

A resposta pode ser positiva se pensarmos que é a partir da narrativa que organizamos o caos de informação do mundo que nos cerca. Se estivermos familiarizados com outras formas de narrar, talvez possamos aplicar essas matrizes à nossa própria vida e, assim, ter visões mais plurais. 


\section{Ficção seriada}

\subsection{Uma narrativa em fatias}

A ficção seriada é uma narrativa produzida e consumida em pedaços, fatias, doses homeopáticas (BORELLI, 1996), ainda que possa também ser consumida compulsivamente, quando já se possui o acesso a todas as suas fatias.

Para pensar nos laços que a ficção seriada audiovisual estabelece com seu público, em paralelo a um bom filme, gosto de pensar nas seguintes imagens. Imagine que o filme e a série são pessoas. Um bom filme seria aquela pessoa que você conhece em uma viagem e passa um momento incrível, que pode até te marcar para o resto da vida, ainda que você nunca mais torne a ver essa pessoa. A ficção seriada seria alguém que aparece na sua vida e está lá cotidianamente se relacionando com você, aos poucos conquistando um espaço frequente. De repente, você se dá conta do quão importante ele é para você, já se tornou um amigo. Isso ocorre com os personagens de suas séries favoritas: você começa a se preocupar com eles como se preocupa com seus amigos.

Esse poder da ficção seriada não se restringe ao âmbito audiovisual, estando também presente na literatura e na transmídia. Que fã de Harry Potter não aguardou ansioso pelo lançamento de um novo livro? Quantos fãs da série transmídia Skam não ficaram atualizando o feed $^{12}$ correspondente ao celular de Noora para saber se o seu namorado já havia lhe mandado alguma notícia quando sumiu?

Ao acompanhar suas vidas, ainda que ficcionais, estes personagens se tornam importantes para nós. Grande parte dos romances de Charles Dickens que conhecemos hoje como livros, foram inicialmente divididos em capítulos, que eram publicados semanalmente nos jornais, formato conhecido como folhetim. O escritor inglês, em geral, escrevia suas publicações com duas semanas em avanço. Logo, recebia o feedback do público, que podia levar em consideração para alterar sua narrativa ou não. Não havia internet, mas havia sessão de cartas no jornal e Dickens encontrava seu público pelas ruas. A internet potencializa a troca entre público e autor, mas temos que lembrar que esse fenômeno é anterior à era digital. Dickens

\footnotetext{
${ }^{12}$ Feed significa alimentação, que no meio da internet corresponde a postagem de dados. É uma "lista" de informação (pode ser composta por imagens, textos, matérias, etc) que reúne os últimos conteúdos postados por usuários ou sites que você segue.
} 
escreveu um folhetim chamado The Old Curiosity Shop. Ao passo que seu fim se aproximava, ficou aparente que a querida órfã Nell Trent ia morrer. Enquanto o suspense crescia, os leitores suplicavam para que o autor a deixasse viver. O pesquisador Frank Rose conta que a tripulação de um navio inglês, ao chegar ao porto de Nova York, gritava de ansiedade para saber se Nell havia morrido e quando lhes responderam que sim, foi um momento de grande histeria. (ROSE, 2012)

Essa mistura de ficção e realidade, propiciada pela serialidade, já foi alvo de muitos preconceitos e críticas. Já antes da serialização televisiva, os folhetins eram tidos como altamente perigosos, pois diferentemente dos livros que eram lidos nas horas de ócio, estes eram consumidos semanalmente, misturando-se com as atividades diárias, podendo ser altamente prejudiciais para o cotidiano de trabalho. Curioso o fato de que o mais temido era a capacidade imersiva da narrativa seriada, justo o que é muitas vezes buscado nas experiências atuais: envolver o usuário.

A serialização na literatura antecede o folhetim, tendo estado presente nas formas epistolares, como cartas e sermões, além de nas narrativas míticas intermináveis como As mil e uma noites. Mas foi com o folhetim que sua técnica mais se desenvolveu, influenciando posteriormente o radiodrama e a radionovela, além do cinema exibido em fragmentos. (MACHADO, 2000)

O folhetim surgiu na França, no século XIX, momento de proliferação dos jornais devido à evolução dos sistemas de impressão. Na verdade, folhetim era o nome dado à área de rodapé do jornal, onde eram publicadas variedades, entre elas, o romance partilhado em capítulos. O sucesso dessa forma foi tal que as pessoas compravam o jornal para saber como a história continuava, assim essa forma de narrar ganhou o nome da sessão.

Para despertar o desejo de leitura do próximo capítulo, teve que se desenvolver a técnica do gancho narrativo, o qual alimenta a curiosidade sobre o enigma, motivando o leitor a querer saber mais sobre a história (FIGUEIREDO, 2010). Tecnicamente, as informações de uma história são partilhadas em fragmentos, que são conectados por esses ganchos narrativos.

$\mathrm{O}$ advento da publicação dos romances em jornal também contribuiu para o alargamento do público, devido à redução do custo da obra. Uma das características desse tipo de estrutura é que ela abre espaço para o estabelecimento de uma relação 
entre autor e audiência, como vimos no caso de Dickens. Ainda que no caso que relatamos ele não tenha atendido aos anseios do público, em outros momentos chegou a mudar o rumo das histórias, e até o país que servia como cenário à trama, a fim de manter seu público interessado. (ROSE, 2012)

Segundo Martín-Barbero, na "literatura popular" a preocupação com o feedback do público antecede o folhetim. Ele cita o Cordel, na Espanha e a Colportage, na França, o primeiro mais dirigido à população urbana e o segundo à camponesa. Sua escrita tinha uma semelhança com a estrutura oral, boa parte apresentada em verso, e sociologicamente destinada a ser lida em voz alta e coletivamente. Diferenciando-se do livro e assemelhando-se ao periódico, buscava seus leitores na rua, através de folhetos, que tinham uma gravura na capa. Não haviam sido originalmente escritos para o público popular, ao qual se destinavam, mas tinham sua produção orientada pelo retorno que seus vendedores ambulantes lhe davam e, em alguns casos, os próprios trabalhadores que faziam as impressões interferiam nas escolhas e adaptavam os textos.

Já o folhetim era composto por textos originais, escritos diretamente para o público popular, tendo, assim, sua temática escolhida de modo a se adequar ao gosto desses consumidores. A fragmentação da leitura permitia também que fosse lido com frequência, mas em uma quantidade de texto que o povo, que não tinha um hábito tão grande de leitura, poderia enquadrar em seu cotidiano. A periodicidade semanal e o custo também condiziam com seu salário. Martín-Barbero acredita que a possibilidade do envio de cartas e a, pelo menos aparente, potencialidade de intervenção na narrativa fizeram parte da dinâmica que lhe permitiu tanto sucesso. As novelas latino-americanas até hoje fazem uso desse modelo. (MARTÍNBARBERO, 2008)

Arlindo Machado defende que foi o cinema que forneceu o modelo básico de serialização audiovisual de que se vale hoje a televisão. No cinema, a serialização começou com os nickelodeons, que eram salas populares, cuja entrada custava apenas um níquel. Em 1913, quando foi ampliada a oferta de longas metragens, estes foram divididos em pequenas partes para serem exibidas em diferentes sessões nessas salas, uma vez que não havia muito conforto, ficando as pessoas em pé ou em bancos de madeira sem encosto. Os longas eram, na verdade, dirigidos aos salões de cinema que surgiam, mas estes, além de pouco numerosos, 
caros e restritos a lugares mais centrais, eram acessíveis apenas à classe média das grandes cidades. Assim, a opção de que fossem exibidos nos nickelodeons permitia que o público fosse ampliado.

A TV aproveitou esse modelo de narrativa, com episódios curtos, a fim de evitar que a atenção do público fosse perdida para suas tarefas diárias. Os pequenos aparelhos de TV localizavam-se, em geral, no meio das salas de estar, estando em um ambiente iluminado e com muitas distrações, assim a atenção do espectador era desviada com frequência. (MACHADO, 2000)

Machado acrescenta que o break surgiu provavelmente por razões econômicas, impostas pelas necessidades de financiamento na televisão comercial, mas teve um papel também organizativo ao propiciar um momento de "respiração" e absorver a dispersão e ganchos de tensão, despertando o interesse da audiência no modelo corte-suspense.

\begin{abstract}
Seccionando o relato no momento preciso em que se forma uma tensão e em que o espectador mais quer a continuação ou o desfecho, a programação de televisão excita a imaginação do público. Assim, o corte e o suspense emocional abrem brechas para participação do espectador, convidando-o a prever o posterior desenvolvimento do entrecho. (MACHADO, 2000, p. 88)
\end{abstract}

Em seu livro, publicado em 2000, Machado argumenta que se os intervalos fossem suprimidos o interesse do programa cairia de imediato. (MACHADO, 2000) Mas com a Netflix vimos que isso não ocorre de fato. O break pode ampliar a expectativa, mas quem motiva a visão de mais um capítulo são os ganchos narrativos. Somos capazes de fazer bingewatching, até devorar uma série em um único fim de semana, criando apenas breaks para necessidades básicas. Acredito que o fato de podermos criar nosso próprio break, e de assistirmos o conteúdo onde e quando queremos, propicia também que possamos dar mais atenção a ele, desde que, é claro, o destaquemos como algo digno desse merecimento, em um cenário de excesso de informação.

Convém destacar que os breaks comerciais também tinham razões produtivas na TV gravada ao vivo. Nas sitcoms $^{13}$, por exemplo, o break servia para

\footnotetext{
${ }^{13}$ Sitcom, abreviatura do inglês situation comedy, que significa comédia de situação. Formada por um conjunto fixo de personagens e cenários. Em geral, são comédias para serem vistas em momentos cotidianos de descompressão, muitas vezes em família. Costumam reafirmar valores da classe média americana. Por conta de sua estrutura, que tem os personagens como um forte alicerce, a conexão entre eles e o público é decisiva para o sucesso de uma sitcom.
} 
uma mudança de cena, em especial para girar o cenário, ou seja, serviam à uma questão prática que cumpria uma necessidade narrativa.

E se, antes, as séries foram consideradas ideais para a TV por conta da dispersão, hoje, com o público tendo mais controle sobre o que assiste, desconfio que o motivo para o sucesso do formato na TV atual seja, justamente, o envolvimento que a série permite com os personagens e a narrativa. A série garante que um público envolvido com os dilemas de determinados personagens, volte para ver o que se sucede, que queira saber o desfecho do gancho deixado pela trama. Isso é interessante comercialmente para as emissoras, ainda mais em um cenário em que a oferta de conteúdo é absurdamente maior que a capacidade de consumo das pessoas.

Scolari conta que a TV se instalou na Europa como um meio unidirecional a serviço do Estado, enquanto nos Estados Unidos sempre teve intuitos comerciais. Porém, nos anos 80, os monopólios estatais europeus tiveram que compartilhar seus espaços com canais privados, multiplicando-se a oferta de canais. Isso ampliou a segmentação da audiência e trouxe novas formas de consumo. $\mathrm{O}$ autor cita Umberto Eco, evocando a denominação que este deu para essa transformação como a mudança da paleotelevisão para a neotelevisão. Sem querer entrar em muitos detalhes quanto a essas denominações, as mudanças básicas destacadas foram a diminuição da oposição entre entretenimento e informação e o fato da TV, mais que apresentar a realidade, passar a construí-la. Na dita neotelevisão, entretenimento (ficção) e informação (realidade) se mesclam em diferentes gradações, de acordo com o programa, as diferenças culturais são reduzidas e ela é bastante autoreferencial, ou seja, fala sobre si mesma e abre ao público os dispositivos técnicos da enunciação: microfones, câmeras, salas de redações dos jornais. (SCOLARI, 2009)

Ainda que diga que não podemos reduzir a televisão a uma sucessão de etapas, a não ser por objetivos didáticos, Scolari cita a hipertelevisão como o que veio depois da neotelevisão. Sobre suas características, ele enumera a complexificação das séries de TV: multiplicação dos personagens, sendo às vezes até difícil identificar o protagonista, ou mesmo quando se sabe quem é o principal, os personagens secundários têm um papel tão relevante que o título de secundários nem seria capaz de representá-los devidamente. Todos têm desejos, objetivos e 
sofrem, lidam com oponentes e ajudantes, superam desafios e põem em prática suas competências. (SCOLARI, 2009)

Faremos um breve percurso sobre a história da TV no que tange as séries audiovisuais para entender do que se trata o conceito série e como foram sendo constituídas as séries de ficção até chegarmos nas narrativas denominadas complexas e nas séries transmídia, categorias nas quais podemos enquadrar nossos objetos de estudo.

\subsection{A ficção seriada televisiva como campo de estudo}

A formação de um campo de estudos sobre narrativas seriadas televisuais é relativamente recente. Muitos autores devem a isso o fato de que a TV, até pouco tempo atrás, era vista como uma "arte menor". A maior parte dos autores estudados cita uns aos outros e, aparentemente, tiveram a mesma bibliografia como base. Grande parte dos estudos iniciais de TV centrou-se sobre sua qualidade e seu modo produtivo.

A necessidade de alimentar com material audiovisual uma programação ininterrupta de televisão fez com que fossem desenvolvidos métodos de produção em larga escala, que simplificassem o trabalho e fossem rentáveis. (MACHADO, 2000) (BALOGH, 2002) Segundo Anna Maria Balogh, esse modelo de produção era tido como nutrindo uma perturbadora similaridade com a produção em série da indústria e, assim, a visão negativa que se tem de produção em série, em geral, se estendeu à serialidade da TV. (BALOGH, 2002)

A grande crítica que pairou sobre as produções culturais seriadas foi, então, a forma baseada em modelos estruturais que eram acusados de contar a mesma história repetidamente, mas de maneira camuflada, o que a tornava, desse modo, ainda pior que a produção em série da indústria, pois esta, pelo menos, não escondia o fato de produzir modelo repetitivos.

Os críticos da cultura de massa, sobretudo os da Escola de Frankfurt, recriminavam as produções para uma audiência massiva e em série, devido à sua homogeneização, que fazia com que perdessem os elementos fundamentais das obras de arte: a autenticidade e a originalidade. (CASTELLANO; MEIMARIDIS, 2018) 
Umberto Eco é um dos autores que aborda essa questão, tentando, em um primeiro momento, defender a originalidade presente na repetição, mas depois considera a possibilidade de outros parâmetros serem mais relevantes do que o caráter de originalidade para valorar a produção seriada. (ECO, 1989)

O autor observa que muitas outras artes são também seriais. Para ele:

o conceito de originalidade absoluta, em relação a obras anteriores e às próprias regras do gênero, é um conceito contemporâneo, nascido com o romantismo; a arte clássica era amplamente serial e as vanguardas históricas, de vários modos, deixaram em crise a ideia romântica da criação como estreia no absoluto. (ECO, 1989, p.133)

Defende ainda que, de todo modo, a série não se opõe, necessariamente, à inovação e que a estrutura não a torna banal e limitada. Cita que a arte moderna produziu obras originais usando elementos pré-fabricados em série e que, na arquitetura e na poesia tradicional, o fato de haver esquemas predeterminados para serem seguidos não impediu a inovação ou a invenção. (ECO, 1989)

Considera que pode ser justamente o fato da série repetir o que já conhecemos que, de algum modo, nos interesse e console, ao temos a sensação de poder prever o desenrolar narrativo:

Na série, o leitor acredita que desfruta da novidade da história enquanto, de fato, distrai-se seguindo um esquema narrativo constante e fica satisfeito ao encontrar um personagem conhecido, com seus tiques, suas frases feitas, suas técnicas para solucionar problemas... A série neste sentido responde à necessidade infantil, mas nem por isso doentia, de ouvir sempre a mesma história, de consolar-se com o retorno do idêntico, superficialmente marcado. (ECO, 1989, p.123)

François Jost, em contraponto a esse argumento, compreende que a importância das séries nas práticas culturais tem menos a ver com sua anatomia e mais com as relações que estabelecem com seus espectadores. Em seus estudos, objetiva entender o sucesso das séries norte-americanas e considera que o ritmo dos episódios, regras de roteiro e procedimentos visuais arquitetados com minúcia, por si só, não explicam a paixão que estas despertam em seus fãs. A paixão estaria mais ligada às relações simbólicas desenvolvidas ao passo que o espectador encontra nos personagens conflitos semelhantes aos seus. Mas, por hora, vamos nos manter nas questões formais. (JOST, 2012) 
Tanto Anna Maria Balogh, quanto Arlindo Machado citam Lorenzo Vilches para definir a ficção seriada televisiva como baseada em uma alternância desigual, onde cada nova série (Machado usa a palavra episódio) se utiliza de um conjunto de elementos que já são conhecidos pelo espectador, em maior número, e de alguns elementos novos, em menor proporção, e que a maioria das séries tradicionais possuem estruturas narrativas simples e previsíveis, que poderiam ser enquadradas nos modelos de Propp ou Bremond. (VILCHES, 1984 apud BALOGH, 2002; MACHADO, 2000) Convém lembrar que não são só essas séries televisivas tradicionais, às quais os autores se referem, que podem ser enquadradas nesses modelos, mas também muitos filmes e outros tipos de narrativas não seriadas. Por outro lado, as séries televisivas complexas podem não corresponder a essas observações.

Machado considera que nas séries:

o enredo é geralmente estruturado sob a forma de capítulos ou episódios, cada um deles apresentado em dia e horário diferente e subdividido, por sua vez, em blocos menores, separados uns dos outros por breaks para a entrada de comerciais ou de chamadas para outros programas. (MACHADO, 2000, p.83)

Acrescenta que, muitas vezes, o bloco apresenta uma contextualização no início, para refrescar a memória, e um gancho de tensão no final, para fazer com que o espectador se interesse em voltar a ver a série que, por isso, muitas vezes acaba justamente no momento mais inquietante.

Percebemos que hoje há muitas narrativas seriadas que não fazem essa contextualização de início, em parte pelo fato de imaginarem que o consumo dos episódios foi feito em um curto intervalo de tempo ou que se a audiência tiver dúvidas pode facilmente buscar na internet o que aconteceu ou mesmo rever o episódio anterior. É interessante também notar que a definição de Machado, feita já no ano 2000, tem em vista a forma como a série costumava ser veiculada e assistida. Vinte anos depois, em um tempo pós streaming, já não poderíamos definir a série da mesma forma, ainda que esta ainda seja uma das formas de espectatorialidade, não é a única.

Segundo Balogh, no início da TV, as narrativas seriadas eram veiculadas de uma a duas vezes por semana e chamadas "seriados". Afirma que, com a TV por assinatura, houve o deslocamento de programas nas grades horárias e, 
consequentemente, de seu público, passando as narrativas a ter a denominação genérica de "séries", e tanto as novas quanto as antigas começaram a figurar em conjunto na programação. (BALOGH, 2002) Esse deslocamento de programas não parece ser a motivação para uma mudança de nomenclatura. As palavras série e seriado ainda podem gerar controvérsias, tanto para pesquisadores quanto para o senso comum. São muitas vezes utilizadas como sinônimo. Alguns consideram que a série demanda um consumo em sequência, enquanto o seriado pode ter um consumo mais independente. Não há consenso sobre as terminologias talvez, em parte, pelas próprias evoluções que o gênero vem sofrendo e que alteram as suas características.

Para Jost, algumas décadas atrás existia uma diferença radical entre séries e novelas, as primeiras com episódios fechados unitários e as segundas com episódios que continuavam. Atualmente muitas séries são novelescas e mesmo quando os episódios são fechados os personagens evoluem ao longo da narrativa. (JOST, 2012)

Isso faz com que tanto a série quanto a novela possam ter características de saga. No entanto, Eco vê a saga, como uma experiência a parte da série, considerando que esta tem episódios fechados enquanto a saga é constituída por uma sucessão de eventos, aparentemente sempre novos, que se ligam, formando uma espécie de genealogia do personagem que pode ser acompanhado do nascimento à morte (podendo também continuar com seus descendentes e afins). $(\mathrm{ECO}, 1989)$

Eco destaca, entre outras variantes das séries, a estrutura em flashback ou loop, onde personagens, como ocorre com o Superman, não são seguidos no curso de uma existência. Ficam sendo revisitados para lançar novas histórias, em geral por razões comerciais. O personagem não envelhece, "tem pouco futuro, mas tem um passado enorme, e, todavia, nada do seu passado jamais deverá alterar o seu presente mitológico que foi apresentado ao leitor desde o início." (ECO, 1989, p. 124)

A lógica mainstream hoje já segue uma direção distinta, onde constantemente o passado vai sendo revelado à medida que se constrói o futuro. 
Balogh trata as séries como tendo níveis e elementos de repetição diferentes, mas com características estruturais de gênero se repetindo com frequência. (BALOGH, 2002)

Ela destaca as tipologias mais famosas de séries televisivas: o western, com variações locais, como o cangaço; policiais; ficção científica, do fantástico ao realismo mágico; comédias (conhecidas pela abreviação sitcom de situation comedies; séries infantis (muitas sendo aventuras); tragédia (poucas); e soap operas ou telenovelas (para ela, as soap operas continuariam sendo dedicadas especialmente às donas de casa e as telenovelas teriam um público mais amplo).

Balogh diz que, para conhecermos uma série, temos que segmentá-la e decupar suas variáveis e invariáveis. Baseia-se no autor Omar Calabrese (também citado por Machado) para pensar a estética da repetição em três níveis: figurativo (características dos personagens ou da imagens, como os olhos azuis do protagonista, o avião mostrado em voo como um pássaro); estático (pode haver uma disputa de bem versus mal e o bem sempre vencer) e dinâmico (tipos de cenas que se repetem). (BALOGH, 2002)

A série Hill Street Blues é tida como a responsável pela introdução na televisão da estrutura de narrativas múltiplas entrelaçadas e um grande número de personagens. Mesclava histórias mais curtas, que se encerravam em um único episódio com outras mais longas, que podiam durar por vários episódios ou mesmo temporadas. Cada episódio mostrava a rotina de um dia da delegacia local do bairro Hill Street. (MACHADO, 2000)

Como uma tendência das séries atuais, Machado aponta o "entrelaçamento de um enorme número de situações paralelas ou divergentes, gerando como resultado uma complexa trama de acontecimentos não necessariamente integrados." (MACHADO, 2000, p. 94) Lembra que esse modo de engendramento narrativo também pode ser encontrado na literatura e no cinema, mas que ele floresceu com a TV, possivelmente tendo em vista a longa duração dos programas. Também comenta que a curta diferença de tempo entre produção e recepção torna possível atender as demandas da audiência. 


\subsection{Breve histórico da ficção seriada audiovisual}

Agora vamos olhar para a origem das séries de TV e suas transformações ao longo do tempo até chegar nas narrativas complexas. Não tenho como objetivo fazer nenhuma análise histórica aprofundada, pois foge ao escopo desta tese. No entanto, considero importante levantar alguns marcos da história da ficção seriada, para que possamos compreender melhor o cenário hoje.

O recorte histórico realizado está centrado na produção norte-americana, pelo fato de ter sido o berço do surgimento das séries de TV, desenvolvendo os modelos que irão influenciar grande parte da produção seriada de outros países. Ainda que os processos de desenvolvimento da TV em cada país tenham suas particularidades, há traços desenvolvidos nos primórdios da produção televisiva norte-americana que se mantém até hoje.

A tecnologia da TV surgiu na década de 1920, contudo ela só se tornou um meio de comunicação massivo após a segunda guerra mundial, quando as grandes redes de TV norte-americanas começaram a investir em sua expansão comercial. (CASTELLANO; MEIMARIDIS, 2018) O Brasil teve o lançamento de sua primeira rede de TV apenas 8 anos após a primeira rede norte-americana. Assis Chateaubriand (Chatô), no fim da década de 1940, encomendou dos Estados Unidos tanto os aparelhos quanto os técnicos que os instalaram, a fim de montar a TV Tupi, inaugurada em 1950. Ele não se preocupou se havia ou não público na época ou se os aparelhos eram raros e caros. Ele quis ser pioneiro, chegando ele próprio a importar aparelhos, já que sem eles não seria possível alguém assistir sua programação. Devido à produção nacional do aparelho de TV Invictus, que permitiu já em 1951 a emissão e o sucesso da primeira telenovela Sua vida me pertence, de Walter Foster, e ao momento próspero para os fazendeiros de café do Estado de São Paulo, o mercado brasileiro acabou crescendo rapidamente. (CURI, 2015)

Chatô foi influenciado não só pela tecnologia norte-americana, como também por seu conteúdo, dado que fortalece a importância do recorte, até para a compreensão histórica da produção nacional, embora esse objeto também fuja ao escopo desse trabalho.

Diferentes autores traçam tipificações, dividindo os eventos históricos como eras. Ainda que nenhumas dessas divisões possam abranger toda a complexidade 
histórica das transformações da TV, e tampouco ter em conta as semelhanças e diferenças do que ocorreu nos diferentes países, vamos nos utilizar didaticamente da divisão proposta por Mittel (2010), relacionando o que foi destacado por outros autores, em cada uma dessas "eras".

\section{Era clássica das redes}

A primeira "era" seria a Era clássica das redes, que começa nos Estados Unidos na década de 1940. O cenário era constituído por quatro grandes redes ABC, CBS, NBC e DuMont (A DuMont esteve em cena até 1955). A diferença da classificação de Mittel para outros autores é que ele considera que essa "era" vai até a entrada do cabo, nos anos de 1980, enquanto outros autores segmentam mais esse período, criando um novo marco para o momento de entrada no mercado de outras redes independentes. Para estes autores, o primeiro momento em que as emissoras reinavam soberanas é designado Idade do Ouro. Nesse período, os anunciantes sustentavam financeiramente a produção, em geral, produziam em seus próprios estúdios em Nova York os produtos televisivos, que depois eram negociados para serem exibidos nas redes, ou seja, às emissoras cabia a distribuição. (ESQUENAZI, 2010)

Após ter comprado um aparelho de TV, a audiência tinha a percepção do meio como exibidor de produtos gratuitos. Eram bem tolerantes ao conteúdo e acríticos. Com o passar do tempo, o público foi se tornando mais exigente quanto à programação e foram sendo desenvolvidos os sistemas de medição de audiência (respectivamente, início e fim dos anos 1960 nos Estados Unidos e no Brasil). Fato comum em toda essa "era" foi a produção de programas em massa, transmitidos simultaneamente para todo o país. (CURI, 2015)

O meio bebeu muito da experiência do rádio e muitos programas surgiram de adaptações de um meio para o outro, tais como dramas e comédias de ficção, teatro, filmes, eventos esportivos, programas de variedades e gincanas. Um fator que contribui para essa adaptação da programação, de um meio para o outro, foi que os donos das redes de TV, eram, em geral, os mesmos donos das redes de radio, assim essa migração lhes parecia um movimento seguro. (STARLING, 2006) 
Diferentemente do que já ocorria no rádio, no início da TV ainda não havia a tecnologia de gravação dos programas, assim eles tinham que ser ao vivo. Em termos de ficção, o modelo mais usual era, então, o teleteatro, peças de teatro filmadas e transmitidas ao vivo.

O financiamento da produção se dava via publicidade. As faixas de programação costumavam ter o nome da marca financiadora, como Philco TV Playhouse ou General Electric Theater, por exemplo. Havia liberdade para os produtores executivos dos estúdios pertencentes às marcas, sendo o sucesso o que determinava o que podia ser feito. Esse modelo de produção também veio do rádio.

$\mathrm{Na}$ década de 1930, as conhecidas soap operas radiofônicas eram financiadas por empresas do ramo de produtos de limpeza e consumo doméstico, por isso dedicadas às donas de casa, com suas histórias focadas em dramas domésticos, situações familiares e relacionamentos. As soap operas foram adaptadas para a TV no final da década de 1940, tendo é claro que se encaixar dentro das limitações produtivas do momento e, posteriormente, alargaram suas possibilidades técnicas com o surgimento do videotape, que, na década de 1950, permitiu a gravação e edição dos programas. (ESQUENAZI, 2010)

A primeira soap opera televisiva, Faraway Hill, foi lançada em 1946, pela rede DuMont. O gênero logo atraiu as emissoras concorrentes, o público e os anunciantes. (STARLING, 2006) Assim nasceu a ficção seriada televisiva que apresentava os mesmos personagens capítulo a capítulo e cujas peripécias era possível acompanhar em horário marcado.

Em 1951, a CBS lançou a primeira sitcom da TV, I Love Lucy (1951-1957), adaptação da série de rádio My Favorite Husband. A grande mudança na série, com sua ida para a TV, não se restringiu ao fato de que, a partir de então, seu público poderia ver os personagens e não só os ouvir. A personagem Lucy tornou-se protagonista e passou a nomear a série, além disso, a atriz Lucille Ball dispensou seu parceiro no rádio, que foi substituído por seu marido na vida real, Desi Arnaz. O casal não só interpretava, mas também produzia a série e deslocou sua produção de Nova York (sede da Emissora) para seu estúdio em Hollywood, Desilu (uma 
shipagem $^{14}$ anacrônica do casal Desi e Lucille). O material era gravado em película e depois enviado à Nova York para montagem. Além de editado e possuir uma qualidade fotográfica acima da média por conta da película, poderia ser novamente exibido, aumentando os lucros do produto. No entanto, assim como outros programas de TV, apesar de gravado, fazia uso de recursos utilizados nos audiovisuais ao vivo, como a filmagem em palco e o uso de plateia presente, reagindo aos acontecimentos da série. Inovou no uso de três câmeras simultâneas nas filmagens, reduzindo assim o tempo de produção para fazer diferentes takes. Esse modelo estabeleceu padrões técnicos que influenciaram o gênero nas décadas seguintes. Starling destaca que o uso de diferentes câmeras trouxe mais dinamismo e diferentes pontos de vista. (STARLING, 2006) (MACIEL, 2003) (ESQUENAZI, 2010)

A partir da década de 1960, mais da metade das transmissões já eram gravadas no videotape. Com isso, puderam ser desenvolvidos, cada vez mais, roteiros de ficção específicos para o meio, que contassem com condições técnicas mais sofisticadas e mais possibilidades narrativas. (STARLING, 2006)

A relação com o cinema e com os profissionais desse segmento impactaram também a produção televisiva e sua estética. Assim, a produção seriada para TV bebeu do rádio, do teatro e do cinema. Desses diálogos, e de inovações originárias no próprio meio, foram se estruturando os formatos que conhecemos hoje.

Outra série precursora foi Dragnet (1967-1979), lançada pela NBC, com forte influência cinematográfica, também adaptada do rádio e gravada em Hollywood. Utilizou equipes acostumadas a trabalhar com filmes de baixo orçamento. A série se inspirava nos diários de bordo da polícia de Los Angeles e inovou, tanto na narrativa, quanto no modelo de produção para TV. É considerada precursora das séries policiais. (ESQUENAZI, 2010).

A gravação em película melhorou a qualidade do produto, possibilitou sua edição e reexibição, aumentando a possibilidade de lucro. No entanto, aumentou seu custo de produção, tornando quase inviável que um único anunciante bancasse

\footnotetext{
${ }^{14}$ Shipagem vem do termo shipar, uma adaptação do termo em inglês ship (shipping) que vem de relationship e significa torcer. A ideia é juntar os dois nomes de um casal em um único nome. Pegase parte do nome de um e junta-se com parte do nome do outro. Assim, Desi mais Lucille fica Desilu, Evan mais Isak fica Evak, etc.
} 
sozinho toda uma faixa de programação. Os anunciantes então deixaram, de uma maneira geral, de se responsabilizar pela produção e passaram a financiar os programas junto a outros anunciantes.

Somou-se a isso um escândalo relacionado a jogos falseados patrocinados e produzidos por anunciantes, que fez com que a organização que controlava a televisão, Federal Communications Commission (FCC), decidisse que ter anunciantes no controle da produção do conteúdo da TV podia ser prejudicial para o meio e que, então, esse controle deveria passar para a mão das emissoras. Ao mesmo tempo, I Love Lucy e Dragnet provaram para os estúdios de Hollywood que produzir conteúdo serializado para TV poderia ser uma boa fonte de renda, cujo custo de produção na época era bem menor que o do cinema, a distribuição era simultânea e a duração da produção potencialmente sem limites. (STARLING, 2006)

Assim, redes de TV e estúdios se uniram. Essa dinâmica de produção recebeu o apelido "hollywoodização" da TV. Surgiu a função do produtor independente, alguém que apresenta projetos para uma rede. No caso de uma série, a rede checava se havia interesse dos anunciantes para o financiamento do piloto do produto. Se houvesse, ele era produzido e, mediante sua boa aceitação, poderia ser desdobrado em uma primeira temporada e assim por diante. (STARLING, 2006)

Na década de 1970, foram criadas diversas leis que tornaram mais rentáveis a produção para estúdios independentes, tanto em termos de ganhos comerciais, quanto de direitos de venda de suas produções, fomentando o mercado de séries. (STARLING, 2006)

Em pouco tempo, a TV se tornou um local de interesse público e de cultura nacional partilhada, devido à sua forte presença nos lares. As séries permitiram explorar narrativas que se desenvolvessem ao longo de um período de tempo, meses ou até anos, garantindo um público cativo.

Nesse período, as séries serializadas contínuas ficaram mais restritas as soap operas. As séries do primetime ${ }^{15}$ mantinham um modelo mais episódico. O modo

\footnotetext{
${ }^{15}$ Primetime é o período de exibição da televisão aberta considerado mais nobre. Nos Estado Unidos, assim como na maioria dos países, é um período noturno que costuma ir de 19 ou 20 horas até 22 ou 23 horas, ou seja, um período visto como pós trabalho, em que mais pessoas estão em casa para assistir TV.
} 
mais serializado trazia problemas comerciais para a indústria, uma vez que as reprises distribuídas pelos sindicatos tinham como premissa poderem ser rodadas em qualquer ordem e os departamentos de pesquisa dos próprios canais acreditavam que, mesmo as séries mais assistidas, só conseguiriam garantir a audiência de um terço das pessoas, de semana a semana. Optar por um modelo mais serializado apresentava-se então como um risco: seria um obstáculo à lucratividade com reprises e se considerava que a maioria das pessoas não ia acompanhar toda a série de maneira contínua. Além disso, as séries episódicas estavam fazendo sucesso, por isso as emissoras não viam muito sentido em sair de sua zona de conforto e correr riscos. (MITTEL, 2015)

A estrutura da TV comercial exigia um tempo exato por episódio e espaços para os breaks comerciais. As emissoras não garantiam nem a ordem de exibição dos episódios, nem quando estariam no ar. A produção acontecia durante o período em que a série ainda estava no ar e era ajustada segundo as intempéries e o feedback do canal, patrocinadores ou audiência. Segundo Jason Mittel, a TV costumava operar nas séries como em um modo infinito de storytelling, enquanto a série fizesse sucesso era mantida no ar. Por conta disso, a maior parte das séries do período carece de fim. Como vimos anteriormente, o fim representa também uma finalidade, uma rota para onde são levadas as ações de causa e consequência. Mittel considera que, por não poder ser vislumbrado um fim, não é de se estranhar que a maior parte das séries não fosse serializada. (MITTEL, 2015)

As narrativas das séries são compostas por universo, personagens, eventos e temporalidade. Mesmo narrativas episódicas possuem características seriais já que, em geral, seus episódios são situados no mesmo universo e apresentam os mesmos personagem a cada semana, ainda que o "caso da semana" não seja acumulativo, gerando uma continuidade. (MITTEL, 2015)

As soap operas já trabalhavam com a continuidade nesse momento e, segundo Starling, a evolução temporal foi introduzida em I Love Lucy, quando, em 1953, Lucille Ball ficou grávida. O nascimento na vida real de Desi Arnaz Jr. foi traduzido para o nascimento de Ricky Jr. na série. Para o autor, a importância desse evento não está na relação quase mesclada entre vida real e vida fictícia, mas no marco que cria para que os personagens se desenvolvam ao logo do tempo, inscrevendo-os na mesma dinâmica temporal do espectador. Personagens, atores e 
espectadores sofrem a passagem do tempo, fenômeno mais visível quanto mais longa a narrativa. Outro exemplo que o autor dá para esse fenômeno é a série Anos Incríveis (1988-1993), produzida pela $\mathrm{ABC}$, que acompanha o ponto de vista do personagem Kevin, desde seus 11 anos até a ida para a faculdade. (STARLING, 2006) O público cria fortes laços com o personagem ao acompanhar cada uma de suas descobertas. Identifica-se e projeta-se na relação que o protagonista estabelece com seu entorno e demais personagens.

Starling considera que o fator tempo por si só não trouxe grandes sofisticações para a narrativa até Dallas (1978-1991), produzido pela CBS. É com essa série que o autor considera que o advento do tempo complexificou a trama narrativa. Dallas fazia uso de arcos alongados e fortes ganchos narrativos. Mesclava temas como crime, política externa, lutas de família, traições conjugais, entre outros. A princípio, os executivos da CBS temiam que o público não se lembrasse dos acontecimentos e da evolução da narrativa de um episódio de uma semana para a outra, por isso, na primeira temporada os episódios eram mais independentes. $\mathrm{Na}$ segunda temporada, os roteiristas começaram a ousar mais, fazendo uso de recursos folhetinescos. Isso exigiu que o público acompanhasse a série semanalmente para não perder as reviravoltas. (STARLING, 2006) A terceira temporada terminou com disparos sobre um dos vilões e o público teve que esperar todo o verão, até o início da próxima temporada, para saber o desfecho. (ESQUENAZI, 2010) Este primeiro episódio levou $80 \%$ do público americano a ligar a TV na CBS para saber a resposta ao enigma. (STARLING, 2006)

A partir daí, o recurso da memória passou a ser levado em consideração na construção das séries. A longa duração das séries, que se mantinham no ar por temporadas, possibilitou ampliar o número de personagens, aprofundar suas personalidades e relações. (STARLING, 2006)

Dallas também é lembrada como a série que juntou homens e mulheres no primetime. As soap operas passavam de dia e eram destinadas ao público feminino, abordando questões de ordem sentimental, enquanto o primetime tinha como alvo o público masculino e abrangia uma narrativa mais de aventura. No início, os críticos tiveram até dificuldade de definir a série, pois era uma mistura de gêneros: uma soap opera que abordava questões de ordem política e criminal, mas também dos sentimentos daqueles que as viviam, agradando a homens e mulheres. Essa 
junção teve uma demanda comercial, uma vez que os programas tradicionais de polícia estavam em baixa e aborreciam as mulheres. (ESQUENAZI, 2010)

Pela mesma questão junto aos críticos passou Hill Street Blues (1981), que é tida como marco para as ditas séries complexas. Ela mistura gêneros como o documental, o humorístico, a crítica social, a intriga policial e os dramas pessoais. Como já dissemos, a série da NBC é centrada em uma delegacia de polícia. Na época, esta emissora estava na retaguarda entre as três grandes emissoras e precisava inovar de alguma forma. Resolveu convidar a produtora independente MTM, empresa reconhecida no mercado por fazer produtos inovadores de alta qualidade, cujo sócio, Grant Tinker, já havia sido diretor da NBC, para realizar uma nova série policial. O projeto foi delegado a Steven Bochco e Michael Kozoll que não se interessaram em fazer mais uma série policial, apesar da insistência da NBC. Chegaram a esboçar uma série centrada em um hotel de uma pequena cidade, onde entravam e saiam pessoas que enfrentavam dificuldades e situações variadas. $\mathrm{O}$ presidente da emissora, Tartikoff, acabou por ser condescendente com os roteiristas e disse que não seria uma série policial clássica, mas o retrato de uma comunidade que enfrenta problemas pessoais e profissionais, inserida no contexto social da esquadra de polícia. Essa perspectiva de humanizar os policiais e tirá-los do tradicional posto de heróis atraiu a dupla, que criou policiais com mais vícios que virtudes. Essa foi uma das razões que chegou a complicar sua aceitação pela emissora, mas a passagem do próprio Grant Tinker para a direção da NBC resolveu o problema. A série inovou no grande número de personagens e na trama, que se construía de relações entre eles, o que resultou em uma inovação estrutural: cada episódio possuía uma trama principal completa e subtramas secundárias, que se desenvolviam ao longo da temporada ou de toda a série. Os produtores identificavam as tramas mais populares, para aumentar o seu enfoque. A estética da série também revolucionou: a fotografia adotou uma forma de filmar e um grão mais próximo ao dos documentários e havia uma preocupação de usar enquadramentos que gerassem um desconforto frente àquela esquadra de desajustados, acentuando a ideia que queriam passar. (STARLING, 2006) (ESQUENAZI, 2010)

A série fez com que a NBC se tornasse a rede número 1, mas não de imediato. No início, a série não teve grande aceitação do público, mas despertou o 
interesse da crítica. Após ganhar 8 Emmys e por toda a sua repercussão midiática, acabou despertando a curiosidade do público, que foi engrossando seus números de audiência.

As pesquisadoras Mayka Castellano e Melina Meimaridis consideram Hill Street Blues como o ponto de início da segunda era do ouro, que demarcam como indo de 1981 até o início da década de 1990. Destacam como características dessa era a aproximação da estética da TV à do cinema e a produção de séries com elementos que depois estariam ligados à noção de qualidade. A terceira era de ouro da TV coroaria a consolidação da produção de séries de qualidade, iniciando-se com The Sopranos (1999-2007), da HBO. (CASTELLANO; MEIMARIDIS, 2018) Não farei uso dessas denominações, me mantendo na divisão proposta por Mittel (2010), que leva em conta a estrutura midiática e não o fator qualidade, em sua divisão. Essas são apenas duas entre as muitas divisões propostas por pesquisadores para estudar a história da TV.

A discussão sobre a qualidade na TV surgiu nos Estados Unidos, na década de 1980, e se popularizou com o livro MTM: quality television (1984), de Jane Feuer, Paul Kerr e Tise Vahimagi, que apresentavam a produtora independente MTM, que produziu Hill Street Blues, como responsável pela introdução do "fator qualidade" nas produções televisivas. A empresa dava mais liberdade às suas equipes criativas e apostava em um público jovem urbano, produzindo programas considerados "liberais" e "sofisticados". (CASTELLANO; MEIMARIDIS, 2018) O pesquisador Smith, em 1983, considerava que as produções da MTM eram caras e exigiam paciência e tempo para construir uma audiência. (SMITH apud CASTELLANO; MEIMARIDIS, 2018)

Cabe destacar que a primeira produção da MTM, que logo marcou seu primeiro sucesso, foi o Mary Tyler Moore Show que, ao contrário das séries femininas da época, era protagonizada por uma mulher independente e solteira, deslocando um drama feminino da seara do lar para o mundo do trabalho, com todos os seus desafios e questões. Mary era sócia de seu marido Grant Tinker na MTM. (STARLING, 2006) 
Castellano e Meimaridis citam Hill Street Blues também como berço do nascimento da figura do showrunner. ${ }^{16}$

Steven Bochco, criador de Hill Street Blues, pode ser apontado como um dos primeiros profissionais associados ao fenômeno da autoria na ficção seriada televisiva nos termos que entendemos atualmente. Contratado pela MTM para produzir uma série policial para a NBC, que vivia uma intensa crise de audiência, Bochco, à época um experiente roteirista, exigiu total autonomia no desenvolvimento do projeto, o que lhe foi concedido, a despeito da desconfiança inicial gerada pela repercussão negativa do piloto junto ao público. As batalhas travadas entre ele e a emissora e sua postura irredutível ante as tentativas de interferência dos executivos nos rumos da série são apontadas por Martin (2014) como um importante legado deixado pelo criador às gerações seguintes de showrunners. (CASTELLANO; MEIMARIDIS, 2018)

Além do papel do showrunner, pode-se dizer que essa forma de construção de narrativa também levou ao desenvolvimento de equipes de roteiristas e formas de trabalhar em conjunto que garantissem a produtividade, mas também à impressão digital da série, com papéis de supervisão de roteiro, reuniões e criações de dinâmicas que hoje são correntes no mercado.

Voltaremos a abordar a relação entre as séries e o quesito qualidade, no tópico a seguir, que fala da estratégia adotada por alguns canais para se diferenciarem da concorrência. No entanto, a qualidade proveniente de sua estética próxima ao cinema não é o quesito que mais nos interessa nesse estudo, no que diz respeito a Hill Street Blues, mas sim a sua complexidade.

O próprio Steven Bochco em entrevista para o documentário Hollywood Règne des Séries diz que Hill Street Blues foi a primeira série na qual ele trabalhou que possuía memória. E sobre isso explica: “quer dizer, cada personagem tinha uma vida, existia em extensão e evoluía através dos episódios, vivia uma vida própria e tinha aspirações além de ser policial”. (BOCHCO apud STARLING, 2006, p. 38)

Sobre isso concluiu Starling que a imagem que se tem dos personagens é cada vez mais próxima da psicologia comum e distante aos tipos mais esquemáticos. Eles passam a ser ambíguos e multifacetados, tão abertos às adaptações e expostos à vida quanto o espectador. (STARLING, 2006)

\footnotetext{
${ }^{16} \mathrm{O}$ showrunner costuma ser o produtor executivo da série e, frequentemente, é também o roteirista. Ele tem o controle criativo da obra. (CASTELLANO; MEIMARIDIS, 2018)
} 
A visão do personagem muito próxima às pessoas reais é descrita em uma das cartas enviadas para a socióloga Ien Ang, em resposta a seu anúncio publicado em uma revista feminina holandesa, pedindo que lhe dissessem o que achavam da série Dallas. Foi dito sobre uma de suas personagens: “esta mulher podia viver entre nós, com os seus problemas e seus tormentos. Ela é humana. Eu poderia ser como ela, por assim dizer". ${ }^{17}$ Essa pesquisa fez parte de um estudo de recepção publicado em 1982 e, a partir dele, a socióloga percebeu que a maioria das mulheres não se interessava pelas questões político econômicas abordadas pela série de sucesso, mas pelos sentimentos e emoções que as personagens femininas exprimiam, o que Ang chamou de realismo emocional. As personagens tinham dramas com os quais algumas mulheres se identificavam como podendo ser seus próprios. (ESQUENAZI, 2010)

Sobre esse efeito realista, Starling acredita que ele é expandido quando se tem um grupo de protagonistas ao invés de um único herói de peso. Os programas multi-plot ou ensemble shows trabalham com uma narrativa em estrutura modular. Há uma profusão de personagens e histórias que não começam nem terminam em um mesmo episódio. Algumas podem ser retomadas num episódio seguinte outras em outra temporada. No início de Hill Street Blues foram criadas tramas que se espalhavam de uma maneira mais fluida, mas já na segunda temporada chegou-se à fórmula hoje comum entre as séries procedurais em que há uma "trama A", referente a um caso que se desenvolve durante o episódio, e uma ou mais tramas, que se desenrolam mais livremente pelos episódios e temporadas, podendo ser retomadas quando interessar à narrativa. Esses enigmas deixados nos episódios vão mobilizando a curiosidade do espectador por seu desfecho, que não se sabe quando irá ocorrer. É essa teia tecida com múltiplos fios que passa a ideia de complexidade. (STARLING, 2006)

Quando se tem essas tramas múltiplas pode se trabalhar o efeito de realidade, levando o tempo que for considerado necessário para um evento se desenvolver na narrativa. O produtor da série médica $E R$, John Wells, revela que criaram uma evolução emocional para o personagem Dr. Benton, a respeito da morte de sua mãe, que foi dividida em onze episódios, tendo em conta que esse tipo de evento leva um tempo para ser assimilado e que há momentos em que as coisas

\footnotetext{
${ }^{17}$ ANG, Ien. Watching Dallas. Londres: Rouledge, 1991. Carta 2, página 44.
} 
parecem melhores e outros em que há recaídas. Da mesma forma, o fim de um casamento também não se resolve em um episódio. É uma simulação da vida dos personagens como uma vida real e Wells acredita que isso intensifica o senso de realismo da série. (STARLING, 2006)

A demanda de atenção e espectatorialidade constante, que as séries mais complexas exigiam, era também um componente que ampliava os laços afetivos entre o público e o produto midiático. Fortes laços afetivos se tornariam fundamentais na "era" que estava por vir, a Era Multi-canal, em que o aumento da oferta de canais fez com que as emissoras disputassem como nunca um público cativo.

\section{Era Multi-canal}

A segunda era, nomeada por Mittel (2010) como Era Multi-canal, se iniciou na década de 1980 e se concretizou nos anos 1990. Foi marcada pela segmentação possibilitada pela ampliação do número de canais disponíveis, com o desenvolvimento das tecnologias de TV a cabo e satélite. O objetivo principal dessas tecnologias foi superar os problemas geográficos e topográficos que impediam a chegada do sinal de TV em determinadas regiões, porém o aumento do número de canais foi igualmente impactante. Consequentemente, também ampliou a oferta de programas e a competição entre canais, tornando interessante para as emissoras desenvolverem produtos de nicho, voltados para diferentes públicos.

Os novos canais coexistiram com as três grandes redes (ABC, CBS e NBC) e podiam não depender tanto, ou até dispensar, o financiamento via publicidade, pois o público, ao contratar seus serviços, pagava um valor por assinatura.

Somaram-se a essa conjuntura duas novas tecnologias que impactaram a dinâmica do consumo de TV: o vídeo cassete e o controle remoto. O primeiro permitia que o público pudesse gravar programas para ver quando quisesse, podendo até revê-los, e o segundo, que cada pessoa montasse sua grade de programação, com a facilidade de zapear de canal, sem ter que se levantar para espreitar a programação de outra emissora a cada intervalo comercial. Esses dois aparelhos permitiram um maior controle por parte do público. 
$\mathrm{O}$ aumento do número de aparelhos de TV nas casas também permitiu que cada um assistisse o que quisesse. Com tantos canais, era preciso formular estratégias para atrair anunciantes. A audiência de cada programa também encolheu com o aumento do número de canais. As emissoras, então, perceberam que ter uma audiência pequena, porém dedicada, podia tornar um programa economicamente viável. (MITTEL, 2015)

Esquenazi cita como uma das estratégias encontradas pelas emissoras o desenvolvimento de séries tidas como "de qualidade", tendo como objetivo atingir um público com maior poder aquisitivo. (ESQUENAZI, 2010)

Essa estratégia foi adotada pela HBO. Inicialmente, o canal exibia filmes para um público interessado na qualidade de sua imagem, que era bem superior à do sinal aberto e das séries que eram veicularas naquele momento. Por conta do financiamento via assinatura, a emissora tinha mais liberdade que outras, que precisam de audiência e publicidade para se manter. Assim, começou a desenvolver produtos próprios, voltados para seu nicho de mercado, ousando na estética e na narrativa para produzir produtos diferenciados. Chegou a criar o slogan: isso não é TV, é HBO. (STARLING, 2006) O slogan tentava imprimir para a emissora a característica de ser tão revolucionária a ponto de não poder ser considerada TV. A emissora buscou recuperar para o meio o prestígio oriundo do cinema e uma de suas estratégias para tal foi contratar, para suas produções, profissionais da sétima arte. Só essa prática já foi suficiente para que muitos críticos e o público vissem o canal como possuidor de um selo de qualidade. (CASTELLANO; MEIMARIDIS, 2018) A HBO pode não ter feito só series populares, como Sopranos (1999), mas criou séries complexas, que mantiveram sua marca associada a séries mais sofisticadas, atingindo até um público que não costumava ver TV. (MITTEL, 2015) A apropriação de elementos cinematográficos ou literários também foi adotada por outros canais na busca por diferenciação.

De uma forma geral, a redes buscaram tratar de temas que ainda não tinham sido tratados na TV para se diferenciar. Naquele momento, a TV estava atrás do cinema no quesito de exibição de temas mais ousados. Afinal de contas, é preciso ter em consideração que a TV levava diretamente aos lares, para o centro de uma sala familiar, os conteúdos abordados no primetime. 
Segundo Starling, o fato dos baby boomers terem atingido a idade adulta fez com que eles fossem menos ao cinema, e este meio passou a ter como público-alvo majoritário os adolescentes, que inclusive eram um público que podia ser contemplado e cativado com os efeitos visuais desenvolvidos após o filme Guerra na Estrelas. Ficando mais em casa, as séries se tornaram uma boa opção de entretenimento e, para canais como a $\mathrm{HBO}$, interessava desenvolver projetos para esse público adulto, com bom poder de compra. (STARLING, 2006)

Acredito que outro fator pode também ter influenciado nesse momento a produção de séries com temas mais adultos no primetime: o aumento do número de TVs por residência, que fez com que cada um pudesse ver os programas que lhe interessassem em seu próprio quarto.

A proliferação dos canais ajudou a formar uma rotina de reprises, oferecendo mais oportunidades de acesso aos programas, já que havia uma grande disponibilidade de conteúdos. No entanto, a maior parte dos canais ainda exibia os episódios fora de ordem, desencorajando a narrativa teleológica. Contudo, a concorrência fez com que as emissoras precisassem se reinventar. Por muito tempo, a TV comercial norte americana evitou riscos, preferindo estratégias de imitação e fórmulas, mas isso já não era mais suficiente. Era preciso formular novas estratégias, seja de forma, seja de conteúdo.

O aumento da oferta levou a uma segmentação da audiência, que obrigou os canais a reverem seus modelos de produção, tendo em vista o que seu público queria consumir. Para atingir certos nichos de consumidores, começaram inclusive a incluir na grade temas que eram restringidos pelas emissoras, como sexo, drogas, violência e questões morais. Pedro Curi defende que o que impactou as narrativas televisivas, no entanto, não foi o conteúdo transgressor, mas a complexidade, considerando que é esta característica que faz com que o espectador seja fisgado, sinta-se surpreendido e fique viciado no produto. (CURI, 2015)

Mittel considera um dos maiores motivos para a emergência das narrativas complexas na TV a presença de criadores de cinema, atribuindo a eles o fato da mídia passar a ser vista de outra forma. A TV era interessante para os criadores e roteiristas, porque permitia que eles tivessem um maior controle de sua criação, além da possibilidade de experimentação e inovação. (MITTEL, 2015) 
A gravação em vídeo permitia que se revissem os episódios e seus momentos mais complicados, o que contribuiu para o desenvolvimento das séries complexas. Ainda que, em geral, depois se gravasse por cima de outras gravações, alguns programas podiam ser guardados e colecionados, aumentando o valor cultural desses produtos, tirando-os do fluxo efêmero. As emissoras também começaram a organizar boxes de DVDs das séries para venda. Essa experiência de controle, por parte dos expectadores, do tempo de tela começou com a fita cassete e o DVD, mantendo-se com o video on demand (VOD), sobre o qual falaremos mais no próximo tópico.

\section{Era da Convergência}

A terceira "era" foi apelidada por Mittel como Era da Convergência, fazendo referência também a Jenkins ${ }^{18}$. Está relacionada à mudança da TV com a presença das tecnologias digitais, sobretudo com a internet, os videogames e, posteriormente, ao vídeo on demand (VOD) e às redes sociais.

Se na era multi-canal a audiência com o controle remoto podia montar sua própria grade de $\mathrm{TV}$, zapeando pelas grades dos canais disponíveis, na era da convergência o controle do público sobre o que e quando assistir se amplificou. Com os serviços de VOD, as pessoas têm acesso a títulos como em uma biblioteca (ou várias bibliotecas).

Ainda que os canais a cabo já operassem com sistema de assinatura, seu modelo de receita complementava-se com publicidade, o que ocorre até hoje. Já nos portais de VOD há pouco espaço para a publicidade tradicional. Sua estratégia baseia-se no bundling, venda de produtos em pacotes, que era uma prática bem comum na era pré-digital, já que não fazia muito sentido vender um CD com uma única música ou uma revista com um único artigo. $\mathrm{Na}$ era digital, com produtos desvinculados a bens físicos, tornou-se financeiramente possível vender itens

\footnotetext{
${ }^{18} \mathrm{O}$ autor norte-americano Henry Jenkins difundiu o termo "convergência" em seu livro Cultura da Convergência, de 2007, lançado no Brasil em 2009. Para ele, convergência se refere "ao fluxo de conteúdo através de múltiplas plataformas de mídia, à cooperação entre múltiplos mercados midiáticos e ao comportamento migratório dos público nos meios de comunicação, que vão a quase qualquer parte em busca das experiências de entretenimento que desejam" (JENKINS, 2009) O termo reúne os conceitos de convergência dos meios de comunicação, cultura participativa e inteligência coletiva.
} 
individuais, no itunes ou na amazon, por exemplo. No entanto, o que os portais fazem é montar pacotes de conteúdos: montam biblioteca com produtos heterogêneos, que possuem custos de marketing menores do que teriam com vendas isoladas e, não tendo custo adicional, o público se sente mais seguro em experimentar novos programas. (LOTZ, 2018) Mas diferentemente do que acontecia com os bens físicos, o acesso é ilimitado e muitos podem desfrutar do mesmo conteúdo ao mesmo tempo.

Se a TV era vista por sua espectatorialidade, hoje precisa ser vista por seu engajamento, por isso os parâmetros de medição de índice de audiência mais tradicionais não conseguem acompanhar este tipo de modelo de consumo de bens culturais televisivos. O público que não segue programações lineares deixa de ser uma massa e passa a ser um indivíduo que realiza a sua jornada. Por outro lado, o fluxo digital de cada assinante é registrado pelo portal provedor do sistema de VOD, mas este guarda para seu uso interno esses dados. (MASSAROLO; MESQUITA, 2018)

As mídias que operam em modelo de portal fazem uma curadoria do conteúdo, com o propósito de oferecer bens que sejam valorados pelos assinantes. Essa dependência que se passa a ter de uma biblioteca cria novos padrões para a indústria. Antes os canais faziam seus títulos, exibiam, licenciavam para outros canais, mas a vida útil do produto não tinha um caráter perpétuo. Na biblioteca, os títulos desenvolvidos pelos canais passam a ter um maior valor de longo prazo. Muitos canais, com isso, estão fazendo os seus próprios portais e retirando os seus títulos dos portais maiores que os disponibilizavam. A pesquisadora Amanda Lotz alerta que, em um ambiente de abundância, a ferramenta de exclusividade pode encorajar o acesso ilegal, que permanece disponível, ao invés da assinatura. Do contrário, o preço acessível de alguns portais pode levar a espectadores que costumavam optar por acesso não autorizado a pagar pelo mesmo. (LOTZ, 2018)

Esse modo de distribuição também impacta a produção do conteúdo, seu storytelling e formato. Não tendo que contar com breaks comerciais e nem com uma minutagem exata para caber em uma grade, o desenvolvimento narrativo dos episódios pode seguir com mais liberdade suas demandas criativas. (LOTZ, 2018) Isso não significa dizer que algumas séries, mesmo sendo feitas para serem 
veiculadas via streaming, não possam ter em mente atingir mais janelas de exibição e, por isso, prever espaço para anunciantes no meio do programa.

O mais importante para uma série é fisgar a atenção de um público, que possui uma oferta muito maior do que a sua capacidade temporal de consumo, e desenvolver ganchos narrativos que façam com que ele mantenha seu desejo de saber mais sobre o desenrolar daquela história e o destino de seus personagens.

Essa também é a "era" da TV complexa, que Mittel considera que emergiu no final dos anos 1990 e continuou crescendo no século XXI. No entanto, não só a narrativa complexa não representava a maioria dos programas até 2015 (momento em que Mittel escreveu seu livro), como não era a mais popular (pelo menos pela Nielsen rating), mas, ainda assim, um número significativo de programas é constituído por narrativas complexas. A relevância de uma obra para o seu tempo não se dá por conter uma forma majoritariamente empregada, se fosse assim, cineastas da década de 1970 como Altman, Scorcese e Coppola, que faziam filmes diferentes de seu tempo, não seriam tidos como relevantes para o seu período histórico. (MITTEL, 2015)

Em Complex TV, Mittel cita que, no outono de 2001, foram lançadas três séries de espionagem The Agency, da CBS; Alias, da ABC; e 24 horas, da Fox. Todas tiveram um índice de audiência baixo na primeira temporada. A primeira série piorou na segunda temporada e foi cancelada, sem muito protesto de fãs, a segunda durou 5 temporadas e a terceira, mais de 10 anos. The Agency era a mais convencional, seguia o formato procedural típico de outras séries da CBS que foram bem-sucedidas, como CSI, NCIS, Without a trace e Cold Case. As outras duas eram mais inovadoras na narrativa, apesar da concepção popular que a TV deveria ser mais estereotipada para manter o interesse por muito tempo. Alias era a mais chamativa visualmente, com toque sonoro, enredo elaborado e uma complexa mitologia de história de fundo, que atraía uma pequena, porém dedicada, audiência. A série nunca alcançou a expectativa da $\mathrm{ABC}$, por seu alto custo, mas as críticas e o estrelato de Jennifer Garner mantiveram com esforço o programa por 5 temporadas, até que o sucesso que a rede teve com Desperate Housewives e Lost, levou ao seu cancelamento em 2006. 24 horas foi a mais surpreendente por seu formato de narrativa nada usual, em que cada episódio correspondia a uma hora da história em tempo real, com telas divididas, relógios e outros dispositivos atípicos 
para a TV. A série foi crescendo em audiência durante suas 8 primeiras temporadas e voltou ao ar em 2014. (MITTEL, 2015)

Mas como que a audiência de 24 horas foi crescendo ao longo do tempo? A série se beneficiou da venda de DVDs e de aluguéis. Assim, os que perderam a primeira temporada recuperaram o tempo perdido com esses aluguéis, que eram um fenômeno novo para o momento, e engrossaram o público da segunda, que teve um aumento de $25 \%$. (MITTEL, 2015)

Mittel considera que Alias e 24 horas mudaram o cenário americano das séries, pois sua complexidade e inovação no storytelling lhes permitiram sucesso, tanto de crítica e público, quanto econômico (no caso do 24 horas), ao mesmo tempo que séries convencionais, tidas como seguras para emissoras, se mostraram uma falência comercial.

Mittel considera que as séries complexas são uma forma narrativa que não demanda o fechamento narrativo das formas episódicas. Elas se desenvolvem no tempo por um acúmulo de eventos, não fazendo um reset ao estado de equilíbrio ao final de cada episódio. Mas destaca que uma série complexa não se restringe a essa característica. (MITTEL, 2015)

O autor cita Arquivo X (1993-2018) como um exemplo precursor de narrativa complexa, que oscila entre o arco do episódio e o arco da temporada, ainda que algumas vezes o monstro da semana tenha entrado em choque com a mitologia desenvolvida ao longo da série, criando incongruências. Considera que Buffy, The Vampire Slayer (1997-2003) e Angel (1999-2004) foram séries que conseguiram conciliar melhor os prazeres seriais e episódicos, pois nelas todo episódio fazia avançar o arco da temporada, ainda que oferecesse coerência e fechamento episódico. Os personagens ofereciam informações que seriam levadas adiante na temporada e as relações iam se desenvolvendo. Mas o autor chama atenção de que uma série complexa pode não ter uma serialidade contínua. Mittel cita Seinfield como exemplo. Em Seinfield (1989-1998), as normas de fechamento narrativo e resolução não são seguidas. Alguns episódios terminam com situações em aberto, como George ficando preso em um avião com um serial killer. A situação não serve como um gancho narrativo, já que será abandonada no próximo episódio, mas apenas como um final cômico. Algumas histórias até continuam, outras não, 
contudo nunca há um retorno a um momento de equilíbrio ao final do episódio. Mittel destaca que a maior parte das sitcoms atuais e das séries procedurais (médicas, de crime, etc) não negam o que ocorreu no episódio anterior, algumas apenas ignoram. (MITTEL, 2015) Diferentemente do que ocorre em South Park, em que Kenny morre e reaparece no episódio seguinte como se nada tivesse acontecido.

Sienfield, diferentemente das séries cômicas tradicionais, que começam com uma trama A e uma B complementar, começa com 4 tramas independentes, deixando que os espectadores pensem em como as histórias vão colidir, de uma forma que transforma uma narrativa serial em um elaborado jogo interno. $\mathrm{O}$ interesse despertado no público pela mecânica narrativa é outra característica que Mittel cita como fruto das narrativas complexas. Os fãs têm não só prazer com o mundo diegético da série, mas também com os mecanismos criativos de sua produção. (MITTEL, 2015)

Séries e filmes que entregam uma narrativa como peças de um quebracabeça convidam seu público a observar os seus mecanismos narrativos. O público tem prazer, tanto ao fazer descobertas, quanto ao ser enganado quando a trama tem uma reviravolta. Ele se surpreende e se satisfaz com a lógica interna da história.

Mittel chama de forensic fandom o grupo de fãs que busca padrões no produto midiático, controla se houve violação de convenções e sublinha inconsistências e problemas de continuidade. (MITTEL, 2015)

As séries complexas são desenvolvidas sem temer a confusão temporária do público. A falta de pistas específicas cria momentos de desorientação, fazendo com que o público se engaje mais ativamente para compreender a história e recompense aqueles que veem todos os episódios. A compreensão se dá ao longo do desenrolar narrativo. A satisfação está no balanço entre expectativa, surpresa e coerência.

A serialidade narrativa é definida pela entrega de conteúdos da história em fatias, ao longo de um tempo. Mittel sublinha que os enigmas narrativos apresentados nessas fatias levam o público a diferentes modos de engajamento, podem produzir suspense, surpresa, despertar a curiosidade ou estimular a teorização. A temporalidade é então um elemento fundamental para criar esses estímulos. (MITTEL, 2015) 
Mas voltemos às questões conjunturais da "era". As tecnologias digitais e as plataformas de conteúdo que surgiram a partir dos anos 2000 modificaram o entendimento do que é TV. Após um período em que muito se falou sobre uma possível morte da TV, percebeu-se que o que estava morrendo era o modelo de se fazer e consumir TV e não o uso do aparelho. Com a chegada da smart TV, que conectou a TV à internet, ela se tornou o portal para o consumo de diferentes plataformas audiovisuais e até auditivas, tais como as redes de streaming ou aplicativos como o spotify.

Em palestra que assisti na conferência Digitalks, a representante do twitter no Brasil (da época) falou sobre a relação de simbiose entre a TV e a rede digital. O conteúdo da TV é um dos grandes tópicos que alimenta o conteúdo produzido pelos usuários do twitter. Por outro lado, o conteúdo presente em seus trending topics motiva que seus usuários procurem assistir na TV o que está criando buzz na rede. Assim, uma plataforma é fortalecida pela existência da outra e elas se retroalimentam.

A TV pode ser vista, então, como uma entre as várias plataformas que fazem parte de uma ecologia de mídias. Quando a produção de conteúdo é pensada de maneira integrada para toda essa cadeia de mídias, em diálogo e complementariedade, temos a experiência de produção de séries transmídia.

O pesquisador norte-americano Henry Jenkins cita a evolução da TV americana, de séries com episódios estruturados de forma mais ou menos independente para estruturas mais serializadas (contínuas), como fundamental para a preparação da audiência para as narrativas transmidiáticas, que requerem um público mais ativo e com uma curiosidade aguçada que o leve a querer circular em busca de mais conteúdo. (JENKINS, 2011b)

Como vimos na introdução, esse pesquisador norte-americano trouxe o conceito transmídia para o âmbito da narrativa. A partir da exploração do conteúdo presente nas diferentes mídias, a audiência vai conhecendo mais sobre determinada história. Em resumo, para uma narrativa ser considerada transmídia, ela precisa unir multimodalidade, ou seja, a presença em múltiplas mídias; com intertextualidade radical, o que significa que o conteúdo presente em uma mídia deve se relacionar fortemente com o conteúdo presente em outra; com o propósito de compreensão 
aditiva, em outras palavras, a cada novo conteúdo acessado, a audiência deve receber novas informações sobre aquele determinado universo narrativo. Seu foco de estudo é pensar como o conteúdo está sendo passado através das mídias e na forma com que os fãs reagem a isso, interessado menos na contagem de plataformas, e mais na relação que as extensões de mídia estabelecem entre si. (JENKINS, 2011b)

Andrea Phillips acredita que existem duas formas de estruturar uma narrativa transmidiática: a primeira é partir de uma história única e fragmentá-la por várias mídias; a segunda é começar a contar uma história em uma mídia e continuá-la em outra, adicionando extensões ad infinitum. Acredita que ambos os processos podem resultar em narrativas coesas. Independente do caminho escolhido, o resultado final sempre será a fragmentação. (PHILLIPS, 2012)

A fragmentação é o processo pelo qual se constitui a serialidade e, como vimos anteriormente, em qualquer história seriada o gancho narrativo desempenha importante função, motivando o público a saber mais e, assim, a história se desdobra no decorrer de uma temporalidade. A diferença, no caso da narrativa transmidiática, é que é preciso desenvolver ganchos que também levem os fãs para outras mídias. Iremos aprofundar esse tema no capítulo 5.

Mittel diz que temos que analisar, além do texto, o contexto e os paratextos. Uma das razões centrais da Complex $T V$ ter se tornado uma grande tendência foi a disponibilidade de sites de fãs, que facilitaram as discussões coletivas e de decodificação. Esses sites não servem apenas para a audiência, mas também para os produtores, que podem acessá-los a fim de entender as práticas de consumo do programa e entrar em contato com o público.

A internet - em fóruns, blogs, redes sociais - possibilitou a formação de uma inteligência coletiva de troca de informação, interpretação e discussão. Nesse cenário, os enigmas presentes nas narrativas complexas motivam o engajamento do público nesses paratextos, que buscam sobretudo preencher os gaps deixados pela narrativa e debater teorias, além de conhecer todos os easter eggs ${ }^{19}$ que passaram despercebidos.

\footnotetext{
${ }^{19}$ Easter eggs são brincadeiras escondidas, em geral nas imagens de filmes, séries, jogos e sites. São dispensáveis para a compreensão da obra, mas ampliam a satisfação dos fãs que os encontram. $\mathrm{O}$ nome remete à brincadeira de páscoa de encontrar ovos escondidos.
} 
Como já dissemos, se o vídeo cassete e o controle remoto já haviam dado mais controle da programação para o público, esse fenômeno foi intensificado com o vídeo on demand via streaming. Uma das responsáveis pelas mudanças de hábitos de consumo e de produção de conteúdo foi a Netflix. Criada em 1997 como um serviço de locação de filmes que enviava o DVD para a casa das pessoas, a empresa modificou seu sistema de negócios em 2007, para disponibilizar também os filmes online. Três anos depois, em 2010, esse serviço já era maior que o serviço original. Os assinantes, que antes pagavam uma mensalidade para receber os filmes que queriam em casa, podiam acessar todo o conteúdo disponível na plataforma da Netflix via streaming. Nessa época, só era possível acessar a plataforma através do computador, mas, pouco tempo depois, a internet chegou à TV e aos dispositivos móveis, aumentando as possibilidades de acesso aos serviços de streaming. (CURI, 2015)

O principal conteúdo da Netflix em seus primórdios era Heroes, produção da NBC. Em 2011, eles começaram a investir em conteúdos originais, muitos deles transnacionais. A busca de parceiros locais nos países em que opera se tornou uma marca distintiva da empresa. Em 2013, lançaram House of Cards, que inovou por estrear já com todos os episódios da temporada disponíveis para serem assistidos, impactando nas formas de consumo das séries. A primeira série original brasileira foi 3\% (2016), de Pedro Aguilera. (CURI, 2015) (MASSAROLO; MESQUITA, 2018)

Na esfera da produção, Pedro Curi destaca que temos que ter em conta que o streaming foi uma atualização da TV e não algo inteiramente novo, considerando que, desde a década de 70, quando entraram as produtoras independentes, o padrão de produção de TV dos Estados Unidos não mudou muito, inclusive o modelo de produção de pilotos para a venda de séries funciona até hoje. (CURI, 2015)

Outra característica da plataforma que impactou o consumo foi o sistema de indexação e recomendação de conteúdo a partir de dados das atividades do usuário. A captura e análise desses dados ajudou a plataforma nas decisões de compra e compreensão dos hábitos de consumo de seus assinantes. (CURI, 2015)

O VOD também permite que os vídeos sejam vistos, revistos e pausados, assim como já faziam os vídeos cassetes e DVDs. Essa característica foi 
fundamental para que a discussão entre os fãs pudesse ser mais aprofundada. No entanto, a experiência de visão não simultânea de cada episódio, possibilitada principalmente pelo streaming que entrega toda a temporada de uma vez, faz com que as pessoas tenham medo de buscar informações e entrar em paratextos na web antes que acabem de ver tudo, pois, se o fizerem, podem se deparar com spoilers.

Antes do bingewatching, os gaps entre os episódios costumavam definir a experiência social em que as séries eram tema de conversas. Mittel fala ainda sobre a perda da discussão nos fóruns e do exercício de investigar e criar. Mas o bingewatching também pode ser visto como uma experiência mais imersiva. As séries com fortes ganchos narrativos motivam as pessoas a continuarem assistindo aos episódios para receberem suas recompensas narrativas.

É claro que o consumo desenfreado de qualquer espécie vai ser prejudicial em alguma medida e muitos estudos estão sendo feitos, relacionando bingewatching a suicídio e depressão. Até a Netflix está evitando o uso do termo, para se afastar de possíveis conotações negativas. Qualquer que sejam as conclusões desses estudos, sabemos que excessos fazem mal, mas que uma imersão consciente pode ser uma atividade prazerosa. Parece uma volta ao início desse capítulo, quando falamos que os folhetins estavam sendo acusados por sua capacidade alienante e altamente prejudicial, ao levarem um lazer imersivo aos dias de semana, que deveriam ser dedicados ao trabalho. A oferta dos conteúdos faz com que tenhamos escolhas de como assistir e qualquer escolha requer responsabilidade.

O pesquisador francês François Jost, em seu estudo sobre as séries norteamericanas, defende que seu sucesso se deve menos aos procedimentos visuais, narrativos e retóricos que utilizam e mais ao ganho simbólico que proporcionam ao espectador. (JOST, 2012)

O autor considera que essas séries têm uma forma de abordar o conceito de atualidade, que faz com que o espectador identifique as questões dos personagens como semelhantes às suas. As séries tratam de realidades transnacionais, mais abrangentes, como a nova ordem mundial pós 11 de setembro. Esse tipo de "atualidade" possui a característica de "persistência", dessa forma, o contexto não envelhece com tanta rapidez, ao contrário da "atualidade" de "dispersão", que faz 
alusão a acontecimentos pontuais que ocorreram recentemente no mundo, mas que em pouco tempo se tornam antigos ou são esquecidos. (JOST, 2012)

Outro fator identificado foi a impressão de realismo, com detalhes que não buscam imitar o real com perfeição, mas que conferem uma autenticidade à narrativa. Em uma série médica, por exemplo, autores e atores preocupam-se em captar os jargões, gestos, rotinas, nomes de doenças, para passar credibilidade para a representação de uma equipe médica. Isso não significa que a invenção não possa trazer elementos mais atrativos para uma realidade, como no caso de uma série policial onde, num episódio sobre os sem-teto de Nova York, foi inventado um grupo que vivia em bueiros. $\mathrm{O}$ autor defende que podemos ter como ganhos cognitivos, a partir de uma série, o saber enciclopédico do mundo; o saber fazer, as competências profissionais; e o saber ser. Ainda que sejam saberes parciais, satisfazem nosso libido cognoscendi, ao nos causar a impressão de que estamos descobrindo conteúdos desconhecidos. (JOST, 2012)

Tudo o que é visto em uma narrativa é sempre parcial. Até a nível biológico, nossos olhos não nos permitem olhar 360 graus. O ponto de vista está vinculado a um sujeito, no caso da narrativa, a um personagem. É entre público e personagem que se dá a conexão emocional com uma série. A possibilidade de valorização do personagem sobre a trama só se deu com a modernidade. Antes, os personagens estavam para a história como os agentes que cumprem as funções necessárias à trama. Personagens com personalidades complexas são fruto de um emaranhado de pensamentos.

Se antes as linhas entre as séries serializadas contínuas e as narrativas episódicas eram firmes, hoje são borradas e a complexidade narrativa não é mais tida pelas emissoras como arriscada. Diante de um público acostumado com as narrativas complexas, a narrativa subjetiva, que embaralha os pontos de vista, as costuras temporais e relacionais com múltiplos entrelaçamentos, são antes um estímulo a uma visão engajada do que uma perturbação à compreensão narrativa. 


\section{Narrativas que revelam múltiplos pontos de vista}

\subsection{Uma questão de perspectiva}

Uma viagem de férias para a casa de praia dos sogros é o incidente que transforma a vida do aspirante a escritor Noah Solloway. Ele e sua família de quatro filhos param para almoçar na lanchonete Lobster Roll, que fica na entrada de seu destino, a cidade de Montauk. Assim começa a série The Affair, pois nessa lanchonete trabalha como garçonete Alison, com quem ele terá um caso. Ou seria melhor dizer, teve, pois a série se reporta a fatos ocorridos cerca de dois, três anos antes do momento em que se narra. O primeiro episódio, assim como os episódios subsequentes, é dividido em duas partes. A primeira parte relata a história sob o ponto de vista de Noah, e a segunda, sob o ponto de vista de Alison, ambos estão sendo interrogados por um investigador a respeito de um crime, que não se sabe qual.

O que é projetado na tela é então a construção narrativa da lembrança desses personagens. Seus testemunhos ora convergem, ora divergem, são seletivos e possuem todas as distorções próprias tanto do processo de rememoração quanto do movimento que fazemos para conferir coerência narrativa ao caos dos acontecimentos. Soma-se a isso o lugar em que está situado cada personagem, seu contexto, o acesso a informação e preconceitos, que imprimem subjetividade a pretensa objetividade do relato dos fatos ocorridos.

Não iremos analisar a série nesse momento, o que será feito no capítulo 3, no entanto, gostaria de destacar essa cena em que eles se conhecem para que possamos entrar no debate da questão do ponto de vista.

Na lanchonete, a filha caçula de Noah se engasga com uma bola. Naquele momento conturbado e rápido, a visão do pai da criança é a de que é ele quem resolve a situação e consegue que a bola desentale. Na visão da garçonete Alison, por já ter sido enfermeira e saber o que fazer, orienta Noah a virar a criança de cabeça para baixo. Percebe que ele não dará conta de resolver, então se aproxima e bate nas costas da menina conseguindo que a bola saia. Ou seja, ambos se recordavam da cena como tendo salvo a criança. Em um primeiro momento, ouvir as duas histórias faz parecer que um dos dois está mentindo, mas entendendo a narrativa como passível de ter sido reconfigurada pela construção da memória, 
podemos entender que essa é a legítima forma com que cada um se lembra do fato. As diferenças presentes nos relatos não remetem a um senso de verdade, mas antes a um senso de visão. Ainda que em alguns momentos possamos supor pela palavra de outros quem está mais perto do que aconteceu.

Podemos destacar do descrito acima os conceitos de mentira, verdade e realidade. Para discorrer sobre eles, de maneira breve, vamos nos apoiar nos estudos presentes na História da Mentira, de Jacques Derrida e A construção social da realidade, de Peter L. Berger e Thomas Luckmann. Convém ressaltar que esse estudo não se propõe sociológico, apenas lançaremos mão das teorias desses autores para trabalhar com certos conceitos que serão importantes para o desenvolvimento da tese.

Derrida cita Santo Agostinho como um dos primeiros a teorizar sobre o que seria a mentira. Santo Agostinho considera que o primordial para algo ser caracterizado como mentira é a intenção. Se alguém conta algo falso acreditando ser verdadeiro, não é uma mentira, mas sim, um erro. Se alguém conta algo que crê ser mentira, mesmo que por uma casualidade do destino seja verdade, a pessoa não deixa de estar mentindo. Derrida conclui então que a mentira é um ato intencional, deliberado, relacionada ao desejo ou vontade de enganar. Ela permanece independente da verdade ou falsidade do conteúdo: daquilo que é dito. (SANTO AGOSTINHO apud DERRIDA, 1996)

Logo, se um personagem não tem a intenção de enganar, não podemos dizer que ele está contando uma mentira. Erro não é mentira. O autor também diz que o contrário da mentira não é nem a verdade e nem a realidade. De fato, não poderia ser, já que se baseia em um conteúdo que alguém apresenta de má fé crendo ser enganoso, mas essa pessoa pode estar enganada. Derrida diz, então, que o contrário da mentira seria a veracidade ou a veridicidade, que é o dizer ou o querer-dizer verdadeiro. Mais adiante, ele também diferencia verdade de realidade, argumentando que a verdade tem a ver com o valor de um enunciado estar em conformidade com aquilo que pensamos. (DERRIDA, 1996)

Tendo isto em consideração, o que importa para que algo seja considerado verdade é que acreditemos que o seja. Assim, a verdade não é a realidade, é uma 
interpretação da realidade, logo cada ponto de vista carrega a sua verdade, não sendo essa a realidade.

É possível, então que coexistam mais de uma verdade, se para diferentes pessoas, sob suas lentes, dizem a verdade do que consideram sobre um fato. Procurar pela verdade é então um problema insolúvel já que não existe uma verdade objetiva, mas interpretações que disputam para serem consideradas verdades.

Derrida aponta que a dimensão performativa faz a verdade. Quando uma pessoa considerada pela sociedade como uma autoridade em determinado assunto fala algo, aquilo se torna verdade para muitos, mesmo que não corresponda a realidade. Ainda que o dito seja depois desmentido, possivelmente essa informação não chegará a todos aqueles que receberam a informação anterior. (DERRIDA, 1996)

A informação errada pode não ter sido dada de má fé, pode ter sido fruto de uma ignorância ou preconceito. Apesar de não poder ser considerada uma mentira, é inegável seu poder de desinformação e de criação de uma falsa verdade.

Podemos concluir que tanto a mentira quanto a verdade dependem daquilo em que a pessoa acredita ser verdade e daquilo que ela diz diante dessa crença.

Para Berger e Luckmann, a realidade é um fenômeno que vai além da vontade do ser. No entanto ela é construída e relativa, o que significa que o que é "real" para uma pessoa, pode não ser "real" para outra. (BERGER; LUCHMANN, 2004)

A realidade é relativa porque o conhecimento que se tem da realidade é sempre conhecimento a partir de uma certa posição. O conhecimento humano é considerado na sociedade como anterior ao conhecimento individual, fornecendolhe a sua ordem de significação. Ainda que essa ordem seja relativa a uma situação sócio-histórica, ela é para o indivíduo a forma natural de olhar para o mundo. (SCHELER apud BERGER; LUCHMANN, 2004)

Para Weber e Durkheim, as sociedades possuem uma fatualidade objetiva, mas suas atividades exprimem um significado subjetivo. Defendem que a vida cotidiana se apresenta "como uma realidade interpretada pelos homens e, de modo subjetivo, dotada de sentido para eles, na medida em que forma um mundo coerente.” (BERGER; LUCHMANN, 2004, p. 31) 
Berger e Luckmann consideram que a realidade da vida cotidiana está organizada em torno do "aqui" do meu corpo e do "agora" do meu presente. Mas a realidade não se esgota nessa presença imediata. Através da linguagem, o ausente pode se tornar presente ao integrar outros tempos, lugares e pessoas. Nos campos semânticos da linguagem, a experiência pode ser objetivada e acumulada para ser transmitida para outras pessoas e gerações. (BERGER; LUCHMANN, 2004)

A construção social da realidade começa com a socialização primária. A criança ao se identificar emocionalmente com seus outros significativos e a refletir seus comportamentos torna dela aqueles papéis, conseguindo identificar a si mesma, adquirindo uma identidade. Não é um processo unilateral, mas uma dialética entre a identidade atribuída de modo objetivo e apropriada de modo subjetivo. A socialização primária é seguida por processos de socialização secundária, que com ela dialogam. É comum haver um embate quando há desacordo, pois o que já foi interiorizado tem a tendência de persistir. As socializações secundárias não requerem um outro significativo, dispensando identificação. (BERGER; LUCHMANN, 2004)

A realidade está sempre a ser reafirmada (ou negociada) na interação entre indivíduos. Tal como a realidade foi, no início interiorizada por um processo social, é também mantida na consciência por processos sociais. A nossa própria identidade está sempre a ser confirmada, principalmente por nossos outros significativos. Estar em sociedade é participar da dialética de exteriorização, objetivação e interiorização, que não se dá em sequência, mas de modo simultâneo. Para Berger e Luckmann, "o ponto inicial é a interiorização: apreensão ou interpretação imediata de um acontecimento objetivo como exprimindo sentido." (BERGER; LUCHMANN, 2004, p. 137) O fato de apreender a subjetividade de outra pessoa não significa que consegui interpretá-la de maneira adequada.

Uma determinada realidade está sempre a ser reafirmada contras as concorrentes. Podemos concluir que construímos a realidade de acordo com o nosso mundo interpretativo, que se formou na dialética entre nossas socializações primária e secundárias, formadora de nossa identidade e da lente sob a qual interpretamos esse mundo. Logo, a visão de realidade poderia ser tida como um sinônimo para ponto de vista, que também é demarcado pelo lugar do observador. 
O ponto de vista, segundo a definição do dicionário é o lugar onde fica o observador ou quem pretende ver, enxergar algo; ou, no sentido figurado, opinião própria, modo particular de entender, julgar ou perceber alguma coisa. É importante notar que no sentido concreto proposto pelo dicionário a relação com o lugar é demarcada, servindo então de metáfora para o sentido figurado.

Existe diferença entre apresentar pontos de vista sem fechar um sentido ou usá-los para, ao contrário, apoiar uma tese, como fazia, por exemplo, a simulação de diálogos nos textos de Platão. Ao escrever sobre Sócrates, Platão concebia conversas entre seu mestre e diversos personagens. Os personagens exprimiam suas mais diferentes opiniões, mas não com o objetivo de formar um mosaico de pontos de vista, mas ao contrário, para que seus discursos fossem rebatidos por Sócrates e esse os convencesse de suas ideias.

É importante lembrar também que os personagens não são pessoas, são discursos transformados em ação, logo a multiplicidade de pontos de vista expressos em uma obra de ficção é uma simulação, sem compromisso com referentes externos.

Ainda que sendo uma simulação, a questão do ponto de vista se relaciona a debates muitos importantes da pauta atual, como a do lugar de fala. Além de discutir sobre quem tem o direito de contar determinada história, a questão lança luz à relatividade da construção de verdades. Em sua síntese, esse movimento de debates deveria (pois, nem sempre o faz) chamar atenção para que sejam ouvidos todos os lados possíveis de uma história, a fim de se entender melhor o que cada um pensa sobre o ocorrido, em lugar de se buscar uma verdade única provavelmente inexistente.

Se temos em conta que nosso olhar é moldado, ele é uma visão parcial. A escritora Chimamanda ${ }^{20}$ denuncia em seu TED o perigo da visão parcial, da história única, pois ela forma estereótipos ${ }^{21}$. Esclarece que o problema dos estereótipos não

\footnotetext{
${ }^{20}$ Discurso de Chimamanda no TED. Disponível em: https://www.ted.com/talks/chimamanda_adichie_the_danger_of_a_single_story?language=pt-br ${ }^{21} \mathrm{O}$ estereótipo foi um termo que ganhou o sentido figurado que tem hoje na década de 1920, usado pelo publicitário norte-americano Walter Lippmann como algo que corresponde a uma imagem préconcebida que media nossa relação com a realidade. $O$ termo concreto vem das placas usadas na indústria gráfica que eram chamadas estereotipos, criadas por Firmin Didot, que substituíram os tipos móveis de Gutemberg, concentrando todos os elementos que precisavam ser impressos numa mesma página, agilizando assim o processo de impressão. O estereótipo é sempre uma representação de um dado real, que não necessariamente lhe faz jus, pois, em geral, o reduz a apenas um aspecto
} 
é serem falsos, mas justamente sua parcialidade, serem incompletos, pois assim eles reduzem, por exemplo, um povo a apenas uma de suas facetas. E como vimos anteriormente, segundo Derrida, quando se repete muitas vezes esse estereótipo, ele se torna uma verdade, uma história definitiva.

Aí reside o problema de se ter uma só visão e a importância de um pensamento plural, que relativiza essas verdades construídas.

Outro problema que afeta o ponto de vista é a limitação do que podemos captar da realidade, que esbarra com o que vai além da nossa compreensão. Para ilustrar cito Planolândia ${ }^{22}$, de Edwin A. Abbott, estudante shakespeariano que viveu na Inglaterra vitoriana e que criou um universo imaginário em que todos os habitantes de uma sociedade são planos, triângulos, linhas, quadrados, pentágonos, círculos... Nenhum tem altura, logo se os vemos no plano são todos linhas. Eles se reconhecem pelas mudanças formais que seus corpos criam ao se movimentar. Não vou me ater a explicar as regras dessa sociedade, que é totalmente hierarquizada, sem mobilidade social, cuja dinâmica chega a irritar de tão cruel, mas serve como crítica social. Para eles, não existem as noções de cima e baixo, pois só veem o plano.

Mas se chega voando um objeto tridimensional nessa sociedade e avista todos por cima? Ele só será visto quando pousar em terra e parecerá desaparecer do nada quando tornar a voar. O quadrado com quem se comunica enquanto voa acredita estar tendo uma alucinação, pois nada vê. Fica ainda mais preocupado ao perceber que ele some e aparece. Não querendo parecer uma aberração, o objeto tridimensional leva o quadrado em seu voo, que tem uma visão de sua sociedade totalmente inédita. Por estar fora de sua experiência, ele não consegue entender bem o que está vendo.

Ao voltar para sua dimensão, os amigos do quadrado veem ele surgir também do nada. Perguntam o que aconteceu, o quadrado não consegue explicar, pois ele não aprendeu na construção social de sua realidade nem palavras para expressar aquela experiência de maneira objetiva. Ainda que conseguisse, seria

de sua realidade. Carrega consigo preconceitos no sentido, também, de conceitos pré-concebidos, podendo estes serem úteis (no caso de ser um facilitador para uma avaliação) ou nocivos (por carregarem uma bagagem negativa) para nossa tarefa interpretativa. (BRITO; BONA, 2014)

${ }^{22}$ No original Flatland. ABBOTT, Edwin A. Flatland: a romance of many dimensions. Nova York: Dover Publications, Inc.,1992. (Publicação original: Londres: Seeley \& Co., 1884) 
extremamente difícil para seus amigos incorporarem em sua realidade algo que existe, mas que está fora de sua experiência. Por assim dizer que a apreensão do mundo é limitada.

Para evitar a vertigem de tanto relativismo, vamos voltar à narrativa, que, segundo Ricoeur, é o modo como imprimimos sentido ao caos dos acontecimentos. Logo, é através da narrativa que construímos a nossa realidade e que expressamos o nosso ponto de vista. (RICOEUR, 1994)

A narrativa é uma sequência de ações que se desenvolvem no tempo e que criam relações de causa e consequência. Isso é válido tanto como matriz de compreensão do mundo para pessoas reais, quanto para a construção de narrativas com personagens ficcionais. Ainda que a narrativa pós-moderna tente quebrar essa causalidade.

O simples fato de narrar já constitui uma interpretação. A ordem com que os fatos são relatados imprime sentido e expressa a subjetividade do narrador. A objetividade pode até ser um ideal a ser buscado, porém é preciso saber que é inalcançável.

O que se critica muito sobre o estruturalismo é a tentativa de separar a narrativa do discurso, que poderia ser dito também como a tentativa de tirar a sua subjetividade. Mas não existe narrativa sem pensar enunciação e ponto de vista.

\subsection{Narração e ponto de vista}

Ao longo dos séculos, as marcas do narrador foram ganhando destaque no debate sobre narrativa. $\mathrm{O}$ narrador em primeira pessoa é o narrador-participante, ele conta a história a partir do seu ponto de vista, por isso essa forma narrativa também é chamada de narração subjetiva. O narrador em terceira pessoa é um narrador que não é personagem da narrativa, ele pode ou não ser onisciente, ou seja, saber tudo sobre os personagens e a história. Ainda que não fazendo parte da história, esse narrador em terceira pessoa pode, em alguns momentos, fazer alguns comentários em primeira pessoa, como os narradores sarcásticos de Machado de Assis que conversam com o leitor. 
A pesquisadora Vera Figueiredo nos lembra que no romance realista típico, a reflexão era de ordem moral, uma tomada de partido contra determinados personagens. Já no romance moderno, a reflexão volta-se para a indagação do próprio sentido de narrar, critica-se a busca de objetividade como sendo ingênua, rejeitando-se as convenções realistas em nome da incoerência da própria realidade. Trata-se de uma tomada de posição contra a própria representação. (FIGUEIREDO, 2010)

Tendo em conta o ceticismo na representação objetiva da realidade, os escritores e artistas modernistas se preocupavam em deixar claro os mecanismos produtivos de suas obras, para impedir que o público desfrutasse delas sem nenhum distanciamento crítico. Relembravam a todo tempo de que se tratava, não de uma realidade, mas de uma ficção. Consideravam que a própria pretensão do narrador de representar a realidade já se imbuía de uma ideologia. Por isso, se afastavam do narrador em terceira pessoa, pois aparentava realizar uma representação objetiva.

O uso da primeira pessoa ganhou popularidade pela transparência que estabelece com o leitor de que o que se narra é o relato de um personagem, enquanto tal, passível de desconfiança. Alguns autores, na tentativa de fugir da falsa objetividade, também optaram pelo caminho de usar quase só diálogos, com mínima intervenção.

Essas preocupações são fruto da falência do projeto iluminista, que buscava um universalismo que se mostrou problemático, com as atrocidades produzidas em prol de utopias pretensamente universalistas, sendo o Nazismo o maior exemplo do terror gerado pelas totalizações.

O fato de o narrador imprimir ordem aos acontecimentos já confere a eles sentido. Mas a narrativa em primeira pessoa deixa claro que se trata do ponto de vista de alguém. É inclusive comum, nas narrativas modernistas, o narrador fazer uma autocrítica, lembrando que sua narração tem um viés ideológico. Tal postura segue ocorrendo até hoje, como será possível conferir no estudo de caso The Lizzie Bennet Diaries, que será analisado no capítulo 5.

O uso da primeira pessoa caminha junto com a valorização do olhar antropológico, que tenta recuperar o real a partir do olhar do outro, recorrendo frequentemente ao testemunho. 
Mas a não confiabilidade do narrador não é tida só como um problema, pode também ser considerada uma característica interessante para ser explorada pela ficção. Depois voltaremos para esse ponto, mas primeiro vamos nos ater às grandes críticas feitas à narrativa.

A não confiabilidade do narrador gerou uma desconfiança da ficção como um todo. $\mathrm{O}$ fato de ter um roteiro foi considerado por alguns como um fechamento totalizante, em tensão com a proposta de uma narrativa aberta. Os autores modernistas viam a montagem como um caminho para evitar esse fechamento e passar uma pretensa espontaneidade, por isso tentavam criar outros mecanismos para quebrar o fluxo narrativo, o qual consideravam alienante. Assim, a montagem chegou a ser usada pelas vanguardas artísticas do começo do século XX, tendo como objetivo criar efeitos perturbadores e chocantes. Entretanto, a cultura de massa, pouco a pouco, se apropriou desses procedimentos, e a estética do choque tornou-se cotidiana.

O pesquisador franco argelino Jacques Rancière recorre à metáfora do fio perdido ao dissertar sobre a ficção moderna. Para o autor, a narrativa representa um fio que costura o sentido e as ficções modernas perdem esse fio ao subverterem princípios próprios à ficção desde Aristóteles: o desenrolar das ações em uma lógica causal a partir das necessidades dos personagens e da verossimilhança. (RANCIÈRE, 2017). Vilem Flusser usa uma metáfora semelhante, um colar de contas, para representar a cultura escrita cartesiana, onde se inscreve a utopia de que poderia haver um fio que unisse todas as contas, cada conta representando um conceito, criando uma conexão de sentido entre elas. (FLUSSER, 1985) De Foucault a Didi Huberman, a descontinuidade foi celebrada como um valor. Huberman defende o uso da imagem como lampejos que iluminam e apagam. (DIDI-HUBERMAN, 2011)

Lev Manovich anuncia o fim da narrativa com a cultura do arquivo, devido a seu caráter descontínuo e o oferecimento de informações simultâneas. O autor considera que, em nosso momento histórico, estamos mergulhados em uma cultura de fragmentos, que a narrativa não está mais no centro. A tecnologia digital favorece a compulsão por arquivar, mas apenas arquivar não garante a compreensão de uma informação. Aqui está o problema: fragmentos para serem interpretados e significados têm de contar com a narrativa para dar-lhes sentido. O elogio à lógica 
de arquivo vem do fato de ser considerada como antídoto à temporalização projetiva da história que representaria o fantasma da totalização. (MANOVICH, 2006)

$\mathrm{Na}$ lógica da cultura de arquivo nada se perde, tudo está arquivado. A rigor nada é priorizado e tudo tem igual direito de ser guardado. Como fazer uma escolha, então? O que ver primeiro? Se por um lado, é positivo que se tenha uma oferta grande de conteúdo que poderia representar muitos pontos de vista, por outro sem que se dê qualquer dica de priorização pode ficar muito difícil escolher. Os servidores de streaming, como a Netflix, fazem recomendações baseadas em outras coisas que você viu, o que tem o risco de você se aprofundar em uma bolha e só ver conteúdos parecidos, ainda que você possa ter um gosto bem mais eclético, mas também ajuda a poupar tempo de escolha e que elas sejam, em geral, mais assertivas. Será que entre uma cultura de arquivo, de certo modo anárquica, e uma narrativa vista como totalizante não há um meio termo?

A desconfiança na ficção caminha junto com a desconfiança de que seria possível falar pelo outro. Aqui entra o que falamos sobre a visão etnográfica e a valorização do documentário como um gênero que seria capaz de melhor representar a realidade. Assim como os autores modernistas, cineastas como Eduardo Coutinho se preocupavam em mostrar o processo criativo para o espectador, valorizando o acaso que permeia o documentário.

Vera Figueiredo, discordando da associação direta entre narrativa ficcional e totalização, lembra a capacidade da ficção de criar mundos possíveis e produzir deslocamentos no sentido de nos levar a olhar através dos olhos dos outros. $\mathrm{O}$ ato de ficcionalizar é um convite para sair de si, exercitar a empatia. (FIGUEIREDO, 2017) Essa característica da ficção é algo que permite a criação de lugares alternativos ao real, podendo expandir a nossa construção social da realidade.

O texto aberto é polissêmico, por apresentar vários caminhos. Esses caminhos possíveis podem ser desenvolvidos a partir de múltiplos narradores, múltiplos pontos de vista. Um texto com uma pluralidade de vozes é um texto polifônico. Em outras palavras, a polifonia é a presença de várias vozes no interior de um mesmo texto. Podemos dizer que a série The Affair é uma série polifônica, pois retrata uma mesma história através de diferentes testemunhos. Os personagens têm uma percepção diferente dos fatos. 
A multiplicidade de vozes e a pluralidade de discursos é um recurso que, segundo Mikhail Bakhtin, caracteriza a obra de Dostóievski: seu romance seria polifônico. Bakhtin considera a polifonia como um marco na concepção moderna de romance. O que passa a interessar é o ponto de vista do personagem sobre o seu contexto e sobre si mesmo. (BAKHTIN, 2003)

Convém lembrar que narrativas com diferentes pontos de vista são anteriores à Dostóievski. As novelas epistolares, por exemplo, já reuniam cartas e documentos, apresentando múltiplas vozes dentro de um mesmo texto através dessas colagens.

O pesquisador François Jost identificou como um valor o amplo leque de possibilidades abertos pela narrativa não confiável, de trabalhar essas múltiplas perspectivas entrando em contato com a intimidade dos personagens. $\mathrm{O}$ autor destaca que explorar múltiplos pontos de vista fragmenta a figura do herói. Jost considera que o herói único e monolítico privilegia os seres excepcionais. O grupo de heróis, por outro lado, permite que sejam exploradas dimensões mais humanas dos personagens, privilegiando as relações internas entre o grupo (JOST, 2012), relações essas que podem tratar de questões e sentimentos que vivenciamos em nosso dia a dia.

A narrativa multiperspectiva valoriza os personagens, uma vez que está ancorada em sua construção social da realidade. O ponto de vista significa e contextualiza a história. Essa tendência de pensar a narrativa a partir dos personagens é também fruto de um centramento no homem. Lembremos que, para Aristóteles, e grande parte dos seus sucessores, o mais importante era a trama e não os personagens. Estes eram secundários e contribuíam para a narrativa como elementos que fazem a trama avançar.

Mas quando o relato de um personagem é incongruente ao relato de outro e não temos nada que possa desmentir um ou outro? Nesse caso, não podemos inferir ao certo o que se passou na trama. Diante dessa dissonância, chegamos ao efeito Rashomon. 


\subsection{Efeito Rashomon}

Não poderíamos terminar esse capítulo sem citar Rashomon, filme japonês de 1950, dirigido por Akira Kurosawa, que possui uma estrutura narrativa na qual não é possível obter a verdade sobre um acontecimento, devido ao conflito de informações presentes nos diferentes testemunhos que relatam uma mesma história.

O uso do termo "efeito Rashomon" tornou-se frequente em diferentes áreas. Além da antropologia, da psicologia e do direito, podemos citar também, como é claro, a comunicação, a cognição, a epistemologia e a sociologia. (ANDERSON, 2016). O chamado efeito Rashomon se dá quando testemunhos de um mesmo acontecimento oferecem relatos ou descrições substancialmente diferentes, mas igualmente plausíveis. Antropólogos, como Karl G. Heider, e psicólogos consideram a subjetividade da percepção e da memória como uma das possíveis chaves para que o efeito ocorra. (MAYOS, 2010) Já a professora de Direito Orit Kamir, diz que o padrão típico "Rashomon" são as diferentes versões factuais que aparecem quando se advoga de uma maneira que reflita antes o interesse próprio que a objetividade. (KAMIR, 2000) Daí podemos concluir que o efeito Rashomon pode ser causado por pessoas que contem uma história diferente, por conta de sua própria construção de realidade ou mesmo porque, deliberadamente, mintam em proveito próprio.

O pesquisador Gonçal Mayos cita o ciclo de romances do escritor britânico Lawrence Durrel, escrito entre 1957 e 1960, que é composto por quatro livros chamados de o quarteto de Alexandria. Cada um possui o nome de um dos personagens: Justina, Balthazar, Mountolive e Clea, que contam suas versões de um mesmo acontecimento. Tanto o ciclo de romances quanto o filme japonês possuem uma lógica similar, mas o filme atingiu tal prestígio no ocidente que foi ele o escolhido para representar o efeito. (MAYOS, 2010)

O roteiro de Rashomon é do próprio Kurosawa e de Shinobu Hashimoto. Foi desenvolvido a partir dos contos de Ryunosuke Akutagawa: "Rashomon" e "No Bosque". O filme é um marco da entrada do cinema japonês no ocidente. Despertou grande interesse da crítica norte americana e europeia, além de ter sido premiado em diversos festivais: leão de ouro, prêmio da crítica em Veneza e Oscar de melhor filme estrangeiro. Curiosamente, o filme não foi, a princípio, bem visto no Japão: 
era tido como monótono e confuso, além de ter muitos palavrões e uma cena de beijo chocante para os japoneses nos anos de 1950. O próprio estúdio não queria mandar "Rashomon", quando foram convidados para o festival de Veneza, só o fazendo por insistência do representante da Italian Films em Tokyo. O êxito internacional, no entanto, fez com que seus próprios compatriotas pudessem admirá-lo. O filme lançou o nome de Kurosawa e abriu as portas para outros filmes japoneses. (GRANDÍO PÉREZ, 2010) (MAYOS, 2010)

O que mais chamou a atenção dos críticos ocidentais foi a linguagem inovadora de representar visualmente os flashbacks dos relatos multiperspectivos, onde a verdade é corrompida pelo interesse de quem a conta. Kurosawa levantou muitas perguntas sobre a natureza humana, suas ambiguidades, sobre a dualidade de serem capazes de fazer o mal, mas também o bem. Ele não fecha as questões que levanta, as mantém abertas para reflexão. (GRANDÍO PÉREZ, 2010)

A história começa com o encontro de três homens, entre eles um lenhador e um sacerdote, que se abrigam da chuva debaixo das ruínas do templo de Rashomon. Eles estão perturbados e falam sobre um acontecimento incompreensível. O último homem a chegar ao templo nada sabe sobre o que se passou e fica curioso com o que pode ser assim tão perturbador, tornando-se um ouvinte da história. Eles vão lhe contando todos os relatos que ouviram no tribunal: o do bandido Tajomaru; o da mulher do samurai morto; o do samurai morto, através de um médium; e o do próprio lenhador, que ao afirmar veementemente que todos os relatos são falsos, resolve contar tudo o que viu, mas que não revelou quando foi interrogado no tribunal.

\section{Versão do lenhador no tribunal}

O lenhador diz que, quando foi para as montanhas pegar madeira, encontrou as roupas de uma mulher, em seguida, o cap de um samurai, depois uma corda, até tropeçar em um corpo. Assustado, correu o máximo possível para chamar a polícia e prestar seu testemunho. 


\section{Versão do bandindo Tajomaru}

Tajomaru diz que ficou encantado com a mulher do samurai e decidiu tê-la, mesmo que para isso tivesse que matar seu marido. Mas, ao perceber que ela também o queria, apenas amarrou o samurai com uma corda. No entanto, ela lhe teria dito depois que o marido tinha que morrer, pois sua vergonha não poderia ser conhecida por dois homens. Tajomaru diz que cortou a corda e ofereceu a espada ao samurai, para que duelassem por ela, e, então, o matou. Ao ser perguntado sobre a mulher, diz não saber seu paradeiro, pois ela havia sumido e achou que não valia o esforço de procurá-la. Sobre a espada desaparecida do samurai, diz ter trocado por licor.

\section{Versão da mulher do Samurai morto}

Ela diz que um homem de kimono azul, depois de forçá-la a se entregar para ele, orgulhosamente anunciou que era o infame Tajomaru e ficou rindo de seu marido, que estava amarrado. Depois roubou a espada do samurai e foi embora. Ela correu para abraçar o samurai e, então, percebeu seu olhar frio e indiferente. Pediu que a matasse, mas que não a olhasse assim. Ela teria pego a adaga, soltado as cordas do marido para que ele lhe tirasse a vida. Segundo ela, o olhar dele se mantinha tão indiferente que a deixou nervosa, a ponto de desmaiar com a adaga na mão, apontada para frente e que, quando recobrou a consciência, a adaga estava no peito do samurai. Disse que, em choque, nem se lembrava como havia deixado a floresta. Mas que lembrava de estar no riacho e tentar se matar, tendo fracassado.

Convém aqui destacar que, na versão que eu assisti, em nenhum momento vi alguma legenda que indicasse que a mulher tivesse testemunhado que matou o marido. Alguns autores dizem que ela que matou o marido, outros que ela deixou isso implícito. Robert Anderson, afirma, em seu artigo The Rashomon effect and Communication, que a mulher teria dito especificamente que matou o marido. (ANDERSON, 2016) Aqui chegamos a um efeito Rashomon dentro da própria análise de Rashomon. Por conta de não compreender japonês, não posso afirmar se ela diz ou não que o matou. Na versão legendada, a que tive acesso, isso não é em nenhum momento verbalizado, ou melhor dizendo, não aparece escrito. Cheguei a pensar que, como ela desmaiou, até poderia ter sido o próprio marido a cometer 
suicídio com a adaga dela. Me senti sozinha nessa interpretação, até ler o artigo da pesquisadora Orit Kamir, que também levanta essa hipótese. Me pergunto se essa percepção foi influenciada pelo fato de sermos mulheres e o próprio filme, como veremos mais adiante, naturalmente por sua estrutura colocar a mulher em uma posição de culpa. A forma como o filme é montado, fazendo-se uma analogia aos tribunais, deixa a mulher nesse lugar. (KAMIR, 2000)

\section{Versão do Samurai via médium}

O samurai diz que o bandido atacou sua esposa e depois tentou consolá-la, dizendo que, como agora estava desonrada, não poderia mais ficar com o marido e que só fez isso por amor a ela. Diz que ela pareceu entrar em transe e disse a Tajomaru para levá-la onde quisesse. Ele, então, roubou a espada do samurai e ia partir com ela, quando ela lhe pediu que matasse seu marido, pois não podia partir com ele, enquanto o samurai estivesse vivo. $\mathrm{O}$ bandido, pálido com esse pedido, jogou a mulher no chão e perguntou ao samurai o que queria que fizesse com ela. Ela então fugiu, o bandido chegou a correr atrás, mas sem sucesso em alcançá-la, voltou para soltar as cordas que mantinham o samurai preso. Por conta de sua atitude, o samurai deixou que partisse. Diz que ouviu alguém chorar, referindo-se a ele mesmo, avistou a adaga da mulher no chão e enfiou no próprio peito. Quando já estava perdendo a consciência, alguém gentilmente retirou-lhe a adaga.

\section{Nova versão do lenhador}

O lenhador acaba assumindo que testemunhou todo o ocorrido e conta sua versão.

Afirma que o samurai não foi morto por uma adaga, mas por uma espada. Ele revela que achou o chapéu da mulher, mais adiante avistou a mulher chorando e viu Tajomaru se vestindo atrás de um arbusto, enquanto implorava pelo perdão dela e a pedia em casamento. Que poderia deixar de ser bandido, para ficar com ela, mas que se ela negasse, teria que matá-la. Ela diz que é uma mulher e por isso não pode decidir nada. Então desamarra o marido e se joga ao chão, deixando a decisão para ele. Antes que Tajomaru se aproxime dele para duelar, o marido diz que não vale lutar por ela. Diz que ela esteve com dois homens e pergunta a ela porque não 
se mata. Diz a Tajomaru que não a quer, que pode ficar com ela. Tajomaru analisa a situação e resolve ir embora. Ela tenta segui-lo, mas ele ordena que não o faça. $\mathrm{O}$ samurai manda a mulher parar de chorar, mas o bandido pede que a deixe chorar, pois defende que as mulheres são fracas por natureza. Nesse momento, acontece uma reviravolta. A mulher começa a rir histérica, dizendo que eles eram os fracos, por não tomarem uma atitude de homens e lutar por ela. Que achou que Tajomaru poderia livrá-la de um homem fraco, mas que ele era como o marido. Ela ri compulsivamente deles, fazendo com que se sintam intimados a iniciar um duelo. Depois de uma longa luta, o bandido consegue matar o samurai já desarmado, rouba a espada do samurai e a mulher consegue fugir.

Ao ouvir o relato, o último homem a chegar zomba dizendo que o lenhador também está mentindo. Desacredita também da sua versão e o acusa de ter visto tudo e não ter feito nada e, ainda, de ter roubado a adaga. Como seria possível acreditar em algum dos testemunhos, quando todo o dito sempre está de acordo com o interesse de seu locutor? No fim, não chegamos a nenhuma conclusão se não a impossibilidade de entender o que de fato aconteceu.

O recurso de usar flashbacks na narrativa já havia sido usado, em 1941, em Cidadão Kane. A novidade trazida por Kurosawa foi que a representação dessa volta ao passado não significava que a história estampada na tela fosse verdadeira. (GRANDÍO PÉREZ, 2010)

Não é uma ficção direta, que mostra o que aconteceu, assim como ocorre em The Affair, onde a imagem representa o que dizem ter ocorrido e não uma realidade pretensamente objetiva. A narração dos personagens é guiada por seus próprios interesses, para se proteger ou justificar suas ações. A diferença para The Affair é que, enquanto em Rashomon claramente há muita mentira envolvida, na série não sabemos se eles camuflam a verdade ou se contam os fatos simplesmente como se lembram.

É importante notar que em Rashomon as imagens também seguem a forma de narrar das testemunhas no sentido estético (ANDERSON, 2016), ainda que mantendo fortes semelhanças que mantém uma unidade.

Gonçal observa que os críticos veem o filme como uma clássica exploração da decepção do homem com o próprio homem e da relatividade da verdade, ou 
como a demonstração de que a verdade para um é ficção para o outro. A soma dos relatos não é uma soma que permite encontrar a verdade. (MAYOS, 2010)

Juntos, os relatos dos personagens de Rashomon são controversos e não há nenhuma chave possível para saber quem mente. A ambiguidade persiste. O filme, mais que sobre um assassinato e um estupro, é sobre a manipulação de eventos por narrativas interessadas e testemunhos egoístas. (GRANDÍO PÉREZ, 2010)

Tanto a voluntariedade da verdade, quanto a confiança na humanidade são ameaçadas pelos relatos incompatíveis e a impossibilidade de se chegar a uma única versão, que poderia ser considerada a verdadeira.

Tendo em vista que a realidade de cada pessoa é específica, seria igualmente impossível, em qualquer situação, chegar a uma verdade absoluta, mas as perspectivas podem ser mais convergentes ou divergentes.

Kurosawa cria subterfúgios para fechar o filme sem tomar partido de qualquer um dos personagens. Ainda assim finaliza o filme tentando passar uma mensagem positiva de que é possível ainda ter fé na humanidade, apesar de toda a sua ambiguidade e egoísmo, ao mostrar que o lenhador, com todos os seus erros e pecados, resolve adotar uma criança que encontram abandonada.

No entanto, a forma como o filme é montado pode criar uma leitura que influencie a visão dos relatos. Orit Kamir analisa os depoimentos no tribunal, segundo a ordem padrão de um julgamento. O primeiro a falar apresenta as acusações. O primeiro depoimento é o de Tajomaru que, apesar de assumir ter assassinado o samurai, coloca a culpa na mulher por ter mandado matá-lo, o que já seria considerado um crime. O segundo momento corresponde à defesa. A segunda a depor é a mulher, sendo importante observar que o filme não mostra o estupro. Ela só comenta que foi tomada a força, em oposição à grande cena em que Tajomaru diz ter sido consensual o que aconteceu. (KAMIR, 2000)

Convém aqui fazer um parêntesis: de que a mulher carregava uma adaga para, caso houvesse qualquer chance de violação, se matar antes, para que a honra do marido não fosse atingida. A honra na sociedade japonesa do período estava acima da vida. As meninas eram ensinadas a como se matar com discrição com suas adagas. A mulher era tida como um objeto, o que é claramente percebido com a forma que tanto o bandido quanto o samurai a tratam. Quando um perde o interesse, 
o outro também perde. E quando um a vê bonita, o outro também a vê. Mas, por ter sido usada por outro, o samurai não a quer mais. Ela então, culturalmente, já seria culpada por ter deixado que a honra do samurai fosse manchada. (KAMIR, 2000)

O terceiro relato, o do samurai, também a condena por ter pedido que o matasse, assim como o do lenhador, e com isso ela acaba ficando com o lugar de culpada, ignorando-se o fato dela ter sido vítima. O bandido reforça esse papel de culpada, quando diz que não pode resistir a ela, como se ela tivesse causado toda a situação. No terceiro relato, o samurai que nada conseguiu fazer para evitar que a violassem, se mata com a adaga da mulher, simbolizando que ele morreu porque ela não soube resolver sozinha a situação de se matar e, por isso, teve que cometer o suicídio. Ainda que não se chegue a uma conclusão do que ocorreu de fato, essa leitura de Orit demonstra que a mulher é mostrada como culpada. Ainda que mantendo a culpa de ter pedido que matasse o samurai, no relato do lenhador poderia ser inferido que ela tentou lidar com toda a situação de modo a garantir a sua sobrevivência, em um mundo em que estava sozinha e era vista apenas como um objeto. Outra curiosidade é que foi suprimido o depoimento da mãe da mulher, presente no conto, que advogava em favor do valor de sua filha. (KAMIR, 2000)

Anderson cita a observação de Janice Matsumura de que no Japão dos anos de 1950, o estupro só era socialmente significativo quando manchava a honra de um homem, o qual deveria ter impedido que isso ocorresse. (JANICE, apud ANDERSON, 2016) Tendo em conta essa conjuntura, não é de se estranhar que não seja dada mais a importância a esse acontecimento no tribunal.

O lenhador seria em teoria o testemunho menos interessado, por isso existe a possibilidade de ser mais fiel aos fatos, porém não é possível que ele seja lido assim. Ainda que por último, Kurosawa se preocupou em colocar a figura do ouvinte que, crítico, o acusa de mentir e desmascara seu roubo da adaga, que diz não ter sido a arma que matou o samurai, e também a sua vergonha por não ter impedido que toda a tragédia acontecesse.

Anderson considera que o efeito Rashomon não é só sobre uma diferença de perspectiva. Ele ocorre principalmente quando essas incongruências nos relatos emergem de uma combinação da falta de evidência para afirmar ou desqualificar 
uma versão da verdade, somada à pressão social de se chegar a uma conclusão sobre o que de fato ocorreu. (ANDERSON, 2016)

Podemos assim concluir que, quando aqueles que passaram por um determinado acontecimento são de alguma forma levados a narrá-lo, os detalhes que focalizaram, a sua subjetividade, percepção e memória vão influir em sua narração. Mas a verdade de um testemunho só será relativizada quando for ouvido um outro que mostre incongruência em relação ao primeiro. Quando não houver a possibilidade de chegar a uma conclusão sobre o ocorrido configura-se o efeito Rashomon. Contudo, a ambiguidade não precisa ser um problema, pode ser uma escolha narrativa. No caminho da busca por um fechamento de sentido estão as diferentes versões.

\subsection{Ponto de Vista $x$ Plano Ponto de Vista}

O presente estudo busca pensar as múltiplas perspectivas dentro de obras audiovisuais, sendo assim é preciso elucidar a diferença entre o ponto de vista da narrativa, que se refere à visão que cada personagem tem sobre um acontecimento, e a forma visual com que é construída a história que revela essa visão. Um componente importante para a construção cênica da narrativa é o plano.

O plano é construído pelos frames, recortes das cenas que aparecem na tela. É o ponto de vista através do qual o público vê a ação, ou seja, a história que está sendo contada. A visão que o público vai ter sofre a influência do ângulo e do movimento da câmera, além da composição.

O ponto de vista de um plano poder ser onisciente, corresponder ao de um personagem específico ou de um grupo. Quando a câmera é onisciente a impressão que se tem é que ela é neutra, apesar de não podermos dizer que é objetiva, pois seu enfoque se dá a partir do desejo de um diretor. A câmera subjetiva é aquela que mostra o ponto de vista de um personagem e a de grupo funciona de modo semelhante, mas abrange um conjunto de personagens ao mesmo tempo, em lugar de um único indivíduo. (WIEBE, 2010)

O ponto de vista subjetivo é também chamado de plano ponto de vista (PPV ou POV, sigla do termo em inglês point-of-view shot, que também é correntemente usada nos roteiros, mesmo nos escritos em português). Nesse plano, a câmera 
assume a posição do sujeito, de modo a mostrar o que o personagem está vendo. Em geral, ele é constituído por dois planos. Um primeiro plano mostra o personagem e percebe-se que ele está vendo algo (plano A). Um segundo plano mostra o que o personagem está vendo (plano B).

Edward Branigan considera que o PPV é constituído por seis elementos. No plano A (plano em que o personagem olha) temos como elemento 1 o ponto no espaço em que o personagem está situado e como elemento 2 o olhar do personagem para um objeto (para algo ou alguém), que, em geral, está fora do plano. Entre o plano A e o plano B, temos o elemento 3, que corresponde a uma transição, dado por uma continuidade temporal ou simultaneidade. No plano B (plano em que se revela o que está sendo olhado), temos como elemento 4 o posicionamento da câmera, que corresponde ao ponto no espaço definido pelo elemento 1, voltado na direção correspondente ao olhar do personagem (elemento 2), e como elemento 5 , o objeto para o qual se olha. Os planos A e B possuem em comum o personagem, que Branigan considera como elemento 6. O espaço/tempo dos elementos de 1 a 5 são justificados ou indicados pela presença e percepção desse personagem. Esses seis elementos correspondem, respectivamente, às seis unidades de representações clássica: origem, visão, tempo, enquadramento, objeto e mente. O autor argumenta que, embora isso pareça trivial, qualquer alteração em qualquer um desses elementos subverte ou desestabiliza o PPV. (BRANIGAN, 2005)

Desestabilizar o plano ponto de vista pode ser um recurso cênico. Branigan cita alguns exemplos em que cada um desses elementos foi subvertido (BRANIGAN, 2005):

Em $O$ ano passado em Marienbad, de Alain Resnais (1962), a cena de abertura mostra cinco personagens olhando simultaneamente em diferentes direções. Em seguida, são mostrados diferentes contraplanos, incluindo planos pontos de vistas que desorientam o público quanto ao desdobramento espacial da cena. Essa desorientação se dá por não conseguirmos estabelecer quem é o elemento 1 de cada plano ponto de vista.

A falta de clareza no elemento 2 pode se dar por não sabermos se de fato o personagem está olhando algo. Indícios que reafirmam o olhar são movimentos dos olhos, da cabeça ou do corpo, uma fala, um som fora de campo, entre outros. 
Podemos criar uma estrutura divergente em uma transição (elemento 3). No plano A, um personagem pode olhar em uma festa para um canto da sala e, no plano B, a sala ser mostrada em um momento anterior ou posterior à festa. Essa transição de planos divergente denota uma lembrança ou uma antecipação.

Um exemplo de subversão do elemento 4 (posicionamento da câmera) é optar por um movimento de câmera subjetivo. Em Pinóquio, desenho de Walt Disney, por exemplo, a câmera salta, acompanhando o movimento do grilo falante e sua visão. Algumas pistas secundárias podem ajudar na orientação espacial quando, no plano A, por exemplo, um personagem olha por um buraco na parede e, no plano B, vemos uma nova cena emoldurada pelo buraco; quando um personagem vira de cabeça para baixo no plano A e, o plano B aparece de cabeça para baixo; quando vemos partes do corpo dos personagens, sua sombra ou imagem no espelho; para citar apenas algumas das inúmeras possíveis pistas secundárias.

O elemento 5 revela o objeto visto pelo personagem. Pode ser que este objeto já estivesse em parte ou por inteiro no plano A. Nesse caso, o elemento 5, no plano B, mostra um novo ângulo e/ou uma nova distância para o objeto. Quando o objeto não é revelado no plano B e é mostrado, por exemplo, outro objeto na cena subsequente, e não aquele para o qual o personagem olhou no plano $\mathrm{A}$, há uma quebra na narrativa.

O elemento 6 é o personagem, responsável por justificar a conexão entre os outros 5 elementos, assim prevê-se que ele esteja em condições normais, mas se ele, no caso, estiver em um estado de consciência alterado? Estando bêbado, drogado ou doente, a câmera pode apresentar-se desfocada. Pode ser também que ele tenha um problema de vista, e, assim, uma carta movimentada em sua direção ganhe e perca foco, de acordo com a distância.

A passagem da câmera do plano A para o plano B representa uma passagem de uma câmara onisciente e voyerista para uma câmera subjetiva e pessoal. É possível também criar uma relação de plano ponto de vista ao contrário: primeiro mostrar algo e, no plano seguinte, mostrar que alguém viu esse algo. Esse seria o plano ponto de vista descoberto.

Temos também outras possíveis variações de plano ponto de vista que Branigan denomina como (BRANIGAN, 2005): 
- Fechado: quando volta para o plano A novamente após mostrar o plano B (mesmo que seja revelando o plano A na repetição em um ângulo ou distância de câmera um pouco diferente).

- Retardado: quando, por exemplo, um personagem vê algo, outro percebe que ele viu e quando este olha para o local, já é tarde demais. Ao contrário, um personagem pode ter uma visão prematura, ou seja, anterior ao que seria um plano reação ao olhar para um objeto que ele ainda não viu. Por exemplo, quando assustado um personagem ouve ruídos e busca de onde eles vêm e nada vê. Essa reação poderia já ser condizente ao que está por vir. Branigan também cita o exemplo de Tubarão, de Steven Spielberg, em que o animal só é de fato visto muitas cenas após terem sido mostradas somente as reações de suas vítimas.

- Aberto: quando nunca vemos o objeto do olhar, podemos ouvir seu som, ver seus sinais, mas não o vemos em específico.

- Contínuo: quando um personagem olha para um mesmo objeto várias vezes ou para vários objetos. Esses objetos costumam ser apresentados em cortes sucessivos ou por movimentos subjetivos de câmera.

- Forjado: não é exatamente o ângulo do plano ponto de vista, mas é um ângulo que permite uma visão melhor da cena para o público e que consegue se passar por um PPV.

- Múltiplo: quando vários personagens veem o mesmo objeto. Quando um mesmo plano ponto de vista é oferecido para mais de um personagem sua estrutura costuma ser menos subjetiva, fazendo uso de um ângulo que deixe um pouco dúbio seu elemento 1, a ponto de poder servir para os dois.

- Incrustrado: quando a estrutura presente no ponto de vista de um personagem está contida na estrutura de um outro. Um personagem olha para um outro que olha para algo que o primeiro personagem não consegue ver.

- Recíproco: quando é possível alternar os pontos planos de vista, por exemplo em uma conversa entre dois personagens. (BRANIGAN, 2005) 
Godard dizia que o corte do plano ponto de vista era o corte mais natural presente nos filmes, pois quando o personagem olha para fora do plano, naturalmente temos a motivação de ver o que é que o personagem está vendo. (SCHNITZER, 2016)

Como vimos anteriormente, um plano ponto-de-vista também pode representar o olhar de um grupo de personagens. No filme de Hitchcock $O s$ pássaros (1963), a mesma mecânica que aconteceria em uma cena com o ponto plano de vista de um personagem, acontece com um grupo. Um grupo de pessoas está dentro da loja de conveniência de um posto de gasolina. Vemos, no plano A, o grupo de pessoas olhando para algo e vemos, no plano B, que esse algo é a gasolina vazando. A cena alterna os planos $\mathrm{A}$ e $\mathrm{B}$, e quando volta para $\mathrm{A}$, vemos ganhando destaque no grupo a personagem principal, Melanie. A visão do grupo e da protagonista é da gasolina indo para os pés de um homem que faz um gesto de pegar um isqueiro para fumar. $\mathrm{O}$ grupo tenta avisar, mas o novo plano B mostra que é tarde demais, tudo está incendiado. Um novo plano ponto de vista de grupo é utilizado, dessa vez, o de um grupo de pássaros. É apresentado um plano aéreo do que parece ser um ponto de vista onisciente do posto pegando fogo, mas, ao ver alguns pássaros entrando em cena nesse plano, percebemos que se trata de um plano B dos pássaros, que também possuem planos ponto de vista nessa narrativa. (WIEBE, 2010)

Os planos pontos de vista podem ajudar no ato de fazer com que o público se sinta na pele dos personagens, trazendo também pontos planos de vista incomuns, como os de cenas espaciais. No caso de robôs ou alienígenas, esses planos podem ser um recurso para mostrar as diferentes formas com que eles veem nosso mundo, em lugar de falar sobre isso. Pode-se fazer uso das distorções para demonstrar os estados de consciência alterados. No caso do Tubarão de Spielberg, de que falamos anteriormente, foi decidido adotar o ponto de vista do tubarão por questões técnicas: se ele fosse mostrado ficaria tosco, pois não era muito bem feito. Mas o resultado dele não ser visto, apenas os seus feitos, o tornou ainda mais aterrorizante. Há filmes de terror que fazem uso da câmera subjetiva, a partir do olhar do atacante, até para não se saber quem é ele, assim aumentando o estado de alerta da audiência. Os PPVs também podem ser utilizados como ferramentas para criar empatia entre público e personagem. (SCREENPRISM, 2017) 
Até objetos inanimados podem ajudar a contar uma história com seus planos pontos de vista. Em Breaking Bad e Better Call Saul, muitos dos atos ilícitos praticados são vistos a partir do ponto de vista de objetos como cofres, máquinas de lavar, lixeiras, privada, porta malas e até de um aspirador em pó, únicas testemunhas das contravenções dos protagonistas. (SCREENPRISM, 2017)

Ainda que seja possível explorar vários caminhos interessantes fazendo uso dos planos ponto de vista, o recurso não é bem aceito quando usado sem parcimônia e, principalmente, quando se restringe à câmera subjetiva, não demonstrando o que corresponderia ao plano A. Desde a A dama do lago, de 1947, até Hardcore Henry, de 2015, a filmagem que só revela o ponto de vista do protagonista gera estranheza e se mostra cansativa. O público de A dama do lago achou muito estranho todos os personagens ficarem olhando diretamente para a câmera o tempo todo. Hardcore Henry esteticamente se parece a um first person shooter game ${ }^{23}$, com a diferença de que você não controla o personagem. (SCHNITZER, 2016) (SCREEN PRISM, 2017)

Explorar diferentes planos enriquece o visual da história. O Homem Aranha, por exemplo, intercala momentos de câmera onisciente e de planos ponto de vista na mesma cena. Essa alternância permite, a todo momento, mostrar o entorno e a destreza do personagem se movimentando no espaço, ao mesmo tempo que tem momentos em que a audiência fica imersa no plano da ação a partir do olhar do herói.

Analisaremos as séries que serão objeto de estudo para entender se o plano ponto de vista foi utilizado para narrar o ponto de vista dos personagens protagonistas e, em caso positivo, de que forma.

${ }^{23}$ First person shooter games são jogos em que você acompanha o plano ponto de vista do personagem principal, como o clássico jogo de tiros Doom. 


\section{Ilusão biográfica e ação da memória em The Affair}

\subsection{Uma narrativa composta por diferentes perspectivas}

Ao longo dos capítulos anteriores, demos alguns spoilers sobre a série que vamos tratar aqui: The Affair (2014-2019), dos criadores Sarah Treem e Hagai Levi, produzida para o canal norte-americano Showtime e, posteriormente, também exibida pela Netflix. Como vimos, a série retrata visões da história do amor extraconjugal dos personagens Noah Solloway e Alison Bailey, e de seus respectivos conjugues, Helen e Cole. Primeiramente, vamos nos centrar na primeira e segunda temporadas, pois estas encerram um ciclo completo, em que os personagens são convidados a narrar sobre acontecimentos que ocorreram dois, três anos antes. E, posteriormente, faremos algumas observações sobre a terceira e a quarta temporada, que incluem também novos personagens. A quinta temporada encerrou a série em 2019, mas não tem data prevista de estreia no Brasil e não foi vista, nem será abordada. Foi uma temporada bastante controversa ao criar um salto temporal que apresenta, Joanie, filha de Alison, já adulta, sem a presença dos personagens Alison e Cole, cuja história é entrecortada com as perspectivas de Noah e Helen.

A narrativa da série entrelaça tempo presente e tempo passado, sendo este revelado pelo relato (flashback). O que vemos na tela é sempre a reconstrução dos fatos, sob a ótica de um dos personagens. Em geral, essa perspectiva é relativizada pela visão de outro personagem, produzindo uma dissonância que se mantêm indissolúvel e se torna parte da mecânica narrativa da série.

Essa dissonância persistente denota a realidade como construída por nosso imaginário, a partir de nossa perspectiva, e não como um valor concreto. A série nos passa a mensagem de que a mudança de um referencial é capaz de alterar toda a equação: que as histórias mudam dependendo de quem as conta.

Na Primeira temporada (2014), os episódios são divididos em duas partes. Cada uma revela o ponto de vista ou de Noah ou de Alison. Em geral, o de Noah vem primeiro. Em alguns episódios, o mesmo intervalo de tempo é relatado nas diferentes perspectivas, já em outros os relatos se complementam como recortes temporais consecutivos. Na segunda temporada (2015), a divisão em duas partes se 
mantém em praticamente todos os episódios, porém também temos acesso às visões de Helen e Cole.

Desde o princípio, temos como pano de fundo da série uma investigação criminal que se passa no tempo "presente", em que Noah e Alison, separadamente, prestam testemunho sobre um crime, que é entrelaçada com os flashbacks das memórias desses personagens.

Por se tratar de uma narrativa claramente subjetiva e por vezes escutarmos, nessas duas primeiras temporadas, os personagens falando sobre si, podemos ser tentados a considerar que se trata de uma narrativa com o ponto de vista de primeira pessoa. No entanto, talvez seja mais preciso enquadrá-la como uma narrativa com um ponto de vista de terceira pessoa limitado, pois acompanha apenas a perspectiva desse protagonista: só temos acesso ao que ele recorda. O personagem sempre está em quadro, mas, em geral, o vemos em uma visão de terceira pessoa, contando com alguns planos ponto de vista, usados principalmente para pontuar os momentos em que Noah e Alison se encontram ou se observam. A narração que ouvimos, apesar de às vezes parecer, não nos é direcionada. Ela faz parte do que os personagens falam para o detetive durante uma investigação, tendo-se em conta que, muitas vezes, a própria imagem do flashback que aparece recuperando a lembrança dos personagens a contradiz. Essa imagem seria, a rigor, mais fiel ao que os personagens recordam ter acontecido, pois não tem como objetivo encobrir nenhum possível crime. Convém destacar que nem tudo que eles lembram, eles narram ao investigador.

Tendo como base a definição de Branigan, os tipos de planos ponto de vista utilizados são, basicamente, o fechado, em geral após o plano do olhar do personagem vemos o objeto para o qual se olha e novamente o plano de seu olhar. Em alguns momentos, foi também usado o plano ponto de vista contínuo, em que o personagem olha várias vezes para o mesmo objeto. (BRANIGAN, 2005) É preciso destacar que esse recurso é usado com bastante parcimônia, diferentemente da série que analisaremos a seguir, Thirteen Reasons Why, em que seu uso faz parte da sua forma de narrar, sendo utilizado o tempo todo para realizar as costuras temporais.

No primeiro capítulo, a narrativa se inicia com Noah nadando em uma piscina. Ele resiste às insinuações de uma mulher, revelando que é casado. Chega 
em sua casa para encontrar sua mulher que ainda dorme e organizar a saída com toda a família de quatro filhos para a casa dos sogros na praia. Os primeiros minutos da série apresentam o mundo comum de Noah, mostrando sua dinâmica familiar e seus valores. Prontamente, irrompe nessa introdução um voice-over que agradece sua presença, chamando-o de Senhor Solloway. Na imagem, vemos o olhar de Noah para sua família, em seguida, seu plano ponto de vista da família saindo de casa para viajar com a imagem em uma velocidade não realista. Volta-se para o plano de seu olhar e novamente para a imagem da família descendo em uma velocidade realista, mas este já não é um plano ponto de vista, pois ele próprio está em cena. Vemos em destaque sua filha mais velha olhando pare ele e ele para ela, ao mesmo tempo que seu interlocutor lhe pede para que conte como começou toda essa confusão. Ela está de óculos escuros e responde aos cumprimentos dele de maneira um pouco indiferente. O voice-over de Noah pergunta especificamente o que o investigador quer saber. Este responde que aquilo que ele considerar relevante, perguntando se ele estava feliz com sua vida. Noah diz que estava se sentindo bem, tinha filhos saudáveis, uma esposa linda e que sua vida estava quase perfeita. A imagem revela que a situação não era bem essa. Vemos que o filho mais velho, Martin, está com vários problemas, inclusive o assusta fingindo suicídio. Noah o repreende, mas decide não contar o ocorrido para o resto da família. O interrogador lhe pergunta se ele se lembra da primeira vez em que viu Alison. Ele diz que como se fosse ontem e vemos seu plano ponto de vista. Quando o investigador lhe pergunta o que ele viu primeiro nela, ele diz com uma certa agressividade que claro que o seu rosto, mas seu plano ponto de vista o desmente: a imagem vai debaixo para cima, revelando, parte a parte, todo o corpo de Alison. Com isso, percebemos que a narração de Noah não é digna de confiança. Posteriormente, quando a cena se revela pelo ponto de vista de Alison, vemos uma imagem diferente à de Noah, colocando em xeque as representações visuais.

Pelo embate entre as perspectivas de cada personagem e a impossibilidade de eleger um ou outro como mais próximo do que poderia ser considerado a realidade, ambos se tornam narradores não confiáveis, pois não se tem nunca certeza do que ocorreu. Não é possível tomar nada como verdade e o questionamento se torna um hábito constante na espectatorialidade da série. 
Diferentemente de ficções em que as ações dos personagens são transcritas em um tempo simultâneo ao acontecimento, com o frescor do cotidiano, a narrativa, por ser construída pelas lembranças, sofre alterações de acordo com a seletividade e as distorções próprias ao processo de rememoração.

Assim como em Rashomon, a imagem em flashback não mostra uma realidade objetiva dos acontecimentos. A realidade pode ser construída de maneiras diferentes, a partir da subjetividade de quem a vê, como é o caso central em The Affair, ou a partir da corrosão da verdade, pelo interesse próprio do narrador, caso de Rashomon.

É a investigação do crime que rompe com o tempo presente, convocando as narrativas do passado em busca de alguma pista que revele algo sobre o mortal acidente que, a princípio, só sabemos ter ocorrido após um vago casamento.

Esse tempo "presente" corresponde ao tempo da experiência de relatar. O investigador faz perguntas sobre eles, inclusive sobre o caso extraconjugal dos dois. É a partir desses relatos, constantemente divergentes, que o público conhece a história. Assim, esses dois tempos cronológicos se entrelaçam: o tempo do relato e o tempo da experiência que está sendo relatada. A série pode servir de ilustração para o pensamento de Santo Agostinho de que só existe um tempo: o presente que recordamos, o presente que vemos diante de nossos olhos e o presente que projetamos. Isso porque esses dois tempos cronológicos são presentificados: o presente que os personagens vivem e o presente que recordam.

Sempre que alguém recorda um fato passado, a compreensão é traduzida do tempo passado para o instante no qual se recorda. (SARLO, 2007). Convém lembrar que, apesar dos personagens não serem seres humanos reais, cabe que tenhamos em conta a dinâmica de construção de história de vida e a operação da memória, pois o texto é construído tendo em conta esses fenômenos.

A narrativa do tempo do "acontecimento" começa, como dissemos anteriormente, quando Noah e sua família vão para a cidade litorânea de Montauk passar as férias de verão na casa dos pais de Helen, sua esposa e namorada desde os tempos de faculdade. O pai de Helen é um autor de renome literário, que já teve romances transformados em filmes, sendo ainda responsável por pagar parte das despesas familiares. Noah atua no mesmo segmento de seu bem-sucedido sogro, 
tendo acabado de lançar seu primeiro livro, porém por uma editora sem muito prestígio, já que é um autor desconhecido. É também professor do Ensino Médio, trabalho com o qual tenta se sustentar. O primeiro livro não foi um sucesso de vendas, mas garantiu um adiantamento para a escrita de um segundo, a ser escrito nessas férias. Na entrada da cidade de Montauk está a lanchonete Lobster Roll, onde a família Solloway decide almoçar e onde Alison trabalha como garçonete. Alison tem problemas em superar a perda do filho, Gabriel, fato que interfere em todas as esferas interpessoais de sua vida, inclusive no relacionamento com o marido Cole Lockhart que, junto a seus irmãos, administra o rancho da família e mais outros negócios mais clandestinos.

No lugar de uma narrativa única, encontramos sempre relatos que expressam diferentes pontos de vista. Como já mencionamos, na cena da lanchonete em que Alison e Noah se conhecem, ambos se recordam que salvaram a filha de Noah. Em um primeiro momento, ouvir as duas histórias faz parecer que um dos dois está mentindo, mas entendendo a narrativa como passível de ter sido reconfigura pela construção da memória, podemos entender que essa é a legítima forma com que cada um se lembra do fato. Como vimos, no capítulo 2, para mentir é preciso que se tenha a intensão de dizer algo que se sabe não ser verdade e parece não ser esse o caso que propicia as divergências na narração. As diferenças presentes nos relatos falam mais sobre um senso de visão do que inscrevem um debate sobre o que é verdade ou o que aconteceu realmente, ainda que, em alguns momentos, possamos inferir pela palavra de outros quem poderia estar mais perto de uma realidade pretensamente objetiva.

A memória é seletiva, nem tudo fica gravado. A memória sofre flutuações em função do momento em que é articulada e as preocupações do momento podem afetar sua estruturação. O que a memória grava, recalca, exclui ou relembra é resultado de um trabalho de organização. (POLLAK, 1992) A memória tenta sempre buscar a coerência e, assim, na tentativa de encadear os fatos em uma ordem cronológica também pode causar distorções.

Outros elementos visuais contribuem para ressaltar as diferentes visões. Alison é representada com os cabelos soltos, em roupas muito mais curtas e sensuais na visão de Noah do que em sua própria visão. Helen também é vista por ambos de maneira diferente. Noah usa em sua versão uma T-shirt verde com uma camisa 
social xadrez acinzentada por cima e na de Alison só uma elegante camisa social quadriculada verde.

Figura 1 - Alison na visão de Noah e em sua própria visão
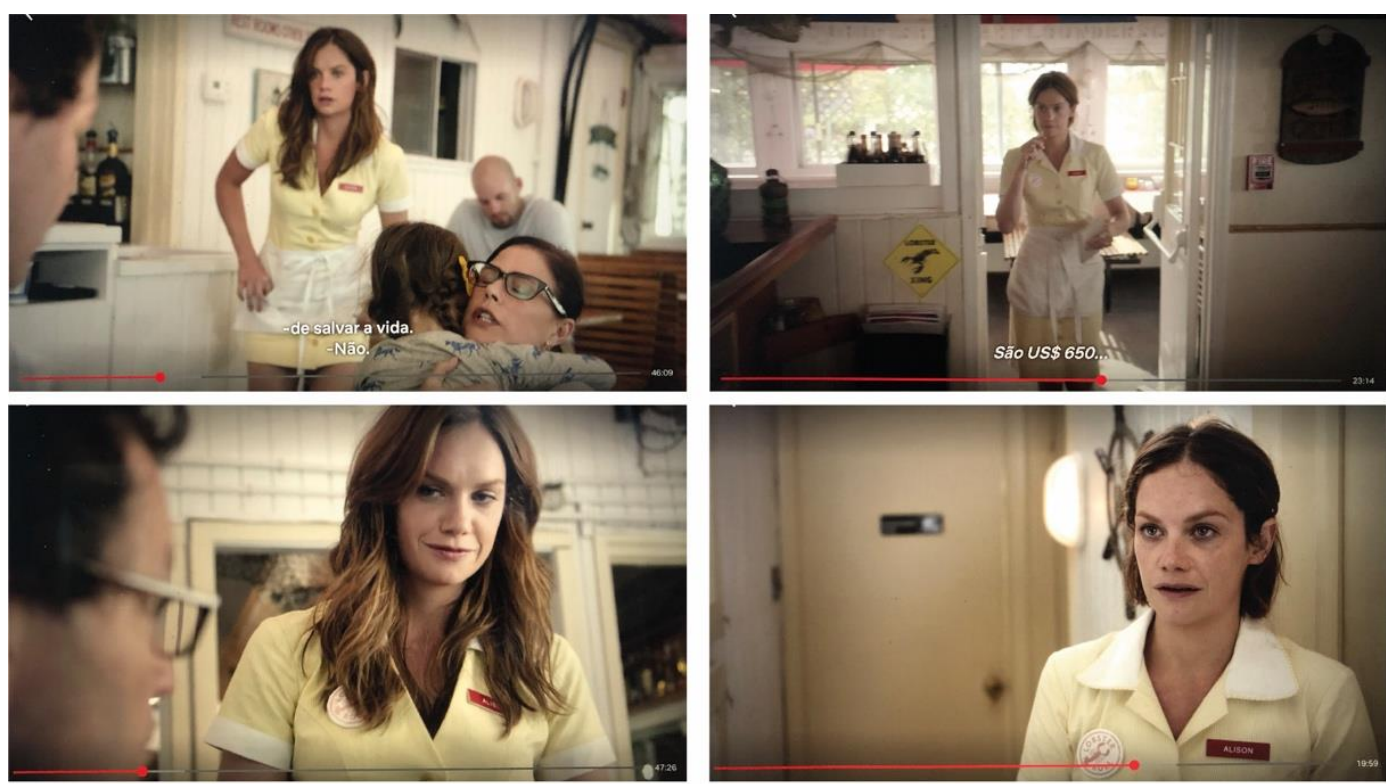

Alison por Noah

Alison por Alison

Figura 2 - Noah visto por ele mesmo e por Alison
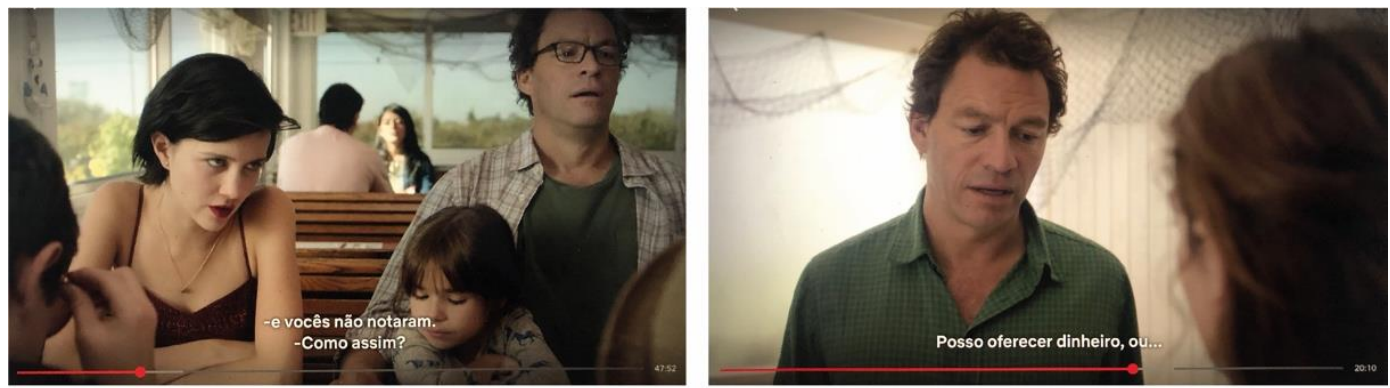

Noah por Noah

Noah por Alison

Figura 3 - Helen vista por Noah e por Alison
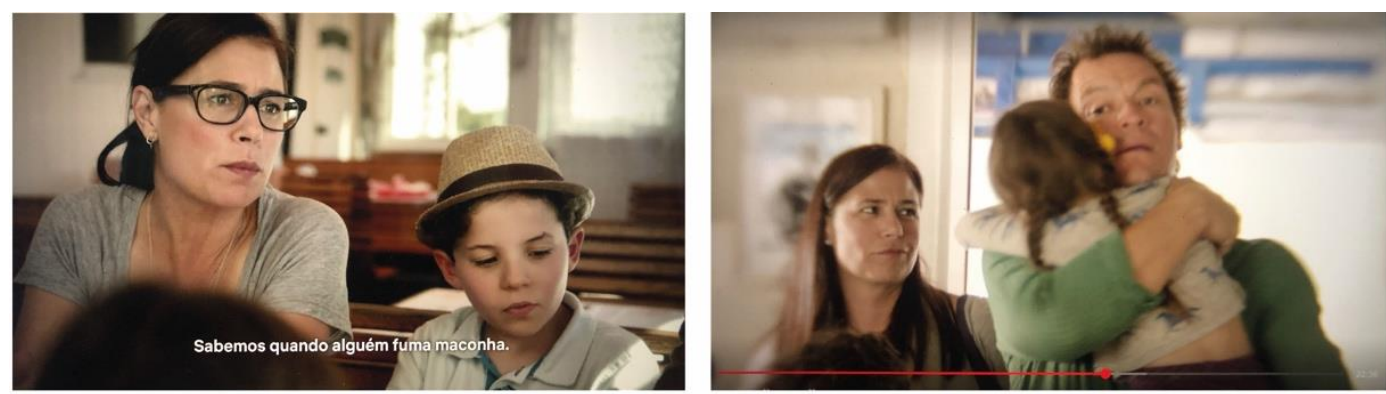

Helen por Noah

Helen por Alison 
Em geral, a mudança de roupas entre os relatos é muito frequente e se mantém constante em todas as temporadas vistas. Até o vestido amarelo que Alison usa no casamento que ocorreu no dia do crime, que Noah diz se lembrar por ter sido elogiado por mais de uma pessoa, é totalmente diferente ao da lembrança dela, que se assemelha mais ao que é mostrado na câmera de vigilância. Possivelmente porque ela conhece melhor suas próprias roupas do que ele.

Figura 4 - Vestido de Alison por Noah, por ela e pela câmera de segurança

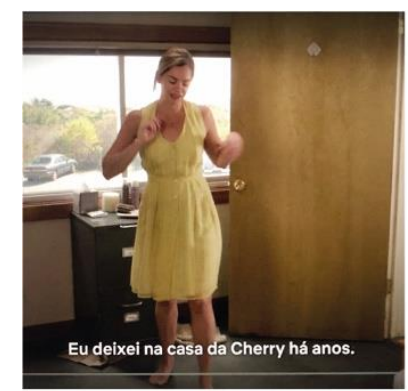

Vestido por Noah

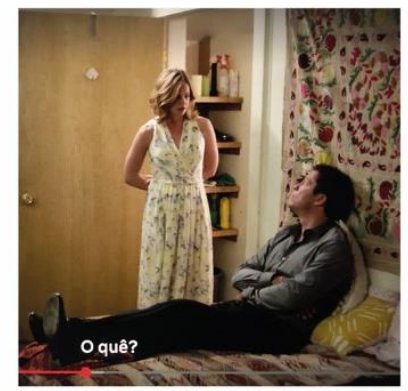

Vestido por Alison

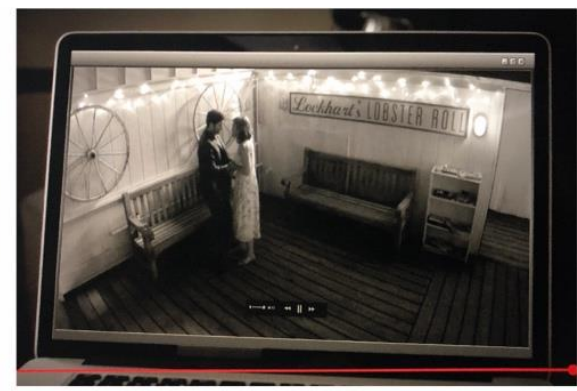

Câmera de segurança

Segundo o pesquisador Michael Pollak, a memória tem três vetores: acontecimentos, pessoas e lugares. (POLLAK, 1992) Podemos ver que as representações das lembranças, na série, operaram com distorções em todos esses três vetores. Cenas foram lembradas com acontecimentos em ordens distintas, em lugares diferentes e com a presença de diferentes pessoas. Essas mudanças não interferem tanto no sentido da narrativa de cada um, mas refletem a dinâmica de rememoração. Iremos posteriormente falar mais sobre a ação da memória, mas por hora analisaremos outro fator de extrema relevância para a diferenciação dos relatos: a subjetividade e a operação de construção de si, que também ocorrem no processo de construção de uma narrativa que corresponde a uma história de vida.

\subsection{Relatos, identidade, história de vida e ilusão biográfica}

Como dissemos anteriormente, são os relatos dos personagens que constituem o mecanismo narrativo da série. Assim, tudo o que vemos na tela é uma representação de um acontecimento, a qual acompanha a subjetividade do personagem e a forma com que ele reconstrói sua trajetória biográfica. 
Segundo o filósofo Paul Ricoeur, a vida é um tecido de histórias contadas, através das quais construímos nossa identidade e entendemos o mundo ao redor. Narrando, imprimimos ordem ao caos. (RICOEUR, 1994)

Quando narramos imprimimos sentido e, muitas vezes, para juntar acontecimentos em uma cadeia causal, acabamos por distorcer levemente os fatos. Detalhes são lembrados, outros omitidos e outros foram até mesmo esquecidos pela ação do tempo. Existe também o movimento natural de tentar justificar atitudes e construir uma imagem melhor de si no ato do relato. Quando Noah se lembra da cena em que sua filha engasga, como sendo ele o responsável por tê-la salvado, reconstrói a história que ocorreu em meio a um momento de caos e pânico de um modo que lhe confere o papel que se espera de um bom pai. Ele de fato estava na função de salvá-la, mas, posteriormente, vemos através da fala de Helen, que sem a ajuda de Alison isso poderia não ter sido possível.

A vida é vista como uma história que transcorre segundo uma ordem cronológica, sendo assim, nela busca-se uma lógica. O princípio não é só o início em si, mas também uma razão de ser. O seu fim, não só o término, mas também uma finalidade, um objetivo. E nas etapas, entre um e outro, organizamos muitos dos acontecimentos em relações causais. A ordem cronológica que fazemos é também uma ordem lógica (BOURDIEU, 1996), a qual opera de modo semelhante à narrativa ficcional que, seguindo a lógica aristotélica, possui começo, meio e fim, e as ações dos personagens se desenvolvem de forma causal, uma ação levando a outra.

Para Bourdieu, essa lógica constitui a nossa ilusão biográfica. A partir de um nome que nos é dado, o qual conecta todas as versões de nós mesmos em uma unidade, temos a ilusão de possuir uma história de vida. Essa história de vida conduz à noção de trajetória como uma série de posições sucessivamente ocupadas por um mesmo agente. (BOURDIEU, 1996)

O relato, tanto o biográfico quanto o autobiográfico, propõe uma ordem cronológica sucessiva para os acontecimentos. "O relato biográfico se baseia sempre, ou pelo menos em parte, na preocupação de dar sentido", imprimir um significado, extraindo uma lógica ao mesmo tempo retrospectiva e prospectiva, relacionando efeito à causa entre os estados sucessivos. A pessoa seleciona, em 
função de sua intenção, quais são os acontecimentos significativos a serem contados e estabelece entre eles as conexões para lhes dar coerência. Uma história de vida é um relato coerente, a partir de uma ilusão retórica. (BOURDIEU, 1996, p.184,185)

As formas como contamos as nossas histórias são particulares à nossa cultura e às nossas avaliações de importância. Algumas pessoas vão sempre falar mais da vida pessoal, outras do trabalho. Em tempos, ocasiões e para pessoas diferentes, os indivíduos podem contar de modo diferente os mesmos fatos e costurar de modo distinto as razões para o que aconteceu. (LINDE, 1993)

Bourdieu uso o termo biografia, mas temos que ter em mente que ele se refere a uma biografia oral. A definição da autora Charlotte Linde para uma história de vida é uma unidade oral de interação social, indicando como ela difere de outras construções do self, citando, entre elas, a autobiografia, a qual seria diferente, em primeiro lugar, por ser um documento escrito, cujas características atendem propósitos diferentes, e, em segundo, pelo fato de não ter que ser a todo tempo renegociada, no ato das relações interpessoais. (LINDE, 1993)

As histórias de vida expressam o senso de si, quem somos e como chegamos até aqui. Para poder existir no meio social, um indivíduo precisa do confortável senso de que é uma pessoa estável, coerente e, para isso, precisa constantemente revisitar sua história de vida. As histórias são criadas, negociadas e trocadas. Uma pessoa pode estar contando algo que aconteceu e ser criticada ou corrigida por outra pessoa. (LINDE, 1993) Uma mãe, por exemplo, pode falar de uma doença de um filho como se tivesse sido algo grave e desesperador e ser corrigida pela avó, que relativiza o relato como sendo apenas uma gripe. A mãe então pode concordar com a avó ou discordar, pois tem uma visão forte sobre o ocorrido, que não se abala com a correção.

Pollak defende que ninguém pode construir uma autoimagem (senso de si), isenta de mudança, negociação e transformação em função dos outros. Esta ideia converge com o pensamento de Linde de que a construção da identidade é um fenômeno que se produz nas relações interpessoais. (POLLAK, 1992, p. 13)

Stuart Hall também destaca a questão da diferença em relação aos outros como uma grande mobilizadora da identidade de alguém. $\mathrm{O}$ trabalho discursivo de construção da identidade envolve o fechamento e a marcação de fronteiras 
simbólicas. Essa construção é um processo nunca acabado, sempre em andamento, e pode ser sustentada ou abandonada. (HALL, 2000)

O que dizem Pollack e Hall é, em outras palavras, o mesmo que vimos descrito por Berger e Luckmann, no capítulo 2, sobre a construção da identidade no processo de construção social da realidade. É na dialética entre a nossa socialização primária e as socializações secundárias que formamos a nossa identidade. Nós nos apropriamos de modo subjetivo do que nos é passado de modo objetivo em processos sociais. Passamos, continuamente, por um processo de interiorização que nunca se acaba, em que trazemos a realidade pretensamente objetiva para nossa subjetividade, a interpretamos, objetivamos e exteriorizamos, tudo simultaneamente. Nossa identidade está sempre a ser socialmente confirmada, e quanto mais importante são para nós as pessoas, mais elas impactam nesse processo. (BERGER; LUCHMANN, 2004)

Se uma pessoa atua de uma forma levemente diferente da que é de seu costume, isso não chega a afetar sua noção de identidade. Mas se a atuação dessa pessoa se distancia muito do que se espera dela, isso abala sua construção de identidade. (LINDE, 1993) Bourdieu considera que o mundo social "tende a identificar a normalidade com a identidade, entendida como a constância em si mesmo". (BOURDIEU, 1996, p. 186)

Noah foi fiel à esposa por vinte anos. Sua identidade era a de uma pessoa fiel, que se esforçava para ser um bom marido e pai. Até aceitava passar as férias na casa do sogro para agradar a esposa.

Depois do caso com Alison, passa a ter dúvidas se agora é um infiel e se, por isso, vai continuar cometendo sempre atos de infidelidade ou não. A identidade é um trajeto sempre aberto à diferença e esta, quando ocorre, acaba por ressignificar as instâncias do auto reconhecimento. (ARFUCH, 2010)

Quando Noah, no início do primeiro capítulo, responde ao investigador que na época em que conheceu Alison era feliz e tinha a vida quase perfeita, vemos no decorrer dos episódios, por seus próprios relatos, que a sua autoestima estava baixa e que sua mulher não achava que ele fosse capaz de ser bem-sucedido como um escritor de romances, seu sonho. Noah se sentia diminuído, não só pela mulher, mas 
também pelos discursos do sogro e da sogra, apesar de rejeitar seus valores excessivamente burgueses.

Noah escreve seu segundo livro durante as férias em Montauk, uma visão romanceada de seu caso com Alison, sua relação com a família e os moradores da cidade. Ainda que sua pretensão tenha sido escrever um romance, a semelhança do livro com sua biografia (nitidamente baseado em fatos reais para todos), trouxe diversos conflitos para os retratados, ainda que por pseudônimos, que se intensificaram pela grande exposição quando o livro se tornou um best seller.

Sua identidade no mundo literário, após ter sucesso e por sua infidelidade, passou a ser a de um badboy. Também se somaram à infidelidade outras atitudes, como tentar bater em um crítico ou frequentar eventos com drogas e afins. Na busca de uma coerência interna e externa, e de auto aceitação para seus atos, Noah se compara ao pai e a personalidades. Nessas comparações, o personagem tenta operar por meio da diferenciação e proximidade da sua identidade à dos outros, delimitando e marcando fronteiras.

Segundo Ricoeur, na formulação de uma narrativa de identidade, o si olha para suas ações curtas, ao mesmo tempo que para as conexões de uma vida inteira. A identidade está sempre sujeita ao diálogo entre sedimentação e inovação. (RICOEUR, 1991)

Na sessão de terapia, Noah levanta questões do que é valor e sobre quem ele é. Essas perguntas estão ligadas à relação da identidade com a permanência no tempo. Quando comparamos uma mesma coisa a si mesma, em tempos diferentes, é que formamos a ideia de identidade e de diversidade. Para melhor entender isso, podemos recorrer aos conceitos de mesmidade (identidade do mesmo) e ipseidade (identidade do si) formulados por Ricoeur, segundo os quais ele vê a manutenção de uma identidade. Será que a traição modificou os valores de Noah? A interrogação esbarra na fronteira da ética. (RICOEUR, 1991)

No quesito do caráter, há uma sobreposição quase que completa entre os conceitos de mesmidade e ipseidade. O caráter é o conjunto das disposições duráveis pelo qual se reconhece uma pessoa, forma marcas distintivas em um ser humano, que pode se reidentificar como sendo o mesmo. Por isso, quando alguém tem um comportamento que não corresponde à sua disposição, as pessoas dizem 
que não é do caráter do indivíduo. O hábito que dura constitui um traço do caráter. Quando há uma inovação no hábito, ainda assim podemos ter uma identificação por ipseidade, desde que tenhamos o que Ricoeur chama de palavra cumprida, onde a fidelidade é dada pelo cumprimento da palavra, ainda que a pessoa mude seu desejo ou opinião (RICOEUR, 1991). Noah tenta entender o que nele permanece e qual é o seu desejo e se, apesar da infidelidade, ele poderia se considerar um homem bom. E, para tal, faz as suas reflexões "será que o fato do meu pai ter sido fiel fazia dele um homem bom? Apesar de ter sido um péssimo pai e marido?”.

Ele conta que está escrevendo um grande livro sobre a vida de um incrível herói de guerra chamado Bradley, que foi responsável pela conquista da Normandia. Glorifica seus feitos e conta que ele teve um caso com Marlene Dietrich. E se pergunta se esse caso anula suas conquistas, ou se as mesmas características que trouxeram seus feitos também o levaram ao caso extraconjugal. Pergunta "O que faz um homem ser bom?" e "Como vamos julgá-lo?”. Além disso, Noah percebe que os defeitos do personagem, que é imperfeito e egoísta, é que tornam o livro atraente.

A psicóloga fica interessada em como Noah acha que o tema se articula com a sua vida. A questão para ele é saber se é possível ser ao mesmo tempo um bom homem e um grande homem. Sua visão tem raízes na forma com que Helen lê os obituários: pelos casamentos duradouros e pelas virtudes, tais como monogamia, parceria e amor. Questiona se o general Bradley teria conquistado a Normandia se tivesse ficado trocando fraldas. Que talvez para isso ele tenha deixado a mulher infeliz. Se, ao olhar para o valor de suas conquistas, deixamos para trás o fato dele ter sido um bom pai ou não. No momento dessa cena, Noah se depara com o dilema de ser um bom marido e pai ou viajar, deixando a filha pequena e a mulher para trás, com o intuito de escrever um grande livro e ser livre para ficar com quem quiser. Confessa à psicóloga que a única coisa que não quer é ser desonesto, que não quer mentir, nem para ele mesmo, nem para os outros.

Noah questiona sua identidade e conduta: se apesar dos defeitos, do egoísmo, da infidelidade, de outras tentativas frustradas de infidelidade e da ausência familiar, ele ainda teria valores e o que significa ter valores. $\mathrm{O}$ autor da série parece inferir que sim, com a atitude de Noah, no final do último episódio da segunda temporada. No início do primeiro capítulo da série, um dos filhos de Noah, 
Trevor, lhe pergunta se, caso um avião com a família fosse cair e ele tivesse que perder uma pessoa, quem ele não salvaria e ele responde que a resposta é fácil: ele mesmo. Metaforicamente falando, nesse episódio é exatamente isso que ele faz, demonstrando que seus valores permaneceram acima da infidelidade e de outras atitudes controversas.

A memória, assim como a identidade, é sempre uma construção social. A experiência é o enquadramento de uma memória narrativa. Essa memória narrativa é que constitui o nosso sentimento de identidade, tanto individual, quanto coletivo.

Tanto a memória individual e a memória dos outros, quanto a identidade são valores disputados. Para Foucault, a identidade do sujeito é sempre construída pelo discurso. A posição do sujeito é o modo como o discurso posiciona o sujeito, a partir das relações de poder. O que Hall pensa que vai além desse conceito de Foucault é que nas dinâmicas culturais você vai produzindo fixações, assim o sujeito, de certo modo, pelo seu histórico de discursos anteriores, cria uma raiz em uma identidade, a qual é esperada que seja mantida, mas, uma vez que as identidades não são fixas, nada impede que mudem. (HALL, 2000)

A narração é sempre uma lembrança, uma rememoração pessoal do passado traduzida em linguagem. (HALBWACHS, 2016) O discurso, o enunciado, está sempre conectado a um ponto de vista, o qual é demarcado pela posição sócio histórica de quem o emite. Vimos que as divergências nos relatos podem ser fruto de uma diferente perspectiva e não denotam, necessariamente, que alguém está mentindo ou agindo de má fé. A mentira e a verdade dependem da intenção de se apresentar uma informação em desacordo ou acordo com o que se acreditar ser verdade. Mesmo que todos as testemunhas de um acontecimento atuem de boa fé, isso não significa, então, que a soma das partes necessariamente leve a um todo.

Assim, o investigador pode não chegar a ter uma visão próxima de uma realidade que se quer objetiva de um acontecimento, mesmo que todos digam a verdade.

Segundo Halbwachs, fazemos apelo ao testemunho para completar, fortalecer ou debilitar algum quadro que já formulamos sobre determinado acontecimento. Esse quadro pode estar ainda bem turvo. (HALBWACHS, 2016) 
Quando os relatos coincidem, a sensação de confiança e exatidão é maior. Mas, quando as divergências não conseguem ser negociadas ou refutadas, chegamos a um quadro de efeito Rashomon. Para fugir desse efeito e resolver o caso, o investigador irá confrontar as visões de cada um. Irá caçar no discurso o não-dito, o esquecido e o silenciado.

A terapeuta tem um interesse bem diferente do investigador criminal, que busca culpados. Para ela, interessa mais a visão de cada pessoa, para entender a visão de mundo do paciente. A construção do relato também difere em cada situação. Existem leis que culturalmente conhecemos a respeito de como adaptar o nosso relato para cada contexto. Enquanto, no primeiro caso, a relação discursiva segue a lógica da confidência, no segundo, tudo pode ser usado contra você. Na investigação, o objeto do discurso é uma apresentação pública, a oficialização de uma representação privada da sua própria vida, seja ela pública ou privada. (BOURDIEU, 1996)

Em ambos os relatos é preciso se preocupar com a cronologia e com tudo que seja inerente à representação da vida como história. As circunstâncias do interrogatório, a distância entre o interrogado e o interrogador, orientam o esforço de apresentação de si na construção do relato, ou melhor, da produção de si. (BOURDIEU, 1996)

A coerência é fundamental. Ela é uma demanda social e uma propriedade do texto. Deriva da relação entre as partes de fazer sentido uma com a outra e com o texto como um todo. É uma faculdade que temos facilidade em desempenhar, independente das pessoas estarem sendo sinceras ou não. (LINDE, 1993)

A questão da série é mais revelar como os personagens interpretam os acontecimentos, se lembram e reconstituem o que viveram, do que buscar uma verdade objetiva.

\subsection{O impacto da ficção na realidade dos personagens}

Os limites entre ficção e realidade se diluem todo o tempo, em várias camadas da narrativa, tendo efeito devastador na vida de vários personagens, principalmente de Alison e Cole. 
Ao ler as descrições da personagem que corresponderia a ela no livro de Noah, Alison começa a ter graves problemas com sua autoimagem. Apesar de ficcional, o fato das histórias serem bem próximas à realidade daqueles que as conhecem, amplifica a sensação de insegurança de Alison sobre si e sobre o seu papel na vida de Noah. A personagem começa a segunda temporada claramente perdida, tentando entender quem ela é fora de sua cidade natal e pergunta frequentemente a Noah o que ela representa para ele. Este se esquiva com respostas como "você foi a melhor coisa que me aconteceu" ou "você é minha musa".

No fundo, o que Alison queria era saber se ocupava algum lugar em sua vida que não o de amante e não viver apenas sob a sombra dele. Consegue um trabalho com os senhorios do chalé que os hospedam, Robert e Yvonne. Esse fato causou atrito com Noah, que considerou estranho ela estabelecer laços empregatícios com eles. Tudo se agrava quando Alison percebe uma mudança repentina nas interações com Yvonne, que começa a lhe tratar com imensa frieza e a criticá-la por usar roupas de menos. Por mais que ela não comente sobre o livro de Noah, Alison desconfia que essa possa ser a causa, suspeita confirmada quando Robert lhe diz que Yvonne devorou o manuscrito. Alison havia sido proibida por Noah de ler Descent $^{24}$, assim não sabia exatamente o que estava lá. Robert acaba confidente de Alison, revelando que o seu relacionamento com Yvonne também começou como um caso e lhe diz que ela não tem culpa do efeito que causa nos homens. $\mathrm{O}$ comentário não poderia cair-lhe pior: a imagem da figura sexy lhe pareceu imensamente perturbadora. O imaginário que Yvonne construiu sobre Alison, a partir da leitura do manuscrito, faz com que obrigue Robert a demiti-la. Ele o faz de uma maneira gentil, dizendo que ela não nasceu para ser assistente de alguém, mas Alison percebe que tudo isso é uma desculpa. Alison resolve ir até a casa de Yvonne conversar com ela sobre a demissão, mas encontra a casa vazia. O manuscrito de Noah estava sobre a mesa e ela cai na tentação de lê-lo. A leitura de Alison é acompanhada por um voice-over de Noah, que revela extratos do livro como: "Ela era sexy... a própria definição disso, a razão da palavra ter sido inventada" e "Nenhum casamento, não importa o quão forte fosse, poderia

\footnotetext{
${ }^{24}$ Uma curiosidade é que o livro está disponível para venda por ebook no site da Amazon, com os dizeres "The real best-seller author" e o nome Noah Solloway na autoria.
} 
sobreviver a ela". ${ }^{25}$ Alison se vê aos olhos de Noah como uma fantasia e como a representação de uma vadia. Sente que Noah não a compreende e enxerga além desse estigma. Faz as malas e vai procurá-lo na cidade, mas encontra Helen ao invés. Em sua visão, ela lhe pede desculpas dizendo que não teve a intenção de estragar seu casamento. Helen lhe responde que ela teve escolha e considera insinceras suas desculpas. Não sabendo para onde ir, Alison volta para Montauk.

Alison sofre com o olhar dos outros sobre si e acha que tem algo errado com ela. Noah repete inúmeras vezes a Alison que ela não é a personagem do livro, mas ninguém compra essa afirmação, nem mesmo ela. Ela volta para a casa onde está Cole, que não lhe vê dessa forma, a considera apenas uma mulher complicada.

Cole também resolve ler o livro de Noah após Oscar, dono do Lobster Roll, mencionar o papel de destaque de sua família. Ele e seus irmãos eram protagonistas e, ainda que fossem usados pseudônimos, quem os conhecia facilmente percebia que se tratava dos Lockhart. Em grande parte, as revelações correspondiam a realidade, inclusive quando mencionava suas atividades ilícitas. No entanto, havia uma parte que Cole considerou absurda e totalmente ficcional, referente a rixa entre sua família e a família de Oscar. Segundo o livro, ela se iniciou com um caso extraconjugal entre a avó de Cole e o avô de Oscar. Ao descobrir sobre o caso, o avô de Cole, Silas, mata a criança por eles gerada. Em resposta, o avô de Oscar amaldiçoa toda a linhagem dos Lockhart a terminar com os quatro irmãos. A família conversa sobre isso na mesa do Thanksgiving day e a mãe de Cole, Cherry, revela que a história é verdadeira. Isso é um choque para Cole que junta isso ao fato de ter perdido Gabriel, o aborto de Whitney (filha de Noah) do bebê de Scott e outro irmão e sua mulher terem perdido um bebê antes que nascesse.

Whitney aparece na casa de Cherry a procura de Scott, que foge dela e Cole se sente obrigado a levá-la para casa. No caminho, ela comenta como o pai tornou os Lockhart famosos e se recente dele não ter falado sobre ela, pensando que talvez fosse menos importante para o pai do que esperava que fosse. Não percebe o impacto negativo causado nas pessoas que ele retratou.

\footnotetext{
${ }^{25}$ Tradução da autora de: "She was sex... the very definition of it, the reason the word was invented" e "No marriage no matter how strong could survive her"
} 
No episódio 9, Alison diz a Noah o quanto sua representação no livro a ofendeu. Ele defende que ela serviu apenas de inspiração para a personagem, mas o final do livro, em que a amante é atropelada na estrada, demonstra o contrário: quando vislumbramos a visão de Noah desse fim, quem aparece atropelada na imagem é Alison. Ela não pode conciliar a ideia que que alguém que a ame possa pensar em um final onde ela seja destruída por ele próprio.

No mesmo episódio, também descobrimos que Luisa, já namorada de Cole, não pode ter filhos e isso reafirma para ele a maldição dos Lockhart. Luisa fica chocada por ele achar que o mundo gira em torno de sua dor. De volta à casa, Cole tem uma visão de seu filho morto e é tomado por um comportamento destrutivo, que o faz colocar fogo na casa consigo dentro.

Até quando o tempo presente se revela, vemos que Alison ainda tem problemas em achar seu lugar na vida de Noah. Ainda que naquele momento ela detenha o papel oficial de esposa, tudo segue turvo na relação com Noah. Ao esbarrar com um conhecido, advogado, descobre que ele está defendendo seu marido e que está sendo pago por Helen. Segue se sentindo a amante, uma intrusa que vive uma vida que de fato não é dela. Ou seja, se já não fosse difícil começar uma nova vida conjugal a partir de um caso, quando o mundo a vê como a personagem destruidora de lares de um best seller, essa tarefa se torna ainda mais hercúlea. A série, então, apresenta ainda mais essa camada além dos relatos, a representação romanceada dos acontecimentos, feita por Noah.

\subsection{Memória e esquecimento}

No início da narrativa do tempo do "acontecimento", Alison se atormenta cotidianamente com a lembrança da morte do filho, Gabriel. Basta abrir os olhos pela manhã para se deparar com a imagem do anjo de mesmo nome, tatuada nas costas do marido.

São as marcações de crescimento na madeira da sala, o baú de recordações, o bandaid do capitão gancho... muitos são os vestígios com os quais ela tem que conviver, mas, por outro lado, o que parece é que tudo o que ela queria era esquecer, pois não consegue conviver com essa dor: "...ele continua ali, longe e perto, espreitando o presente como a lembrança que irrompe no momento em que menos 
se espera ou como a nuvem insidiosa que ronda o fato do qual não se quer ou não se pode lembrar." (SARLO, 2007, p. 9) Lembrar ou não lembrar de algo não é algo sobre o qual cabe uma decisão. A lembrança pode vir, mesmo sem ser convocada. E é dessa forma que vem a lembrança de Alison.

Em um diálogo com Noah, em seu relato, ela lhe pergunta: "O que você vê em mim?”. Ele lhe responde com outra pergunta: "O que você acha que eu vejo?". Ela responde: "morte". A questão é tão presente em seu íntimo que, para ela, se confunde com sua própria identidade.

A morte do filho, para Alison, foi um elemento que reconstruiu a sua identidade e passou a balizar sua existência. Foi uma variação importante em sua história de vida, que lhe trouxe um fio condutor, um leit-motiv. (POLLAK, 1989)

Mas, apesar de não conseguir se esquecer do acontecimento da morte, vamos descobrir que ela não tem clara uma narrativa sobre como tudo ocorreu.

Sabemos que ela se sente culpada, e inclusive periodicamente se corta, como uma forma de se punir e tentar, de algum modo, aliviar a sua dor. Mas fica nitidamente em um estado traumático quando, após a descoberta de seu caso extraconjugal, a sogra se revolta e a acusa de ser de fato "a culpada" pela morte de Gabriel, discursando sobre o quanto foi tolerante por ter cuidado dela mesmo assim, dando a ela comida e banho enquanto ela tinha medo de água. Diz que, por ela, teria levado o menino para o hospital, mas que Alison imaginou que não era necessário. E, pela reação de desespero de Alison, percebemos como ela nem desconfiava que a sogra estivesse pensando isso dela.

Segundo Wieviorka, é um erro crer que o silêncio favorece a paz. Ele não faz mais que perpetuar a tirania dos eventos passados, favorece suas deformações e contamina a vida cotidiana. (WIEVIORKA, 1998)

Esse silêncio sobre o passado estava ligado à necessidade de seguir a vida adiante, depois da tragédia. A mãe de Cole, para preservar a nora, se calou, evitando lhe gerar o sentimento da culpa que considerava que ela deveria ter. Afinal, ainda que culpada, Alison era também vítima da perda de Gabriel:

Em face dessa lembrança traumática, o silêncio parece se impor a todos aqueles que querem evitar culpar as vítimas. E algumas vítimas, que compartilham essa mesma lembrança "comprometedora", preferem, elas também, guardar silêncio. (POLLAK, 1989, p. 6) 
Mas, a partir do momento que Alison trai Cole, a sogra considera que Alison deixou de merecer sua proteção e, então, o silêncio se converte em acusação. Sentindo, pela reação da sogra, que é mesmo culpada, faz um corte profundo na perna, o que a obriga a procurar seu médico. Tentando entender a motivação de Alison e percebendo as marcas de outros cortes, o médico inicia uma conversa com ela.

Para poder relatar seus sofrimentos, uma pessoa precisa, antes de tudo, encontrar uma escuta. (POLLAK, 1989) (WIEVIORKA, 1998) O médico era a sua escuta. Alison já havia conseguido comentar um pouco sobre a situação com Noah, mas foi a conversa com o médico e sua ajuda, junto à informação trazida pela sogra, que lhe permitiram de fato revisitar e rememorar o acontecimento.

Percebemos que ela não se lembrava ao certo do que aconteceu na noite em que o filho morreu, mas ao conseguir traçar uma narrativa a respeito do evento, percebeu que havia uma pequena chance de que o destino pudesse ter sido diferente, trazendo à tona um ressentimento com ela mesma e com Cole, que estava olhando a criança no momento em que o afogamento ocorreu. Quando ela chegou, ainda conseguiu fazer os procedimentos que pareceram salvá-lo, o menino pareceu apenas cansado, mas, depois que o pôs para dormir, ele nunca mais acordou.

A linguagem organiza o distanciamento daquilo que não pode ser posto à distância: "E é aí que intervém, com todo o poder, o discurso interior, o compromisso do não-dito entre aquilo que o sujeito se confessa a si mesmo e aquilo que ele pode transmitir ao exterior." (POLLAK, 1989, p. 8)

Como vimos, o livro de Noah também fez aflorar memórias subterrâneas na família Lockhart. Após Cole comentar sobre o absurdo que era a passagem que fazia menção ao seu avô, a mãe de Cole confirma o fato dele ter matado a criança, fazendo com que Cole acredite na maldição e passe a culpar o avô pela morte de seu filho Gabriel.

Existem nas lembranças de uns e de outros zonas de sombra, silêncios e nãoditos, mas também ocorrem eventos que trazem essas lembranças à tona.

Mesmo no nível individual, o trabalho da memória é indissociável da organização da vida social. (POLLAK, 1989) Com essa percepção, Alison tenta se afastar de sua vida social, a fim de conseguir viver sem seu sentimento de culpa. 
Deixa a cidade, a casa e o próprio marido, na esperança de que assim consiga seguir sua vida, sem a sombra da morte do filho.

Pela perspectiva de Halbwachs, esse raciocínio pode funcionar se ela conseguir cortar os vínculos com aqueles que com ela compartilham essa lembrança, ou pelo menos atenuar. $\mathrm{O}$ autor considera que perder o contato com aqueles que nos rodeiam em determinado período da vida pode contribuir para o esquecimento desse período, mas como, no caso, o evento é muito relevante, é bem difícil que possa ser simplesmente esquecido. (HALBWACHS, 2016)

A narrativa de The Affair persiste com voltas e reviravoltas, com encontros e desencontros entre seus protagonistas, sempre contadas através de diferentes discursos.

Podemos concluir que o fato de as memórias serem simultâneas não faz delas similares. Relatos distintos podem se complementar ou conduzir a uma dinâmica de relativização. O relato de uma história de vida será sempre negociado no intercâmbio com outras pessoas.

Na série The Affair, cada personagem constrói a sua colagem de lembranças e esquecimentos, e é a partir dessa pluralidade de relatos que vamos conhecendo mais sobre a história que está sendo contada. Essa colcha de retalhos nos permite criar um quadro dos acontecimentos, tendo em mente as diferenças entre as perspectivas, como não podia deixar de ser, uma vez que refletem um ponto de vista específico e sofrem a ação da memória.

As visões diferentes não significam que alguém está deliberadamente mentindo, mas que cada personagem interpreta os acontecimentos, se lembra e reconstitui o que viveu de forma diferente. A construção da narrativa da série acontece no entrelaçamento dos relatos de cada um, sem que se feche, a partir dessas linhas discursivas, nenhum sentido objetivo, sendo mantidos, sem juízo de valores, os pontos de vista diferentes para uma mesma história.

\subsection{Toda regra tem sua exceção - será?}

Praticamente toda a narrativa de The Affair apresenta uma cartela com o nome de um dos protagonistas, determinando que aquela parte corresponde à 
perspectiva desse personagem. Há raros momentos em alguns episódios que revelam um pequeno extrato de tempo presente/futuro sem apresentar essas cartelas. Seriam então esses momentos desprovidos de subjetividade?

Um único episódio nas quatro temporadas analisadas foge à regra de dividir sua duração com esse tipo de cartela: o episódio 9, da segunda temporada. Ao invés das cartelas por visão, ele usa cartelas de tempo. Ele se desenvolve quase por completo em um mesmo dia e entrecorta cenas protagonizadas por Alison, Helen, Noah e Cole. Essas cenas também não ficam restritas a uma única parte do episódio, sendo intercaladas. Em alguns blogs que fazem resumos dos episódios, seus autores consideraram que esse episódio ofereceu ao público uma visão mais objetiva da realidade desses personagens. Eu não havia tido essa impressão quando assisti a série. Ainda que eles não estivessem sendo apresentados com as respectivas cartelas, as cenas seguiam a mesma lógica de ter sempre seu protagonista presente, incluindo distorções que são claramente subjetivas, que irei descrever abaixo. Outra questão é que, particularmente nesse episódio, nenhum protagonista compartilha sua cena com outro, não tendo então, consequentemente, a possibilidade de uma mesma cena ser apresentada por mais de uma perspectiva.

O fato é que o episódio inovou na estrutura, mas se a imagem apresentada é ou não objetiva só pela ausência da cartela, me parece questionável. Caso essa tenha sido a intenção de seus autores, os recursos utilizados pela narrativa não corroboram para essa pretensa objetividade.

Seguimos tendo a imagem sofrendo a influência da subjetividade dos personagens em suas respectivas partes, tanto em seu plano ponto de vista como na imagem que revela a cena.

O dia em que se passa o episódio é um dia em que chega um furacão na região. O episódio começa ao meio dia, com Alison grávida ouvindo o noticiário e sentindo algumas contrações. Uma hora da tarde, Helen está em um restaurante esperando por um date marcado em um aplicativo, que não aparece, mas encontra Vik, médico que operou seu filho (futuro novo marido). Alison não consegue falar por telefone com Noah e vai sozinha para o hospital. A cartela de sete da noite mostra Noah em seu carro, acompanhado por sua publicitária, buscando, sem sucesso, por seu telefone, que vibra em algum lugar abaixo de seu assento. Ansiosa 
por entrar na festa, a publicitária o convence a achá-lo depois. Nessa festa, após conversar com o possível diretor de seu filme, ele se droga, bebe e trai Alison com a publicitária. Ela lhe indica um quarto para encontrá-la, mas nesse momento ele já está tão fora de si que começa a vagar maravilhado pela festa, que parece alheia à tempestade que já se apresenta. A imagem fica turva, com as luzes fazendo as movimentações naturais a uma visão alterada por entorpecentes. Isso se reflete não só em seu plano ponto de vista, mas em toda a tela, denotando uma clara subjetividade. A narrativa segue com ele entrando na água e observando duas garotas peladas se beijando. Ele fica parado observando-as e quando a que está de costa se vira, é sua filha Whitney, que o reconhece e berra. Seu berro parece também ser ouvido por sua mente alterada. Ele sai correndo da festa e tenta entrar no carro, contra o aviso de que a estrada estava fechada pela chuva. Nesse momento, vê as milhares de chamadas perdidas de Alison. Tenta dirigir de volta à cidade, mas ao tentar contornar o bloqueio encalha o carro e grita inúmeras vezes, caindo em si por suas atitudes. A cartela das dez da noite mostra Alison tentando adiar o nascimento da filha para não passar pelo momento sozinha. Às onze da noite, Cole e Luisa estão aguardando a forte tempestade passar, após tirarem da casa, que será vendida e derrubada, as coisas de Cole e também de Alison, que sabemos por que não apareceu. A voz de Luisa contando uma história para Cole aparenta estar mais baixa que o normal dos diálogos, dando a entender sua falta de atenção para ouvi-la, ainda que ele esteja a olhar para ela. Após ela lhe contar que não pode ter filhos, ele novamente ouve tudo o que lhe aconteceu com sua voz muito baixa, e assim percebemos que ele está só pensando que isso tem a ver com maldição, conforme lhe revela em seguida. Quando ela sai da casa saturada por ele achar que tudo gira em torno de sua dor, Cole começa a beber. A visão também se torna turva. Essa cena se entrecorta várias vezes com a cena de Alison gritando parindo. Esses gritos se mantêm no áudio da cena de Cole, totalmente desestruturado sentado no chão aos prantos, dando ainda mais dramaticidade à tempestade. Cole olha para fora da janela de vidro e, no meio da tempestade, vê ainda turva a imagem do filho Gabriel e ouve sua voz lhe chamando para entrar com ele no mar. Alison consegue ter o bebê, mas tanto sua visão quanto sua imagem estão levemente embaçadas. Após vermos Cole no meio da casa em chamas, a cena seguinte mostra Alison na calmaria segurando seu bebê. A médica diz que o pai finalmente chegou e pergunta se pode deixá-lo entrar. Ela diz que ainda não e olha para a criança se sentindo completa. 
Essa é a única cena que parece acontecer no dia seguinte e não é introduzida por uma cartela, apesar de ser claro que ouve uma elipse temporal.

Será que os autores, da mesma forma que criaram o jogo de colocar cartelas com os horários e a omitiram nessa última cena, que claramente não segue o tempo da anterior, omitiram as cartelas com os nomes dos personagens por já estarmos familiarizados com o jogo das perspectivas e, então a acharem óbvias?

Não sei a resposta para essa pergunta, apesar de claramente considerar que a subjetividade, de uma forma ou de outra, se manteve. O que posso afirmar é que houve uma quebra na estrutura ao entrecruzar as cenas protagonizadas pelos diferentes personagens.

\subsection{Estrutura narrativa}

Como dissemos anteriormente, a primeira e a segunda temporada juntas encerram um ciclo. A terceira e a quarta avançam a história, cada temporada formando o seu próprio ciclo. Todas elas possuem duas linhas temporais principais, com a rara presença de alguns flashbacks adicionais, portanto vou me ater a essas duas linhas. Os parágrafos abaixo, inevitavelmente, contêm spoilers.

Na primeira temporada (2014), temos como linha do tempo presente o tempo da investigação do atropelamento e morte de Scott. Nessa temporada, as conversas entre o detetive e Noah ou Alison, entram frequentemente como narração de sua respectiva parte, sendo a única temporada que contém narração. A segunda linha temporal, que corresponde à maior parte da narrativa, compreende o tempo entre o momento em que Noah e Alison se conhecem no Lobster roll até um encontro complicado que envolve a filha mais velha de Noah, Whitney, e Scott Lockhart (irmão de Cole), que se envolveram apesar de Whitney ser menor de idade. Whitney vai para o rancho da família Lockhart e quer ficar com Scott, mas, avisados por Alison, Noah e Helen vão buscá-la. Cole aponta uma arma para Noah, mas Alison consegue convencê-lo a não fazer nenhuma besteira. A linha temporal presente começa com o detetive colhendo os depoimentos de Noah e Alison sobre o crime e se encerra com os policiais batendo na porta do apartamento em que Noah, Alison e sua filha pequena, Joanie, estão morando e prendendo Noah pela morte de Scott Lockhart. 
A primeira temporada tem um evento específico que desencadeia a narrativa: a investigação criminal, que faz com que os personagens sejam obrigados a se lembrarem e a narrarem sua história de amor extraconjugal. A partir disso, acessamos visualmente suas lembranças, sendo construída essa dinâmica entre tempo presente e tempo da recordação. Nas outras temporadas, a dinâmica se mantém, mas sem que haja novos eventos impulsionadores da trama.

A segunda temporada (2015) tem suas duas linhas do tempo consecutivas às da primeira. A linha do tempo presente representa o julgamento de Noah, do momento em que é preso até o momento em que ele mesmo se acusa e vai para a cadeia. A linha do tempo passada, que ainda corresponde à maior parte da narrativa, seria a continuação da linha do tempo passada da temporada 1 , do momento em que Noah resolve morar com Alison, em um chalé para escritores, até o novo casamento de Cole com Luisa, após o qual ocorre o acidente de carro que mata Scott. A mesma dinâmica da primeira temporada se mantém, mas aos pontos de vista de Alison e de Noah, acrescentam-se os de Helen e de Cole.

A terceira temporada (2016-2017), ao contrário das demais, tem uma linha temporal presente maior que a passada, essa praticamente inexistente para Alison e Cole. A linha do tempo do passado dá prosseguimento à linha do tempo presente da temporada 2, correspondendo ao período em que Noah passou na prisão e ao início do relacionamento oficializado de Helen e Vik, o que inclui as visitas de Helen à prisão. Durante esse tempo, sabemos que Alison foi para uma clínica de reabilitação, após ter medo de perder Joanie para uma gripe forte e decidir deixá-la com Cole e Luisa (No final da segunda temporada, descobrimos que Cole, e não Noah, é pai de Joanie). O tempo presente corresponde à saída de Noah da prisão e sua tentativa de se reintegrar dando aulas em uma faculdade e seu envolvimento com a professora visitante francesa Juliette; à Helen e seu relacionamento com Vik, que fica abalado com a saída de Noah da prisão, principalmente por conta da culpa que Helen sente, por Noah ter sido preso em seu lugar enquanto ela que estava dirigindo; à Alison tentando recuperar a guarda compartilhada de Joanie, após tê-la deixado; e à Cole que tenta manter firme o seu casamento e ser um homem correto, apesar de ter dificuldades em esquecer Alison. O tempo passado tem maior impacto nos flashbacks de Noah na prisão, que irrompem com frequência seu tempo presente e estão relacionados a um policial que Noah acredita que o está 
perseguindo fora da prisão e que tentou matá-lo. O tempo presente se encerra em Paris, onde Noah vai para encontrar a professora Juliette e esbarra, por acaso, com sua filha Whitney e o namorado, um artista bem mais velho que ela. O namorado vai fazer uma exposição em Paris e Noah percebe que ele flerta com outras assistentes e que não lhe trata bem. Noah resolve voltar com Whitney para passar o Natal no Estados Unidos, a deixa com a família e a convence sobre repensar o relacionamento. Noah tem nessa temporada uma grande dificuldade em tentar se reaproximar dos filhos e também em lidar com a morte de sua mãe, que ocorreu durante sua adolescência, pela qual descobrimos que ele se sente culpado. Ela esteve muito tempo de cama e lhe pediu ajuda para tirar sua própria vida. Na terceira temporada, além da visão dos quatro protagonistas, temos também a visão de Luisa e Juliette.

A quarta temporada (2018) tem duas linhas temporais com um intervalo entre elas de seis semanas, um intervalo de tempo bem menor que os anteriores. A temporada se inicia com Cole e Noah, estranhamente juntos na estrada tentando saber o que aconteceu com Alison. Esse pequeno trecho corresponde ao tempo presente, que inicia os primeiros cinco episódios, seguido por sequências de cenas de tempo passado bem maiores, divididas em partes, como de costume. A linha de tempo passada conta a ida de Helen, Vik e os dois filhos mais novos para a Califórnia. Noah também vai para lá, a fim de ficar perto dos filhos e começa a trabalhar em uma escola. Enquanto isso, Cole continua tentando manter seu casamento com Luisa, apesar de seus sentimentos por Alison. Alison trabalha atendendo mães que perderam seus filhos, segue com a guarda compartilhada da filha e se envolve em um relacionamento com Ben, um ex. combatente. The Affair é uma narrativa complexa, envolvendo um grande número de personagens e, progressivamente, mais visões, assim tentar resumir os dramas de todos os personagens gerou um resumo extremamente grande e confuso, por isso decidi descrever a partir daqui apenas os movimentos narrativos relacionados à trama de Alison, que nos conduzem ao momento clímax dessa temporada que é sua morte. Alison começa a temporada muito bem, mas uma série de descobertas começam a desestabilizá-la, tais como finalmente conhecer o pai, que se revela não ser uma boa pessoa e descobrir que está se relacionando com um homem casado, de novo. Em uma tentativa de encontrar seu eixo, Alison viaja para encontrar Noah na Califórnia, 
mas, no avião, tem um problema com um homem que tenta agarrá-la, mas ninguém acredita. Noah questiona seu relato, o que foi a gota d'água para uma crise de pânico, resolvida por Vik, marido de Helen. O destino acaba fazendo com que Alison passe a noite na casa de Helen o que lhe permite ter uma conversa com potencial transformador, a qual será explicitada mais adiante. No episódio seguinte, as tramas de Noah e Cole se cruzam, chegando ao momento em que tempo passado e tempo presente se tornam um só: o momento em que ambos estão no carro de Cole procurando por Alison. No decorrer desse episódio, descobrimos que o corpo de Alison foi encontrado. Sabemos de antemão que Alison está morta, mas não o que aconteceu. O episódio nove apresenta o ocorrido de uma maneira surpreendente, o que também veremos adiante. E assim se concluiu a trama de Alison.

\subsection{Alucinações}

Antes de entrar no assunto da morte de Alison, vamos abordar outro fator que interfere na trama de The Affair, de maneira relevante, a partir da terceira temporada: as alucinações.

Uma alucinação é a percepção de que algo que não existe é real. Esse é um passo a mais na visão subjetiva da série, que já incluía a memória, a ilusão biográfica e os sentimentos.

Pela estrutura narrativa consolidada por The Affair, não é, em geral, possível avaliar o quanto próximo de uma realidade, tida como mais objetiva, estaria um relato. Durante as duas primeiras temporadas, já existem momentos em que as narrativas de um mesmo eventos são muito díspares, em especial, em momentos de forte emoção. Os sentimentos sempre moldaram os relatos. No entanto, na temporada 3, há uma série de momentos em que se percebe que há de fato uma distorção da realidade.

O exemplo maior disso é a trama de Noah. O que o público vê é a realidade de Noah, porém nem o público nem o próprio personagem sabem que ela está moldada por alucinações. A princípio, acreditamos que ele está sendo perseguido fora da prisão, pelo policial John Gunther, que esteve muito presente em sua vida carcerária, apresentada em seus flashbacks. O protagonista quase morre no primeiro 
episódio, por conta de uma facada no pescoço que acredita ter sido inferida por Gunther.

Posteriormente, somos levados a ter dúvidas sobre isso, havendo um momento em que o próprio personagem se dá conta de que nem tudo o que ele pensa ver é real. O ponto de virada para que Noah entenda que está tendo alucinações se dá quando ele vai atrás do policial fora da prisão e percebe que lhe faltam as marcas corporais de seus últimos confrontos no tempo presente. Isso confirma que o policial diz a verdade quando argumenta que não o vê desde a prisão e nega a realidade que Noah pensava ter vivenciado. Depois disso, tanto o que ocorreu no tempo presente, quanto os flashbacks, passam a ser vistos numa dimensão de insanidade e não mais apenas como passíveis de terem sido distorcidos por uma questão de percepção. Nessa temporada, muitas vezes temos seu plano ponto de vista com momentos de imagem turva ou distorcida.

Podemos justificar essas alterações de percepção pelo trauma dele por ter estado na prisão e, principalmente, pelo seu uso exagerado de relaxantes musculares.

Noah se lembra de um momento em que, na prisão, Gunther quis ler o texto que ele estava escrevendo: autobiografia de Jack Hunter. Ele seleciona passagens em que o protagonista do texto diz ter matado a mãe. Noah começa a surtar, dizendo que não escreveu nada daquilo e o acusa de ter escrito. O policial diz se sentir lisonjeado, mas considera tão absurdas as acusações que ignora e segue com suas perguntas. Noah defende o personagem (ele mesmo) por ter matado a mãe por ser o que ela queria. Gunther chama atenção para o curioso de concordarem sobre a situação - que ele matou a mãe -, mas discordarem sobre o significado do ato, pois enquanto Noah o considerava misericórdia, o policial o considerava um assassinato. Na sequência da cena, vemos Noah raivoso partindo para cima do policial, que desaparece daquele local como em um passe de mágica e reaparece em outro, fazendo com que Noah bata na parede.

A cena ressignifica a relação que havia sido apresentada entre Noah e Gunther. Passamos a considerar que a maior parte do que o policial fez com ele foi apenas fruto de sua imaginação, tanto no presente, quanto no passado. Não temos como saber se entre tudo o que havia sido narrado até então, algum evento teria sido 
real. Até então, a ambiguidade que a série apresentava se dava no embate entre os relatos, mas, nesse caso, a ambiguidade se apresenta em sua própria perspectiva.

\subsection{O impacto do psicológico na perspectiva}

Podemos dizer que mais do que a ação da memória, nas temporadas 3 e 4, o principal componente que altera os enquadramentos narrativos é o psicológico, que reflete os sentimentos e senso de realidade dos personagens.

Na temporada 4, nos episódios 8 e 9, vemos respectivamente as visões de Alison e Helen sobre uma conversa que tiveram em um bar. As cenas estão descritas por completo nos anexos para quem tiver interesse em comparar os diálogos. No entanto, convém destacar que se perde muita informação lendo apenas o texto, já que a narrativa também tem um componente imagético muito forte.

Figura 5 - As visões de Alison e de Helen
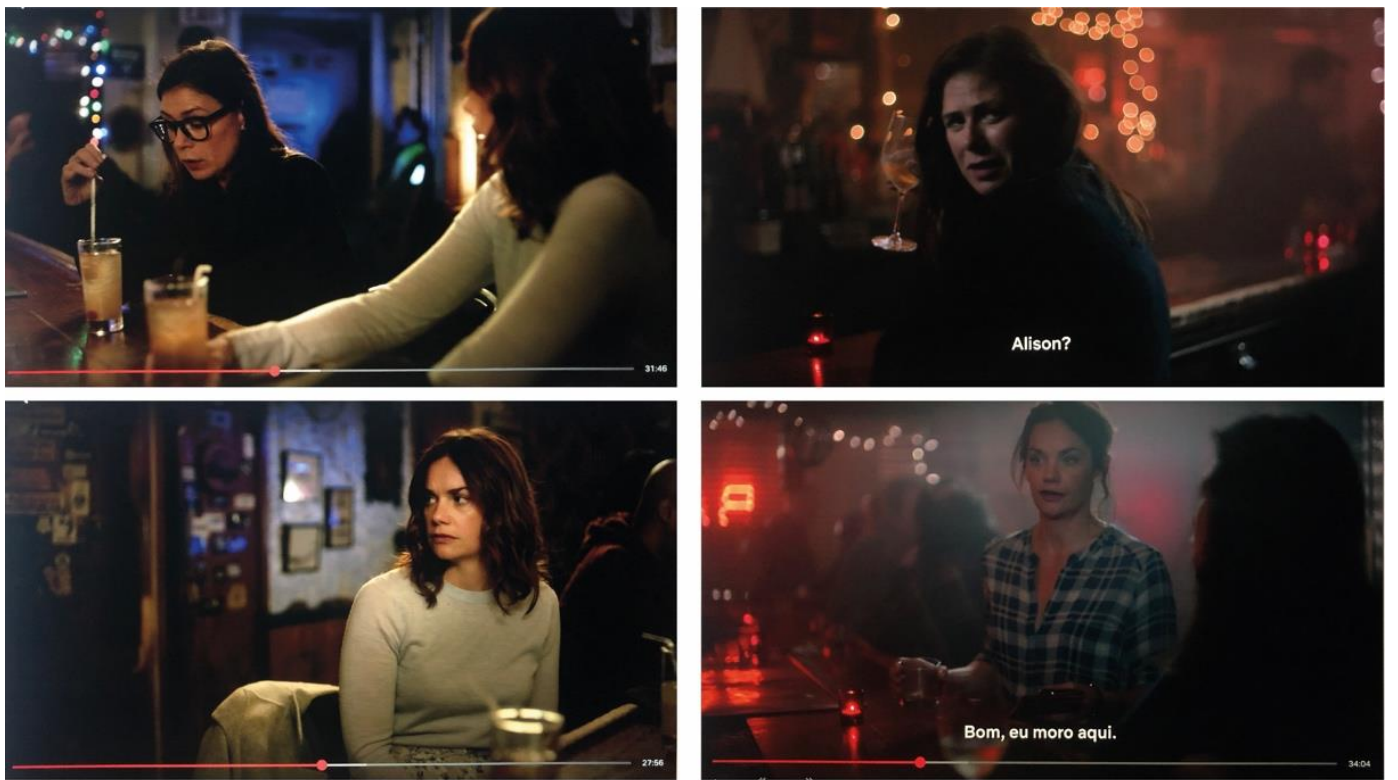

Perspectiva de Alison

Perspectiva de Helen

Olhando para a figura 5, à primeira vista, já é possível notar um elemento que marca a diferença entre as cenas: a cor. Enquanto a cena na visão de Alison é azul e se apresenta mais tranquila, com elas tendo momentos em que chegam a rir com cumplicidade, na visão de Helen a cena é vermelha, mais pesada, envolve acusações e a necessidade de agir. 
A roupa de Helen é semelhante nas duas visões, enquanto a de Alison é muito distinta. Ambas veem a outra como mais confiante que elas próprias se veem. É curioso que é sempre a protagonista de seu relato que está sentada, então a outra chega e, no final, sai de cena.

Além de comentar sobre os estranhos eventos que se passam com Noah, em comum, elas falam sobre o acidente de Scott, mas, segundo Alison, Helen diz para não desenvolverem o tema, e, segundo Helen, elas comentam o ocorrido e Helen quer convencer Alison, sem sucesso, a ir até a casa da mãe de Scott para que confessem tudo o que aconteceu.

Na visão de Alison, ela pede desculpas por ter tido um caso com Noah e Helen segura de si, diz que a culpa não foi dela. Na visão de Helen, esta acusa Alison de ter roubado seu marido e de não saber assumir culpas. Não é possível saber o que aconteceu, talvez parte desses diálogos representem o que elas gostariam de ter falado para a outra, mas não necessariamente o que falaram.

Entendendo o relato moldado por uma memória que é seletiva, há, nas visões de cada uma, momentos não relatados pela outra. A perspectiva de Alison inclui Helen the perguntando como ela via Noah. Faz todo sentido ela ter feito essa pergunta diante do fato de ela ter perguntado o mesmo para outros personagens, na sua visão, em episódios próximos. Isso deve ter chamado a atenção de Alison, principalmente por perceber que cada uma o via de uma maneira distinta. Helen lhe diz que acha que as pessoas veem nos outros o quer querem ver.

Na perspectiva de Helen, Alison fala muito sobre crianças, pergunta sobre seus filhos e fala de Joanie e Gabriel. O que também faz sentido pelo que conhecemos de Alison e deve ter sido um comportamento que chamou a atenção de Helen.

São típicas ambiguidades que fazem parte das cenas de The Affair, que nos levam a pensar no que essas dissonâncias simbolicamente podem significar, mais do que no que cada personagem diz especificamente.

The Affair é um convite para que a audiência mantenha uma flexibilidade em sua interpretação e estimule suas competências críticas. A ambiguidade faz parte do jogo narrativo da série. É preciso aceitar o paradoxo como parte desse jogo. 


\subsection{Xeque mate: o paradoxo como parte do jogo}

Chegamos ao clímax da quarta temporada: a morte de Alison, no episódio 9. O "que" acontece deixa de ser o foco da questão, pois já sabemos disso de antemão, o que importa nesse capítulo é o "como" acontece.

Aqui jaz a grande surpresa da série. O público de costume espera ver a visão de Alison. O episódio começa com a cartela que confirma que estamos vendo a sua visão. Quando sua visão acaba, aparece uma nova cartela também demarcando sua visão, mas revelando uma história completamente distinta.

Em ambas as versões, Ben, o homem com quem ela estava saindo, até descobrir ser casado, vai até sua casa. Na primeira, apesar dele lhe dizer que vai deixar a esposa por ela, ela se posiciona que não quer isso, mas, ao longo da conversa, acabam ficando juntos e a cena termina com Alison pensando em algo que faz seu rosto mudar de figura. Entendemos que ela deve estar pensando em suicídio. Na segunda versão, Ben chega à sua casa em um estado de espírito completamente diferente ao que vimos na cena anterior. Após Alison se impor de que não quer ficar com ele e o ameaçar de contar à sua mulher, ele a imprensa contra a parede, quebra seu pescoço e arrasta seu corpo para o mar.

Essa última versão possui uma narração de Alison em voice-over, em que ela diz que esteve sofrendo toda a sua vida e que, possivelmente, foi por isso que as pessoas a achavam fraca e a tratavam como tratavam. Contraditoriamente ao fato de seu corpo estar sendo jogado ao mar, ela diz que está cansada disso e que quer viver uma vida diferente, ter uma história diferente.

Será que a morte lhe permitiria renascer de outra forma? Com outra história? A série parece deixar essa possibilidade em suspenso, mas concretiza que, nessa vida, ela não terá mais a oportunidade de se reinventar, seguindo os conselhos de Helen: de deixar de ser vítima em sua própria história.

Na noite em que Alison passou na casa de Helen, se queixou da forma como os homens a viam. Helen lhe diz que, no caso de Ben, ela não sabia que ele era casado, mas de Noah, sim, que ela teve escolha. Aponta que reclamar que coisas ruins sempre lhe acontecem, não muda nada, o que muda é pensar diferente. Diz que ela precisa deixar de ser uma vítima em sua própria história e ter mais agência, se impor, não aceitando certas situações, e deixando claro para homens como Ben 
que não podem tratá-la assim. Helen chega a lhe dizer que o pior que poderia lhe acontecer era que o cara a xingasse. Coisa pior aconteceu, mas não temos como saber qual foi a participação de Ben nessa história.

Ambas as versões são plausíveis. Alison até havia, dias antes, transferido seu dinheiro para uma conta no nome da filha. A princípio, poderíamos considerar que são apresentados dois níveis narrativos onde nenhuma versão teria mais peso que a outra. No entanto, Bordwell optaria pela segunda versão.

Bordwell, ao comentar sobre o filme Corra Lola Corra, considera que o último fragmento sempre tem um status privilegiado de real: as partes de uma história não são iguais e a última apresentada ou completada é a menos hipotética. (BORDWELL apud WILLEMSEN, 2018)

Essa é uma possível chave de leitura, mas não é conclusiva. $\mathrm{O}$ fato de como a morte se deu ser mantido em suspenso, faz com que pessoas continuem tentando resolver essa ambiguidade, a fim de construir um sentido sobre o que aconteceu.

Quando o final se mantém ambíguo, deixa espaço para o público decidir o que ocorreu. Willemsen acredita que a imersão narrativa nas condições certas e o prolongamento da dissonância podem se tornar uma fonte de fascinação e não de frustração. Considera que a cognição dissonante pode ser um gatilho para que a audiência continue investindo energia mental na redução de suas incongruências, em vão ou não, fazendo com que o público teste seus diferentes enquadramentos e diferentes soluções interpretativas a partir das possibilidades deixadas pela narrativa. A insolubilidade pode prolongar seus efeitos por um longo período de tempo, mesmo após a experiência de assistir. (WILLEMSEN, 2018)

O fim de Alison pode ser relacionado de maneira metalinguística com uma cena do primeiro episódio da segunda temporada, onde Noah vai falar com seu editor. Ele precisa entregar a versão final do livro que escreveu com base nos habitantes de Montauk, que contém o caso extraconjugal do protagonista com Lana, que todos acreditam representar Alison. O editor quer convencê-lo de manter o final original, que era atropelar Lana na estrada, acreditando ser mais forte; enquanto Noah quer convencê-lo de que é menos clichê terminar com uma conversa entre os dois em um jantar do que apelar para uma morte trágica. $\mathrm{O}$ editor considera que a 
morte pode ser um fim não clichê quando é surpreendente, mas inevitável em retrospecto.

A morte de Alison se enquadraria nesse quesito. Em toda a série, a morte sempre esteve presente em sua vida, desde a perda de seu filho Gabriel. A morte se tornou um elemento de sua própria identidade. Como vimos, quando na primeira temporada, Alison pergunta para Noah o que ele vê nela, ela imagina que ele responda "morte" e diz ao investigador que não sabia se viveria até os 35 .

A água também sempre foi um símbolo presente não só na abertura da série: a série começa com Noah na piscina; tem várias cenas diante do mar, incluindo quando se reencontraram, quando o caso se inicia, e ela se cortando em um movimento de autopenitencia; a marca do mar em seus tramas, a morte de Gabriel e seu afogamento quando criança, que se repete em seus pesadelos; as viagens de barco, incluindo seu passeio com Ben, em que ela se arrisca até a mergulhar; e ela termina com o corpo no mar.

Surpreendente, mas inevitável em retrospecto. Um fim que em seu teor e sua forma mantém o que foi construído ao longo da série. A forma tem sua ambiguidade mantida.

Ainda que a estrutura da série faça com que o público acabe por naturalizar a ambiguidade por conta do eterno embate entre as diferentes apresentações da história, sua manutenção no fim de uma de suas protagonistas desperta no público o desejo de resolvê-la. Os fãs acordam de um momento em que já veem a ambiguidade como uma opção estética e sem necessidade de problematização a cada episódio, para outro distinto: em que têm dificuldade de conter seu estímulo natural de construir sentido. The Affair encerra a temporada convidando o público a refletir e atuar criativamente. 


\section{Thirteen Reasons Why - Construção e desconstrução narrativa}

\subsection{Sobre a série: sucesso e polêmicas}

Antes de começar a analisar a série, precisamos contextualizar seu lançamento e as polêmicas que o sucederam para, após abordada essa questão, podermos nos centrar estritamente em sua narrativa.

Thirteen Reasons Why (13rw) foi lançada, na Netflix, no dia 31 de março de 2017, rapidamente se tornando um fenômeno de audiência, tanto nos Estados Unidos, quanto no mundo. O canal de streaming disponibilizou, como de costume, todos os 13 episódios da primeira temporada de uma vez.

A série é uma adaptação do showrunner Brian Yorkey, do homônimo romance de Jay Asher. Diana Son é também showrunner da série e Selena Gomez assina sua produção executiva. Foi produzida por July Moon Productions, Kicked to the Curb Productions, Anonymous Content e Paramount Television.

Até o momento de escrita dessa tese, foram disponibilizadas 3 temporadas e já está previsto que a quarta, e última temporada, encerre a saga em 2020. A segunda temporada foi lançada em 18 de maio de 2018 e a terceira, em 23 de agosto de 2019.

Após seu lançamento, em 2017, a série foi a mais comentada do twitter: só no primeiro mês movimentou mais de 11 milhões de tweets. (COOK, 2017) Entre eles, muitos preocupados com a gravidade dos temas abordados na série, tais como violência, drogas, violência sexual, bullying e o grande tabu, o suicídio: evento que inclusive orienta toda a narrativa da primeira temporada, pois cada episódio corresponde a um dos porquês que levaram a personagem Hannah Baker a tirar sua própria vida.

A série ficou famosa pelas controvérsias geradas a respeito da abordagem e principalmente pelo choque das imagens gráficas relacionados ao suicídio. Pais, psicólogos, psiquiatras e educadores ficaram preocupados com a possibilidade da ficção estimular o suicídio dos jovens, como uma nova onda do chamado efeito Werther. Esse efeito considera a possibilidade do aumento no número de suicídios quando atos dessa espécie são tornados públicos pela mídia. O nome se refere ao protagonista do livro de Goethe, The sorrows of the Young Werther, que, assim 
como Hannah, decide se matar. Após a publicação do livro, em 1774, a taxa de suicídios sofreu um aumento e, por isso, muitos concluíram que o suicídio ficcional também poderia estimular o real, ainda que esta relação nunca tenha sido comprovada de maneira conclusiva. No entanto, o livro acabou sendo banido de vários locais. (SCHAFFER, 2018) Contudo me pergunto, como seria possível separar a influência da série Thrirteen Reasons Why no aumento de casos de suicídios, da influência da própria mídia, que ao falar extensivamente sobre o assunto também poderia ser capaz de incentivá-lo? Para responder a essa pergunta, seria necessário um estudo bastante aprofundado sobre o tema, com grupo de controle, identificando quem teve acesso a qual informação e, tanto os estudos acadêmicos que serviram como referência das matérias sobre a série publicadas por canais populares, quanto os estudos encontrados no google academics se mostraram pouco conclusivos.

Existem críticas positivas e negativas à série, estudos que a relacionam com o aumento de casos de suicídios entre jovens, com as crescentes buscas no google por palavras relacionadas ao tema, mas também com o aumento da taxa de procura por ajuda anti-suicídio. A maior parte das matérias encontradas pelo buscador do google relacionando o nome da série à palavra suicídio citavam as mesmas pesquisas, que não apresentavam métodos cientificamente comprovados ou careciam de imparcialidade (uma das pesquisas foi encomendada pela Netflix e, apesar de ter seu mérito, não pode ser considerada isenta).

Convém esclarecer que investigar sobre a relação entre a série e casos de suicídio foge ao escopo dessa tese. Contudo, devido a importância da controvérsia suscitada, não poderia simplesmente ignorá-la, assim fiz apenas um breve levantamento sobre essa questão na mídia ${ }^{26}$ e em artigos acadêmicos.

\footnotetext{
${ }^{26}$ Dados retirados da mídia digital de grande circulação ou especializada em séries que abordaram as controvérsias: http://www.adorocinema.com/noticias/series/noticia-140649/, https://www.bbc.com/portuguese/geral-48112247, https://observatoriodeseries.bol.uol.com.br/artigos/2019/08/13-reasons-why-tem-culpa-entendaporque-os-problemas-da-serie-sao-maiores-que-as-estatisticas, https://epoca.globo.com/saude/check-up/noticia/2017/07/serie-13-reasons-why-estimulou-ideiasde-suicidio-diz-estudo.html, https://oglobo.globo.com/cultura/revista-da-tv/13-reasons-why-viraalvo-de-polemica-levanta-questao-como-ficcao-deve-abordar-suicidio-21189561, https://veja.abril.com.br/saude/13-reasons-why-estimula-discussao-sobre-suicidio-com-jovens-dizestudo/
} 
Segundo pesquisa citada pela mídia, do Nationwide Children 's Hospital, as taxas de suicídio entre jovens de 10 a 17 anos nos EUA aumentaram 28,9\% ao mês após a estreia do programa. Vale ressaltar que essa taxa é em relação ao número de suicídios entre jovens do sexo masculino, pois não houve aumento significativo de suicídios no público feminino (público majoritário da série - 65\%) e que o mês anterior também teve índices maiores que os esperados, o que os investigadores justificam forçadamente como sendo efeito da publicidade prévia da série. Por outro lado, foi citado também um estudo da Universidade da Pensilvânia, que concluiu que estudantes que assistiram a toda a segunda temporada estavam menos propensos a cometer suicídio, e mais propensos a ajudar pessoas que pudessem apresentar qualquer tipo de problema, do que os que pararam no meio. Mas qual seria então o efeito da série para os estudantes que a abandonaram? Fica a dúvida.

O estudo encomendado pela Netflix, foi realizado pela Universidade de Northwestern $^{27}$, nos Estados Unidos, abrangendo seu território nacional, Reino Unido, Brasil, Austrália e Nova Zelândia. Ele revelou que $74 \%$ dos espectadores adolescentes pesquisados relataram que pessoas de sua faixa etária lidam com questões similares às apresentadas na série. Cerca de $90 \%$ dos entrevistados afirmaram que a série os ajudou a entender como suas ações podem impactar na vida de outras pessoas. A surpresa da pesquisa foi o fato de $60 \%$ deles declararem ter se desculpado com alguém a quem haviam tratado mal.

A mídia aborda os dois lados da moeda, mas cita estudos incapazes de sustentar o que apontam. Na busca por outras pesquisas acadêmicas, fiz um breve levantamento bibliográfico sobre o assunto, percebendo que a maior parte dos estudos encontrados a partir da busca do verbete "13 reasons why" no google academics atentam para os perigos da interpretação simplista dos dados sem a realização de pesquisas mais aprofundadas e para a inexistência de dados suficientes para afirmar que a ficção poderia causar ou influenciar suicídios entre os adolescentes. Muito pesquisadores em seus estudos, que eles próprios consideram ainda inconclusivos, encontram evidências de efeitos tanto negativos, quanto positivos. Entre os positivos estão que alguns jovens entrevistados disseram

\footnotetext{
${ }^{27}$ https://13reasonsresearch.soc.northwestern.edu
} 
ter sido incentivados a conversar sobre temas que antes não conversavam após ver a série e que esta os ajudou a perceber o impacto de suas ações sobre os outros. ${ }^{28}$

Há um estudo que chega a concluir que, entre os 80 jovens pesquisados, não houve nenhuma relação entre a série e comportamentos de risco suicida, destacando que quem teve qualquer aprendizado em relação à questão do suicídio eram pessoas que nunca haviam tido essa pretensão. ${ }^{29}$

Apesar de poder ser questionável a exibição da emblemática cena do suicídio, não houve um descumprimento de nenhuma lei por parte da Netflix. A Organização Mundial de Saúde tem diretrizes de censura para esse tipo de cena, mas esta só vale para redes sociais. (SCHAFFER, 2018)

Segundo os roteiristas, o suicídio foi mostrado com muito sofrimento, com o intuito de sublinhar o peso e a dor do ato e não para ensinar como se matar. Essa visão gerou opiniões contraditórias, mas foi tanta a pressão social que, em julho de 2019, mais de dois anos após o lançamento da série, a Netflix retirou a cena do ar.

No segundo mês de exibição, a Netflix já havia adicionado, em todos os episódios, notas de alerta que antes estavam só nos três primeiros. Nas temporadas seguintes, foram incluídos também mais avisos antes da exibição dos episódios, com os atores se apresentando e alertando sobre o conteúdo pesado da série, desaconselhando aqueles que estivessem passando por situações difíceis a assistirem ou sugerindo que vissem na companhia de um adulto de sua confiança. Convém destacar que no final do alerta aparecem os telefones dos centros de ajuda (no Brasil, o 141 do CVV - Centro de Valorização da Vida) e o site da série (13reasonswhy.info) que apresenta mais informações para quem precisar de auxílio ou conhecer alguém que precise. Segundo Schaffer, o impacto desse tipo de advertência nunca foi estudado, mas há autores que defendem que avisos de violência podem estimular, ao contrário, o desejo de ver o programa. (SCHAFFER, 2018)

\footnotetext{
${ }^{28}$ https://ps.psychiatryonline.org/doi/full/10.1176/appi.ps.201800384 https://www.sciencedirect.com/science/article/abs/pii/S0277953619302072 https://www.sciencedirect.com/science/article/abs/pii/S0890856719302886 https://jamanetwork.com/journals/jamapsychiatry/article-abstract/2734859 https://onlinelibrary.wiley.com/doi/abs/10.1111/sltb.12517

${ }^{29} \mathrm{https} / / / \mathrm{www}$. tandfonline.com/doi/full/10.1080/07448481.2019.1586713?src=recsys
} 
A série também teve críticas positivas e muitos fãs consideraram que ela os ajudou a falar sobre o tema. O número de pessoas que procuraram ajuda no CVV aumentou $445 \%$ e tiveram $170 \%$ mais acessos ao site em $2017^{30}$.

As polêmicas continuaram nas outras temporadas. A segunda temporada contou com outra cena gráfica chocante. O estupro do personagem Tyler: levado por um grupo de atletas para o banheiro da escola, onde colocaram sua cara dentro da privada e outro personagem, Montgomery, o estuprou com o cabo de uma vassoura. A cena seguinte mostra Tyler sangrando e olhando para seu arsenal de armas. Muitos consideraram a violência da cena desnecessária, mas Bryan Yorkey a defendeu dizendo que eles tinham o objetivo de mostrar situações que muitos adolescentes passam e que isso inclui experiências extremamente angustiantes e difíceis de digerir. A temporada quase terminou com uma chacina escolar, impedida por um personagem. Clay se colocou na frente de Tyler que estava com uma metralhadora e conversou com ele, argumentando que Hannah se matou e que isso nada mudou: que se ele fizesse isso, seria só mais uma história que faria as pessoas sofrerem por uma semana, antes que todos seguissem em frente. Muitas pessoas consideraram que essa foi uma solução absurda para evitar uma chacina.

Na terceira temporada, a polêmica ficou a cargo do tratamento mais humano dado ao vilão. Seria certo mostrar também o lado bom de um estuprador? Nesse ponto, apesar das críticas, inclusive de fãs, seguiu um movimento já iniciado na segunda temporada de tentar desconstruir os relatos e mostrar os outros lados da história. Polêmicas à parte, a série talvez possa ser redimida por seus críticos ao mostrar que, apesar de aparentemente estar evoluindo, o personagem ainda conservava comportamentos violentos e egoístas, que provocaram sua morte. A temporada se encerrou com um novo dilema: deve-se deixar alguém já morto levar a culpa por um crime que não cometeu, protegendo assim alguém que está vivo e matou, mas sem a intenção de fazê-lo?

Podemos apenas concluir que as séries podem influenciar tanto positivamente quanto negativamente e às vezes uma mesma narrativa pode causar efeitos diversos em diferentes pessoas. Trabalhar com ficção é sempre uma responsabilidade. Tratar sobre o tema do suicídio vai sempre levantar polêmicas.

\footnotetext{
${ }^{30} \mathrm{https}$ ///revistagalileu.globo.com/Revista/noticia/2017/07/precisamos-falar-sobre-o-suicidio.html
} 
No entanto é uma discussão relevante por este ser um problema crescente, sobretudo entre os jovens. Exige, contudo, uma abordagem muito cuidadosa, sob o risco de despertar um efeito de contágio.

Dito tudo isso e polêmicas à parte, esse capítulo tem como objetivo entender os mecanismos de construção e desconstrução com os quais a série opera.

\subsection{Como tudo começou}

Ao som de uma música melancólica, o plano revela um armário de escola. Ele está cheio de flores, bilhetes e cartões colados, além da foto de uma garota sorrindo, com nome Hannah colado em letras coloridas abaixo. Ouve-se a voz de Hannah enquanto o plano vai se tornando cada vez mais aberto.

Oi! Aqui é a Hannah! Hannah Baker! Você está certo. Não ajuste seu... o que quer que esteja usando para ouvir isso. Sou eu, ao vivo e em estéreo. Sem promessa de retorno, sem bis, e, desta vez, com certeza sem atender a pedidos. Pegue um lanche. Acomode-se. Porque vou contar a história da minha vida.

O plano aberto revela Clay, seu melhor amigo e amor não correspondido, fechando a porta de seu próprio armário. Silhuetas semi desfocadas de estudantes cruzam o quadro, passando pela frente do armário. Vemos o plano do olhar de Clay, em seguida seu plano ponto de vista, no qual vemos Hannah. As silhuetas ao passarem por sua frente fazem-na desaparecer, como uma ilusão que some em um passo de mágica. Vemos novamente o plano do olhar de Clay desiludido. Ele se aproxima do armário de Hannah, diante do qual duas meninas estão batendo uma selfie. Comentam o quanto ela era bonita e uma pergunta à outra qual hashtag usar: \#neverforget.

Assim começa a ser contada a história de uma garota que resolveu tirar sua própria vida, narrada por ninguém menos do que ela mesma. Em cada um dos lados das sete fitas cassetes, serão revelados os treze motivos que a fizeram tomar essa decisão irreversível. Cada episódio constitui uns desses treze motivos, direcionado a um personagem em especial.

Fitas cassetes? Sim! E esta não é uma série de época. Hannah escolheu esse suporte por considerar que ouvir tudo o que ela passou, tinha que demandar esforço. Precisava que fosse algo mais difícil do que receber um arquivo digital por e-mail. 
Envolvia em primeiro lugar conseguir um aparelho que pudesse lê-las. O áudio gravado em uma fita acaba por se apresentar de uma maneira física, o que nos leva a pensar que esta seria uma forma de Hannah materializar seus depoimentos. E mais, cada um que recebesse uma caixa com as sete fitas, deveria ouvir todas e, depois, passá-las adiante para o próximo da lista. As fitas então também não ficariam com a pessoa para sempre, a menos que fossem copiadas. Assim, a oportunidade de ouvi-las estaria circunscrita a um certo período de tempo. Junto às fitas havia um mapa que marcava os locais onde suas histórias se passaram, então quem quisesse poderia ouvir os depoimentos em seus respectivos cenários.

Sobre o processo de desenvolvimento desse capítulo da tese, primeiro serão apresentados os personagens, introduzindo os porquês de Hannah; em seguida veremos os arcos narrativos principais de cada temporada; posteriormente analisaremos os mecanismos narrativos utilizados, incluindo os textuais e os imagéticos.

Comecei a assistir as duas primeiras temporadas sem o intuito de investigálas academicamente. No entanto, a forma com que a trama foi sendo conduzida na segunda temporada, revelando novos olhares por cima do que foi sedimentado na primeira temporada e relativizando esses discursos, despertou meu interesse, já que eu estava estudando narrativas multiperspectivas. Vi a terceira temporada com isso em mente, contudo só comecei a desenvolver esse capítulo alguns meses depois, o que me obrigou a rever a maior parte dos episódios e a refrescar minha memória com resumos na internet. Assisti novamente metade de todas as temporadas e revi os demais episódios em modo acelerado, parando em certas passagens para analisálos com mais atenção. Enquanto revia a série, fui desenvolvendo a análise, tendo em vista sua narrativa e os mecanismos visuais adotados. Ao longo desse capítulo, recorri a imagens da própria série para ilustrar visualmente a tese. Tive que tirar fotos da tela, uma vez que existe algum tipo de bloqueio na Netflix para realizar o printscreen. Assim, posteriormente, tive que cortar as fotos em um editor de imagem. Por conta de algumas distorções naturais da foto, o enquadramento original pode variar alguns pixels do encontrado aqui e a imagem pode apresentar algum reflexo.

Um dos grandes desafios do capítulo foi apresentar os inúmeros acontecimentos de modo resumido, escolhendo entre eles quais eram os mais 
relevantes para a narrativa da série. Thirteen Reasons Why é uma narrativa complexa, que entrelaça a cada temporada pelo menos duas linhas temporais e conta com um gigantesco número de personagens, sendo inúmeros protagonistas. São muitas relações, que exigem dos fãs memória e esforços interpretativos e cognitivos. Sua trama é construída, desconstruída e reconstruída através das temporadas, estabelecendo um jogo constante entre compreensão e confusão. Algumas tramas se estendem pelas temporadas e muitos dramas, devido à sua gravidade, permanecem no tempo.

A série inclui inúmeras peças soltas e contradições para serem reveladas, constituindo mistérios que aguçam a atenção dos fãs. Veremos no item arcos narrativos os principais mistérios que cada temporada reserva.

Convém destacar que o grande número de personagens presentes na trama gera muitas possibilidades de identificação, tanto em relação às suas identidades, quanto aos dramas vivenciados.

\subsection{Apresentação dos personagens}

Foi uma tarefa difícil destacar apenas 15 personagens para apresentar aqui. Concentrei-me nos porquês de Hannah e aproveitei para apresentar os pais dos personagens junto ao item dos filhos. Apesar dos pais serem relevantes na trama, eles são sempre apresentados como sendo de alguma forma mais ingênuos que os jovens, pois estes é que sabem o que de fato está acontecendo, ou ao menos têm algumas pistas sobre isso.

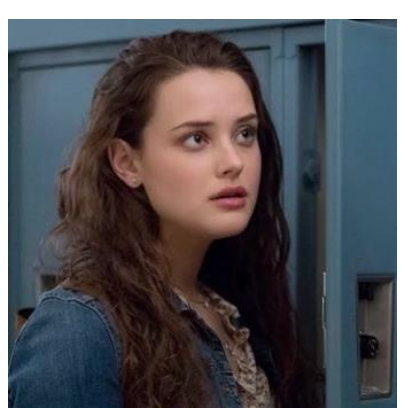

Hannah Baker: Tendo em conta que o tempo presente da trama se desenvolve após a morte da Hannah, as imagens que vemos dela sempre representam uma linha temporal passada. Ou fazem parte da imaginação de Clay, seu amigo que também sentia por ela um amor não correspondido. Na primeira temporada, a gravação de Hannah conduz a linha de tempo presente, mais precisamente, a narrativa avança ao passo que Clay a escuta. As imagens de Hannah em flashbacks ilustram seu depoimento e as lembranças dos personagens. Hannah chega à cidade com uma boa 
dose de autoconfiança e com um senso de humor afiado, mas sua personalidade acaba sendo impactada pela relação com os personagens citados na fita, tornandose uma menina triste e incapaz de ver futuro em sua vida. Hannah vivia com seus pais, Olivia e Andrew Baker. Com a perda de Hannah, Olivia tem dificuldade em pensar em qualquer coisa que não seja entender os motivos da filha e encontrar culpados. O pai apoia a esposa em alguns momentos, mas em outros acredita que ela deve esquecer o passado e seguir adiante. Ele havia começado um caso extraconjugal, sobre o qual Hannah descobriu e exigiu que confessasse à mãe, o que ele não fez. Apesar de não ter lhe endereçado uma fita, esse motivo também contribuiu para sua decisão. Os pais só têm acesso às fitas no final da primeira temporada. Na segunda, já separados, a mãe de Hannah dá seguimento em tribunal a sua ação judicial contra a escola, responsabilizando-a pela morte da filha.

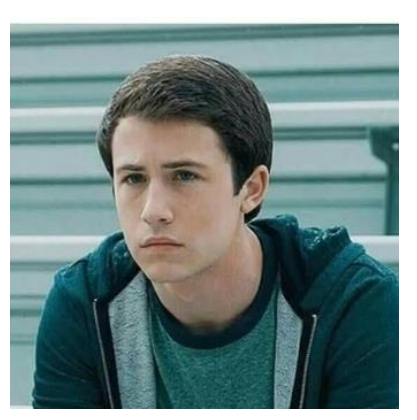

Clay Jensen: Clay vai descobrindo, ao longo da primeira temporada, as razões que levaram Hannah a tirar sua própria vida. Ouvir a voz da Hannah nas fitas o deixava muito mal e como uma válvula de escape, numa tentativa de fazer justiça à amiga, ele resolve se vingar de algumas pessoas. O que mais lhe angustiava era entender o que ele havia feito para se tornar um dos treze motivos. Essa angústia fez com que beirasse a loucura algumas vezes. Em alguns momentos, ele transita em uma linha tênue entre acreditar em sua fala e a desconfiança dela estar mentindo. Ao longo das fitas, ele começa e descobrir que alguns fatos não eram verdade e, sendo assim, não sabe identificar o que é e o que não é. Em algumas das gravações, mesmo ouvindo o que Hannah dizia, ele não entendia muito bem o motivo dela ter ficado chateada. $\mathrm{Na}$ segunda temporada, ainda descobre que houve fatos que Hanna omitiu, trazendo a ele dúvidas a respeito de se realmente a conhecia. Clay é extremamente leal aos amigos. Ao longo das temporadas, passa de um nerd inseguro, meio sem amigos ou traquejo social, para um garoto que é um elo de união entre o grupo que se forma a partir das fitas de Hannah. Todos o consideram uma boa pessoa e que vale a pena superar a impressão inicial meio esnobe que ele passa. Mora com seus pais, que são bastante preocupados com ele. A mãe é advogada e sua empresa é chamada para defender a escola na segunda temporada. Nas últimas fitas, Clay descobre que, 
afinal, não fazia parte da lista dos trezes porquês: Hannah apenas o tinha incluído na lista dos destinatários porque queria que soubesse de sua história.

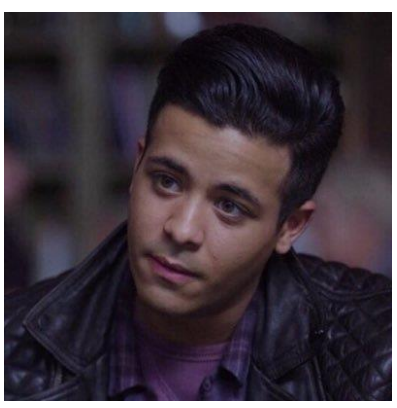

Tony Padilha: Tony era o encarregado por garantir que todas as treze pessoas recebessem as fitas e as passassem adiante e, caso alguém não o fizesse, todas as fitas se tornariam públicas. Tony é dos melhores amigos de Clay. Ele trabalha na oficina mecânica da família, composta por imigrantes latino americanos. É o mais novo de seus irmãos homens. É forte e faz justiça com as próprias mãos quando julga necessário, motivo que lhe rendeu duas passagens pela polícia. Conjuga um estereótipo de machão com sua homossexualidade. Apesar de não fazer parte da lista, se considerava de certo modo também culpado pela morte de Hannah, pois não atendeu a porta, quando ela a tocou. Quando, enfim, abriu a porta, encontrou lá as fitas e uma mensagem contando sobre o plano. Ainda tentou correr até sua casa para tentar impedi-la, mas já era tarde demais.

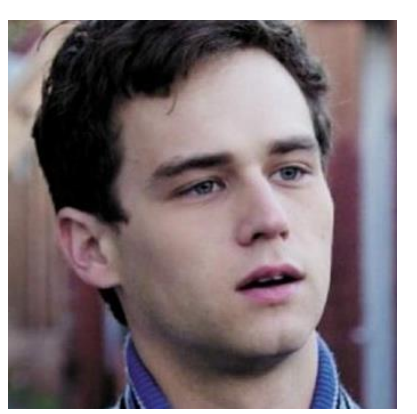

Justin Foley: Justin é um garoto de família pobre, cuja mãe é viciada em drogas e namora um traficante. Ele próprio tem problemas com drogas. Apesar de seus erros, e de uma relação de dependência com os garotos do futebol, é possível perceber que ele tem um bom coração. Sua ligação é mais forte com Zach e com Bryce, que acabou o apadrinhando, de certo modo, desde a infância. $\mathrm{O}$ amigo rico dividia suas coisas com ele, mas também em troca exercia um certo controle. Justin foi o primeiro beijo de Hannah e o que se seguiu a isso foi o marco que ela considerou como o início de tudo: ele tirou uma foto dela descendo no escorrega, onde é possível ver sua calcinha. A foto parou nas mãos de Bryce, que a espalhou. Um boato viralizou pela escola, de que havia acontecido algo mais que um beijo entre eles, o que Justin não desmentiu, deixando Hannah bem chateada. No entanto, na segunda temporada, a partir dos testemunhos de Tyler e Ryan em tribunal, vamos descobrir que ela continuou falando com Justin depois disso, inclusive trocando 
fotos sensuais com ele. Mas a culpa de Justin não termina por aí, a fita 5, lado A, também o responsabiliza por Bryce ter estuprado Jéssica semi desacordada. Jessica era sua namorada naquele momento e ele tentou, mas não conseguiu, impedir o melhor amigo. Hannah também se culpa pelo mesmo motivo, pois estava no armário e viu tudo, mas, paralisada, também não fez nada. A segunda temporada trás para Justin novos laços fraternais e a possibilidade de se redimir.

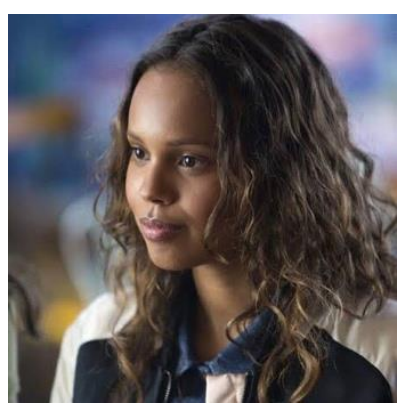

Jessica Davis: Jessica foi das primeiras amigas de Hannah no colégio. Foram apresentadas pela antiga conselheira que considerou que, por serem alunas novas, poderiam ajudar uma a outra no colégio. O que poderia ter sido um plano frustrado, acabou gerando uma amizade, devido a identificação que sentiram por ambas possuírem um senso de humor ácido. Começam a tomar chocolate quente juntas no café Monets. Um dia elas percebem a presença de um garoto curiosamente interessante e vão até sua mesa. É Alex, e elas o convidam para fazer parte do grupo que desabafa no café sobre os pesares de suas vidas escolares. Hannah e Jessica brigam aparentemente por motivos pequenos, mas com consequências drásticas. Jessica não vai acreditar, a princípio, nos depoimentos de Hannah sobre o estupro e o restante. Depois passará a fazer todo o possível para sobreviver ao ocorrido e irá se fortalecer ao longo da segunda e terceira temporadas. Seu coração irá transitar entre Alex e Justin, mas apesar de tender mais para o segundo, será difícil perdoálo por tudo o que aconteceu.

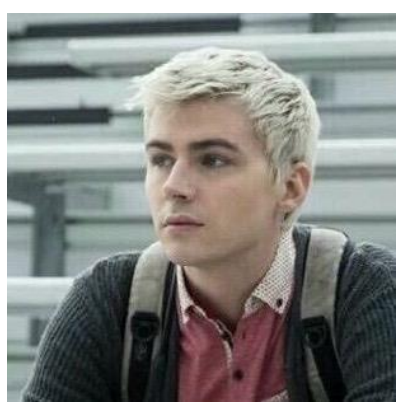

Alex Standall: Alex teve como primeiras amigas em seu novo colégio Hannah e Jessica. A amizade começa a ruir quando Alex faz novos amigos, os atletas, e tem fim quando ele se envolve romanticamente com Jessica. Hannah se sente deixada de lado e ele corrobora com o fim do trio, convencendo Jessica de que devem se afastar de Hannah até que ela supere seus ciúmes dos dois. Em suas fitas, Hannah o relaciona à teoria do caos, ao efeito borboleta. Após ter ficado com raiva de Jessica 
por não querer ter relações mais íntimas com ele e romper com ela, Alex, em um gesto infantil, coloca em uma lista de papel, com atributos das garotas da escola, os nomes de Hannah na categoria "melhor bunda" e de Jessica na de pior. Jessica, sem entender o motivo do rompimento, acaba acusando Hannah de ter feito algo para isso e o pior, esse gesto de Alex desperta o interesse de Bryce por Hannah. Alex ouve as fitas repetidas vezes e fica muito perturbado, o que acabará causando sua tentativa de suicídio mal sucedida. O pai de Alex é policial e tem arma em casa.

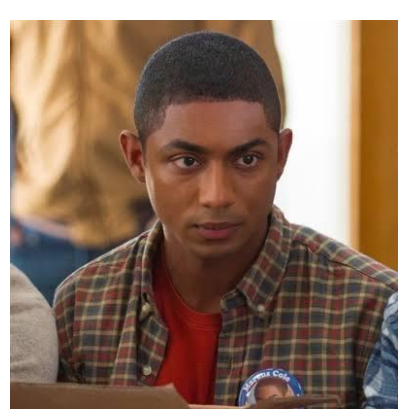

Marcus Cole: Marcus tem fortes aspirações políticas, seguindo os passos de seu pai. No colégio, se candidata à presidência estudantil e se elege. É amigo dos atletas, principalmente por conta do interesse que nutre por suas popularidades. É citado por Hannah por conta de uma ação organizada pela escola chamada de Dollar Valentine, que se propunha a juntar casais com base em respostas preenchidas em um formulário. Um computador relacionava os dados e Hannah saiu em sua lista de pretendentes. Ele percebe o interesse de Zach em tirá-la, e aposta com os atletas se gabando do que poderia fazer com ela. Ele a convida para sair e chega mais de uma hora atrasado à lanchonete, levando consigo Zach e outros atletas, que se sentam em outra mesa. Após Hannah ter desculpado seu atraso, ele se senta ao seu lado e tenta passar a mão em suas pernas de maneira agressiva. Ela o empurra para se defender. Revoltado, Marcus a chama de maluca, desmente ter feito o que fez e vai embora. Zach sai atrás de Marcus com os outros meninos, mas retorna e se senta com Hannah, que praticamente o ignora. Marcus continua falando mal de Hannah nos corredores da escola, mas ela o vê fazendo isso e o encurrala.

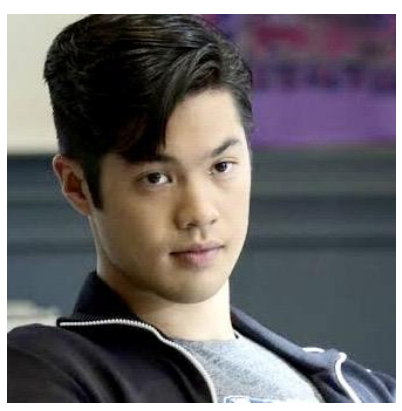

Zach Dempsey: Zach faz parte do grupo de atletas, mas algumas atitudes o destacam, como o fato de não entrar na maior parte dos bullyings. Mas, ainda assim, comete atos sobre os quais nada se orgulha, em geral por conta de sua covardia. No fundo sabe reconhecer o certo do errado e, quando a situação se complica, não permite que outras 
pessoas paguem pelos erros que considera seus. Ao longo das temporadas, se aproxima mais de outros personagens, principalmente de Alex, e se afasta de Bryce, apesar de manter uma proximidade física com ele por conta do time, acreditando que o esporte que vai lhe garantir um lugar na universidade. É um pouco fechado, comportamento que mais tarde atribui à sua mãe. Desde pequeno, aprendeu como imigrante sobre a necessidade de ser forte e superar dramas. Após o que Marcus faz a Hannah, ele se aproxima dela e tenta animá-la sem sucesso, pois ela estava devastada. No dia seguinte, na cantina da escola, pergunta como ela está e diz que gostaria de ter saído com ela e confessa seu interesse. Hannah, com o mesmo padrão defensivo que muitas vezes apresenta com Clay, não acredita e grita com ele na frente de todos, rendendo-lhe um grande constrangimento. Depois, Hannah manda uma carta para Zach, acusando-o de roubar os seus bilhetes de elogios, atividade proposta em uma aula, e dizendo o quanto ela se sentia sozinha na escola. $\mathrm{Na}$ gravação, ela diz que viu que ele pegou sua carta e a jogou no chão. Após Clay ter riscado o carro de Zach, como forma de retaliação ao que Hannah disse ter visto, Zach alega que ela mentiu ou achou ter visto ele fazer algo que não fez; estende, então, a Clay a carta de Hannah, que ele carregava consigo. Na segunda temporada, porém, vemos que a maior parte da história dos dois não havia sido contada por Hannah e nem por ele próprio. Falaremos mais adiante sobre isso.

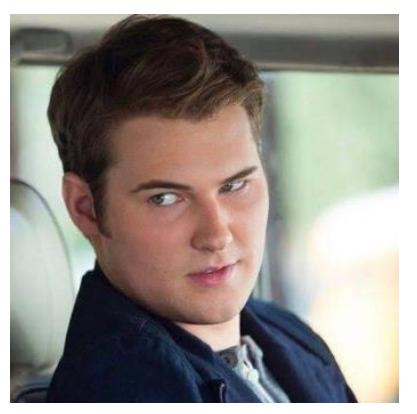

Bryce Walker: Bryce poderia ser considerado como o grande vilão da série. É capitão do time da escola, os Tigers, e desfila pelos corredores com um rei com seus súditos atletas. É responsável pelo estupro de Jessica e de Hannah, motivo revelado na penúltima fita como o maior responsável pelo suicídio de Hannah. É por isso que Hannah se refere a Alex como o desencadeador do efeito borboleta, pois a leve batida de sua asa, indicando-a como a "melhor bunda", causou um furacão em outro lugar. Bryce, primeiramente, apertou a bunda de Hannah em uma loja de conveniência, após lhe comprar o que ela queria e, dias depois, a estuprou. Bryce é extremamente mimado e acredita que o dinheiro compra tudo. Não aceita nãos como resposta e tem pouca clareza sobre a violência às mulheres que provoca com seus atos. A terceira temporada da série tenta humanizá-lo como alguém que, após 
ter passado por algumas dificuldades como um rompimento de um namoro e a entrada em um novo colégio, começa a tentar reavaliar seus atos.

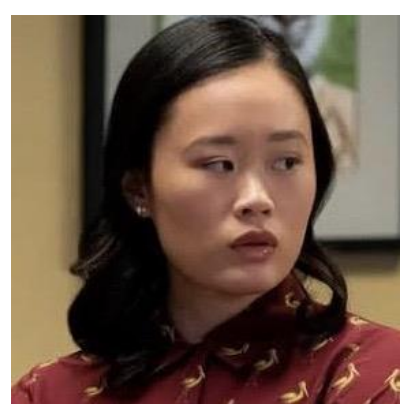

Courtney Crimsen: Courtney faz parte, junto a Marcus, da diretoria estudantil. Conhecida por todos como uma pessoa agradável, ela acabou sendo uma das grandes decepções de Hannah, pois, para tentar esconder sua homossexualidade, prejudicou Hannah, espalhando boatos sobre sua vida. Tudo começou quando ela se ofereceu para ajudar Hannah com um stalker ${ }^{31}$. Esta lhe contou que alguém, que imaginava ser uma pessoa estranha de sua rua, a tinha fotografado pela janela no dia anterior. Elas resolvem pregar uma peça na pessoa, esperando o momento que se aproximasse para jogar uma luz de lanterna ofuscante em sua face, descobrindo sua identidade. Elas bebem e trocam confidências, resolvem fazer um jogo de verdade ou consequência e esquecem da missão. Durante uma consequência, elas se beijam e Hannah percebe o que este beijo representava para Courtney e se esforça para que seja especial. Porém, nesse momento se ouve o ruído de uma câmera. Hannah, prontamente, interrompe o beijo e pega a lanterna. Surpreende Tyler a fotografá-las. Courtney, ao perceber que se tratava de alguém da escola, sai correndo da casa de Hannah desesperada. Tendo crescido com pais gays, tinha grande receio que eles se sentissem culpados. Ninguém na escola as reconheceu na foto, mas Courtney disse a Monty que era Hannah com outra garota.

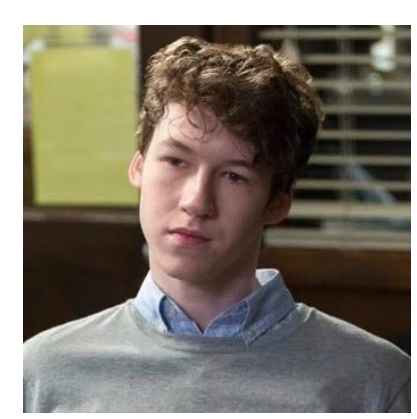

Tyler Down: É o fotógrafo da escola. Ele se escondia atrás da câmera e sofria muito bullying. Tirou fotos de Hannah logo que ela entrou para o colégio e tentou ser gentil com ela e lhe dar força quando a foto de Justin viralizou, mas ela o interpretou mal. Tyler também tinha uma paixão não correspondida por Hannah. Quis lhe entregar suas fotos impressas para tentar animá-la, mas a encontrou com Clay. Envergonhado, se escondeu e acabou presenciando Hannah trocando fotos ousadas

\footnotetext{
${ }^{31}$ Stalker é um perseguidor que segue alguém, fisicamente ou virtualmente.
} 
pelo telefone. Tirou fotos e no dia seguinte ao vê-la com uma garota em sua janela, se escondeu novamente e começou a fotografá-las, segundo ele para entender o que estava acontecendo, e deixou vazar uma dessas fotos, motivo pelo qual se tornou um dos 13 porquês. Clay, revoltado, tirou uma foto de Tyler entrando pelado no quarto, pela janela, e compartilhou na escola. No final da segunda temporada, Monty e outros atletas o estupram com uma vassoura, fazendo com que se revolte e vá armado para o baile da escola, pronto para praticar uma chacina, mas é impedido por Clay.

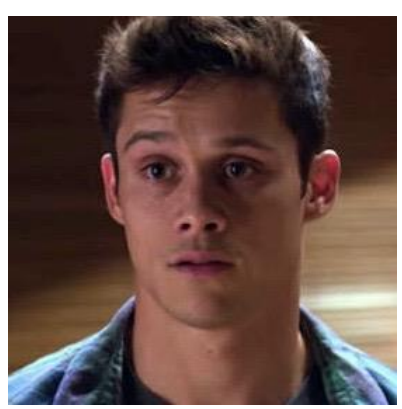

Montgomery de la Cruz: Monty é atleta e amigo de Bryce. É uma das pessoas que mais pratica bullying no colégio, sendo cruel com muitos, especialmente com Tyler. Contribui para espalhar os boatos sobre Hannah, mas por não ter lhe feito nada diretamente não está em suas fitas. Na terceira temporada, apenas, é que conhecemos mais sobre a sua personalidade e vida. Ele apanha constantemente do pai e se enfurece ao ceder à sua própria homossexualidade mal resolvida. Acabou morto na prisão, após ser condenado pelo que fez com Tyler.

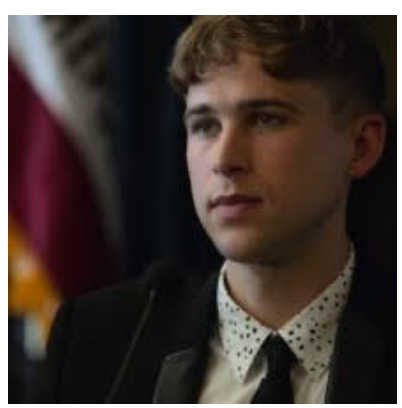

Ryan Shaver: Ryan, ao contrário dos últimos personagens citados, vive totalmente à vontade com sua homossexualidade, assumida desde a infância. Inteligente e editor do jornal da escola, acabou conhecendo melhor Hannah pelo interesse que mantinham pela poesia. Ele tenta ajudá-la a escrever melhor, dizendo que ela é uma artista e que precisa apenas não ter medo de se revelar. A incentiva a fazer uso de seu diário, assim tem acesso a algumas de suas poesias, que descobre terem a ver com Justin. Por realmente considerar que o trabalho dela era bom e querer tê-lo em seu jornal ou para provar a ela seu valor como artista, conforme alega, publica anonimamente seu poema no jornal da escola. A publicação sem sua permissão faz com que ela o torne um dos treze porquês. 


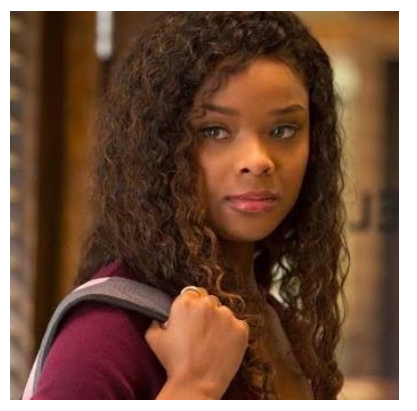

Sheri Holland: Sheri abandonou Hannah na estrada, depois de baterem o carro em uma placa e a derrubarem. Sheri teve medo de contar aos pais e perder a carteira de motorista. Hannah queria avisar sobre a placa, mas estava sem bateria no celular e quando conseguiu chegar em um posto caminhando, já era tarde demais: por falta da placa, ocorreu um acidente, em que um aluno faleceu. Na segunda temporada, Sheri tenta se redimir, ajudando Clay a desintoxicar Justin e a descobrir sobre as misteriosas polaroids

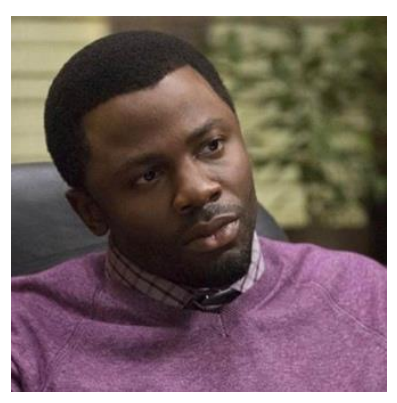

Kevin Porter: Conselheiro da escola que negligenciou o caso de Hannah quando ela o procurou. As fitas despertam seu senso de proteção aos alunos. Na segunda temporada, faz até justiça com as próprias mãos, chegando a intimidar Bryce, no banheiro da escola, para que fique longe de Jessica. Na terceira temporada, ele desperta a desconfiança de Clay e de seus amigos, por estranhamente estar ajudando Bryce, mas seu objetivo era apenas que ele melhorasse como pessoa.

Outra personagem importante é Ani, mas deixarei para apresentá-la quando abordarmos a terceira temporada, já que ela está a parte da trama nas duas primeiras temporadas.

\subsection{Arcos narrativos}

Com seu grande número de personagens, a série oferece numerosas perspectivas para se compreender sua narrativa. As verdades são confirmadas, desenvolvidas ou contraditas pela continuidade da série.

\section{Primeira temporada}

A primeira temporada inicia um arco de descobertas, a partir do personagem Clay, a respeito dos motivos que fizeram com que Hannah se matasse. Acompanhamos as angústias de Clay e toda a instabilidade que mentalmente e 
psicologicamente vai se apoderando dele. A cada episódio, há um motivo e um culpado. Ele interage com todos esses "culpados" e ainda com outros personagens.

A narrativa entrelaça o tempo presente de Clay com o tempo passado da história de Hannah, que por vezes o cita ou o faz lembrar também de momentos que viveram juntos. Ela se constrói majoritariamente a partir na narrativa em voice-over de Hannah, pois ela corresponde ao lado da fita que Clay está ouvindo no episódio. Uma vez que sua escuta faz a história avançar, ele é claramente o protagonista, junto com Hannah, que relata o que lhe aconteceu sobre o seu ponto de vista. A maior parte das outras pessoas citadas nas gravações já havia ouvido as fitas antes dele.

Figura 6 - Linhas temporais da primeira temporada

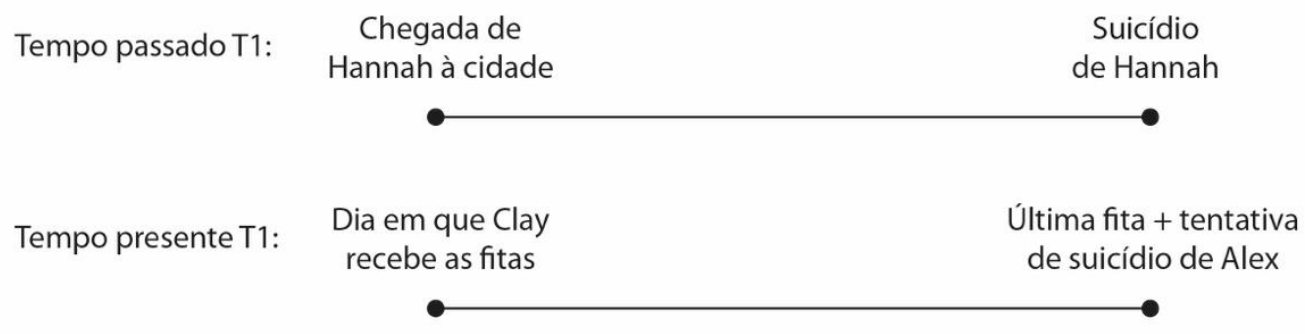

A imagem que se constrói na tela representa a vida presente de Clay, ou a narrativa de Hannah, ou lembranças de Clay e dos outros personagens, ou a vida presente dos outros personagens principais. Clay, portanto, não é onisciente, não está a par de tudo o que o público vê na tela. Diferentemente de The Affair, em que tudo o que aparece na tela tem a presença do protagonista. Os momentos em que Clay não está presente também podem apresentar a narrativa de Hannah.

O voice-over de Hannah sempre começa e termina os episódios, mas não está presente durante todo o episódio ininterruptamente. Clay usa o mapa deixado por Hannah junto com as fitas e, assim, vai com sua bicicleta até o local correspondente a onde a história relatada se passou. Nesse momento, o público ouve o áudio de Hannah e o tempo passado se entrelaça ao tempo presente.

Há muitos momentos em que vemos Clay com os fones escutando o áudio, mas não é preciso que ele esteja com os fones para que a narrativa seja apresentada: é como se ele tivesse acabado de ouvir e fosse até o local visualizar a cena. Essa semelhança espacial entre as duas temporalidades cria uma narrativa ligeira que 
realiza as trocas temporais, principalmente, fazendo o uso de planos ponto de vista e de planos detalhe. Veremos sobre isso adiante. Ao final da temporada, sabemos que um outro personagem atentou contra a própria vida, Alex. Temos também os arcos do conselheiro da escola, Kevin Porter, investigando sobre o que aconteceu e da mãe de Hannah, que busca justificativas e culpados para o ocorrido.

Essa é a relação entre os episódios, os personagens citados como porquês e alguns eventos de extrema relevância que ocorrem durante a primeira temporada:

Episódio 1: Fita 1, Lado A: Justin

Episódio 2: Fita 1, Lado B: Jéssica

Episódio 3: Fita 2, Lado A: Alex

Episódio 4: Fita 2, Lado B: Tyler

Episódio 5: Fita 3, Lado A: Courtney

Episódio 6: Fita 3, Lado B: Marcus

Episódio 7: Fita 4, Lado A: Zach

Episódio 8: Fita 4, Lado B: Ryan Shaver + Tony conta para Clay os detalhes da morte de Hannah

Episódio 9: Fita 5, Lado A: Justin (pelo estupro de Jessica por Bryce)

Episódio 10: Fita 5, Lado B: Sheri

Episódio 11: Fita 6, Lado A: Clay

Episódio 12: Fita 6, Lado B: Bryce + Clay grava uma confissão de Bryce + alguém dá um tiro na cabeça

Episódio 13: Fita 7, Lado A: Sr. Porter + Revelação que foi Alex que tentou cometer suicídio + Justin foge e conta para Bryce das fitas + Jessica conta para o pai sobre o estupro + Tyler esconde algumas armas + Clay fala com Skye (sua namorada no início da temporada 2) sobre as cicatrizes que ela tem em seu pulso.

\section{Segunda temporada}

A partir da segunda temporada, parte do grupo dos acusados por Hannah em suas fitas divide com Clay o protagonismo. A cada episódio, um personagem é convidado a depor em tribunal: ou escolhidos pela defesa, que representa a escola, ou pela acusação, que representa os pais de Hannah, mais precisamente sua mãe. Olívia quer responsabilizar a escola pela morte da filha. A segunda temporada 
começa cinco meses após a morte de Hannah e dá seguimento à história do ponto em que a primeira temporada parou.

Figura 7 - Linhas temporais da segunda temporada

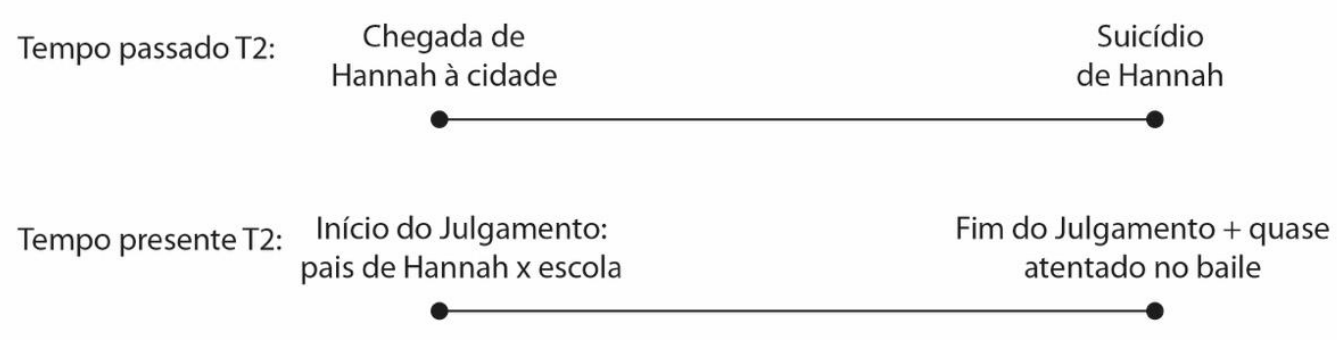

O tempo passado da primeira e da segunda temporada é o mesmo. As duas primeiras temporadas estão intimamente relacionadas: a segunda temporada reconstrói e ressignifica a narrativa da primeira. A narração presente no episódio corresponde ao depoimento do personagem, ou seja, cada episódio é narrado por um personagem diferente e o que vemos representado na tela é a sua lembrança, a qual não corresponde necessariamente ao seu testemunho, pois há desde os que revelam segredos que gostariam de guardar entre sete chaves até os que mentem em proveito próprio.

Ao mudar o referencial, o ponto de vista, a narrativa é reconstruída. Novos dados são acrescentados e verdades são relativizadas. Contudo, é preciso ter em mente que isso se dá de maneira inteiramente distinta à série analisada no capítulo anterior, The Affair, em que vemos a lembrança dos personagens com uma gama fortíssima de influência de sua subjetividade. Aqui a subjetividade se faz mais neutra, ainda que, em alguns momentos, a imagem chegue a nos mostrar o que personagem diz que viu ou acha que viu e, depois, se comprove a impossibilidade dessa visão. Como no caso de Zach, que é acusado de ter jogado no chão a carta de Hannah, mas vemos que ele a guarda em sua carteira.

O tempo passado nessa temporada é evocado, na maior parte das vezes, pelos testemunhos. Assim o personagem está no tribunal, enquanto a história entre ele e Hannah se passa em outro espaço. Essa dinâmica alterou bastante o ritmo da série. Embora o tribunal não demarque, a priori, uma situação de intimidade, os depoimentos acabam revelando histórias muito íntimas dos personagens. Essas 
histórias trazem novas camadas para a narrativa de Hannah, ora levantando dúvidas ou suspeitas, ora confirmando suposições e ora demonstrando suas diversas facetas: seus lados bons e ruins. Acima de tudo, geram questionamentos a respeito da identidade da jovem, o que perturba intensamente Clay e a mãe de Hannah, fazendo com que se perguntem, em muitos momentos, se, de fato, a conheciam. Essas revelações fazem de Hannah uma personagem mais complexa ainda, com muitas camadas que expressam inúmeras contradições inerentes aos seres humanos. Há também os que mentem no tribunal, o que contribui ainda mais para esse embaralhamento, mas estes mentem apenas para os demais personagens, pois o público vê a representação visual de suas memórias e acompanha grande parte dos personagens, tendo assim acesso a informações que outros personagens não têm. Convém destacar que a ordem em que as pessoas são chamadas a depor não corresponde à das fitas de Hannah.

A trama do tribunal corre em paralelo a outras tramas:

- Clay chega a tentar esquecer Hannah e engrenar em um relacionamento com Skye, mas as coisas acabam não correndo bem. Hannah aparece para ele como fruto de suas alucinações, inclusive começando a dialogar com ele e cobrando que faça algo para lhe fazer justiça. Sua namorada vai para uma clínica de reabilitação, por ter também tendências suicidas. Isso tudo faz com que ele considere que precisa realmente fazer algo por Hannah e conseguir que Bryce seja preso. Como Jessica se recusa a falar, Clay vai atrás de Justin para que ele possa testemunhar. Um agravante é o recebimento anônimo de polaroids com cenas de estupros e afins ligadas aos atletas, inclusive a Bryce.

- Justin, após a descoberta de Jessica na primeira temporada, de que ele não impediu seu estupro, foge roubando dinheiro do namorado traficante da mãe e acaba nas ruas. Vive como um sem-teto drogado até que Clay chega com Tony para resgatá-lo e o esconde em sua casa. Os pais de Clay acabam descobrindo e permitem que fique por lá, dada a sua situação familiar. Clay realiza um trabalho de desintoxicação de Justin, com a ajuda de Tony e Sheri. Justin só consegue pensar em obter o perdão de Jessica.

- Jessica tenta se recuperar da descoberta do estupro, pois quase até o fim da primeira temporada achava que Hannah havia mentido na fita. Ela se junta a um 
grupo de ajuda a mulheres. Volta a ser amiga de Alex e resolve lhe dar uma nova chance mais para o final da temporada, porém, no último episódio, seu amor por Justin bate mais forte e ela acaba ficando com ele.

- Alex fica com sequelas físicas e de memória por conta de sua tentativa de suicídio, que lhe atingiu a cabeça. Não consegue se lembrar de nada que aconteceu nos últimos tempos, incluindo o porquê de tentar se matar. Pede desesperadamente a Clay as fitas de Hannah, na esperança de que se as ouvisse, se lembraria de tudo. É ajudado em sua recuperação por Zach, de quem, ao mesmo tempo, desconfia por ainda andar com Bryce.

- Zach ajuda Alex e, apesar de não considerar mais Bryce como amigo, continua andando com ele por conta do time. Sua participação no tribunal revela um envolvimento entre ele e Hannah até então inimaginável.

- Bryce circula impune pelo campus. Assume um namoro com Chloe e, conforme seus atos vão sendo revelados pelo tribunal, tenta mascarar a situação para enganá-la.

- Tyler, após se decepcionar com os outros que foram convidados a depor e que não se expuseram tanto quanto ele, consegue se enturmar com Cyrus e seus amigos, que resolvem fazer justiça com as próprias mãos, pregando peças nos atletas e em Marcus. Ele foi vítima de muitos bullyings, motivo inclusive que fez com que a mãe de Hannah o escolhesse para depor em seu favor. Acaba sendo pego por um de seus atos e seus pais lhe mandam para uma instituição de ajuda. Ele volta muito bem, mas é pego por Montgomery e outros atletas que o levam para o banheiro e consumam a cena do já mencionado estupro. De volta à casa arrasado, ele começa a fazer fotos suas e pega todo o arsenal de armas que havia juntado ao longo das temporadas e leva para o baile. Sua raiva e indignação são contidas por Clay, que pede para que ele fuja com Tony e fica com as armas. 
Figura 8 - Fantasma de Hannah na vida de Clay
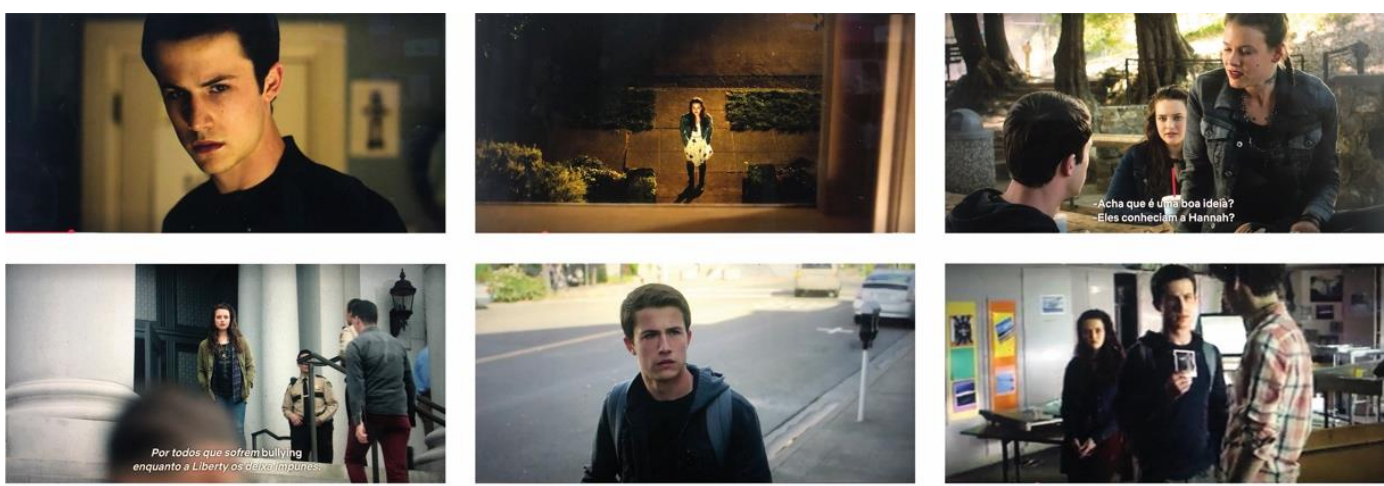

Nas duas primeiras colunas, temos o plano ponto de vista de Clay e seu plano do olhar, mostrando que Clay via Hannah em locais em que ela não estava. Na última coluna, duas cenas mostram Hannah como fantasma participando da cena de Clay, inclusive falando com ele.

Há outras histórias que poderíamos mencionar, mas acredito que estas sejam as mais relevantes para a temporada. Alguns personagens tentam seguir a vida em frente, como se ela pudesse voltar a ser normal após as fitas, mas isso não se mostra possível. Um novo mistério, as polaroids, forma uma trama a parte, a fim de se descobrir o que acorria entre alguns atletas e garotas em um local que chamavam de The Clubhouse.

A ordem dos episódios segue abaixo:

Episódio 1- A Primeira Foto Polaroid: Testemunho de Tyler

Episódio 2 - Duas Garotas Se Beijam: Testemunho de Courtney

Episódio 3 - Vagabunda e Bêbada: Testemunho de Jessica

Episódio 4 - A Segunda Polaroid: Testemunho de Marcus

Episódio 5 - A Máquina de Giz: Testemunho de Ryan Shaver

Episódio 6 - O Sorriso nas Docas: Testemunho de Zach

Episódio 7 - A Terceira Polaroid: Testemunho de Clay + Clay envia as fitas de Hannah anonimamente para a internet

Episódio 8 - A Garotinha: Testemunho de Andy e Olivia Baker + Marcus é chantageado por Tyler e Cyrus para entregar Bryce como estuprador, em seu discurso diante de toda a escola, a fim de não vazarem um vídeo seu com prostitutas. Episódio 9 - A Página Faltando: Testemunho de Pam Bradley (professora) e Kevin Porter 
Episódio 10 - Sorriam, Babacas: Testemunho de Sarah, que fala sobre Hannah fazendo bullying com ela em sua antiga escola + Testemunho de Tony Padilha + Sheri consegue ser convidada para a The Clubhouse e passa a senha para Clay e Justin + Zach confronta Bryce durante um jogo e diz que sabe que ele estuprou Hannah + Zach encontra Clay e Justin na The Clubhouse revelando ser ele quem lhes mandou as polaroids.

Episódio 11 - Bryce e Chloe: Testemunho de Bryce Walker Episódio 12 - A Caixa de Polaroids: Testemunho de Justin Foley

Episódio 13 - Adeus: (Como não há testemunho a narração é de Clay) Bryce recebe pena de apenas três meses, enquanto Justin de seis meses, por confessar ter se omitido durante o estupro, mas ambos conseguem liberdade condicional + Chloe conta para Jessica que está grávida de Bryce + Funeral de Hannah + Baile da escola em que Tyler chega armado e Clay o convence a não realizar uma chacina.

A série mescla os gêneros coming of age (no caso, adolescente), mistério, crime e drama. Todas as temporadas fazem uso de mistérios, mas é a terceira que aprofunda o gênero policial. É possível notar que até a cartela cromática se modifica de acordo com a atmosfera requerida. Os mistérios geram engajamento do público, que despende esforço para solucioná-los.

\section{Terceira temporada}

Nessa temporada, três eixos temporais são entrelaçados e se desdobram ao mesmo tempo.

Ani, garota recém-chegada à escola é quem conduz a trama, com sua narração em voice-over. Ela conta para um policial o que aconteceu a respeito de um assassinato. Essa não é uma situação de intimidade e, pior, é preciso tomar cuidado com o que diz para que isso nem se volte contra ela, nem prejudique alguém que ela

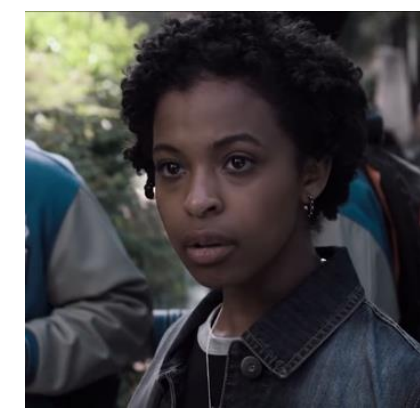
quer, na verdade, proteger. Ani é uma das personagens principais, mas não a única protagonista. O ponto de vista narrativo é múltiplo, a série segue diferentes personagens, dando a conhecer suas histórias individuais e perspectivas. 
Ani vive com sua mãe, que foi contratada como enfermeira para cuidar do avô de Bryce. Elas vão morar na nova casa em que Bryce vive com o avô e a mãe, agora separada do marido. A separação abala Bryce. Ani acaba se envolvendo com ele, primeiro como amiga e, depois, como bem mais que isso. Apesar de saber o que diziam a respeito dele, pensa que com ela poderia ser diferente. $\mathrm{O}$ que torna a trama ainda mais complicada é que ela faz amizade com Clay e com Jessica, que poderíamos chamar de inimigos declarados de Bryce, escondendo deles seu relacionamento. Mente também para Bryce, dizendo conhecer Clay apenas superficialmente. Ela está sempre com Clay e claramente reconhece o interesse que ele tem por ela.

A narrativa opera pelas costuras temporais, mas cada eixo temporal se desenvolve de maneira linear. O que foge à linearidade são apenas os eventos que correspondem a alguma revelação.

Figura 9 - Linhas temporais da primeira temporada

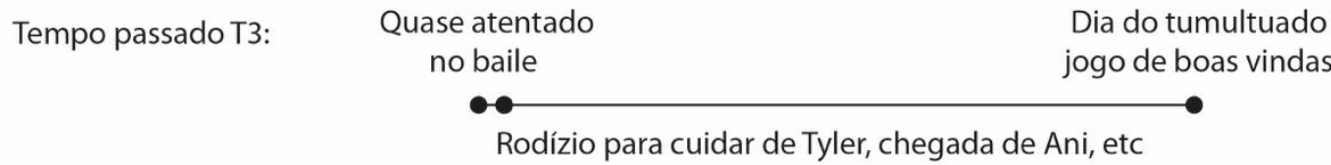

Depoimento de Ani

Tempo presente/futuro T3:

O tempo passado revela tudo o que aconteceu após o término da segunda temporada: desde o resgate de Tyler por Clay e Tony, incluindo o rodízio que criam entre os amigos para cuidar dele, e a chegada de Ani à cidade, até o jogo de boas vindas de futebol americano entre a Liberty High School e nova escola de Bryce. A linha que chamei de tempo presente vai do dia após o jogo, em que grande parte dos alunos da escola se metem em confusão brigando em campo, incluindo os que não estavam jogando, até o momento em que Ani vai depor. O momento em que Ani depõe chamei de tempo presente/futuro. Convém destacar que esses nomes foram arbitrários, servindo apenas para facilitar a apresentação da narrativa. No 
início da linha do chamado tempo presente, Bryce desaparece, e depois seu corpo é encontrado no mar.

É possível notar com facilidade que essas temporalidades estão demarcadas por uma diferenciação em sua cor e forma. A linha do tempo que corresponde a Ani depondo, que chamamos de tempo presente/futuro, apresenta a imagem em preto e branco. As imagens da linha do tempo presente possuem cores mais escuras, enquanto as do passado, cores mais saturadas ou mais quentes.

O formato de tela varia: no tempo passado é widescreen 16:9, 1.78 aspect ratio, mesmo formato da primeira temporada, e no tempo presente é mais estreito, 2.22 aspect ratio. ${ }^{32} \mathrm{Em}$ alguns momentos, o plano se altera diante dos nossos olhos, com a tela aumentando ou diminuindo, revelando a mudança do tempo da narrativa, sublinhada pela alteração da cor.

Figura 10 - Passagem de tempo passado para tempo presente na terceira temporada.
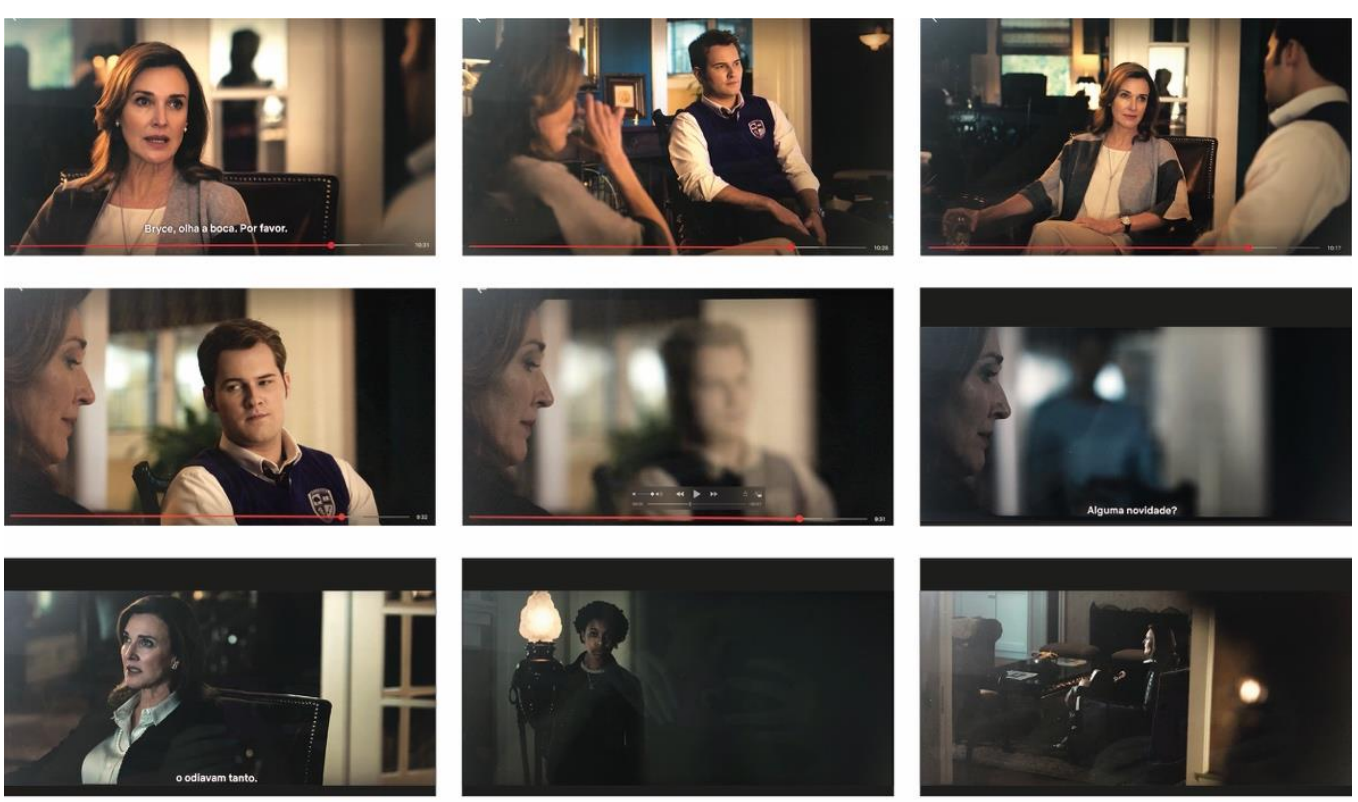

As imagens da primeira linha correspondem ao tempo passado, na segunda linha é possível ver a transição diante dos nossos olhos. Enquanto a mãe de Bryce, Norma, se mantém no plano, Bryce desaparece, dando lugar à sombra da mãe de

\footnotetext{
${ }^{32} \mathrm{O}$ valor de Aspect ratio (proporção de tela) representa quantas vezes um lado é maior que o outro. Especificações técnicas do tamanho de tela de Thirteen Reasons Why encontradas em: https://www.imdb.com/title/tt1837492/technical?ref_=ttloc_sa_5 https://www.refinery29.com/en-us/2019/08/241251/13-reasons-why-flashbacks-wide-screen-pastpresent-aspect-ratio
} 
Ani, que aparece no quadro. A terceira linha corresponde à linha do tempo presente. Nela percebemos que Ani observa a cena por seu plano do olhar (penúltima imagem) e seu plano ponto de vista (última imagem). Veremos mais detalhes sobre esses recursos utilizados para os entrelaçamentos temporais mais adiante.

Logo no início, Ani, a narradora, deixa claro que não é confiável, pois mente. Todos mentem. Até o nome do segundo episódio da temporada corrobora com essa afirmação: "Se você está respirando está mentindo".

Ao longo da narrativa, todos parecem culpados e começam a desconfiar uns dos outros. Ani, junto a Clay, se tornam praticamente os detetives na série, indo atrás de todos para fazer perguntas.

Apenas na terceira temporada é que Bryce, no carro com Tony, ouve todas as fitas de Hannah e parece ter mais consciência do mal que lhe causou. Tenta pedir desculpas à mãe de Hannah e grava suas desculpas a Jessica em uma fita cassete, um ato que simbolicamente encerra um ciclo começado pelas fitas de Hannah.

Uma frase de Justin diz muito sobre a premissa da temporada a respeito de Bryce. Após vê-lo chorar muito ao saber da morte de Bryce, Clay o questiona por suas lágrimas. Ele diz que Clay sabe o que sabe, mas que não sabe tudo sobre Bryce: que ele era uma pessoa, um ser humano. A temporada o descontrói como apenas um vilão. A própria mãe, Norma, chega a reconhecer o filho como um monstro, mas percebe que ele tem também outras facetas melhores. Elas não contradizem seus atos, mas complexificam seu carácter ao revelar também seu melhor lado.

No episódio 11, Ani diz ao policial em seu depoimento (tempo presente/futuro): "nesse ponto você deve achar que juntou as peças, pode achar que achou o culpado, mas você está errado." Ela diz que, vendo Clay passar pelo que passou, é muito fácil, ainda que fosse inocente, que parecesse culpado, pois ele não agia como inocente. A verdade é que todos têm segredos, a maioria deles sem relação com a morte de Bryce, mas o simples fato de terem algo a esconder, os torna suspeitos. Além disso, terem realmente algo contra Bryce só agrava a situação.

No episódio 12, Zach, por medo de que Clay pagasse por algo que achava que havia sido sua culpa, vai até o pai de Alex, decidido a fazer uma confissão. Em sua cena anterior, no treino dos Tigers, se despede do time e comenta sobre o que as pessoas diziam dele. Fala que não importa o que os outros dizem quando se sabe 
quem se é. Revela à polícia que surrou Bryce e o deixou desamparado para morrer nas docas. Os polícias o liberam, dizendo que ele no máximo o machucou, pois ele morreu com água nos pulmões, para a surpresa e alívio de Zach.

Ani revela ao pai de Alex tudo o que aconteceu, mas sugere, dada toda a situação e o fato da morte não ter sido intencional, que incriminem Monty, morto na cadeia após ter sido preso pelo que fez com Tyler.

O pai de Alex decide seguir o conselho de Ani. Contudo Monty tinha um álibi para a noite em que Bryce foi morto: ele estava dormindo com um estudante da escola nova de Bryce, o que não revelou para ninguém. Este estudante, após saber sobre a incriminação de Monty, procura Ani e Clay revoltado para dizer que isso não estava certo. Deixa-se um gancho de que a mentira poderá ser revelada na quarta e última temporada, causando toda uma reviravolta.

Nessa temporada, Tyler finalmente conta para Clay o que lhe aconteceu e, posteriormente, para Jessica, por meio de um vídeo. Ela lhe diz que ele não é mais a mesma pessoa do vídeo e ele concorda. Já havia dito a Clay que, por causa dele e da ajuda de todos, teve a chance de ser outra pessoa.

Jessica, como presidente dos alunos, posto que galgou decidida a trazer mudanças para a escola, faz um discurso, onde incentiva todos os alunos da escola sobreviventes de estupros a se apresentarem. Tyler se levanta diante de todos, muitas garotas e garotos fazem o mesmo, incluindo Justin.

A temporada termina com uma exposição de fotografia de Tyler, que agradece a todos aqueles que estiveram ao seu lado e acreditaram em sua superação.

\subsection{Revelados, ocultados e contraditos}

Sabemos claramente que Hannah omitiu fatos, no entanto não temos como afirmar se ela alguma vez mentiu ou se equivocou acreditando falar a verdade. Como vimos nos capítulos anteriores da tese, verdade ou mentira sempre tem a ver com a intenção que se tem.

Nos primeiros capítulos da primeira temporada da série, vemos a evolução de Clay, de um garoto meio assustado e traumatizado pela perda da amiga para um 
garoto ora justiceiro, acreditando nos relatos de Hannah, ora confuso e desconfiado de que certos fatos não fossem verdade.

Sua angústia se multiplica por ele não fazer ideia do que poderia ter feito para se tornar um dos porquês. Hannah não lhe avisa de antemão que ele não faz parte da lista de culpados por sua morte, revelando sua inocência apenas na Fita 6, Lado A, ou seja, no episódio 11 da primeira temporada. Isso faz com ele ouça muitas fitas, com situações se tornando cada vez mais graves, até descobrir que ela o inclui apenas para que soubesse de sua história.

Percebe-se pelo flashback de Clay que, enquanto Hannah apresenta outras fitas, quase sempre demorando para revelar a quem ela é endereçada, surgem lembranças de um momento em que se beijaram. Teme, com isso, ter lhe criado algum grande mal não intencional.

O público também pode ver, durante as lembranças de Clay, que ele com frequência era mal interpretado por Hannah e que a chateava sem querer. Ele chega a comentar em uma cena, passada no cinema em que trabalhavam, como uma conversa tão curta entre os dois podia acabar tão rápido e tão mal. Situação similar acontece com Zach quando vai checar se Hannah está bem, após o incidente com Marcus, e se declara para ela. Por esses eventos é possível perceber como os traumas que Hannah vai criando vão moldando seu entendimento da conversa com outros homens, sendo às vezes injusta com aqueles que realmente gostam dela. Clay se mantém apaixonado por ela e, em geral, abstrai seus foras, sabendo que no dia seguinte irão se falar novamente. Zach, do contrário, se sente extremamente ofendido, se tornando vingativo e lhe diz que algumas das coisas que ela reclama que acontecem com ela são sua própria culpa.

Tendo em conta que cada personagem carrega a sua realidade, maus entendidos ocorrem com frequência e sem diálogo são incapazes de serem solucionados. A morte de Hannah impede a continuidade de um diálogo, mas suas fitas deixam margem para que as suas manifestações continuem a ecoar em um tempo em que sua presença já não faz parte.

Uma das pessoas mais angustiadas pela morte de Hannah é sua mãe. A gravidade do fato em si junta-se ao sentimento de incompreensão de seus motivos. Diferentemente de outros protagonistas, ela não recebe as fitas, mas um grande 
silêncio, tornando as razões para a morte da filha um grande mistério. Ela se debruça nos vestígios deixados por Hannah na esperança de, a partir deles, reconstituir a sua história a fim de compreendê-la.

$\mathrm{Na}$ fita referente a Jessica, Hannah comenta: "Perder um grande amigo nunca é fácil. Principalmente se você não entende por que o perdeu". Na narrativa essa perda se refere a outra situação, mas é possível estabelecer um laço entre a frase e a situação de sua mãe. No momento em que Clay escuta essa fita está diante da casa de Hannah. Por seu plano ponto de vista na janela do quarto de Hannah é possível ver a amiga. A tela volta para seu plano do olhar e, depois, em seu novo plano ponto de vista vemos Olívia no quarto da filha. Ele vai embora correndo. A narrativa corta para dentro do quarto de Hannah, onde sua mãe pinta as unhas com o esmalte azul da filha e lembra-se dela. Em seguida, ela acha a lista da "melhor e pior bunda". Chama o marido para falar sobre o que viram no facebook de Hannah e afirma que a lista confirma que ela sofreu bullying. Ele considera insuficientes todas as provas que têm para mover um tribunal, ainda mais tendo em conta que a maioria das mensagens desagradáveis era anônima. Olívia afirma conhecer a filha, mas o pai a questiona sobre isso. Ela recorre a Tony para ajudá-la a entender o que aconteceu. Pede também ajuda a Clay para juntar as peças. Ela é uma personagem que sabe menos que Clay e menos que o público.

Figura 11 - Plano do olhar de Clay seguido por seus planos ponto de vista: Hannah e sua mãe na janela.
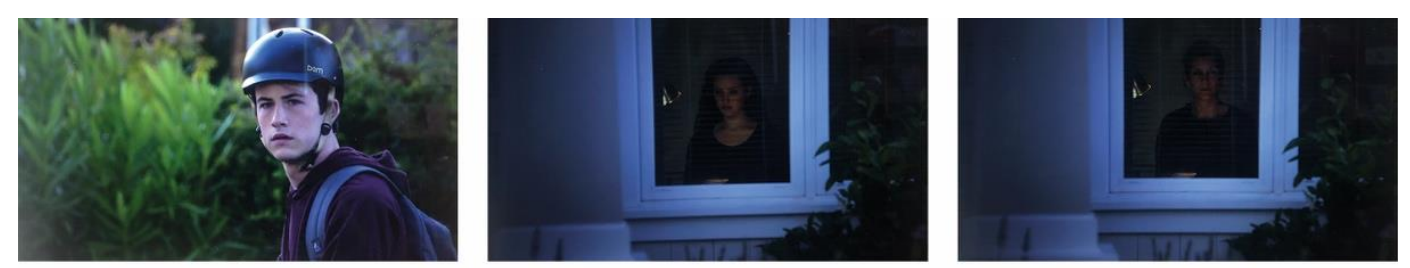

Na primeira fita, Hannah diz que já ouviu tantas histórias sobre ela que não sabe qual é a mais popular, mas sabe qual é a menos: a verdadeira. Comenta que a verdade nem sempre é a versão mais emocionante, melhor, ou pior das coisas, que é algo no meio, mas merece ser ouvida e lembrada. Afirma que a verdade sempre aparece e permanece.

Permanecer não parece um verbo que faz jus à primeira e à segunda temporada, em que os discursos estão sendo a todo tempo confrontados. Já na 
primeira, o que Hannah diz é muitas vezes posto em questão pelo que os outros personagens contra-argumentam. Alguns podem estar equivocados, outros têm provas do que dizem e outros podem simplesmente pensar diferente.

Quando Clay interpela Jessica sobre ser verdade o que Hannah disse nas fitas, ela a chama de mentirosa. Diz que não foi ela que parou de ir ao Monets, mas sim a própria Hannah, e acha que a ex. amiga armou contra ela por ciúmes de Alex. Naquele momento, Jessica de fato acredita nisso, mas ao longo da primeira e segunda temporadas descobre que até a afirmação mais grave de Hannah era verdade e percebe que, apesar de terem brigado, ela continuou lhe ajudando quando pode. Em seu testemunho, na segunda temporada, ela fala de Hannah com muito carinho. Como vimos anteriormente, a memória prega peças: talvez, sobre alguns eventos, elas se lembrem de forma diferente sobre o que ocorreu, quem deixou de ir primeiro ao café e quem passou essa percepção para a outra, mas sobre outros fatos ela pôde confirmar que Hannah disse a verdade.

Zach, tendo uma prova nas mãos de que parte do discurso de Hannah é falso, lança dúvidas sobre ele: nunca jogou fora a carta que Hannah lhe mandou, conforme ela o acusou. Como ele mesmo disse a Clay, ela pode ter dito isso por achar que foi o que ele fez, ou pode ter mentido, sabe-se lá por qual motivo. Contudo, é interessante notar como um detalhe equivocado pode corroborar para por em xeque toda uma história. A situação impõe dúvidas à Clay. Talvez Zach possa ser o personagem que mais conturba a visão de Clay sobre Hannah. Na segunda temporada, quando ele revela em tribunal que eles tiveram um relacionamento, Clay se sente revoltado por não saber disso e fica com uma certa inveja. Ao mesmo tempo, a omissão desse fato por Hannah nas fitas o leva a questionar toda a história que ela construiu. A verdade não deveria excluir eventos relevantes, sob o risco de ser contorcida.

Há também os que discordam do discurso de Hannah em considerá-los culpados, como é o caso de Courtney. Ela defende que foi Hannah quem escolheu o seu destino, e não eles. Clay a leva ao túmulo de Hannah para confrontá-la. Não querendo assumir a sua homossexualidade, ela declara falso o que Hannah disse. Só no tribunal, na segunda temporada, quando a advogada tenta conduzir seu testemunho para que diga que Hannah queria algo com ela e a manipulava, é que Courtney decide revelar seu segredo. Defende Hannah, dizendo que ela foi sempre 
uma boa amiga, confessa que se sentia atraída por ela, manipulando a situação e, por medo de se expor, acabou expondo Hannah.

Houve também aqueles que se abalaram fortemente com suas fitas, como Alex. Hannah fala em suas gravações em alto e bom som que aqueles que receberam suas fitas são responsáveis por sua morte. Que todos os responsáveis saberão uns sobre os outros. Alex se sente culpado. Reconhece que atrapalhou a amizade entre ele, Jessica e Hannah. Pensa que se não tivesse afastado Jessica de Hannah talvez ela não tivesse se matado, pois teria ao menos uma amiga. Considera que ela ter morrido é culpa dele e de todos. Fica tão abalado que tenta acabar como Hannah, mas erra o tiro.

No tribunal, na segunda temporada, Tyler diz que ele sabe que o que está presente nas fitas de Hannah não é toda a verdade, o que não significa que as fitas estivessem cheias de mentiras, mas sim que a verdade é algo mais abrangente, englobando partes de um quadro maior do que ela pintou. Será que ela escondeu certos eventos para proteger alguns dos citados? Ou para se proteger?

As palavras de Hannah que finalizam a primeira fita dizem que Justin provavelmente não queria desapontá-la, assim como alguns outros que estavam ouvindo nem tinham ideia do que estavam fazendo, mas iriam descobrir pelas fitas.

Enquanto a defesa argumenta que o objetivo de Hannah com as fitas era contar o que lhe aconteceu, para que a próxima garota a passar por isso não se sentisse sozinha, e lembrar da importância das pessoas serem gentis umas com as outras, a advogada da escola acusa Hannah de querer que quem escutasse suas fitas sofresse, como as pessoas que fizerem bullying a fizeram sofrer, devolvendo assim na mesma moeda. A advogada acredita que o fato de pessoas cometerem erros não dá a Hannah o direito de puni-las.

Hannah não foi a única que quis punir aqueles que ela acusa. Clay e Tyler também tiveram seus momentos.

Clay sempre caminhou em linhas tortuosas, ora acreditando, ora questionando se Hannah dizia a verdade e se perguntando por que ela havia escondido fatos. Imagina se caso ele tivesse permanecido na cidade no verão, a história de amor de Hannah poderia ter sido com ele e não com Zach. 
O momento mais duro para ele foi quando começou a questionar quem Hannah realmente era, devido ao fato de ter sempre novidades possíveis de incluir em sua biografia. Ele chega à conclusão de que Hannah havia beijado grande parte da escola e isso o enlouqueceu. Em uma de suas epifanias, Justin olha para ele desconcertado e pergunta se ele achava que só porque ela namorou um, o beijou, beijou outro, de repente havia se tornado uma pessoa que ele não conhecia, uma vadia. Justin diz que nem sabe com quantas garotas já se envolveu, que se surpreendia dele julgá-la de maneira tão rasa e achar que toda a identidade dela pudesse ser abalada por isso.

Na primeira temporada, apesar de suas dúvidas, Clay acaba romantizando Hannah, ainda que ela sempre o critique e exija que ele fale o que ela quer ouvir, ou espere que ele atue de maneira contrária ao que ela mesma disse. Na segunda temporada, ela é humanizada. Clay percebe que ela está muito longe de ser perfeita, mas que, nem por isso, deixa de ser digna de seu amor.

Clay concilia seus sentimentos e a memória de Hannah. Em seu velório, finalmente consegue se despedir de seu fantasma e decide que pode continuar gostando dela, sem que isso o impeça de seguir em frente, tirando ensinamentos para a vida das fitas e de sua relação com Hannah.

Olívia entrega a Clay uma lista feita por Hannah, descoberta no computador da farmácia, em que ela enumera seus motivos de porque não se matar. Clay está em dois motivos, dentre onze. A mãe de Hannah diz a Clay que, diferentemente do que concluiu a filha, sempre existem mais motivos para se viver. 


\subsection{Construção narrativa}

Em toda a narrativa, diferentemente do que ocorre em The Affair, a imagem da câmera, em geral, mostra algo que faria mais jus a uma realidade objetiva, com algumas exceções.

A construção narrativa varia nas três temporadas, alguns mecanismos são mantidos, outros mudam pelas próprias demandas da história de cada temporada, outros são retomados. De uma maneira geral, os artifícios que mais marcam a narrativa de Thrirteen Reasons Why para efetuar as trocas entre temporalidades são: os planos pontos de vista e os planos detalhes; as silhuetas sombreadas que cruzam as cenas; a presença da mesma locação, entrecruzando tempo passado e presente; as mudanças de cores; e as marcas corporais, como cicatrizes e mudanças de caracterização.

Veremos a seguir como o uso de cada um desses recursos afeta a narrativa nas temporadas. Elas não usam esses recursos de maneira semelhante, o que pode estar relacionado com a configuração do enredo ou com decisões criativas de outras ordens, mas a maior parte deles se perpetua pela série. Curiosamente, como já disse, assisti a primeira temporada da série, que é a que mais utiliza a maior parte desses recursos, sem pensar em analisá-la. Nesse primeiro momento, a agilidade da narrativa me encantou, mas só depois, quando parei para analisar a série minuciosamente, foi possível identificar os recursos que propiciavam seu ritmo.

\section{Plano ponto de vista, plano detalhe, silhuetas e locais semelhantes}

Reuni esses quatro recursos em um mesmo item, pois juntos eles são responsáveis pela impressionante agilidade com que a narrativa da série opera, principalmente na primeira e na terceira temporada.

Vimos que o plano ponto de vista foi utilizado em The Affair para pontuar a troca de olhares e chamar atenção para certos aspectos que estavam sendo observados, o que podia confirmar ou desdizer a narração. Em Thirteen Reasons Why, seu uso tem o papel, principalmente, de evocar as trocas entre temporalidades. Mas claro que também pode, em alguns momentos, demarcar trocas de olhares entre os personagens ou revelar que determinada cena foi observada por um outro personagem. 
Para efetuar essas trocas é de extrema relevância o fato das cenas em que são entrelaçados presente e passado possuírem uma locação comum. Assim o plano do olhar de um personagem visualiza ora o tempo presente, ora o tempo passado. Em geral, ele é um plano ponto de vista fechado, que vai e volta do plano do olhar, passando pelo plano ponto de vista. É comum que essa mecânica se repita mais de uma vez, formando um plano ponto de vista múltiplo.

Uma cena que apresenta esse recurso é quando Clay, na cafeteria, visualiza o passado, observando Hannah olhando para Jessica e Alex em clima de romance. Hannah passa por trás de Clay, que é um intruso na cena em um tempo que não lhe pertence. O plano do olhar de Clay também parece observar Jessica e Alex. Quase no mesmo instante em que Hannah passa por trás de Clay, uma silhueta passa pela frente do personagem. O efeito que essa silhueta produz, ao passar, é alterar sutilmente as cores da imagem, que passam a ser ligeiramente mais azuladas e escuras. Quando é revelado o plano ponto de vista de Clay, já estão no quadro Jessica e Alex no tempo presente. A câmera volta para o plano do olhar do protagonista e novamente para seu plano ponto de vista, onde o ex. casal está em cena com uma aparência bem distinta à do plano ponto de vista de Hannah, apresentando rostos preocupados em sintonia com o teor de sua conversa.

Figura 12 - Plano do olhar de Hannah e Clay, olhando Jessica e Alex em temporalidades diferentes.
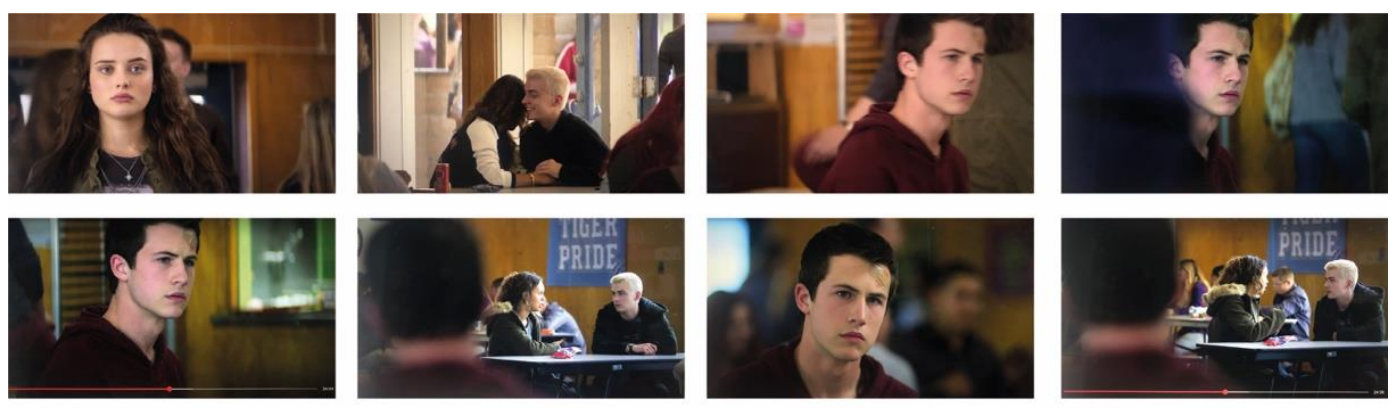

Na segunda temporada, o plano ponto de vista é substituído em sua maioria por um flashback, que vem após um close no personagem, revelando que ele se lembra de algo. Ele não mais visualiza a cena, como na primeira temporada, por conta de não estar no mesmo espaço.

Na primeira temporada, também existem flashbacks que funcionam dessa forma. No primeiro episódio, por exemplo, ainda antes de Clay receber as fitas, ele 
passa de carro com Tony pelo cinema onde trabalhou com Hannah. Na hora temos um close seu, seguido por uma cena de lembrança dele lá com a amiga. Esta recordação é cortada pelo som de uma buzina, que o convoca novamente ao momento presente. É muito comum o uso de recursos sonoros para interromper as narrativas do tempo passado.

O plano detalhe, operado em conjunto com a presença no mesmo local, também permite a ágil costura entre tempos. Um exemplo é a cena em que a mãe de Hannah pede a Clay que lhe ajude a entender o que aconteceu com Hannah. Ele estava pedalando, até que viu que a casa de Hannah estava sendo vandalizada por garotos com rolos de papel higiênico. Ele os expulsa e começa a recolher os papéis. Olivia sai da casa, inicialmente achando que era ele que tinha feito aquilo. Ele lhe explica o ocorrido e se apresenta. Ela, então, o chama para entrar. É interessante observar que, no segundo exato em que a porta se fecha no presente, a luz ao lado da porta se acende no tempo passado e se ouve um pequeno ruído. Quando a porta se abre, saem primeiro o pai de Hannah e depois sua mãe, no tempo passado, deixando Hannah e Courtney a sós, tramando uma armadilha para o stalker de Hannah. A presença da luz torna a cena mais clara, comum no tempo passado.

Figura 13 - Clay e Olívia entram na casa no tempo presente, saem os pais de Hannah no tempo passado.
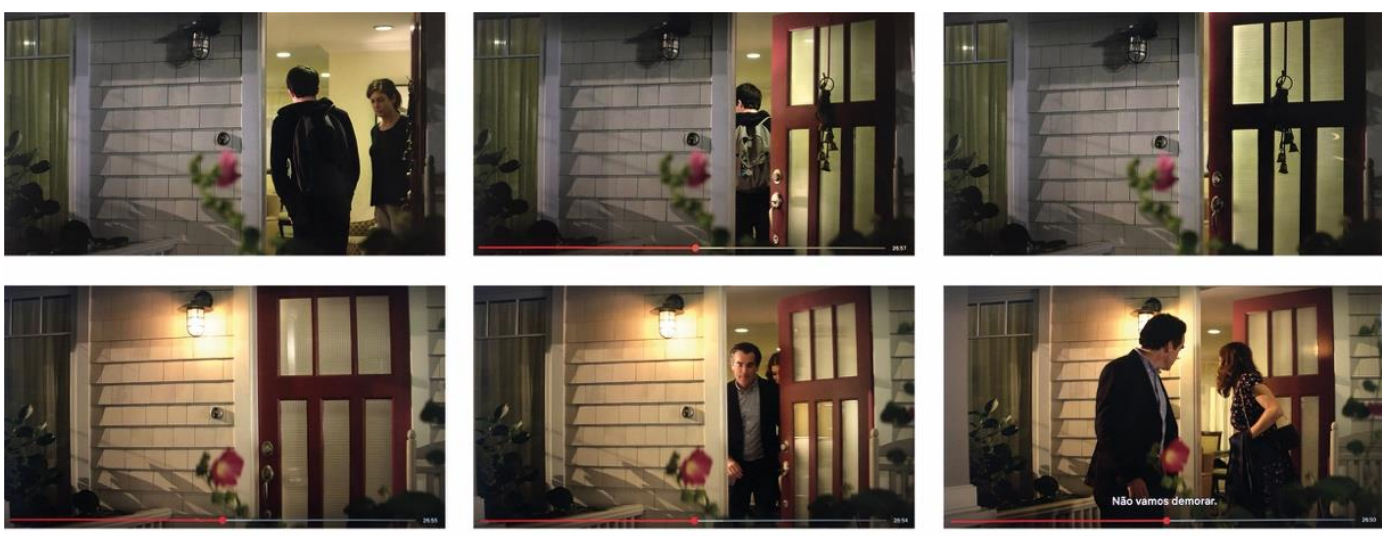

Após a saída dos pais, Hannah oferece uma bebida a Courtney e se abaixa para pegá-la em um móvel, no tempo passado. No que parecia ser o plano detalhe da cena, uma mão pega a bebida, mas, no plano seguinte, percebe-se que foi Olívia que realizou essa atividade, no tempo presente. 
Figura 14 - Plano detalhe propiciando a mudança de temporalidade.
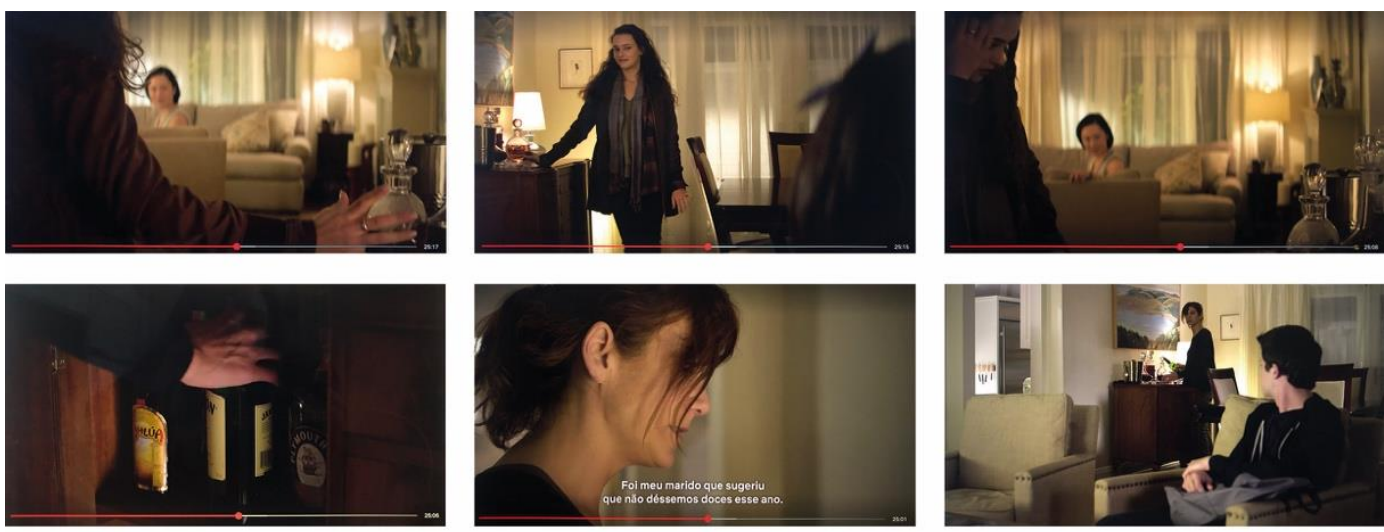

Olívia diz à Clay que Hannah não tinha muitos amigos e pergunta se ela alguma vez mencionou algo que indicasse que ela poderia estar sofrendo bullying. Ele se esquiva, dizendo que Hannah não lhe falava sobre essas coisas, que eram mais conhecidos que amigos. Ela desabafa com Clay. A imagem revela que ele mostrou a fita para Olivia, que agradece e diz que agora sabia quem era o responsável e começa a enforcá-lo. Clay lava o rosto no banheiro e sua visão horrível se mostra apenas fruto de sua imaginação. Ao ver o quarto de Hannah, seu plano ponto de vista revela o passado, dando seguimento à história da gravação, em que Hannah e Courtney se beijam e descobrem que foi Tyler quem tirou as fotos. Clay retorna ao tempo presente no momento em que Olívia o chama e aparece no quarto. Ela diz que vai buscar uma caixa com coisas de Hannah, o que permite a Clay ver o final da história do tempo passado: Courtney corre da casa de Hannah, estressada por saber que o stalker era alguém da escola, deixando Hannah desolada; no presente, é Clay que sai correndo da casa de Hannah, dizendo que estava atrasado para o jantar, deixando Olívia desolada. Ambas compartilham o mesmo quadro e sentimento: passado e presente juntos. Essa presença mútua acontece em algumas cenas.

Figura 15 - Presença mútua de personagens de temporalidades diferentes no mesmo quadro.
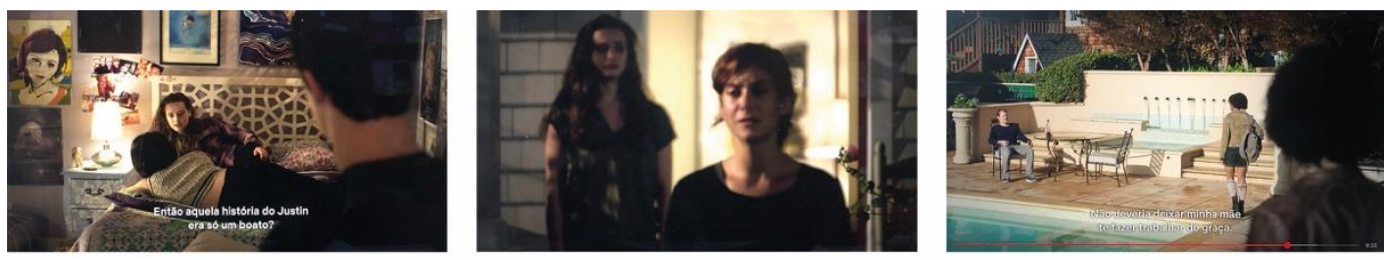
Na primeira imagem é possível ver Clay do presente em cena, observando Hannah e Courtney no tempo passado; na segunda, Hannah no tempo passado e Olívia, no tempo presente, compartilham o mesmo quadro; e na terceira, Ani do tempo presente observa ela mesma e Bryce no tempo passado.

Mas o plano detalhe não foi usado apenas para cenas em um mesmo lugar. Em alguns momentos, o plano detalhe pode servir como gancho para cenas em outros locais. Há um momento, por exemplo, em que Ryan, na escola, retira da lixeira um cartaz da campanha anti suicídio, jogado fora por Alex. No tempo presente, Ryan conversa com Clay sobre os cartazes, e a cena seguinte, que corresponde a uma lembrança de Clay, se inicia em um plano detalhe de uma lixeira, onde se veem sacos de pipoca amassados. A câmera abre, mostrando Clay e Hannah organizando o lixo do cinema. Eles aproveitaram um objeto para criar a costura entre as cenas.

Cenas de carro também entrelaçam passado e presente, podendo conter os mesmos personagens em ambas as temporalidades, ou personagens diferentes.

Figura 16 - Cena no carro de Clay do tempo passado costurando com cena do tempo presente, na terceira temporada.
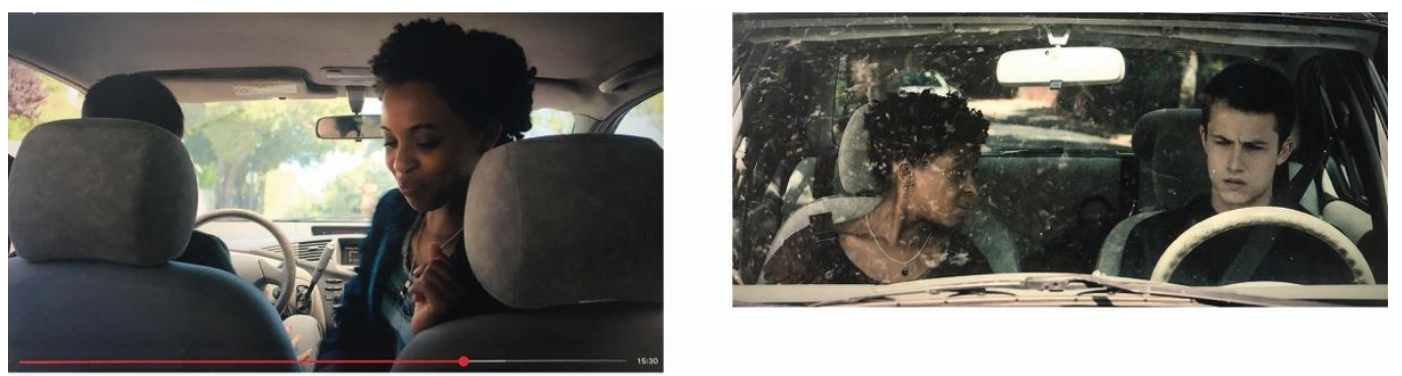

Um exemplo de outra cena em que um objeto conecta os tempos é quando Clay vai comprar um pacote de skittles na escola, no tempo passado, em uma máquina de venda de produtos. Ele ouve o senhor Porter e a professora Pam Bradley conversando sobre Hannah, o que é revelado por seu plano do olhar e, na sequência, por seu plano ponto de vista. A câmera alterna entre esses dois planos até o momento em que eles percebem que Clay os olha. O garoto então, se abaixa para pegar suas balas e sai da escola o mais rápido possível, passando por uma porta. Quando ele sai, já está no tempo passado, no exterior do cinema, com seu uniforme 
de trabalho, o pacote de skittles na mão e um copo de refrigerante. Ele caminha até o local onde está Hannah, para comer e conversar com ela.

Figura 17 - Pacote de Skittles acompanha Clay na passagem de tempo.
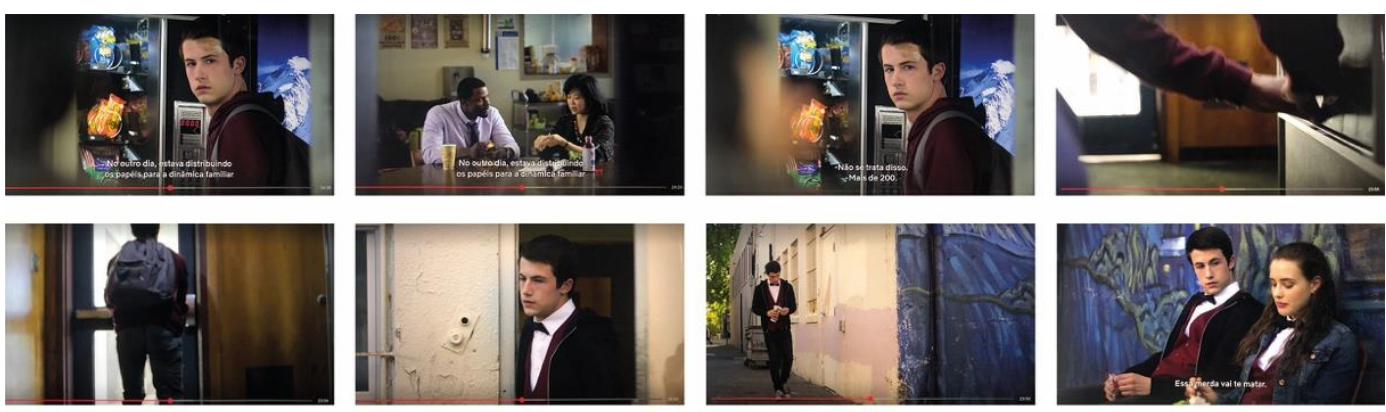

No primeiro episódio, a professora Pam Bradley conversa com a turma sobre o que podem fazer para ajudar aqueles que notarem que não estão bem. Clay olha saudoso para o local onde Hannah costumava se sentar. Vemos o seu plano do olhar, depois seu plano ponto de vista com a carteira vazia. A professora cruza o plano ponto de vista de Clay e, por trás de sua silhueta, a roupa da colega em quadro muda, indicando a troca de tempo, e surge a imagem de Hannah. Esse movimento se dá de maneira muito rápida, parecendo que Hannah aparece em sala como em um passe de mágica. É o tempo passado que se configura, mostrando um momento de aula que eles vivenciaram. Em um dado momento, a voz da professora o chama, fazendo com que saia de seu transe e volte ao tempo presente. É possível notar que a professora usa o mesmo casaco no tempo passado e no tempo presente. No presente a blusa que usa é berinjela escuro e a imagem mostra que no passado era rosa. 
Figura 18 - O tempo passado se revela com a passagem da professora pelo plano ponto de vista de Clay.
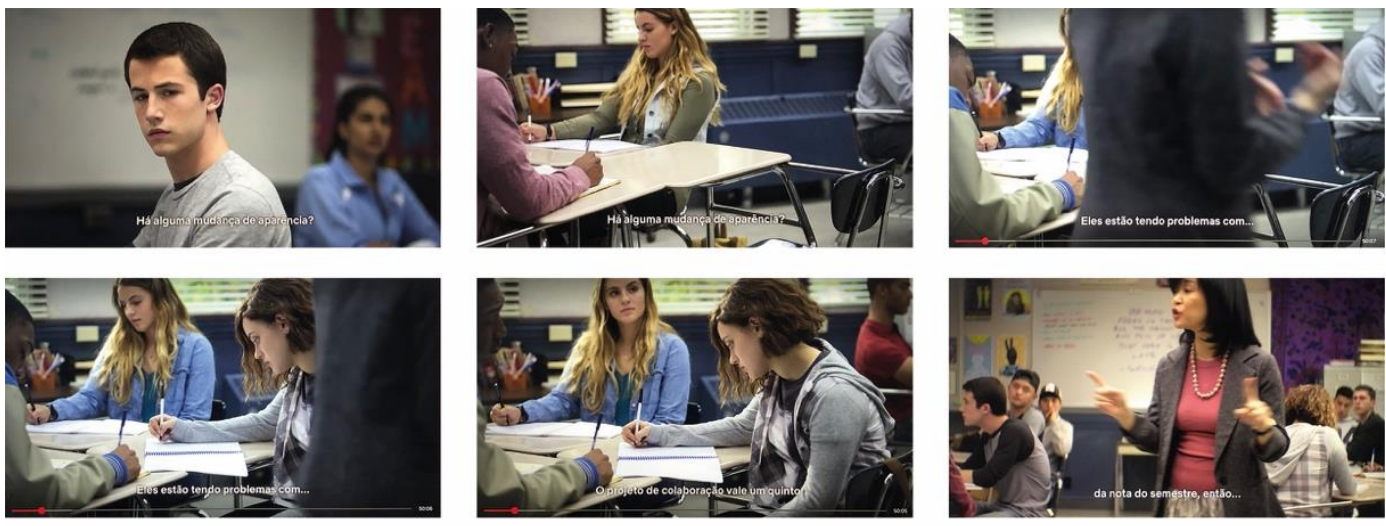

O uso de transeuntes cruzando a câmera, passando pelo plano ponto de vista dos personagens na frente dos objetos de seu olhar, é comum a todas as temporadas. $\mathrm{Na}$ primeira, ele frequentemente propicia o aparecimento ou desaparecimento de Hannah, ou ainda outras costuras temporais entre tempo passado e tempo presente. A terceira temporada recupera fortemente esse recurso para realizar o entrecruzamento de tempos, operando junto ao plano ponto de vista.

Na primeira cena da série, Clay visualiza Hannah em sua lembrança, como se ela estivesse em seu tempo presente. Alguns alunos passam entre os dois, e ela desaparece no momento em que as silhuetas de dois transeuntes se cruzam, deixando a tela totalmente escura por frações de segundo. Tudo acontece tão rápido que foi difícil até consegui parar o vídeo no momento certo para fotografar.

Figura 19 - A imagem de Hannah da recordação de Clay some com o passar dos transeuntes.
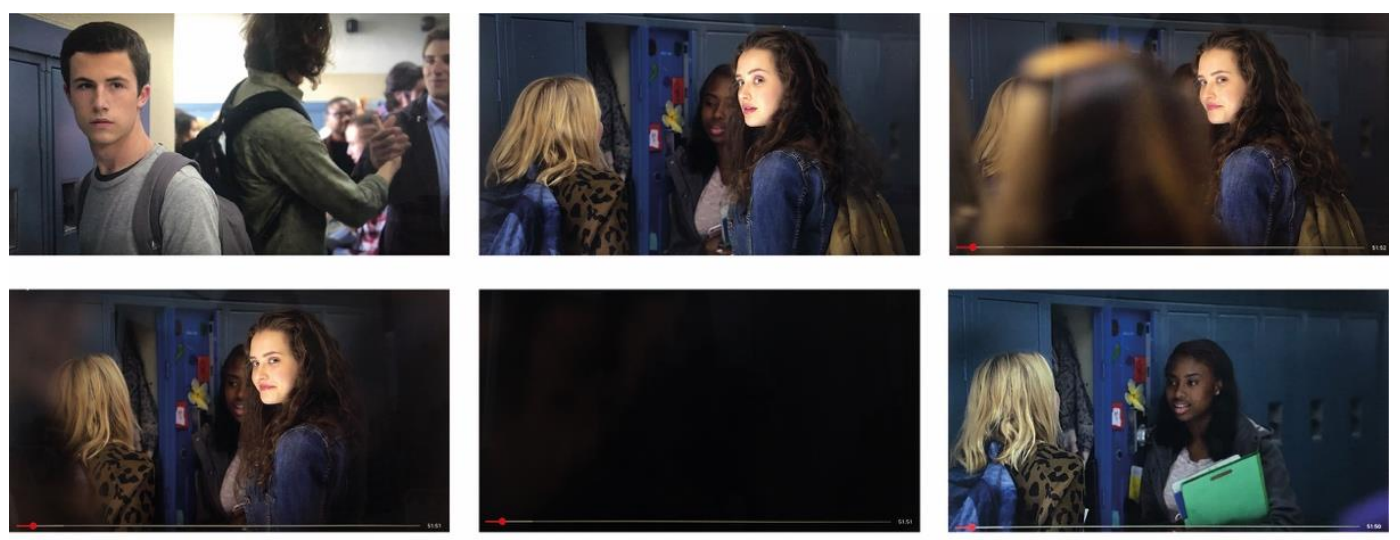

A terceira temporada faz grande uso também das silhuetas e do plano ponto de vista. Há uma cena em que a silhueta é constituída pelo personagem sentado na 
frente de Clay numa mesa e que é o giro da própria câmera que aproveita essa silhueta para revelar uma nova temporalidade: o Clay do passado que conversa com seus colegas na mesma mesa.

Figura 20 - Giro que faz o passado aparecer por trás da silhueta.
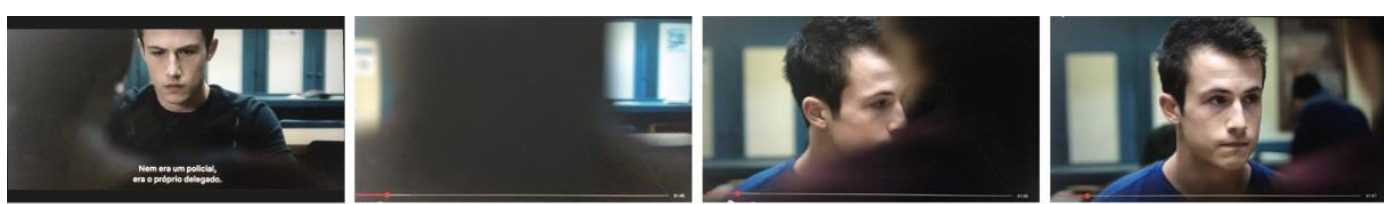

Recursos que ajudam a evidenciar a que tempo pertencem os personagens são algumas marcas corporais e formas de caracterização. A cicatriz do acidente de bicicleta sofrido por Clay no primeiro episódio da série, indica, durante quase toda a primeira temporada, que ela faz parte do tempo presente e, portanto, sua versão sem cicatriz faz parte do tempo passado. Na terceira temporada, no jogo de boas vindas, que representa o último dia do tempo passado, quase todos os personagens brigam, ficando com visíveis machucados, que demarcam com facilidade o tempo presente. Na primeira temporada, enquanto Hannah estava viva, sua mãe costumava estar com o cabelo solto e vestir roupas com cores alegres. Após a morte da filha, seu cabelo está quase sempre preso e ela usa cores mais fechadas.

É possível notar que o emprego de todos os mecanismos citados acima cria uma narrativa ágil, que ocorre com precisão na primeira temporada. Isso aliado a cenas curtas e diálogos rápidos imprime um ritmo acelerado.

Figura 21 - Diferentes planos de uma mesma cena de menos de 1:37'.
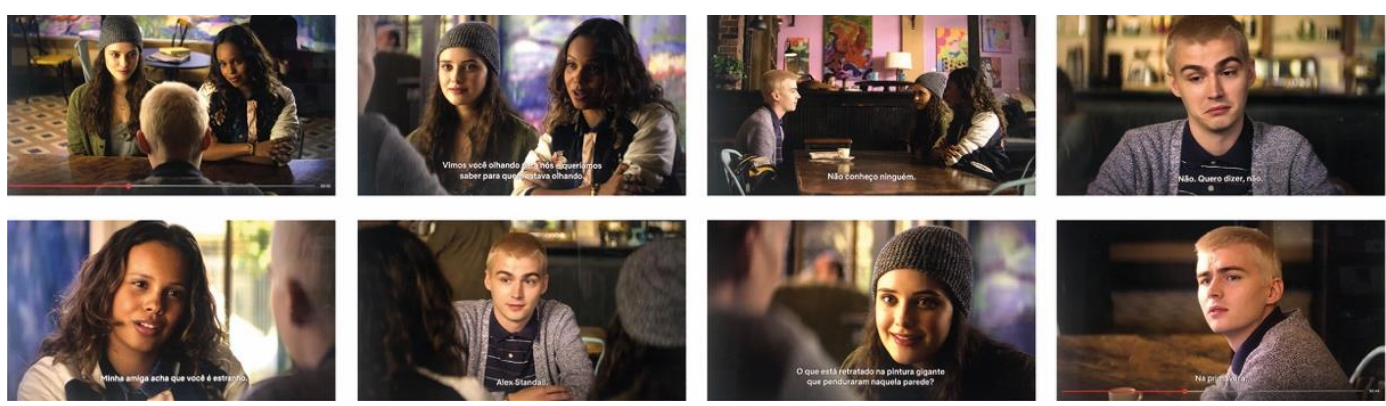
$\mathrm{Na}$ primeira temporada, a maior parte das cenas mais longas utiliza movimento: um plano contínuo acompanha os personagens que se locomovem no espaço, seja andando nos corredores da escola, no pátio ou de bicicleta.

Figura 22 - Câmera acompanhando personagens.
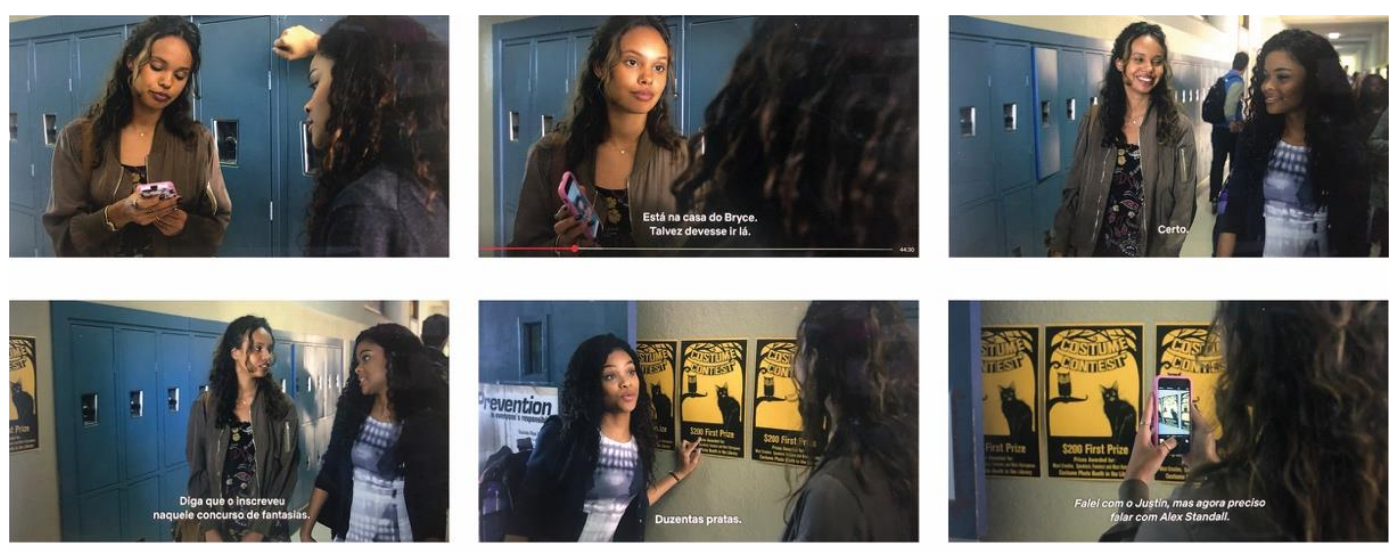

A segunda temporada perde essa dinâmica. O público nota a perda do ritmo, comentando sobre isso nas redes sociais, ainda que não necessariamente identificando os motivos. Acredito que os dois fatores que mais contribuem para essa sensação de perda de ritmo são a estrutura e os diálogos. Por estrutura me refiro ao fato da trama do tribunal ser a maior responsável por evocar os flashbacks, que não se passam no tribunal, não permitindo que sejam usados com frequência os mecanismos acima citados, consagrados pela primeira temporada. Também tem sua parcela de culpa o fato das cenas terem se tornado mais longas e com menos cortes. Os diálogos são mais extensos, principalmente no início da temporada, onde abusam de diálogos expositivos, que explicam majoritariamente questões ligadas ao tribunal, apresentando mais palavras que ações.

Contudo a série mantém seu público cativo, que já tem afeição por seus personagens. Já há o interesse por suas histórias: os fãs querem saber que rumo esses personagens tomarão e se envolvem ao ver toda a narrativa já apresentada ressignificada, além de se sentirem instigados a descobrir sobre os novos mistérios que se apresentam.

A terceira temporada recupera os mecanismos que proporcionam agilidade à narrativa, principalmente o ponto plano de vista e a passagem de transeuntes que entrelaça cenas em um mesmo espaço. Seu primeiro episódio apresenta um ritmo 
impressionante, não deixando nada a desejar frente aos episódios da primeira temporada, o que não se repete nos episódios que se seguem. Reparei que o motivo principal foi terem focado em uma única trama: um deles fala sobre a superação de Jessica e outro sobre a decisão de Chloe, apoiada por Zach, de abortar o filho de Bryce que carregava em seu ventre. Nos outros episódios em que tramas de diferentes personagens se misturam, a narrativa torna a parecer mais ágil, chamando atenção para o fato da costura entre diferentes tramas também contribuir para o ritmo. Um recurso que a terceira temporada intensificou foi o uso da cor e da forma da tela para diferenciar as temporalidades.

\section{Demarcação de temporalidade pela cor e pela forma}

A cor é um elemento fortemente explorado na construção narrativa de Thirteen reasons why, demarcando a mudança de temporalidade de maneira sutil, na primeira e segunda temporada, e enfaticamente, na terceira temporada. Cada temporada tem os seus nuances específicos.

Como, nesse caso, as imagens comunicam melhor que palavras, vou partir delas para traçar comentários, começando com a comparações do uso de cores entre as diferentes temporadas. 
Figura 23 - Diferentes tons de azul no armário.
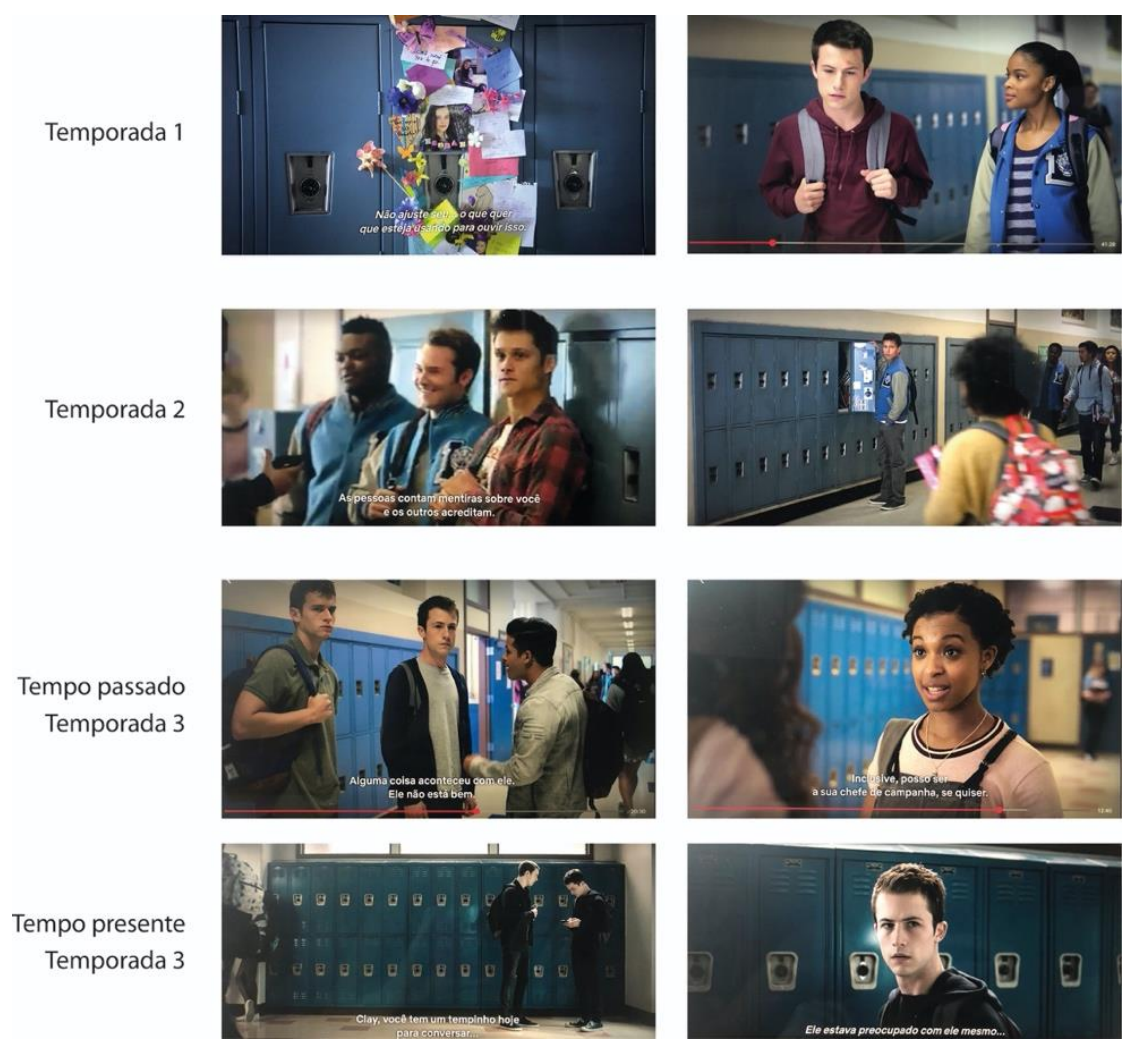

Só por essa imagem já é possível observar as diferenças de tonalidade entre as temporadas e também de tamanho da tela. A primeira apresenta o azul em um tom mais forte, na segunda o tom é um pouco mais lavado, mas apenas olhando para as imagens não seria fácil identificar se elas pertencem à primeira ou segunda temporada. Também a variação de tom entre passado e presente nas duas primeiras temporadas é mais sutil que na terceira, por isso não destaquei na figura. A terceira temporada varia a cor de maneira significativa: o passado é mais claro e mais saturado, enquanto o presente mais escuro, percebendo-se claramente a manipulação das cores.

Nota-se também a diferença entre os tamanhos das telas. Como vimos anteriormente, a tela da primeira temporada é widescreen 16:9, aspect ratio de 1.78, a da segunda é mais estreita, com aspect ratio de 2:00 e a terceira temporada alterna formatos diferentes de tela, no tempo passado, widescreen semelhante à primeira temporada e, no tempo presente, uma tela de aspect ratio de 2:22, ainda mais estreita que a da segunda temporada. O tempo presente/futuro também utiliza o mesmo formato de tela que o tempo presente, mas com a imagem em preto e branco tonalizada em sépia, que veremos mais adiante. 
O Monets é um café frequentado em todas as temporadas. Seu visual muda drasticamente na terceira temporada. Na primeira, as imagens são bem coloridas. Na terceira temporada, mesmo no tempo passado em que a imagem é mais clara do que no seu tempo presente, ela não é tão colorida.

Figura 24 - Monets na primeira temporada.
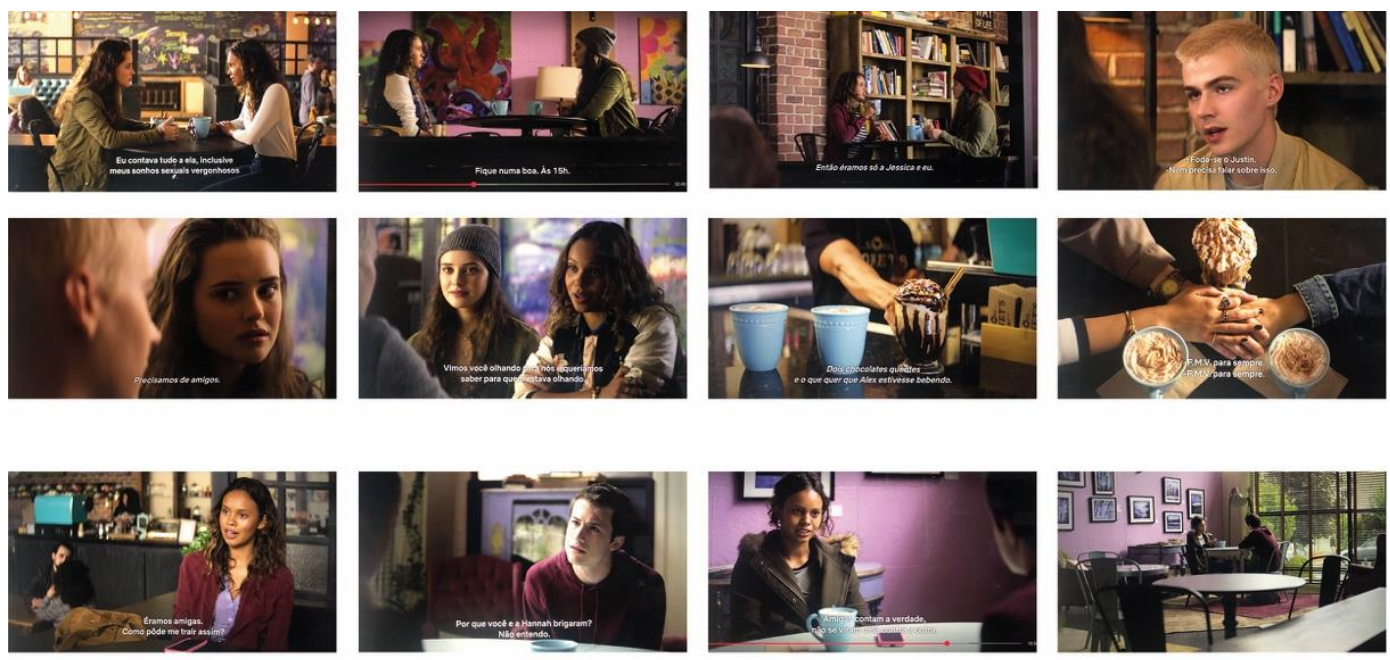

Figura 25 - Monets na terceira temporada, no tempo passado e no tempo presente.
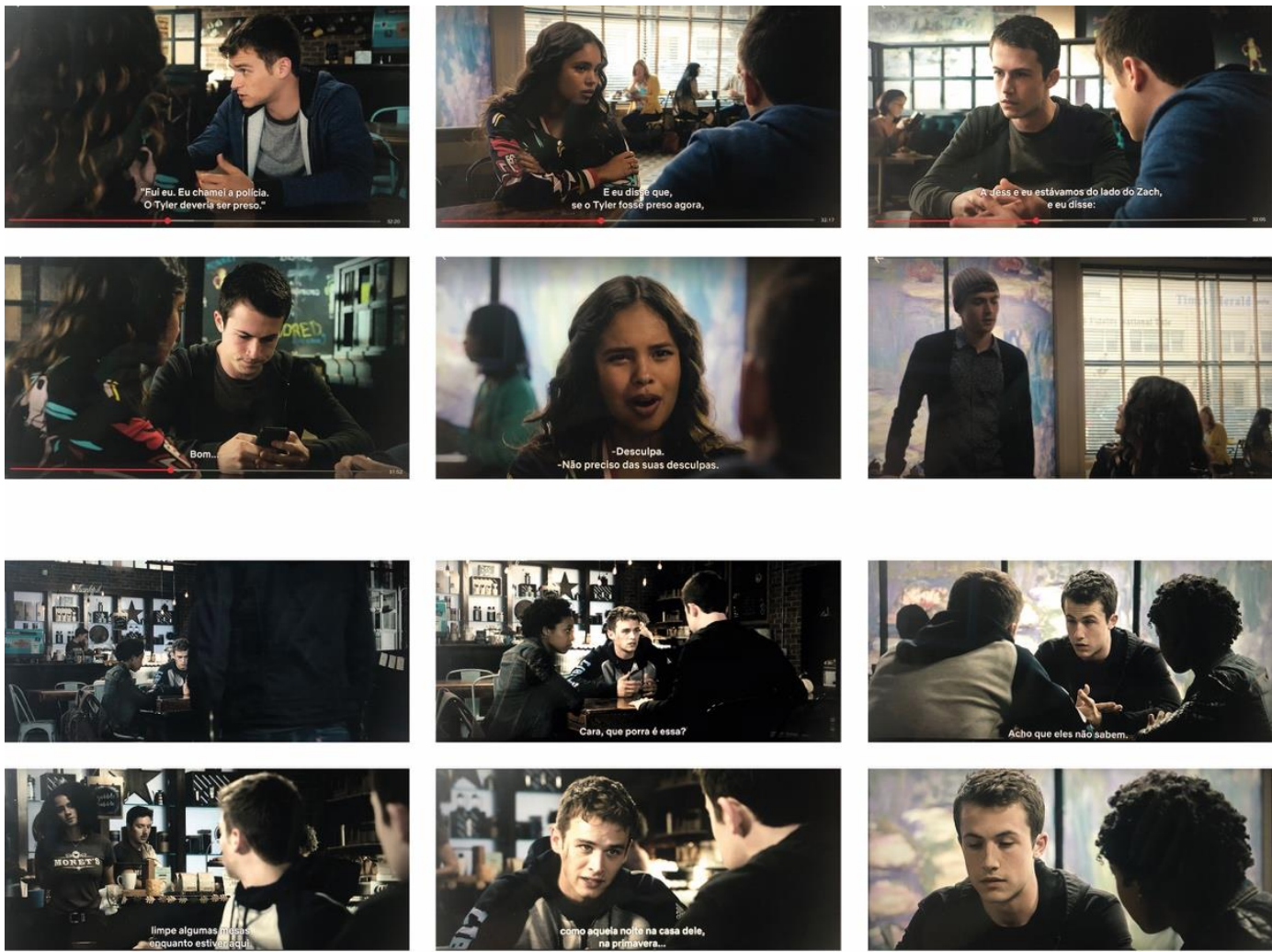
Mas não é só uma questão de luz e de manipulação de cor. O local chega a parecer um outro lugar. Nitidamente, pintaram as paredes de tijolo do café com tinta preta e mudaram seus quadros coloridos para quadros preto e brancos, mantendo apenas os painéis de Monet, que dão nome ao estabelecimento. E mesmo entre as temporalidades da terceira temporada nota-se uma intensificação do preto e do branco no tempo presente (duas últimas linhas da figura 25).

Figura 26 - Diferenças nos tons das cores no tempo passado e tempo presente. (primeira temporada)
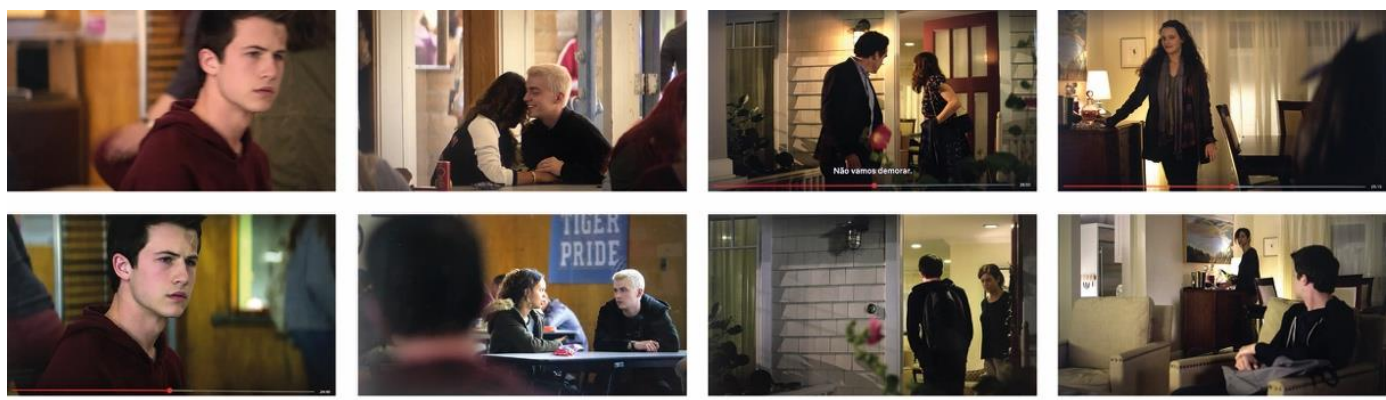

Na primeira temporada, as diferenças no tom das imagens entre passado e presente não são tão díspares. É possível notar que o tempo passado (primeira linha da figura 26) é levemente mais avermelhado e saturado, enquanto o tempo presente é mais azulado e um pouco mais escuro. São percepções passíveis de serem identificadas comparando as imagens de uma cena em um mesmo espaço nos diferentes tempos, mas não é fácil ter certeza de que tempo é a imagem só olhando para a cor, por isso as marcações corporais, como a cicatriz de Clay e as caracterizações dos personagens ajudam muito na identificação.

A seguir, criei quadros cromáticos com cenas de cada uma das três temporadas. Tendo em vista que na primeira e segunda temporada, o tom entre passado e presente varia de maneira bem sutil, mantive ambas as temporalidades em uma mesma cartela. Na terceira temporada, pela variação radical entre as linhas temporais, para cada uma delas foi criado um quadro distinto. 
Figura 27 - Quadro cromático primeira temporada.
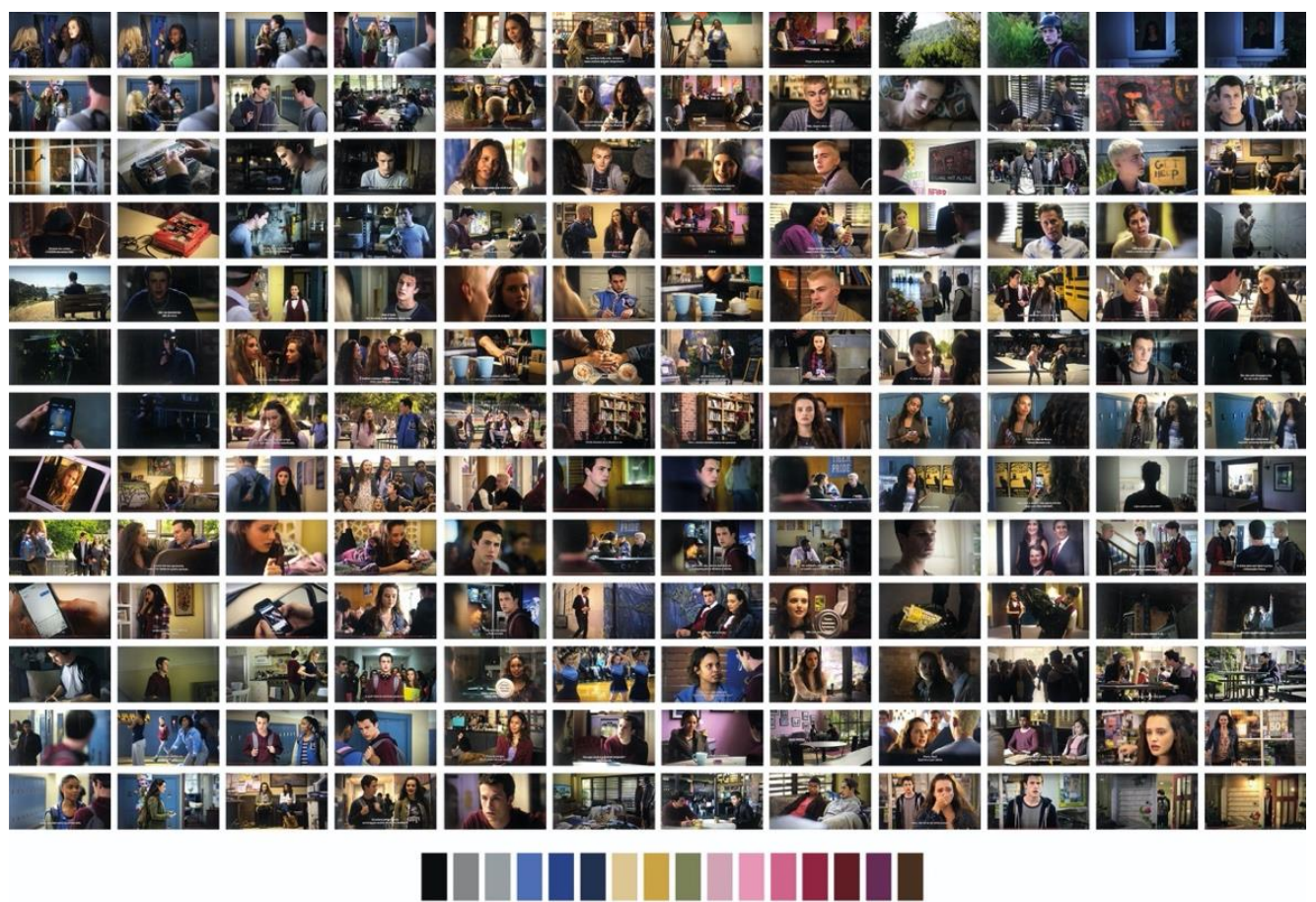

Em todas as temporadas, o azul e o amarelo estão presentes na série e, nessa primeira temporada, é possível identificar que a direção de arte procurou pontuar essas cores nas cenas. Nas roupas, acessórios, paredes e objetos temos mais marsalas, rosas e roxos que nas demais temporadas. Hannah usa muito essas cores, junto a tons de índigo, branco e verde militar.

Figura 28 - Quadro cromático segunda temporada.

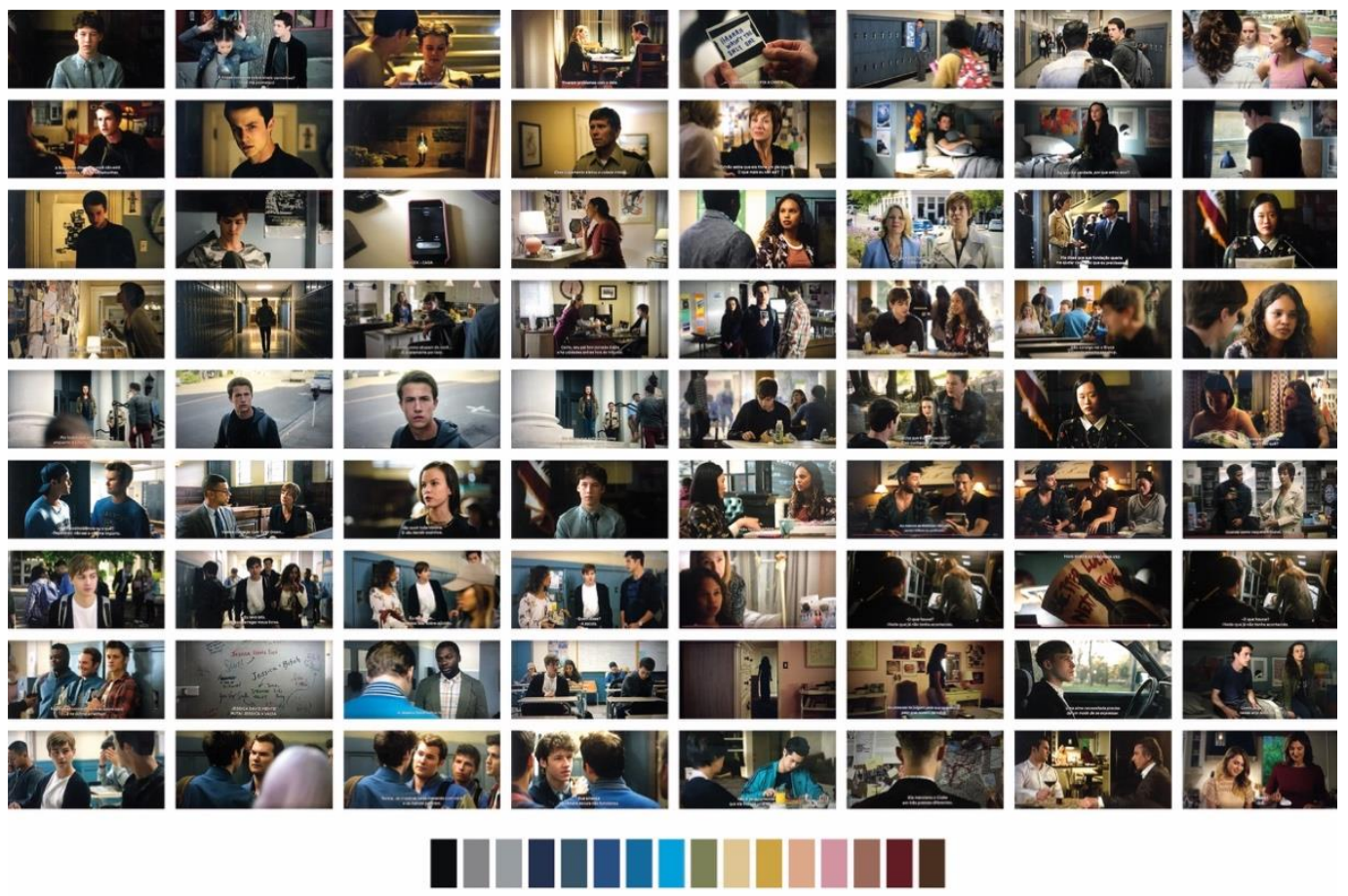


A segunda temporada segue com o azul e o amarelo. Nota-se a forte presença de tons mais neutros, como o cinza. Cores próximas à gama do vermelho quase desaparecem, permanecendo mais os tons pastéis e o rosa claro.

Figura 29 - Quadro cromático terceira temporada - Tempo presente.

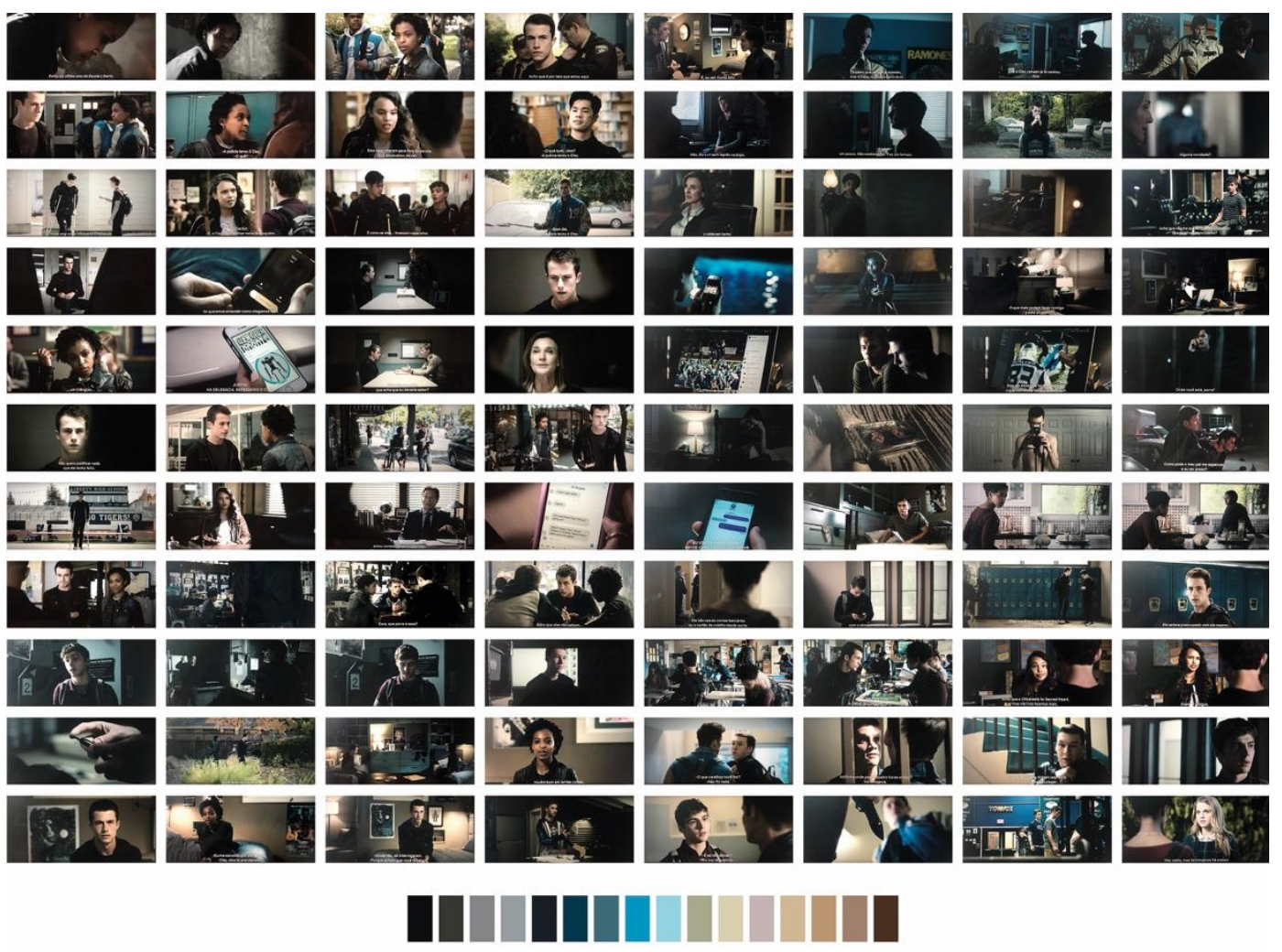

Figura 30 - Quadro cromático terceira temporada - Tempo passado.
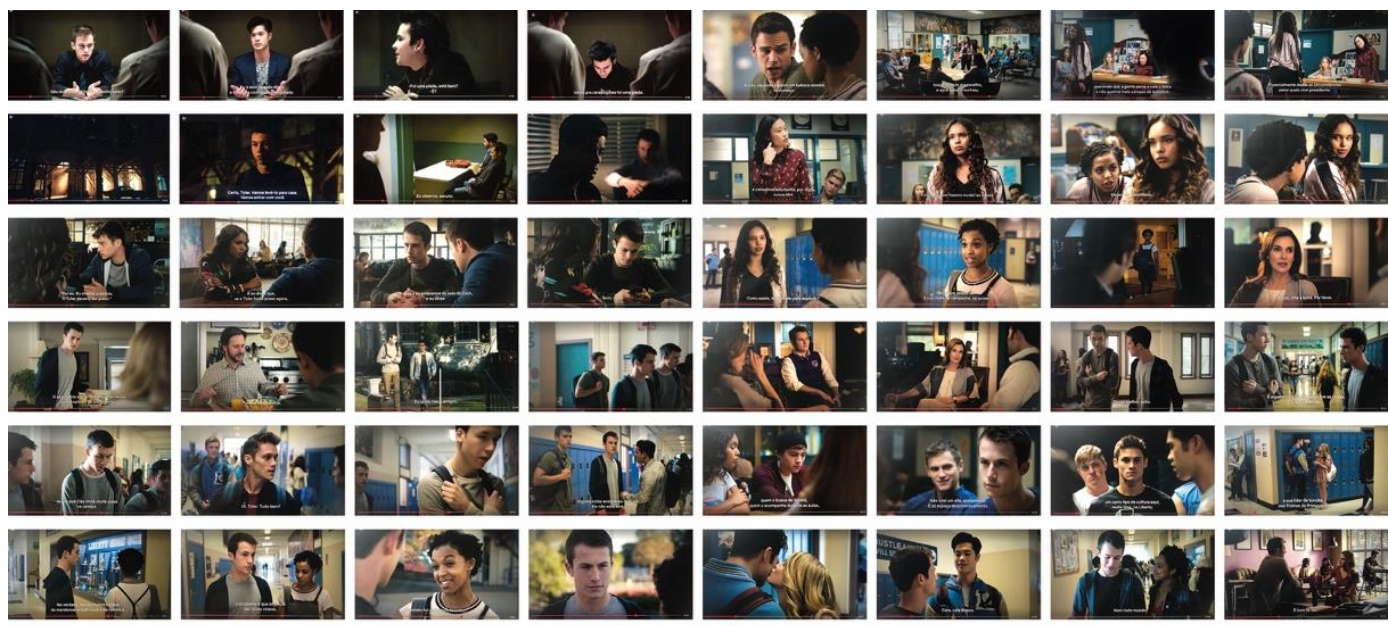

Pif $\mathrm{F}$

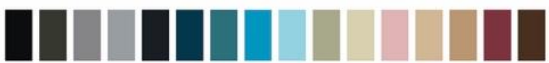


Figura 31 - Terceira temporada - Tempo presente/futuro.
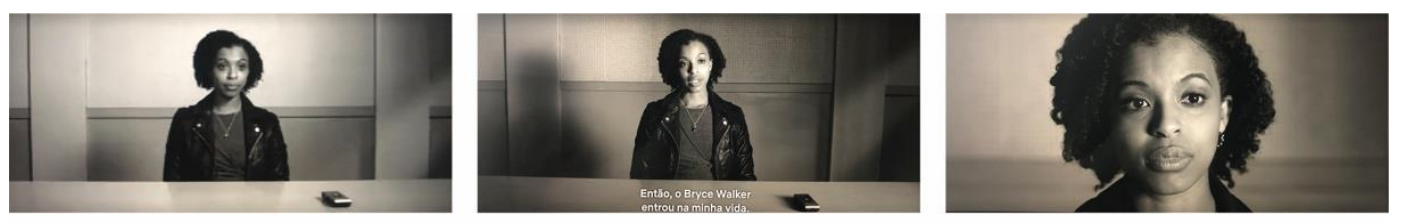

$\mathrm{Na}$ terceira temporada, temos um contraste maior de cores entre tempo passado, presente e presente/futuro. No entanto, ao fazer essa análise cromática, foi possível perceber que a cartela de cores dos tempos passado e presente é muito semelhante. Seu uso é que se difere: no tempo presente o preto, o branco, os neutros e os azuis são as cores mais usadas, junto a uma fotografia mais escura, que cria uma atmosfera mais próxima a de uma série policial. No tempo passado, são escolhidas cores mais vivas e o amarelo, que quase não aparece no tempo presente, volta a ser usado. $\mathrm{O}$ azul segue pontuando as duas temporalidades.

O tempo presente/futuro, tempo do relato de Ani para o pai de Alex, apresenta imagem em sépia, quase preto e branco.

No tempo passado, como a narrativa se inicia em um momento de investigação policial, em que alguns alunos precisam depor sobre a denúncia da presença de alguém armado no baile da escola, situação que alegam ter sido um mal entendido, a imagem também é bastante escura e sombria (primeira e segunda linhas, das quatro primeiras colunas, da figura 30). Depois disso, os quadros ganham mais cor e deixam a aparência sombria restrita ao tempo presente.

Podemos perceber que o uso das cores em Thirteen Reasons Why é realizado com minúcia e que a terceira temporada conseguiu, com uma cartela praticamente semelhante, produzir os efeitos de atmosfera desejados e ainda orientar o espectador visualmente a que temporalidade a cena pertence.

É importante destacar que todos os recursos estruturais identificados não têm o objetivo de expressar a subjetividade dos personagens. A cor, por exemplo, é usada como uma ferramenta de demarcação de temporalidade e para criar uma atmosfera comum a toda temporada. Não tem o intuito de individualizar o momento de cada protagonista, como ocorre, por exemplo, em algumas cenas de The Affair, uma delas descrita na versão de Helen e de Alison, no capítulo 3, no item 3.8. 
As revelações de diferentes pontos de vista se dão no campo das palavras e ações e não no campo da estrutura visual, porém esta proporciona à série um dinamismo que colabora para a narrativa.

Como vimos, a representação da imagem costuma ser mais próxima de uma realidade pretensamente objetiva, por vezes desmentindo o discurso dos narradores que mentem, mas nem sempre. A própria imagem poder ser uma narradora não confiável. Se, por um lado, vemos Marcus mentindo em tribunal, com a verdade sendo revelada na câmera diante de nossos olhos, por outro, vemos Zach jogando no chão uma carta que comprovaremos que ele guardou, tornando essa imagem falsa.

O ponto de vista aqui não corresponde a múltiplas visões imagéticas sobre o mesmo fato sendo representado, mas a uma rede de intrigas entre a construção de mundo e o entendimento de cada personagem.

Como vimos no capítulo 2, a realidade e a identidade estão sempre sendo reafirmadas ou negociadas na interação entre indivíduos. (BERGER; LUCHMANN, 2004, p. 137) Assim a série constrói a sua narrativa acrescentando, com os novos discursos apresentados, novas camadas. Ainda que essas camadas realizem um movimento de construção e reconstrução dos personagens, nesse embate entre suas diferentes visões de mundo é possível manter a empatia, pois eles não se transformam por completo, apenas se tornam mais complexos e mais humanos. 


\section{Multiperspectiva e transmídia}

\subsection{Sobre transmídia e os objetos que serão analisados}

Como dizia Heráclito, "Não se entra duas vezes no mesmo rio", pois além de não se encontrar as mesmas águas, o próprio ser se modifica.

The Lizzie Bennet Diaries (The LBD), produzida em 2012, foi um dos objetos estudados em minha dissertação de mestrado sobre narrativas transmidiáticas (DIAS, 2015). Retorno à análise deste tema e objeto, tendo como objetivo principal perceber como o ponto de vista pode ser trabalhado em uma narrativa transmídia.

Essa série é uma adaptação atualizada do livro Orgulho e Preconceito, de Jane Austen, e foi um case de sucesso precursor de ficção transmídia. Merece não só ser lembrada por seu pioneirismo, mas acredito que o estudo dessa experiência ainda é capaz de contribui para o desenvolvimento de projetos transmídia e reflexões sobre essa forma de narrar. The $L B D$ foi o objeto que me chamou atenção na dissertação para a questão da subjetividade, considerada por Henry Jenkins como uma das sete características-chave da narrativa transmídia, como veremos mais adiante.

Conforme já definimos na introdução e no Capítulo 1, a narrativa transmídia é uma forma de contar histórias através de múltiplas plataformas de mídia, onde os conteúdos destas plataformas se relacionam de modo complementar, expandindo o universo narrativo.

A transmídia deve aliar à presença em múltiplas mídias (multimodalidade), a forte relação entre os conteúdos presentes em cada plataforma, de modo que quantos mais canais forem visitados, mais se saberá sobre o universo narrativo e/ou seus personagens. (JENKINS, 2011, n.p.) Cada plataforma acrescenta ao conteúdo o melhor de suas funções. Por exemplo, se uma das plataformas escolhidas é uma rede social, o que se espera é que sejam bem desenvolvidas as funções de engajamento e identificação com a audiência.

É nesse ponto que a transmídia se difere da chamada crossmídia, que também é uma narrativa multiplataforma, mas que em lugar de expandir o conteúdo narrativo, realiza uma transposição de suporte, adaptando o conteúdo de uma mídia 
para outra. A maioria dos franchisings $s^{33}$ tradicionais se baseou no modelo da redundância, e não da complementariedade.

Esse gráfico, produzido pelo pesquisador inglês Robert Pratten, nos ajuda a diferenciar visualmente esses dois tipos de narrativas multiplataformas:

Figura 32 - Crossmídia x Transmídia.

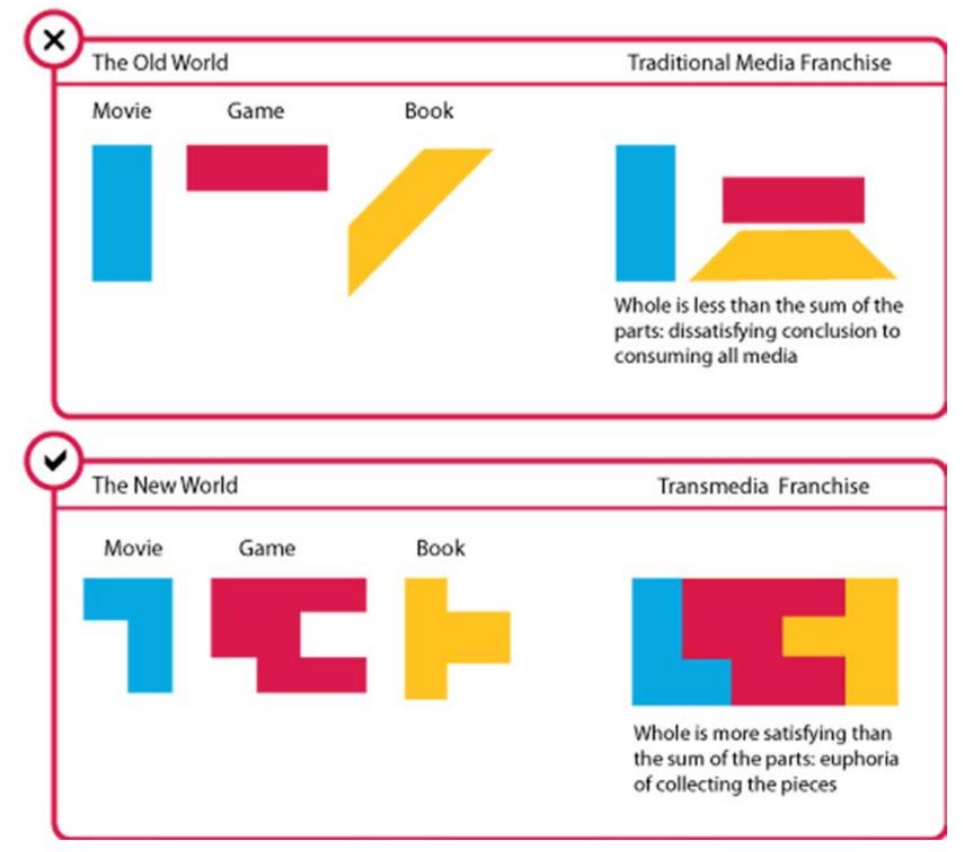

Fonte: TransmediaStoryteller.com, por Robert Pratten.

Como podemos ver na primeira figura, a crossmídia (primeiro gráfico) também utiliza várias plataformas, mas diferentemente da narrativa transmidiática (segundo gráfico), em que as partes estão conectadas, na crossmídia os fragmentos não precisam conversar entre si e seu conteúdo pode ser redundante, pois seu objetivo é alcançar o consumidor por todos os lados, sendo conhecida também como comunicação 360 (graus). No gráfico da transmídia, as partes se

\footnotetext{
${ }^{33}$ Franchise é uma estrutura coorporativa que opera por licenciamento. É um modelo comum tanto para a expansão de marcas do setor do comércio (Mc Donald's, O Boticário, Starbucks, etc.), quanto na produção de mídia. Ela estabelece padrões para que determinados serviços ou produtos sejam reproduzidos de acordo com a forma que já lhes conferiu sucesso. Esse modelo dificultava legalmente que os produtores de mídia pudessem acrescentar algo à narrativa, pois seus criadores limitavam as expansões pelo receio de que sua criação se desvirtuasse, já que outros produtores fariam as adaptações. O franchising tradicional, então, gerou uma produção mais baseada na redundância. (JENKINS, 2011b)
} 
complementam como em um quebra-cabeça. Em simples palavras, a crossmídia corresponde à adaptação de conteúdo e a transmídia à expansão.

A diferença fundamental entre adaptação e extensão é que a primeira adapta uma mesma história presente em um meio para outro, enquanto a segunda busca o prolongamento de um universo ficcional através de cada novo meio.

Christy Dena considera que as adaptações podem ser quase literais ou profundamente transformadoras, pois constituem a interpretação de um trabalho e não uma simples reprodução. Desse modo, toda adaptação em algum grau adiciona significado a uma história. Exemplifica citando o trabalho da equipe de direção de arte de Harry Potter, que teve que traduzir os elementos descritivos do livro visualmente, o que envolveu criatividade. (DENA apud JENKINS, 2011b)

A relação entre os sete livros e os oitos filmes da saga de Harry Potter é uma relação crossmidiática. Os livros contam, do começo ao fim, uma mesma história, a qual os filmes adaptam. Conforme a saga foi se ampliando para novos meios, começaram a aparecer também relações transmidiáticas. $\mathrm{O}$ filme por exemplo, visto junto ao livro Animais fantásticos e onde habitam expande conteúdo em uma mídia diferente. No entanto, convém destacar que se olharmos para a série de livros e a relacionarmos com esse outro livro, não poderemos dizer que se trata de uma relação transmidiática, pois ambos estão presentes na mesma mídia, em livros, ainda que possamos concordar que em ambos os casos houve expansão de conteúdo. Por isso, temos sempre que lembrar que ser ou não transmídia não é um quesito que atesta nenhum tipo de superioridade a outros tipos de narrativas. É só uma forma de narrar que alia múltiplas mídias à presença de conteúdos complementares entre elas.

A narrativa transmídia pode ser considerada uma narrativa hipermidiática. A hipermídia estabelece relações análogas ao hipertexto, porém entre mídias, incluindo imagens, sons e outras formas de dados, além das propriamente ditas textuais. (LANDOW, 1997)

Pierre Levy classifica o hipertexto como uma matriz de textos potenciais. Para ele, o hipertexto é como uma rede constituída de nós, que são os elementos de informação, parágrafos, páginas, imagens, sequências musicais e etc. Esse nós ligam-se uns aos outros pelas referências, notas, indicadores, "botões" que efetuam 
a passagem de um nó a outro e etc. Ainda que o grande exemplo de hipertexto seja a world wide web, Levy não restringe a relação hipertextual apenas às mídias digitais: ele cita a enciclopédia clássica, pois utiliza ferramentas de orientação como índices, dicionários e léxicos. A diferença desta para o hiperlink digital seria a rapidez com que se vai de um nó para outro e a capacidade de misturar na mesma mídia texto, sons, imagens estáticas e em movimento. (LEVY, 1996)

Mas podemos ir ainda mais longe. Os contos de Sherazade nas Mil e uma noites também seguiam a lógica do hiperlink: a partir da associação de ideias ela conseguia contar uma história que não tinha fim e, com isso, mantinha-se viva. Ela expandia conteúdo, nesse caso em uma mesma mídia, assim como o fazem as séries de TV.

Outro termo que se confunde frequentemente com transmídia é multimídia. Alex Primo classifica multimídia como a “combinação de texto, gráfico e elementos de áudio em uma única coleção ou apresentação", a qual torna-se multimídia interativa quando oferece ao usuário "algum controle sobre a informação que é vista e quando ela é vista." Ele ainda acrescenta que a multimídia se torna hipermídia quando se estrutura a partir de elementos interconectados, pelos quais é possível navegar. (PRIMO apud BLANCO, 2011, p.21)

Segundo a associação EraTransmídia ${ }^{34}$, o termo surgiu em 1966 nos Estados Unidos, utilizado pela primeira vez por Bob Goldstein para promover seu show Lightworks at L'Oursin, que unia recursos sonoros, visuais, fogos de artifícios, entre outros, em um mesmo espetáculo. O termo se popularizou com Livro Multimedia making it work, de Tay Vaughan, publicado em 1993.

Multi quer dizer vários, então na multimídia temos vários recursos que são usados de maneira conjunta, podendo ou não estar a serviço de uma narrativa. Os espetáculos do Cirque du Soleil são exemplos que unem teatro, circo, dança, orquestra, palhaçaria, entre muitas outras linguagens, em prol de uma história.

Quando dizemos que The $L B D$ é uma narrativa transmídia precursora é no sentido de ter sido uma das primeiras narrativas de sucesso produzidas tendo em mente uma criação de projeto dessa natureza. A importância da terminologia se dá justamente para que sejam criados projetos que pensem a expansão de conteúdo de

\footnotetext{
${ }^{34}$ Site da associação: www.eratransmidia.com
} 
modo consciente e que sua produção possa ser embasada por conhecimento acadêmico e pesquisas. Contudo, é importante lembrar que antes do termo existir, no sentido institucionalizado por Jenkins, que data de 2003, já existiam experiências narrativas anteriores que poderíamos rotular, anacronicamente, como narrativas transmidiáticas.

Uma delas data do início do século XX. Se engana quem relaciona L. Frank Baum apenas ao filme $O$ Mágico de $\mathrm{Oz}$ : ele criou todo o universo de $\mathrm{Oz}$, com diferentes seres habitando cada reino. Sua obra abrangia peças de teatro, livros, histórias em quadrinhos, entre outros. O homem de lata, por exemplo, que é um personagem coadjuvante no famoso filme, era o protagonista de sua própria série de histórias em quadrinho. Ainda, preocupado com a continuidade de seu universo após sua morte, Baum nomeou um sucessor, que chegou a escrever mais livros sobre $\mathrm{Oz}$ do que ele próprio.

Outro exemplo é Star Wars. George Lucas criou um universo, a partir do qual foi desdobrando narrativas, mas inicialmente não havia a preocupação de que essas histórias mantivessem uma coerência entre si. Isso nos leva a situações como Luke Skywalker em uma graphic novel ter um caso com a Princesa Lea e, no filme, se descobrirem irmãos. Posteriormente, quando já se tinha em mente a construção de universos transmídia como um propósito, George Lucas organizou todos os conteúdos criados pela empresa com um selo de canonicidade, determinando quais eram os produtos que poderiam, juntos, compor uma linha temporal do universo. Separou também o que eram histórias paralelas, fanfictions e o que deveria ser descartado. Quando a Disney comprou a franquia, disse para os fãs esquecerem tudo o que conheciam sobre Star Wars, pois, a partir daquele momento, ela é que iria determinar o que seria válido para seu universo. Percebe-se, em todos esses casos, que um projeto transmídia tem seus produtos criados, ou organizados, de maneira a proporcionar um universo narrativo coerente. A própria Disney é um exemplo de empresa que desenvolveu personagens adorados e os fez circular por várias mídias, mas a maioria das histórias que criou antes de 2003 não possuíam efeitos cumulativos, assim não constituindo memórias de experiências vividas para seus personagens, exceto no caso das sequências de filmes e séries.

Outro grande exemplo é Matrix (1999-2003), inclusive pelo fato de ter sido a obra que inspirou Jenkins a desenvolver o conceito de narrativa transmídia. A 
trama foi apresentada em três filmes, curtas metragens animados, duas coleções de histórias em quadrinhos e alguns videogames.

Tendo acesso a uma mídia isolada era impossível compreender todo o universo de Matrix. Esse ponto acabou se constituindo em um problema nesse caso, ainda mais pelo fato dos filmes terem sido produzidos antes das redes sociais. Assim apenas os fãs mais devotos tomaram conhecimento e acessaram todos os seus produtos, sendo, então, só desse modo, capazes compreender toda a narrativa da saga. A maior parte das pessoas não sabia que precisava ver mais que a trilogia para ter uma experiência completa. Talvez isso tivesse funcionado melhor se o público já estivesse habituado com o processo de busca de informações das narrativas transmidiáticas. Faltaram ganchos explícitos que levassem o público de uma mídia à outra.

Frank Rose considera que Matrix desapontou porque para o consumidor normal ele pediu demais e para os mais engajados ele entregou de menos: enquanto a saga crescia em complexidade, pontos importantes da história não eram desenvolvidos nos filmes, que captavam a maior parta da audiência, mas apenas nas outras mídias, que só chegavam aos fãs mais dedicados. (ROSE, 2012)

Ainda hoje percebe-se que a maior parte das pessoas não vai circular por todas as plataformas e, por isso, a forma de pensar as narrativas transmidiáticas começou a se voltar mais para o conceito de nave mãe (mother ship). Nesse caso, há uma plataforma principal que revela tudo o que é indispensável para a compreensão da obra, e as demais mídias oferecem conteúdo adicional, que de alguma maneira aprofundam a experiência narrativa, mas sem comprometer o entendimento do todo.

Inicialmente Matrix seria uma trilogia, mas tudo mudou quando seus criadores, os irmãos Wachowski (atualmente mulheres trans, portanto irmãs), viajaram para o Japão para o lançamento do primeiro filme. Lá entraram em contato com o media mix japonês, que consistia em uma estratégia de venda casada de produtos.

Segundo Marc Steinberg, desde o início do anime, em 1963, o media mix foi central para sua existência. As produtoras de TV não estavam dispostas a pagar por um anime o seu custo de produção. Tezuka Osamu teve que vender Astro Boy 
por menos do que valia e, como forma de recuperar o investimento, se ancorou no licenciamento de produtos dos personagens, o que deu resultado. Seguindo esse exemplo, a produção de animes se apoiou nas vendas de outros produtos, como brinquedos, quadrinhos e videogames. O autor considera que, em troca, o anime pode levar um fã que não leria um quadrinho ou jogaria videogame a desbravar esse território, expandindo a base de fãs, e também o ciclo financeiro, fortemente entrelaçados. Essa prática tornou-se mainstream no Japão. Steinberg sublinha a ecologia de mídia no Japão como central para a conceptualização da narrativa transmídia, pois a concepção de um universo expansível, ao qual a audiência pudesse acessar a partir de diferentes plataformas, foi desenvolvida no Japão por editores e produtores de mídia, como Kadokawa Tsugyhiko, que viam cada mídia como parte de um todo e deixavam espaços nas narrativas para serem preenchidos pelos fãs. (JENKINS, 2013)

Havia as experiências de media mix que replicavam conteúdo pelas mídias, mas havia também outras que poderiam ser consideradas transmídia. O desenvolvimento da arte de contar histórias deixou de ser focado em um meio específico, para ser pensado tendo em vista um mundo onde uma série de narrativas fluem através de várias mídias. É comum que entre os primeiros produtores transmídia do ocidente estivessem fãs de anime e manga. Mas Marc argumenta que, por sua vez, essa mudança na forma das narrativas orientais foi influenciada pelos jogos de mesa de RPGs (table top role playing games) ocidentais, como Dungeons \& Dragons, que originaram a série de livros Dragonlance, onde, em um mundo préexistente, poderiam ser desenvolvidos muitos trabalhos. Mas chama atenção que o media mix nem sempre está relacionado à narrativa. Contar histórias através do media mix é uma das opções. A Hello Kitty, por exemplo é uma personagem de grande sucesso que não foi desenvolvida baseada em uma história. (MARC apud JENKINS, 2013)

A participação dos fãs teve uma influência muito maior na história do anime do que na dos quadrinhos nos EUA. Ian Condry cita o caso da série do robô gigante Gundam, que estreou em 1979 e no início tinha pouca audiência e baixa venda de brinquedos. Aos poucos, as atividades dos fãs da série foram crescendo e começaram a construir enciclopédias e linhas do tempo, estendendo esse universo ficcional. Os produtores de Gundam não se opuseram a essas criações não 
autorizadas, aproveitaram o momento para voltar a veicular a série, que acabou por se tornar umas das mais longas e bem-sucedidas de todos os tempos. (IAN apud JENKINS, 2013)

Dito tudo isso, é inegável a contribuição Matrix para o desenvolvimento de narrativas transmidiáticas no ocidente.

Jenkins considera que as narrativas transmídias se tornaram comercialmente atraentes que quando houve um alinhamento de três fatores: da convergência dos meios, da cultura participativa e da inteligência coletiva. $O$ autor considera que esses são os três pilares da Cultura da Convergência, que corresponde ao momento histórico iniciado com a web 2.0 e que perdura até hoje. (JENKINS, 2009)

\section{Convergência dos meios}

Os grandes conglomerados têm uma organização horizontal, atuando em diferentes setores da economia criativa, tais como televisivo, editorial, internet, e, com isso, possuem interesse de que seus produtos se expandam pelas diferentes plataformas de mídia, o que Jenkins chamou de sinergia. Isso era mais complicado quando cada setor pertencia a uma empresa diferente. Quando uma mesma empresa detém tantos segmentos, quanto melhor for pensado um produto para que ele possa se expandir por várias mídias, maior a probabilidade de ganhos econômicos. (JENKINS, 2007)

Pensando nesse cenário, em que expandir-se para outras mídias torna-se quase um imperativo econômico, o pesquisador argumenta que uma vez que as experiências de entretenimento serão realizadas através de múltiplas plataformas, usar a transmídia pode ser uma forma interessante para expandir e enriquecer a experiência de consumo dessas histórias. (JENKINS, 2010)

\section{Cultura participativa}

É a cultura em que fãs e outros consumidores são motivados a participar ativamente da criação e da circulação de novos conteúdos. Essa motivação pode ou não vir a convite dos produtores. As formas de engajamento do público são moldadas pelos protocolos sociais e culturais, e não pela tecnologia em si. É claro 
que a tecnologia, como os dispositivos de redes sociais e o conteúdo digital, que transita facilmente entre plataformas de mídia, facilitam o compartilhamento de conteúdo e a postagem de comentários. Assim podemos dizer que a tecnologia que temos hoje favorece a cultura participativa, em termos de facilidade, agilidade e até de proporção, pois nosso alcance consegue ser mais global, mas a participação não é uma novidade. Ela sempre ocorreu, por exemplo, nas páginas de cartas das revistas, mas havia uma maior mediação entre autores e fãs, além de limitação espacial (o espaço da página determinava a quantidade de cartas presentes). O formato da web, a partir da 2.0, contribuiu para a quebra de algumas barreiras de mediação: hoje é muito mais fácil um fã entrar em contato direto com um produtor através das redes sociais e praticamente não há limite de postagens.

\section{Inteligência coletiva}

É um termo cunhado por Pierre Levy, que se refere às novas estruturas sociais que permitem a produção e circulação de conhecimento em uma sociedade em rede, onde participantes compartilham informações e fazem uso das expertises uns dos outros, no trabalho conjunto para a resolução de problemas.

Jenkins diz que, por haver mais informação sobre cada assunto do que podemos guardar na memória, somos incentivados a conversar sobre eles. Essas conversas acabam movimentando o mercado de mídias. Por uma questão de socialização é importante que uma pessoa esteja minimamente atualizada com aquilo que está sendo falando, logo muitos conteúdos midiáticos são vistos por seu valor de social currency (termo derivado do capital social de Pierre Bourdieu, para ambos o valor advém das participações sociais). Para os produtores, acaba sendo mais que nunca relevante que seus produtos sejam comentados e debatidos.

Essa quantidade tão grande de informações, que torna quase impossível que uma única pessoa domine todo um conteúdo, já foi nomeada por alguns pesquisadores, como Umberto Eco e Janet Murray, como conhecimento enciclopédico.

Uma boa frase para sintetizar o consumo de informação na era da inteligência coletiva é: cada um sabe uma parte e quando juntamos as partes de cada 
um, juntos podemos saber mais. Corresponde a um paradigma de que compartilhando conhecimento todos saem ganhando.

Jenkins pensa a convergência como uma questão cultural e não tecnológica. Considera que na Cultura da Convergência, os consumidores são incentivados a procurar novas informações e fazer conexões em meio a conteúdos de mídia dispersos. Defende que os consumidores vão a "quase qualquer parte em busca das experiências de entretenimento que desejam.” (JENKINS, 2009, p. 29)

As características propostas por Jenkins como próprias às narrativas transmidiáticas incluem espalhar conteúdo vs. ir mais fundo na história; continuidade vs. multiplicidade; imersão vs. extratabilidade; construção de universo; serialidade; subjetividade e performance (criar um conteúdo interessante o suficiente para gerar engajamento e oferecer oportunidades para isso).

\section{1 - Spreadability vs. Drillability (Espalhar vs. Cavar fundo)}

Spreadability é a capacidade que um público tem de se engajar na ativa circulação de um conteúdo de mídia através de suas redes sociais (compartilhar), o que pode incluir desde uma ação offline, por exemplo, a indicação para os amigos de uma nova série em uma conversa de bar, ou até uma ação online, como publicar no status do facebook o conteúdo que curtiu ou mandar links para outros. A própria estrutura multiplataforma já realiza o espalhamento do conteúdo em várias mídias, podendo atrair seu público em diferentes momentos.

Drillability representa a forma com que um produto de mídia encoraja a audiência a ir mais fundo naquela história, sair da superfície em busca de saber mais sobre determinado universo. Apesar do vs. Jenkins não pensa esses conceitos como opostos e acredita que possam estar presentes em uma mesma experiência midiática.

\section{2 - Continuity vs. Multiplicity (Continuidade vs. Multiplicidade)}

A continuidade enfatiza a coerência: que todos os novos conteúdos que forem agregados a uma história respeitem o que veio antes. 
A multiplicidade seria ter versões alternativa de uma mesma história. Como o caso do Homem Aranha: há o Peter Parker que conhecemos e as histórias do Homem Aranha que se desenvolvem na Índia, onde o personagem atende até por um nome diferente, comum a essa cultura.

\section{3 - Immersion vs. Extractability (Imersão vs. Extratabilidade)}

Ambos os conceitos estão relacionados com a possibilidade do consumidor se engajar com o universo narrativo. O primeiro, a partir da imersão no universo, que pode ser no sentido figurado, no caso do público sentir que está imerso naquele mundo, ao ver em suas redes sociais postagens de seus personagens junto às de seus amigos ou receber e-mails da empresa da série; mas também no sentido literal, ao frequentar parques temáticos ou participar de uma experiência de realidade virtual. O segundo, apropriando-se de algo daquele universo para levar ao seu mundo, como no caso dos bonecos dos personagens ou roupas e adereços para Cosplay. $\mathrm{Na}$ imersão, o consumidor entra no universo da história e na extratabilidade, ele leva algo da história para o seu cotidiano. Assim, segundo a lógica de Jenkins a cerveja amanteigada e os sapos de chocolate de Harry Potter entrariam no princípio de extratabilidade.

\section{4 - Worldbuilding (Construção de universos)}

Para uma narrativa conseguir se expandir por várias mídias de forma coerente, é necessário um universo detalhado, de forma a ter conteúdo suficiente para isso. Uma analogia que ajuda a entender esse conceito é pensar em cada mídia como uma janela que ajuda a conhecer algo sobre o universo narrativo. Quanto mais personagens e acontecimentos se entrelaçarem, mais complexas as relações.

O escritor L. Frank Baum, criador do universo de Oz, pensava em si como um geógrafo do imaginário. Este ato de pensar o espaço da história como uma geografia ficcional, um universo, inclui também pensar nas relações culturais que se desenvolvem nesse local, a forma como seus habitantes se relacionam uns com os outros, se vestem, se comunicam, suas leis, rituais, e etc. 


\section{5 - Seriality (Serialidade)}

A serialidade implica que o desdobramento de uma história ocorra no decorrer de uma temporalidade, tipicamente através de um processo que o autor chama de chunking, que seria uma partilha da informação de uma história em pedaços e do processo de dispersão desses pedaços de forma conectada, tendo como ponto central a criação do gancho narrativo (story hook ou cliffhanger), o qual motiva o consumidor a seguir adiante para saber mais sobre aquela história. (JENKINS, 2011b) Nas narrativas transmidiáticas os ganchos devem levar os fãs também para outras mídias. Historicamente a serialidade ocorria no mesmo texto. Essa característica, como vimos, já fazia parte da literatura do século XIX e também está presente nas séries de TV.

\section{6 - Subjectivity (Subjetividade)}

A subjetividade é a possibilidade de demonstrar diferentes pontos de vista em uma mesma história, abrindo outros espaços para destacar personagens que em outro meio são secundários. Esse é o ponto mais relevante para essa tese.

\section{7 - Performance}

Jenkins divide a performance em dois conceitos: atratores culturais (cultural attractors), que toma emprestado de Pierre Levy, e ativadores culturais (cultural activators). O primeiro representa o conteúdo que, por ser interessante, acaba atraindo pessoas a participarem daquele universo. Os ativadores culturais oferecem a essas comunidades de pessoas com interesses comuns, coisas para fazerem juntas, atividades como a resolução de enigmas, por exemplo, e proporcionam trocas de conhecimentos.

Em resumo, a narrativa transmidiática é uma narrativa serializada, mas diferentemente de outros tipos de narrativas seriadas, sua história se desdobra em diferentes plataformas, podendo usar mídias tais como livros, programas de TV, filmes, canais de youtube, redes sociais, eventos ao vivo, jogos, peças de teatro, o que mais fizer sentido para a narrativa que se deseja contar. 
No caso de The Lizzie Bennet Diaries (The LBD) (2012), sua produtora, Pemberley Digital, criou uma obra atualizada e adaptada do romance Orgulho e Preconceito, no formato transmídia. A narrativa partiu, desse modo, de uma história única, com começo, meio e fim, que foi fragmentada em diferentes plataformas: youtube, twitter, sites e tumblrs.

A plataforma principal é o vlog de Lizzie, em que a protagonista conta grande parte da história como um diário de vídeo online. Convém destacar que a história narrada é o ponto de vista de Lizzie e esta representa o preconceito, presente no título do romance, enquanto o seu (futuro) par romântico, William Darcy, representa o orgulho. Assim, seu olhar sofre um viés, que é relativizado pela presença das outras mídias, onde os outros personagens podem falar de si.

Quem só assiste o vlog da Lizzie recebe todo o conteúdo relevante para entender a trama narrativa, mas quem acompanha as outras mídias têm uma experiência mais aprofundada, pois além da questão do viés, Lizzie também não tem acesso a tudo que acontece.

Ou seja, ela segue o modelo nave-mãe. O produtor de The $L B D$, Bernie $\mathrm{Su}$, considera essa forma de fazer transmídia como capaz de unir, em um mesmo produto, aqueles que querem ter uma experiência de sofá (lean back experience) e aqueles que querer caçar informações por todas as plataformas. Os mais ativos são recompensados com mais detalhes e histórias paralelas que complementam a narrativa principal. Bernie Su revela que metade da audiência assistia apenas os vídeos de Lizzie e a outra metade assistia também os vídeos de Lydia. Apenas 25\% da audiência seguia os personagens nas redes sociais, indo atrás de uma experiência mais aprofundada. Concluiu, então, que não era possível esperar que todos fossem circular entre plataformas e percebeu que a história sempre precisa vir em primeiro lugar, que o realismo imersivo, ainda que importante, tem que estar em segundo plano (SU, 2013b).

No caso de Skam, a série também constitui uma experiência completa e é ainda mais independente que o vlog de Lizzie para a compreensão da narrativa. As redes sociais, no entanto, oferecem conteúdo adicional e permitem um maior envolvimento com os personagens. 
Toda a intriga deve estar estruturada de forma a estimular a visita do espectador às diferentes mídias. O desafio é conseguir manter conteúdo interessante em todos os meios. $\mathrm{O}$ que ocorre algumas vezes em experiências malsucedidas é que a vontade de fazer transmídia é colocada acima do mais importante, que é contar uma história.

Nem todas as franquias transmídia se desenvolvem nesse modelo nave-mãe. Algumas, ao contrário, tornam importante que se consuma todo o conteúdo presente em diferentes mídias para que, como um quebra-cabeça, possa se entender a história ou participar de um desafio. Esse modo de projeto funciona mais com produtos de nicho, que possuem um público suficientemente engajado a ponto de circular por todas as plataformas.

Todos os personagens que compõem a série The $L B D$ foram modernizados, mas o enredo segue a obra Orgulho e Preconceito de Jane Austen (AUSTEN, 1982). Procurei observar como, nessa adaptação transmídia, a obra original foi revisitada.

\subsection{O tempo como fator que influencia a adaptação}

Trazendo a série para a atualidade, foi preciso adaptar seu conteúdo de maneira que ele pudesse fazer sentido em uma realidade completamente distinta à do século XIX, momento em que a obra Orgulho e preconceito foi escrita. As questões humanas se mantêm, mas a conjuntura se transformou. Principalmente no que diz respeito à situação de uma família composta só por mulheres que não poderiam herdar nem sua própria propriedade quando o patriarca da família falecesse. $\mathrm{Na}$ época, as mulheres não podiam herdar propriedades, que passavam para o parente mais próximo do sexo masculino, no caso Mr. Collins. A família Bennet tinha recursos financeiros restritos, cinco filhas e nenhum herdeiro. A salvação dessas mulheres era o casamento. Essa era a forma de realização pessoal e garantia de uma vida confortável.

Por esse motivo, a matriarca da família tentava desesperadamente casar suas filhas, para que pudessem ter uma vida digna e não depender da bondade do parente para ter um lar no futuro. Ela se preocupava muito com as atitudes de sua filha mais nova, Lygia, que não eram consideradas nada respeitáveis, e ainda poderiam 
colocar em risco a reputação de todas as suas irmãs, o que lhes trariam menos oportunidades matrimoniais e lhes fecharia as portas para o convívio social.

Segundo Ismail Xavier, pesquisador brasileiro focado no estudo das adaptações, os deslocamentos temporais ou geográficos acarretam inevitáveis transformações de significados, assim é impossível apresentar os mesmos sentidos ao apenas reproduzir os mesmos conteúdos em culturas distintas. Uma adaptação dialoga não só com a obra que adapta, mas também com seu próprio contexto, atualizando sua pauta. Ismael sugere olhar para a obra inspirada como um ponto de partida e não um ponto de chegada (XAVIER, 2003).

Assim fez a Pemberley Digital em sua adaptação The Lizzie Bennet Diaries. A matriarca da família segue obcecada por casar suas filhas, mas, para a Lizzie de hoje, esse comportamento pode ser satirizado em seus vídeos como exagerado. Essa questão não tem mais como ter o peso que tinha na narrativa original, por isso muitos conflitos ligados a casamento foram substituídas por aspirações profissionais, sendo o trabalho o caminho atual para se garantir o sustento e esfera importante da satisfação pessoal, sem deixar de lado, é claro, o amor.

Entre os aspectos mais formais, estão o fato da família Bennet passar a ter três filhas (Kitty transformou-se na gata de Lygia e Mary, numa prima) e a mudança de distância da vizinhança, no caso da propriedade de Bing Lee, que não podia ser mais de $3 \mathrm{~km}$, como uma propriedade rural britânica do início do século XIX. Outras mudanças culturais acabaram por alterar o destino de alguns personagens. As mulheres, de uma forma geral, ganharam mais poder de ação na resolução de problemas. Lydia não teve que se casar com Wickhan por ter dormido com ele, e sua humilhação não foi esse ato em si, mas sim ele ter anunciado que publicaria um vídeo dela na internet. No livro, Lydia precisa se casar com Wickhan, não só por ela, mas pela reputação e futuro da família, ainda que todos soubessem que ele era uma péssima pessoa. Na série transmídia, William Darcy, que tinha assuntos passados a tratar com Wickhan e já estava totalmente apaixonado por Lizzie, conseguiu evitar que o vídeo entrasse no ar, ao invés de obrigá-lo a se casar com Lydia. Na adaptação, Wickhan é capitão de um time de waterpolo e não um oficial do exército. A personagem de Mary, apesar de passar de irmã para prima, teve seu arco de evolução do personagem mais bem desenvolvido e o fato dos fãs terem gostado muito dela fez com que seu papel fosse ampliado. 
Ambos Mr. Collins falam demais, e de forma gratuitamente rebuscada. No original, ele é um clérigo protestante que propõe Lizzie em casamento. $\mathrm{Na}$ adaptação atualizada, a proposta passou a ser uma oferta de trabalho, que Lizzie recusou, e que foi aceita por sua melhor amiga Charlotte, da mesma forma como ocorre no livro. Charlotte também é uma personagem mais importante na série, inclusive ajudando Lizzie com a edição dos diários.

Lizzie vai trabalhar na Pemberley Digital, que é a empresa da família Darcy, e não mais visitar a propriedade rural dos tios, próxima à casa dos Darcy, chamada Pemberley, não por acaso o mesmo nome da produtora da série.

\subsection{Orgulho e Preconceito no formato transmídia}

Como já foi dito, a história é contada a partir dos diários online de Lizzie, no youtube, e complementada pelo twitter de vários personagens, tumblrs, diário online de Lydia (presente no canal de Lydia e lançados já na metade da experiência), blog de moda de Jane, site da empresa de Mr. Colins e vídeos-teste da nova plataforma de vídeo da fictícia Pemberley Digital, operada por Gigi Darcy, irmã de William Darcy, entre outros.

Os vídeos de Lizzie, além do seu ponto de vista, algumas vezes dão lugar a depoimentos de sua amiga Charlotte Lu e de suas irmãs, a doce Jane e a doidinha Lydia. Todas possuem twitters e algumas tumblrs. Outros personagens, como Bing Lee, sua irmã Caroline Lee e seu amigo William Darcy, também usam o twitter desde o princípio. É interessante que os tweets mostram o ponto de vista dos personagens que não estão aparecendo no $v \log$. (Bing Lee, sua irmã Caroline Lee e seu amigo William Darcy).

Lizzie é a "dona" do vlog e Charlotte sua editora. Algumas vezes as irmãs a interrompem e, outras vezes, elas são chamadas por Lizzie, sobretudo para ajudar nas encenações caricatas que usa para contar seu lado da história.

The $L B D$ era filmado 4 ou 6 semanas em avanço para ser adaptável, mas Bernie observou que as críticas precisavam ser levadas em conta, apesar de não necessariamente acatadas: a personagem de Lizzie foi criticada por ser muito dura nos comentários, mas atenuar isso, ou não, era um ponto que necessitava de 
reflexão, pois tinha a ver com seu viés preconceituoso e, sendo uma vlogger, era natural que imprimisse sua opinião (ROMANO, 2012a).

O estilo de um vlog é o da intimidade. Janet Murray comenta que o computador é capaz de criar um espaço que é público, mas que também aparenta ser privado e íntimo, a tal ponto, que existem pessoas que compartilham online histórias pessoais que não contam nem para seus amigos (MURRAY, 1999).

O vlog é contado em primeira pessoa e, ainda que tenhamos a participação de outros personagens, a voz mais forte é a de sua "dona", Lizzie: trata-se de um diário ficcional.

No livro Tempo passado, a autora Beatriz Sarlo cita Arendt (ARENDT apud SARLO, 2007), que apontou que, apesar do testemunho ser passível de desconfiança, ele é, ao mesmo tempo, uma instituição da sociedade, tendo a ver com a esfera jurídica e com um laço social de confiança. Ela acrescenta que, quanto mais detalhes tem o testemunho, mais veracidade a narrativa parecerá ter. A falta de distanciamento e a abordagem íntima em primeira pessoa nos passam uma impressão de sinceridade.

Lizzie tem ciência da subjetividade de sua narrativa: chega a comentar, em um de seus últimos posts no vlog, que as coisas que relata são um recorte da realidade sob a sua perspectiva, sua opinião pessoal.

Vera Figueiredo descreve, como um ato comum no romance modernista, atitudes semelhantes à de Lizzie, em que frequentemente o narrador se autoparodia, como se estivesse a se justificar, pedindo desculpas por ter narrado algo, relativizando certezas e multiplicando possíveis pontos de vista (FIGUEIREDO, 2010).

Em uma mesma mídia, como no caso do vlog de Lizzie, é possível ter mais de uma voz. Por exemplo, quando Lizzie, ao lado de sua irmã Jane, narra fatos ocorridos em uma festa entre ela e William Darcy ou entre a irmã e Bing Lee, Jane vai relativizando o testemunho de Lizzie através de suas caretas e comentários.

Quando sua irmã mais nova Lydia, chateada com ela, resolve lançar seu próprio $v \log$, passamos a ter acesso a mais de uma visão sobre o mesmo caso. 
A série levanta questões contemporâneas: quando Jane comenta que Lizzie e Lydia são muito parecidas, surpreendendo Lizzie com a comparação, ela explica que ambas passam a vida falando com todo mundo online, mas não uma com a outra.

Por ter a possibilidade de oferecer uma pluralidade de vozes, a transmídia pode relativizar a verdade e criar intrigas, a partir de testemunhos contraditórios, ou porque alguém está mentindo ou enganado sobre determinada situação, ou porque refletem visões de mundo de diferentes personagens. Como vimos, o princípio da subjetividade está entre as sete características-chave da narrativa transmídia, de Henry Jenkins.

É curioso ver como as pessoas "compram" a realidade das narrativas transmidiáticas de uma forma natural. No teatro infantil, as crianças reagem ao que assistem: gritam, aconselham os personagens e avisam que o malvado está surgindo por trás. É algo natural para elas, mas, conforme vão crescendo, deixam de se comportar assim. Aprendem que aquilo é ficção, sabem que no caso da TV e do cinema o personagem não vai ouvi-las, ainda que, às vezes, não hesitem em fazer algum comentário em voz alta, principalmente em filmes de suspense e thriller, que deixam os nervos à flor da pele. Entendem que, em um teatro não interativo, não têm influência na narrativa. Mas, no caso das ficções participativas, ou que passam pelo menos essa sensação de influência, as pessoas são capazes de se relacionar com naturalidade com os personagens em seus perfis nas redes sociais. Em Perplex City, quando a personagem Anna foi encontrada morta, uma profusão de cartas foi enviada aos demais personagens para consolá-los e origamis foram mandados para a sede da produtora. Parece o resgaste de uma relação de faz de conta mais visceral.

No episódio 16, Charlotte mostrou-se muito pessimista e desanimada com a vida e os próprios viewers, preocupados, começam a perguntar via twitter o que ela tinha e se estava melhor.

No tumblr, Jane, que trabalha com moda, expõe seus lookbooks, abrindo espaço para destacar patrocínios e apoios, como as roupas usadas pelas personagens. 
No twitter, os fãs também se comunicam com Lizzie, perguntando sobre acontecimentos da história ou fazendo comentários sobre temas com os quais se identificam.

Lizzie faz um episódio especial de perguntas e respostas, no qual responde o que lhe perguntam no twitter e facebook. Mr. Collins, que está ao seu lado, quando ela apresenta para audiência o propósito do episódio, comenta: "humm, interatividade, claro! Uma forma tão progressista e sagaz de se conectar com a sua audiência. De certa forma, você está fornecendo um canal para...” Ela interrompe a fala, que de outra forma seria muito longa, mas esse extrato da frase já cumpre seu papel de fazer um autocomentário sobre a série.

Nesse mesmo episódio especial, uma jovem que havia participado do projeto Better Living, da empresa fictícia de Mr. Collins, lhe faz uma pergunta. Ele aproveita a deixa para anunciar que o link do vídeo dessa jovem está no texto de descrição do episódio, chamando atenção para que os fãs conheçam o projeto, do qual também podem participar enviando vídeos curtos demonstrando suas habilidades para passar instruções de forma simples. Mr. Collins também usou seu twitter para divulgar o projeto, o qual constituiu uma abertura para participação em um campo totalmente a parte do desenrolar narrativo, mas que foi capaz de engajar alguns fãs, aumentando seus laços com a série.

Depois do término inesperado e sem sentido do relacionamento com Bing Lee, Jane vai para Nova York para trabalhar com produção de moda, com isso saindo dos vídeos de Lizzie. Nesse momento, Lydia, que já tem o seu próprio vlog, vai passar uns dias com Jane, de modo que o contato dos fãs com ela é mantido por vídeo.

Seguindo a técnica de levantar questões para despertar a curiosidade do público, alguns eventos ficam um bom tempo em aberto, como a mudança inesperada da família Lee, que deixa a cidade. Bing vai embora sem nem mesmo se despedir de sua namorada Jane, e Caroline, que nesse momento se dizia amiga de Lizzie e até já sabia da existência dos diários online, passa um tempo sem dar qualquer notícia. Outro mistério é a carta que Lizzie recebe de Darcy revelando fatos que não podiam ser ditos em público. 
Lee aparece em um dos vídeos de Lizzie no começo da série e Darcy só três meses depois, já no final da série. No entanto, foi sempre possível acompanhá-los no twitter.

No episódio 75, de natal, Lizzie pede para os fãs falarem sobre suas formas de celebrar essa tradição ou qualquer outra semelhante, constituindo uma outra participação que não tem qualquer relação com o enredo.

Gigi Darcy, a irmã de William Darcy, que só aparece no twitter quando a série já estava no episódio 75, começa a rever os vídeos antigos, retweetando-os junto a comentários, o que foi uma estratégia interessante para trazer público novo. Essa personagem só aparece nos vídeos quando Lizzie vai trabalhar na Pemberley Digital, empresa dos Darcy, e registra seu cotidiano de trabalho. Gigi já sabe de sua história e do amor que o irmão tem por Lizzie, mas mantém-se discreta.

No final da narrativa, Gigi tem um papel fundamental, pois, a partir de suas mensagens de vídeo para Darcy e outro parceiro, na plataforma Domino, ficamos sabendo da investida de Darcy para salvar a reputação de Lydia.

No vlog de Lydia são desenvolvidas tanto histórias relevantes para a trama, como sua fuga com Wickhan, quanto histórias adicionais, como as relacionadas à sua prima Mary.

Mas, em geral, tudo o que é indispensável à história aparecerá, em algum momento, no vlog de Lizzie, ainda que de forma atrasada em relação às outras mídias. Nesses casos, os fatos aparecem com o mecanismo de recapitulação, narração dos fatos passados. Assim, as pessoas que não mudam de meio conseguem ter acesso a toda a narrativa, mas quem circula sabe antes e, algumas vezes, de forma até mais emocionante sobre alguns eventos.

Após o final da experiência, um ano depois, foram publicados dois vídeos bônus, um com Lizzie e outro com Lizzie e Darcy, respondendo perguntas como se fizessem parte de um seminário sobre o tema hypermediation in new media. Lizzie, como colaboradora da Pemberley Digital, diz que sua empresa busca nos vídeos ponto de vista e paixão, que é importante que não se esteja gratuitamente querendo aparecer. E comenta que estavam publicando um livro diário secreto, onde havia uma cópia da carta de Darcy, obviamente despertando a curiosidade dos fãs. 
No livro em questão, The secret diary of Lizzie Bennet, é possível encontrar mais informações sobre o pensamento de Lizzie a respeito de cada episódio. Pelos comentários, os fãs parecem ter gostado do livro, mas esperavam que fosse mais profundo nos segredos da personagem. Uma leitora reclamou em seu blog que, na parte correspondente aos capítulos 60 e 98, o diálogo do vídeo foi transcrito em suas exatas palavras, sem nenhuma informação extra, o que reafirma que os fãs esperam encontrar conteúdo diferente em cada plataforma (O’CONNOR, 2014). A narrativa transmídia precisa oferecer compreensão aditiva. Toda mídia precisa contribuir com algo a mais para a história.

Foi lançado, também posteriormente, o livro The Epic Adventures of Lydia Bennet, mais um desdobramento da série The Lizzie Bennet Diaries, que continua a história da irmã caçula Lydia Bennet, incluindo reviravoltas para essa personagem e seus novos desafios, como a busca de uma carreira.

O facebook da série era uma mídia mais institucional: permitia saber tudo sobre a série e sobre os atores, além de acessar a loja online para comprar seus produtos. Como a história é disponibilizada gratuitamente, a loja é uma das formas de captação de recursos.

Apesar de The $L B D$ ser uma série cheia de capilaridades, eles ofereceram um desenvolvimento narrativo que segue uma linha do tempo. A estratégia conhecida como many-to-one linking pode distrair o leitor pela quantidade de links iguais, mas, por outro lado, tem a vantagem de diminuir as chances de que a informação se perca (LANDOW, 1997).

Para guiar a audiência, os produtores criaram um portal, como um meta-site com aparência de blog, onde estão organizados todos os links postados. Na homepage existiam as opções de acessar toda a experiência (onde é mostrada uma lista dos posts dos diários online, twitter e tumblr, organizados todos juntos pela data de postagem); ver apenas a coleção dos diários online; ou escolher uma mídia específica para visualizar, também organizada cronologicamente. Na barra lateral era possível ver as postagens, mês a mês, e nas categorias de sessões também havia acesso para behind the scenes, news e story (que mostrava os mesmos posts da experiência completa dispostos em um layout de textos e imagens), tumblrs (de 
todos os personagens), twitters (de todos os personagens) e vídeos. Os personagens ainda podiam ser seguidos diretamente nas redes sociais.

O portal facilita a vida dos fãs que não querem perder nada e dos que querem seguir a história de maneira mais fácil. Posteriormente, após o desenvolvimento de outras adaptações de clássicos para o formato transmídia, a Pemberley Digital juntou tudo o que estava no metasite da Lizzie no site da empresa, em uma aba própria, lado a lado com o mesmo modelo aplicado às outras produções.

Na narrativa hipertextual não existe uma única rota possível, logo as pessoas têm acesso a diferentes conteúdos e, sendo assim, sentem-se motivadas a falar umas com as outras, tanto para mostrar o que conseguiram descobrir, quanto para colher mais informações, podendo, dessa forma, entender melhor o cenário completo, a partir dessa inteligência coletiva. Isso encoraja o desenvolvimento de fóruns e wikis, especialmente quando há suspense envolvido.

Numa entrevista, Bernie Sue contou que, mesmo com todos os episódios e interações disponíveis, gratuitamente, no youtube e nas redes sociais, os fãs não paravam de perguntar se ao final da experiência poderiam comprar um DVD da série (ROMANO, 2012b). Este fato motivou a produção do DVD por crowdfunding, levantando os fundos através do site Kickstarter. Primeiramente, calcularam um orçamento para um DVD de seis horas de duração, mas, como alcançaram a meta em apenas um dia, decidiram ampliar o material. $\mathrm{O}$ sucesso da coleta foi tanto que conseguiram, não só fazer um DVD com mais elementos, mas também dar um bônus, para os atores e para a equipe, e produzir uma nova minissérie, Welcome to Sanditon, para preencher o espaço de tempo entre The Lizzie Bennet Diaries e a sua produção seguinte, Emma Approved. O projeto todo está detalhado no Kickstarter. ${ }^{35}$

O spin off Welcome to Sanditon também é uma adaptação de outro romance de Jane Austen, Sanditon, que não foi terminado. Ainda que esse romance não tenha nenhuma ligação com Orgulho e Preconceito, foi usada uma das personagens de The LBD como protagonista, Gigi Darcy. Emma Approved também contou com a participação de Caroline Lee.

\footnotetext{
${ }^{35}$ Informações disponíveis em: https://www.kickstarter.com/projects/pemberleydigital/the-lizziebennet-diaries-dvdand-more/posts/874414
} 
Bernie Su relata que um dos seus maiores desafios em The $L B D$ foi pensar em como integrar a participação, pois, quando são utilizadas mídias que abrem espaço para o diálogo, é preciso entrar nesse jogo de comunicação.

Sanditon parece ter sido o projeto escolhido com o objetivo de explorar a participação. Foram inteligentes em eleger uma personagem já querida como protagonista, chamando para a nova série um público já fiel, que buscava prolongar a experiência de The $L B D$.

Em uma entrevista para Motherboard, é possível notar o medo da participação, no caso de The $L B D$. Bernie fala sobre a dificuldade em responder perguntas, contando que, uma vez, um fã perguntou a Lizzie qual era sua cor preferida, coisa que parecia simples, mas não era, porque, se fosse respondido verde, por exemplo, e o fã identificasse nos vídeos que Lizzie usava sobretudo azul, poderia perguntar por que ela então só usava azul, o que poderia quebrar a história (EÖRDÖGH, 2014). Lidar com as interações pode ser um trabalho desafiante, mas, em casos como esse, um perfil bem detalhado de cada personagem pode resolver esse problema. Em uma série transmídia que estou desenvolvendo ${ }^{36}$, criamos uma planilha no google drive acessível a todos os envolvidos na criação da série, onde cada personagem ativo nas redes tem uma aba com seu nome. Se, a qualquer momento na interação com um fã, algum ator responder algo não pensado anteriormente, ele pode adicionar a informação à planilha, garantindo que ela não se perca, mantendo o pacto da suspensão da descrença.

Outra preocupação de Bernie Su era a de fazer a adaptação de uma obra canônica preservando seu enredo: "O cânone aqui são as pouco mais de nove horas de história, e interagindo com os fãs esse cânone pode ser quebrado, ou mesmo o final da história pode acabar sofrendo alterações" ${ }^{37}$. Talvez por isso escolheram o livro Sanditon, uma obra inacabada, para experimentar participação, pois não havia rumos a serem tomados, a fim que se chegasse a um desfecho pré-definido (EÖRDÖGH, 2014).

Alexandra Edwards, editora transmídia de The $L B D$, conta que seus fãs eram tão apaixonados que iam atrás de toda e qualquer coisa postada, sendo necessário,

\footnotetext{
${ }^{36}$ A série a qual me refiro se chama Desnorteadas: www.desnorteadas.com.br.

${ }^{37}$ Tradução da autora: The canon here is the nine-plus hours of story, and interacting with the fans can break canon, or even change the outcome of the story (EÖRDÖGH, 2014, n.p.).
} 
assim, oferecer informações apenas com o ritmo que eles fossem capazes de manter, pois acostumar os fãs com uma quantidade inviável de postagens teria como resultado a decepção (ROMANO, 2012b).

Com The $L B D$, os produtores tiveram algumas dificuldades quanto à separação do mundo real e ficcional. Se Lizzie postava seus vídeos online, como os outros personagens poderiam não ter conhecimento sobre eles? Essa pergunta fez com que os produtores ao realizar um novo projeto, Emma Approved, dividissem as interações entre in-world e out of the world. Assim, existiam vídeos que Emma fazia que eram destinados somente à sua análise pessoal e, portanto, não se propunham a estar online in-world, o que significa que, para a realidade ficcional, eles seriam mantidos em segredo, mas na nossa realidade, out of the world, seriam vistos online (SU, 2013a). As interações nas redes sociais sim, estavam também online no universo da série.

Os mecanismos de indexação estabelecidos no metasite também permitiram que as séries pudessem ser seguidas por aqueles que não assistiram a narrativa desde o início. Um dos problemas de seguir atrasadamente uma série transmídia é que a maioria das redes sociais (para não dizer todas), tem o seu conteúdo disposto a partir do mais novo para o mais antigo, sendo então praticamente impossível acompanhar uma rede, tentando ver a sequência narrativa sem ter spoiler. Quando as postagens são vistas como arquivos, a partir dos links do metasite, isso já é possível, mas claro que perdendo a experiência de ver a postagem do personagem entre as de seus amigos nas redes sociais.

Com poucas exceções, os conteúdos de The Lizzie Bennet Diaries nas diferentes plataformas são complementares e oferecem informação adicional: levantam algumas perguntas e estabelecem pequenos mistérios, a redundância é leve, servindo apenas como apoio à memória ou para situar o que ocorreu fora da plataforma principal.

O livro The secret diary of Lizzie Bennet foi criticado por ter dois capítulos com informação redundante, mostrando que esse não é o caminho que interessa aos fãs, os quais desejam ir mais fundo nas histórias que gostam, conhecendo melhor seus personagens, que precisam ser ricamente construídos, propiciando um alto 
grau de empatia, para, como resposta, gerar mais engajamento por parte da audiência.

O estudo do caso de The LBD, e de outras séries da Pemberley Digital, me permitiu pensar em estratégias para o desenvolvimento de minha própria série, Desnorteadas. Claro que quando passamos da teoria para a prática esbarramos em muitos desafios não planejados. Um exemplo disso, foi quando lançamos os perfis das nossas personagens no facebook. Já no primeiro dia, homens aleatórios assediaram as nossas personagens e não tivemos tempo para planejar como lidar com possíveis interações como essas. Tivemos que antecipar a data de lançamento do projeto, porque o mecanismo do facebook começou a indicar os perfis das personagens para nossos amigos reais, o que nos fez temer que eles pudessem denunciá-los como falsos, se não soubessem do que se tratava.

Outra questão em se usar redes sociais é que os mecanismos mudam o tempo todo e plataformas caem e crescem, logo precisamos estar sempre atentos para rever estratégias. Outra dificuldade encontrada para levar o público de uma mídia para outra é que nem todas permitem links.

Anteriormente, a maior parte dos projetos que poderiam ser incluídos na definição de transmídia que adotamos nessa tese eram do meio publicitário, sendo poucos os exemplos de ficção. Hoje já encontramos muito mais exemplos bemsucedidos de séries de ficção transmídia, como Skam, uma série norueguesa que se tornou um sucesso global, a ponto de ganhar adaptações em diferentes países.

A sedimentação do termo permite uma melhor comunicação, tanto no meio acadêmico, quanto no mercado, contribuindo, assim, para que se pensem projetos que trabalhem no âmbito do desdobramento narrativo.

É possível, usando o formato transmídia, criar um diferencial para um projeto, agregando mais engajamento e mais canais para identificação, ainda que tenhamos muitos desafios na prática. 


\subsection{Skam, a série local que se tornou global}

Skam é uma série transmídia produzida pela NRK, rede pública de TV norueguesa. Foi escrita e dirigida por Julie Andem e teve Mari Magnus como produtora de todo o seu conteúdo digital.

Suas quatro temporadas foram exibidas entre setembro de 2015 e junho de 2017. Tinha o claro objetivo de oferecer um conteúdo de interesse para os adolescentes noruegueses, que pouco ligavam para a TV, focando, em especial, nas garotas de 16 anos. A distribuição inicialmente se dava apenas no portal digital da NRK. Só quando se tornou um sucesso foi que a série entrou para a programação de grade do canal. Nem o canal, nem sua equipe de apenas oito pessoas, nem os atores, podiam imaginar o que estava por vir. (SÉRIE SERIES, 2016; MEDIAMORFOSIS TRANSMEDIA, 2017)

A pergunta que não quer calar é como essa série adolescente norueguesa conseguiu se tornar um sucesso mundial, sendo produzida em uma língua de difícil compreensão fora do mundo escandinavo e sem tradução oficial de legendas, nem ao menos para o inglês? E sem que houvesse qualquer campanha de marketing visando o exterior. Somando-se a isso, o portal da NRK P3, que exibia Skam, ainda foi bloqueado por geolocalização, por questões de direitos autorais das músicas.

Mesmo assim, foram se formando comunidades de fãs no mundo inteiro Europa, Estados Unidos, Brasil, China, Índia, Rússia - ávidos por ver a série e produzindo legendas não oficiais, wikis, compartilhando os episódios em pastas no google drive, em sites não oficiais, no facebook, ou onde mais conseguissem.

Segunda a produtora executiva do programa, Marianne Furevold, eles atingiram, em sua terra natal, um nível de reconhecimento de $98 \%$, semelhante ao da Coca-Cola. Durante muito tempo, não havia sequer um dia em que não houvesse uma reportagem no jornal ou em alguma revista sobre a série. (SÉRIE SERIES, 2016)

A Noruega é um país com 5,2 milhões de habitantes. Tendo em vista o público alvo de garotas de 16 anos, o potencial que tinham para alcance era de 30.000 pessoas. (MEDIAMORFOSIS TRANSMEDIA, 2017) Em junho de 2018, só o Portal Skam Brasil no facebook já tinha 88.079 membros, fora as 156.308 pessoas que curtiram sua fanpage e as 171.129 pessoas que a seguiam. 
O último episódio da segunda temporada de Skam foi trending topic global no twitter com a hashtag \#ThankYouSKAM. Através dela, os fãs de todo o mundo compartilharam histórias de como Skam impactou suas vidas. (MEDIAMORFOSIS TRANSMEDIA, 2017)

$\mathrm{Na}$ China, na plataforma weibo, rede social muito popular no país, \#skam alcançou 180.000.000 visualizações e o casal gay \#evak (shipagem dos nomes Evan e Isak) teve 50.841.000 visualizações. (MEDIAMORFOSIS TRANSMEDIA, 2017; TEDX TALKS. SKAM, 2017)

Até um quase incidente diplomático teve que ser contornado quando, por contas dos direitos autorais das músicas, Skam ficou restrito à Noruega. O ministro da cultura da Dinamarca entrou em contato com o ministro da cultura da Noruega para pedir a liberação para o país, por conta de seu grande público de fãs desconcertados, pois já haviam acompanhado duas temporadas. A Dinamarca fez, então, um acordo com a indústria fonográfica, para que fosse feita sua liberação. $\mathrm{O}$ mesmo ocorreu com a Suécia. (MEDIAMORFOSIS TRANSMEDIA, 2017)

A repercussão internacional de Skam se deu na aliança de um conteúdo capaz de dialogar e ser relevante para além do seu público alvo inicial, e nas possibilidades técnicas que os fãs dispõem hoje para compartilhar a série, ainda que nem sempre por vias legais.

O sucesso fez com que vários países fizessem acordos com a NRK para produzir uma adaptação da série. Entre os que já têm sua adaptação sendo exibida estão: Estados Unidos (Skam Austin), Alemanha (Druck), França, Itália, Espanha, Holanda e Belgica. E há rumores de que outros países estejam em negociação.

Mas afinal do que trata a série? Skam significa vergonha. A premissa da série é "todos que você conhece estão lutando uma batalha sobre a qual você não sabe nada".

Ela aborda, entre outros temas cotidianos da vida de jovens estudantes do ensino médio, os seguintes: redes sociais, imigração, homossexualidade, estupro, doenças alimentares, doenças da mente, religiosidade, relacionamentos amorosos, familiares e entre amigos.

O objetivo de levar os jovens para a TV não era uma tarefa fácil. A sensação que os adolescentes tinham era de que lá não havia nada para eles, o que, de fato, 
era a realidade. A NRK permitiu que a equipe de Skam se dedicasse alguns meses às pesquisas a fim de desenvolver temas que pudessem ser do interesse do público alvo. As concorrentes eram as séries de alto orçamento norte americanas como Game of Thrones, Breaking Bad e Modern Family; e as redes sociais, em especial, youtube, instagram, snapchat e facebook. (MEDIAMORFOSIS TRANSMEDIA, 2017)

Em apresentação e debate no evento Mediamorfosis Transmedia, que ocorreu na Argentina, as criadoras Julie Andem e Mari Magnus revelaram várias informações sobre o processo de criação da série. Por ser uma produção pequena, a alternativa que consideraram mais viável para se conectar com os jovens foi a de entregar algo mais local, que de fato correspondesse à realidade norueguesa e usaram as redes sociais como parte da série, tirando partido dessa possível concorrência também a seu favor. A identificação do público com os personagens foi então o objetivo a se alcançar.

Durante o período das pesquisas, ouviram muitos jovens nas escolas e centros de jovens, levando-os totalmente a sério e investiram horas em estudos de suas redes sociais, para entender melhor sua linguagem e senso de humor.

Para identificar suas necessidades e temas relevantes, fizeram uso do método NABC (Needs, Approach, Benefits, Competition).

A pesquisa é qualitativa e tenta destacar do público alguns representantes típicos para, assim, decalcar suas necessidades, seus complexos e sonhos.

De uma forma geral, perceberam que os jovens hoje estão sob muita pressão, eles querem ser perfeitos em tudo, das escolas às redes sociais, aos esportes. Seria possível fazer um programa que desse voz a essas pressões?

Indo por esse caminho, como benefício poderiam oferecer aos adolescentes ferramentas para rirem de si mesmos, para ironizar. Isso poderia ajudar para que, em lugar de se sentirem fracassados quando não conquistassem seus objetivos, pudessem rir disso e aliviar assim a tensão. (MEDIAMORFOSIS TRANSMEDIA, 2017) 
Definiram como missão:

Skam tem como objetivo ajudar garotas de 16 anos a trabalhar sua autoestima, desmantelando tabus, fazendo com que tenham consciência dos mecanismos das interações interpessoais, e mostrando para elas os benefícios de confrontar seus medos. (SÉRIE SERIES, 2016) ${ }^{38}$

Os personagens também surgiram da pesquisa. Conversando com uma garota muçulmana de 17 anos, identificaram uma necessidade que deveria ser atendida: as pessoas costumam ver garotas muçulmanas como vítimas de pressão e machismo, a garota queria ver representadas muçulmanas fortes e confiantes não só em si mesmas, mas também em sua religião. Daí surgiu a personagem Sana. Por conta da não familiaridade da roteirista com a experiência de ser uma garota muçulmana, foi a personagem que mais demandou pesquisa e, não por acaso, uma garota muçulmana foi escolhida para interpretar Sana, Iman Meskini. A atriz estava constantemente em diálogo com a roteirista e, na quarta temporada, em que foi protagonista, foi a única a ter a liberdade, em toda a série, para fazer anotações no roteiro. Mas os atores sempre estiveram atentos também para contribuir no processo, avisando sobre gírias usadas de maneira errada ou pedindo para editar postagens que soariam estranhas para o público de sua idade. (PORTAL SKAM. Q\&A, 2018)

Os países que adquiriram o direito para realizar as adaptações de Skam também foram incentivados a realizar suas próprias pesquisas com o público local, a fim de que entendessem sua própria realidade e não apenas copiassem a franquia. A única exigência foi que os dois primeiros episódios fossem semelhantes aos da série original, os demais seriam livres.

A versão americana, Skam Austin manteve como roteirista a autora de Skam original, Julie Andem.

\subsection{O formato transmídia em Skam}

A série Skam era composta por clipes de cenas que eram exibidos durante a semana e que juntos formavam um episódio de websérie na sexta-feira (também

\footnotetext{
${ }^{38}$ Livre tradução de: Skam aims to help 16-year-old girls, strengthen their self-esteems through dismantling taboos, making them aware of interpersonal mechanisms, and showing they the benefits of confronting their fears. (SÉRIE SERIES, 2016)
} 
exibido posteriormente na TV); por capturas de telas de mensagens de texto, whatsapp e facebook messenger, que eram postadas no portal da série; e pelas interações dos personagens em suas redes sociais. Era possível acompanhar a vida fictícia dos personagens através de seus perfis no facebook, instagram e snapchat.

Os clipes de cenas, que variavam de 1 a 20 minutos, eram exibidos como em tempo real para a narrativa. Isso significava que se uma festa acontecesse às 21 h45 de sexta na série, o clipe da festa era exibido às 21 h45 de sexta.

Não havia aviso prévio de quando um conteúdo seria publicado, o que fazia com que o público que desejava saber tudo em primeira mão estivesse sempre visitando o portal. Mas sabiam sempre que, ao final da semana, o episódio completo poderia ser visto on demand na internet ou na grade de programação da NRK.

Na realidade, apenas $2 \%$ do público assistia a série na TV convencional, os 98\% restantes assistiam via streaming. (MEDIAMORFOSIS TRANSMEDIA, 2017)

Usar o formato de narrativa transmídia não é algo novo para uma série. Como vimos, algumas webséries, como The Lizzie Bennet Diaries e outras produções da Pemberley Digital, já optaram por essa forma para contar suas histórias anos antes. No entanto, Skam radicalizou no formato, não só pela quantidade de personagens com redes sociais para interagir, quanto pela decisão de postar no tempo real da narrativa.

Tendo sido produzida inicialmente para web, os episódios da série não tinham o mesmo tamanho, variando de 14 minutos a 1 hora. Por sua forma de distribuição digital, o tempo dos episódios não precisava ser uniforme e toda a linha de produção foi pensada tendo isso em consideração. Quando o canal quis incluir Skam em sua grade, a roteirista e diretora disse que não tinha como mudar essa forma e havia ainda mais um agravante: eles só costumavam saber horas antes, no próprio dia de exibição, o tamanho exato dos episódios. Por conta do sucesso da série, a emissora aceitou mesmo assim, então tiveram que arrumar programas e outras formas para preencher o espaço variável na grade. (MEDIAMORFOSIS TRANSMEDIA, 2017) 
O processo de trabalho funcionava da seguinte forma:

$\mathrm{O}$ roteiro era escrito uma ou duas semanas antes da gravação. Então a roteirista, Julie, sentava-se com a produtora de conteúdo digital, Mari, para pensar qual seria o conteúdo a ser veiculado nas redes sociais junto ao episódio. Nos dois anos de exibição de Skam, Julie e Mari trabalharam 24 horas por 7. Mari era a responsável por manter todos os 17 - 19 personagens ativos nas redes sociais, pois fazia todas as postagens. Chegou a ter 20 cartões de memória em diferentes celulares para fazer as interações entre as contas, sem precisar fazer login e logout toda vez. Para postar, tinha que pensar no que cada personagem estaria fazendo fora do momento em que estava em cena. Ficava atenta em eventos que ocorressem na vida real que pudessem ter a ver com algum personagem. Tinha que estar conectada o tempo todo para poder "viver" todos esses papéis. Cada temporada, com, em média, 12 episódios, mobilizou os produtores por 22 semanas. Cada episódio exigia 1 dia e meio de filmagem e 5 dias de edição. O investimento para as duas primeiras temporadas foi de 1 milhão de euros. (MEDIAMORFOSIS TRANSMEDIA, 2017) (PORTAL SKAM. Q\&A, 2018)

Em um artigo de Edvin Tedebring, focado na análise das interações dos personagens nas redes sociais a partir de seus gráficos, pude perceber que, a cada temporada, o número de interações dos personagens sempre tinha a ver com o seu protagonismo. (TEDEBRING, 2017) Assim sendo, um personagem que não estivesse em destaque naquele momento na série não tinha também postagens nas redes. As redes então serviam mais para amplificar o destaque dos protagonistas da temporada, e não para oferecer outras perspectivas ou permitir que se acompanhasse a vida dos personagens que estavam sendo menos explorados pela série.

Esse enfoque também pode ter sido acarretado por uma limitação operacional. Ainda que fosse mais realista que todos os personagens postassem todo o tempo, só Mari operava as redes. Se tivessem feito algum tipo de divisão por personagens, por exemplo, poderia ter sido mais fácil operar mais personagens. Mas talvez pela preocupação de ter um maior controle, ela permaneceu centralizando toda essa tarefa. De todo modo, seu trabalho hercúleo nas redes sociais foi recompensado pela sensação da proximidade que trouxe para os fãs. Alguém podia estar rolando o feed e, de repente, ver, por exemplo, a foto de Vilde, personagem 
que sempre tenta demonstrar que está bem, em sua timeline. Isso a coloca em um patamar próximo ao de seus amigos. Cria identificação, traz para o mundo real a presença da personagem e possibilita a interação dela com os fãs.

Julie e Mari disseram no Mediamorfosis Transmedia que, antes do sucesso, era muito mais fácil usar a parte de comentários dos perfis das redes sociais como parte da narrativa, postando comentários dos personagens de modo a interagir com cada foto, pois havia menos pessoas interagindo. Depois de um tempo, os comentários dos personagens já se perdiam entre muitos outros de fãs, sendo então necessário repensar a estratégia.

Consideravam as postagens das comunidades de fãs como um repositório de informações para uma espécie de focus group permanente. A equipe preferiu manter a parte de comentários do portal como um local para debate entre os fãs, para discutirem os assuntos abordados na série, sem que ninguém do programa dissesse o que era certo ou errado, e optou por não responder diretamente aos fãs, mas mostrar que estavam atentos a eles, ao aproveitar algo dito ou feito por eles no conteúdo da série. (MEDIAMORFOSIS TRANSMEDIA, 2017)

Um fã de Skam da Coreia do Sul (@elli_skam) começou a desenhar suas cenas de Skam e postar em seu instagram. No primeiro clipe da $4^{\text {a }}$ temporada, a composição da cena foi feita em homenagem a uma de suas ilustrações (figura 33). (MEDIAMORFOSIS TRANSMEDIA, 2017)

Figura 33 - Desenho de fã e composição cênica desenvolvida em sua homenagem

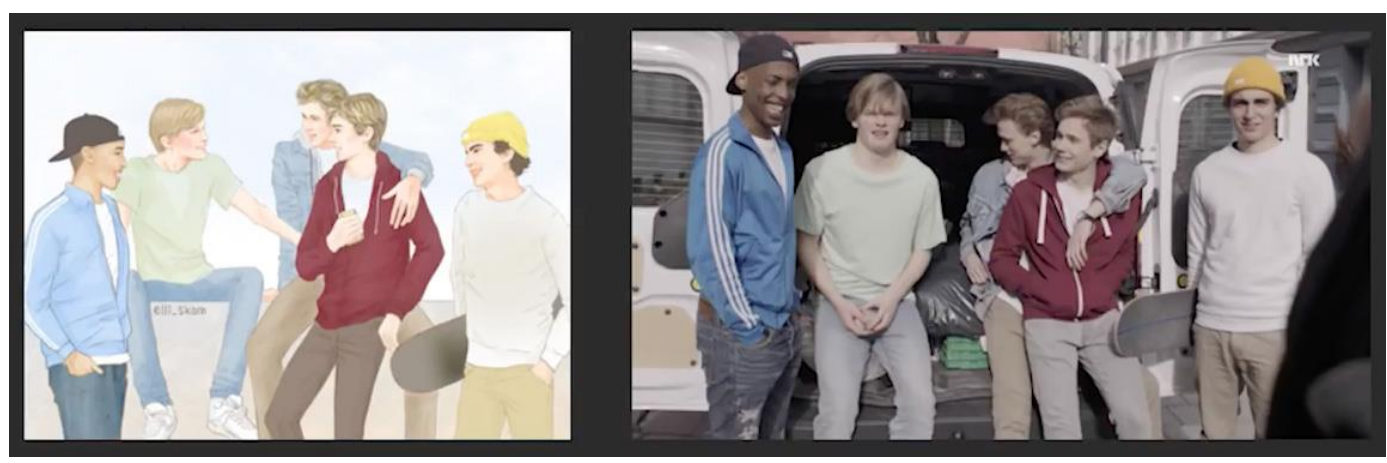

Fonte: vídeo MEDIAMORFOSIS TRANSMEDIA (2017). 
Julie gosta de clichês em sua direção, tais como câmera lenta. Quando, depois da terceira vez que usou o recurso com o personagem William, os fãs fizeram comentários zombando que já tinham entendido e questionando se ela faria isso para sempre, ela fez uma nova cena com o efeito colocando na boca do personagem humor e ironia para comentar o fato. Assim pode seguir com sua câmera lenta.

Do mesmo modo, quando houve uma briga entre o casal Noora e William, em que ele a deixou por um bom tempo sem resposta no whatsapp, os fãs começaram a ficar tão ansiosos quanto Noora. Davam refresh muitas vezes na página para ver se ele já tinha respondido. Começaram a aparecer teorias analisando a situação. Houve uma empresa de telefonia que fez uma propaganda dizendo que se William tivesse o seu serviço, já teria respondido. Um menino comentou que não conseguia se concentrar em sua prova enquanto William não respondesse. Como uma forma de responder a ele indiretamente, as criadoras colocaram a frase do menino no discurso textual da personagem Eva, em um chat de grupo, trazendo para a personagem a sensação da audiência e colocando sua frase em diálogo com as outras personagens. (MEDIAMORFOSIS TRANSMEDIA, 2017)

As criadoras tiveram o cuidado de que cada personagem imprimisse sua personalidade em suas redes. Noora, por exemplo, é sarcástica e faz piadas com seu grupo de amigas, enquanto Vilde tenta mostrar uma vida perfeita, fazendo exercícios, compras, falando sobre maquiagem e sobre sua suposta vida amorosa maravilhosa. Quando acompanhamos sua jornada na série, percebemos que isso não é a realidade, mas é como ela tenta representar sua vida. (PORTAL SKAM. Q\&A, 2018)

As redes sociais também sempre serviram para a promoção da série, chamando atenção para os personagens ou como meio de compartilhamento entre fãs. Para a divulgação de Skam, eles decidiram não fazer propagandas tradicionais e deixar que os adolescentes descobrissem a série por si próprios. Traçaram uma estratégia de relações públicas, onde enviaram para alguns dos mil adolescentes que fizeram audição para papéis na série um clipe promocional em primeira mão. Isso criou um senso de lealdade e pertencimento ao programa, assim muitos compartilharam com seus amigos. 
Na primeira semana da $1^{\mathrm{a}}$ temporada, o portal teve 24.682 visitantes únicos. No final da $2^{\mathrm{a}}$ temporada tiveram 1.262.336 visitantes únicos. (SÉRIE SERIES, 2016)

Outros fatores externos que Julie Andem considerou importantes para o sucesso de Skam foram o fato de vivermos em uma sociedade em que é comum o uso de smart phones, o que facilita a recepção e a produção de conteúdo e de estarmos na era do streaming, o que permite um maior alcance geográfico e temporal de pessoas, permitindo que a série continue a ser consumida após seu término de exibição. Outro quesito destacado foi estarmos em um mundo mais global, onde é possível que pessoas da China e da Turquia se identifiquem com uma série feita para o público norueguês. (MEDIAMORFOSIS TRANSMEDIA, 2017)

\subsection{Construção narrativa em Skam}

Cada temporada é centrada no ponto de vista de um aluno da escola Niessen (escola tradicional que de fato existe na Noruega), entre eles, uma muçulmana e um menino homossexual.

A primeira temporada tem Eva como protagonista: uma garota que acabou de entrar no ensino médio e é muito dependente do namorado, já que ainda não tem amigos na escola nova e ainda tem inimigas por desavenças na escola antiga, sobre as quais ainda não se sabe. Ela começa a ser mais independente quando conhece Noora, Vilde, Chris e Sana.

Juntas formam um grupo para o Russ (figura 34). O Russ é uma tradição na Noruega: os alunos se juntam em grupos de, em geral, 20 a 25 estudantes para comprar um ônibus, que enfeitam e transformam em uma discoteca sobre rodas para fazer festas durante um mês após a formatura. O planejamento do Russ começa logo no início do ensino médio, pois as pessoas precisam arrumar dinheiro e tratar de tudo.

As personagens principais e as perguntas que as criadoras usaram para definí-las são: (SÉRIE SERIES, 2016)

- Eva - ser o que os outros querem que eu seja ou o que eu realmente sou?

- Noora - manter sua moral ou seguir seus desejos? 
- Sana - preocupar-se com os outros é sua força ou fraqueza?

- Chris - ser livre ou aceitar responsabilidades?

- Vilde - ser alguém fake ou um ninguém real?

Figura 34 - Da esquerda para direita: Chris, Vilde, Eva, Noora e Sana

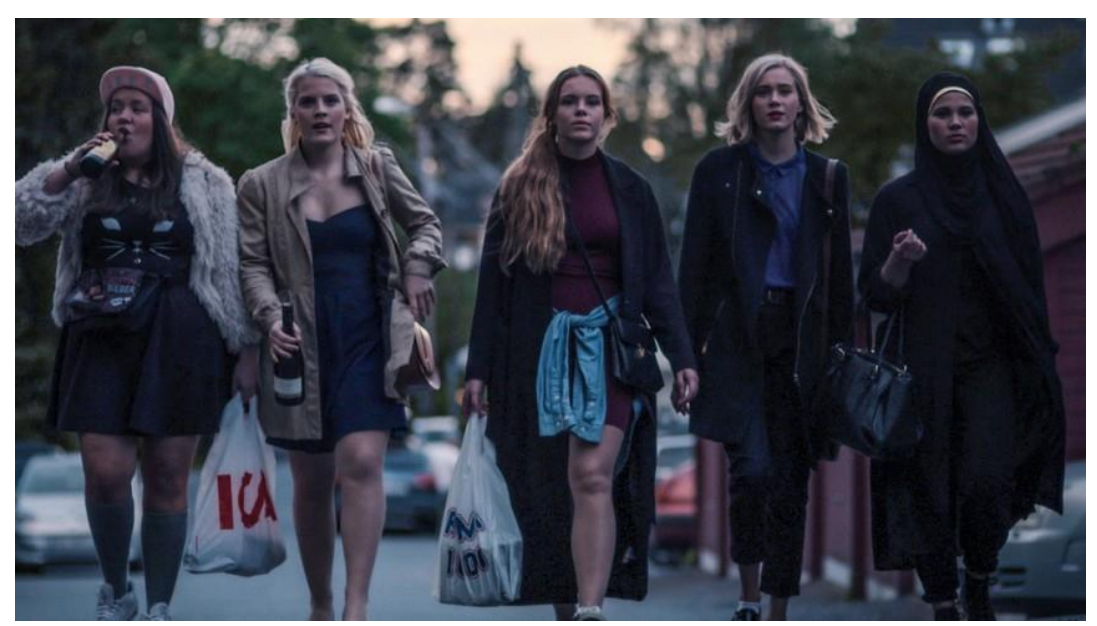

Fonte: PORTAL SKAM

A ideia inicial para a série era começar com Noora, protagonista da segunda temporada, e tratar de seu caso com William. Mas Julie considerou que era preciso criar uma tensão maior entre os dois personagens. Segundo ela, o público tinha que perceber, na primeira temporada, a garota forte que Noora era, mas que tinha dificuldade de deixar alguém entrar na sua vida. Noora era aquela amiga que sempre dizia que não é preciso fazer o que não se quer, que não se tem que estar com alguém popular e que o importante é se sentir bem consigo mesma. Enquanto as outras garotas queriam ser populares e sair com caras mais velhos, ela não ligava. (PORTAL SKAM. Q\&A, 2018)

William também tinha dificuldade em se envolver, mas diferentemente de Noora, que tentava ser sempre correta, William tratava mal e magoava todas as garotas. No final da primeira temporada, vemos que ele começa a se interessar por Noora, mas só na segunda temporada que descobrimos a história de vida difícil por trás de sua armadura. (PORTAL SKAM. Q\&A, 2018)

A autora considerou os dois como um par perfeito, opostos que têm algo a oferecer um para o outro. No entanto, nem todos os fãs concordaram, 
principalmente pelo desejo de continuar a ver Noora como aquela garota forte que não se dobraria para um cara como o William, que já fez tantas coisas ruins. E a forma como o romance começou foi meio chantagista, o que não ajudou muito. Ao longo dos episódios, William conquistou, não só o coração de Noora, como o de muitos fãs, mas, diante de tudo, foi difícil que fosse mantido um consenso a respeito de se ele era bom para Noora. Opiniões à parte, Julie diz que seu intuito foi criar uma história com uma jornada ao contrário do que se espera. De uma garota que é forte e independente, mas que precisa deixar as pessoas entrarem em seu coração. Ela tentou mostrar muitas camadas de William, para que as pessoas o vissem não só como um babaca. (PORTAL SKAM. Q\&A, 2018)

A autora diz que nunca mudaria a jornada de um personagem por conta do público, mas que, quando percebia que eles já estavam contando com algo como certo, mudava alguma coisa pequena, o suficiente para gerar uma surpresa.

O protagonista da terceira temporada é Isak. O desejo de que houvesse uma temporada com sua perspectiva surgiu na metade da primeira temporada. Julie percebeu o interesse dos fãs pela homossexualidade quando, em uma cena na cabana, após um comentário displicente de Jonas zoando que Isak era gay pela escolha das músicas no violão, os fãs se mostraram intrigados. (MEDIAMORFOSIS TRANSMEDIA, 2017)

Vale lembrar que essa escolha talvez tenha afastado o objetivo para com o público alvo inicial, mas ajudou a levar Skam para outro patamar.

O romance entre Isak e Evan foi uma história de amor que emocionou, como um todo, a base de fãs e ainda levou mais gente a buscar pela série. Os desafios a serem superados foram além dos clichês esperados, envolvendo conflitos para se encaixar em estereótipos e de como respeitar todos os perfis homossexuais, além de outros tipos de problemas que podem surgir em qualquer tipo de casal, além da relação da homossexualidade com a religião e a biologia.

Em 2017, o casal Isak e Evan ganhou o reconhecimento de casal do ano pela revista americana de entretenimento E! Online, com cerca de 3 milhões de votos. (TEDX TALKS. SKAM, 2017)

Inicialmente, o plano de Julie era fazer 3 temporadas e depois entregar o roteiro e direção para outra pessoa, mas não conseguiu fazer isso, decidindo então 
fazer mais uma temporada para encerrar a série. Pela popularidade da série, Julie considerou que deveria passar a perspectiva narrativa para Sana, acreditando assim poder contribuir para as garotas muçulmanas da nossa sociedade. A atriz que interpreta Sana, Iman, ser muçulmana foi imprescindível para que se evitasse qualquer compreensão equivocada que a roteirista pudesse ter sobre os anseios das garotas muçulmanas. A maior dificuldade foi porque não há uma uniformidade de pensamentos, diferentes garotas possuem distintas opiniões. Algumas queriam que se falasse como se sentem socialmente controladas ao usar o Nihab, outras que o usam por escolha própria. Para conciliar essas divergências foi preciso muita pesquisa. (PORTAL SKAM. Q\&A, 2018)

De uma forma geral, Skam ajudou a cruzar fronteiras, mostrando menos homofobia e tolerância. Muitos fãs relataram que a história de amor entre Isak e Evan os ajudou a assumir sua homossexualidade e a história de Sana, uma garota forte e que enfrenta seus desafios diários com seu Nihab, foi tida como importante para muitas jovens muçulmanas em países como Turquia, Rússia e Estados Unidos. (PORTAL SKAM. Q\&A, 2018)

\subsection{Ponto de vista em Skam}

Existe uma teoria dos fãs a respeito da mudança de perspectiva a cada temporada implicar na mudança dos outros personagens, a partir de como são vistos pelo protagonista.

Quando the perguntaram sobre essa teoria em um vídeo, Julie disse que nunca instruiu os atores a atuarem de maneira diferente, mas que é verdade que cada temporada é vista por um personagem diferente, por outro ponto de vista e que, consequentemente, isso acaba por alterar a forma com que os personagens interagem. Ela acredita que a possível mudança na atuação pode ocorrer pelo ator perceber que precisa alcançar um outro nível emocional para seu personagem. (PORTAL SKAM. Q\&A, 2018)

Ainda que não tenha sido proposital, talvez só o fato do roteiro eleger um olhar, já acabe influenciando no que é escrito para os personagens, ainda que de modo inconsciente, pelo que pareceu. Talvez isso naturalmente tenha contribuído para uma diferença nos demais personagem. 
Trazendo para a tese um pouco da minha própria experiência com a série, eu vi todas as temporadas sem ler ou ver nada sobre ela, pois não queria sofrer influências externas na minha percepção. Preciso concordar com muitos fãs face a estranheza que as mudanças de perspectiva me causaram em relação a alguns personagens. Eva, por exemplo, virou quase uma "louca perdida" quando deixou de ser protagonista; já a personagem de Vilde se manteve mais coesa em todas as temporadas, mas ela não protagonizou nenhuma. Mas queria me ater às mudanças da personagem Noora. Se pensarmos em sua trajetória por completo, fazendo um arco de todas as temporadas, parece que houve uma certa inconstância na construção da personagem.

Na primeira temporada, Eva a vê como uma menina super cool e dona de si. Na segunda temporada, em que temos o seu próprio ponto de vista, já não a vemos tão forte assim, mas confesso que, apesar disso ter incomodado muitos fãs, acredito que faça sentido, uma vez que era o momento de enfocar os seus dramas e inseguranças e a série deixa claro que todos aqueles que você conhece estão passando por problemas sobre os quais você nada sabe, fazendo, assim, todo o sentido. Na terceira temporada na visão de Isak, ela parece uma chata que só sabe reclamar e na quarta não sabemos o que se passa com ela, fazendo-a parecer uma amiga omissa.

Analisando a jornada completa dos personagens da série, parece que essa divisão de ponto de vista por temporada gerou inconstância para o desenvolvimento dos personagens.

Talvez essa mudança de percepção dos personagens funcionasse melhor se a divisão fosse mais episódica do que pela temporada completa, ou se a personalidade de cada personagem tivesse sido mantida mais constante, apesar do ponto de vista, ainda que explorar como cada personagem vê os outros também possa ser uma premissa interessante. Ou talvez o problema tenha sido porque claramente não havia um arco prévio de desenvolvimento para os personagens. A série começou totalmente como uma obra aberta e, pelo que parece, sem saber onde queria chegar.

Ocupando o lugar de público, essa mudança de perspectiva também me incomodou um pouco no início da terceira temporada, pois como a visão passou a 
ser a de Isak, o relacionamento desenvolvido com aquele grupo de 5 amigas se perdeu um pouco. Era como se eu quisesse saber delas e, no lugar, me obrigassem a saber dele. Somava-se a isso o fato de que eu não tinha uma maior simpatia pelo personagem, por ter contribuído, de propósito, na primeira temporada, para estragar o relacionamento do casal Eva e Jonas, seus melhores amigos. Ao longo da temporada, acabei me reconectando com a série, até porque a história de amor entre ele e Evan foi muito bem apresentada, explorando também vários subtemas interessantes. No fim, acabei melhorando a simpatia por Isak, mas fiquei feliz pela quarta temporada ser sobre a Sana, porque assim, além de gostar da personagem, ia poder voltar a estar com o grupo das meninas.

Faz sentido que as diferenças de percepção de cada personagem aconteçam em uma narrativa multiperspectiva, uma vez que sempre se sabe de outros personagens a partir do ponto de vista de quem narra, mas me questiono se essa divisão contribuiu para o arco da série. Ou se o mais importante seria valorizar a relativização das construções dos personagens.

Na série The Affair, analisada anteriormente, também temos mudanças de pontos de vista, mas acredito que lá tenha funcionado melhor. Como o episódio é dividido em duas partes, onde temos os mesmos momentos narrativos, ou momentos narrativos consecutivos, representados a partir de diferentes pontos de vista em um mesmo episódio, essas perspectivas não abalam a construção dos personagens. Ao longo da série acompanhamos a trajetória de cada personagem em cada uma das visões. As diferenças de percepção, assim, não são capazes de abalar a identidade do personagem. Imaginamos que, na realidade, a personalidade real de cada um deve estar em algum lugar entre cada perspectiva, mas todas as construções se prolongam no tempo, coexistindo de maneira até natural.

No entanto, as críticas tecidas acima não tiram o mérito da série Skam, que construiu uma narrativa capaz de interessar a um público tão vasto. Por ser uma série local que se tornou um sucesso global, Skam acabou por exportar os valores culturais noruegueses para o mundo.

Acredito que tenha sido sensata a forma escolhida de deixar para a audiência a opção de ver o programa em tempo real, tendo uma experiência super imersiva na 
trama, podendo acompanhar também as redes sociais dos personagens, ou ver um episódio completo no fim da semana de maneira fácil.

Na Noruega, dentro de seu público alvo, Skam superou a audiência de Game of Thrones. (MEDIAMORFOSIS TRANSMEDIA, 2017) Parte do sucesso provém da seriedade e delicadeza com que foram tratados temas realmente relevantes para sua audiência. Muitos fãs já relataram, em suas redes sociais, como Skam os ajudou a enfrentar sua própria vida.

Ao redor do mundo, fãs continuam vendo as adaptações como uma forma de manter contato com um conteúdo que os tocou. É interessante notar que, frequentemente, essas adaptações acabam por preencher lacunas que muitas vezes são preenchidas pelas fanfictions. Fãs que não gostaram do desfecho original da personagem de Eva, por exemplo, fizeram campanha para que, na adaptação, ela ficasse com o personagem correspondente ao de Chris Penetrator, ou que tivesse uma relação lésbica com Noora.

A atriz que interpreta Wilde, Ulrikke Falch lançou uma fanfiction $^{39}$ do que poderia ser a temporada 5 de Skam, que teria como protagonista a sua personagem. Essa fanfiction escrita em um único capítulo, foi leiloada junto aos roteiros originais de Skam, em um evento em prol da UNICEF, em outubro de 2017. É a atriz também se apropriando da personagem e fazendo com que a narrativa se desdobre, nesse caso, em uma versão não oficial, mas realizado por quem trouxe à vida nas telas a personagem.

O conteúdo estando presente na internet de maneira legal e ilegal, permite que novos fãs ainda tenham acesso à série e que sua comunidade continue crescendo, ainda mais com as adaptações conquistando o público de outros países.

Esquenazi define intimidade como o trabalho de coordenação entre imagem pública e presença de uma continuidade pessoal e acrescenta que:

A presença de uma variação entre a minha presença face à comunidade social, ou as minhas presenças sucessivas face a vários tipos de comunidades sociais e a minha própria tentativa de os unificar dá origem ao sentimento de intimidade e necessita da sua manutenção. A possibilidade de oferecer o espetáculo da intimidade de outrem é uma das mais extraordinárias da ficção: está na origem de numerosos processos, como a voz interior ou a narração subjetiva. Não há dúvida

\footnotetext{
39 A fanfiction de Ulrikke Falch pode ser lida no wattpad de um fã em versão traduzida para o português em: https://www.wattpad.com/story/128880051-skam-vilde-s5
} 
de que a série televisiva é grande apreciadora desta forma de espetáculo. (ESQUENAZI, 2010, p. 139)

Podemos complementar a citação de Esquenazi, dizendo que diferentes pontos de vista trazem a possibilidade de serem criados diálogos entre os personagens, interpretados a partir de distintas subjetividades e que a transmídia abre espaço para que isso seja realizado através de diferentes plataformas. Os criadores precisam, então ter a identidade de seus personagens muito clara e entender como cada personagem enxerga o outro, com base em sua construção social da realidade. Se não houver um denso trabalho desenvolvido nesse sentido, há o forte risco dos personagens se mostrarem inconstantes e não deliberadamente diferentes, por conta de quem o vê.

O autor cita Roberta Pearson, que defende que o personagem serial tem de começar por ser tipificado e estável, para facilitar a compreensão do público: que ele deve a princípio parecer mais ou menos igual a ele próprio, a fim de que sua identidade seja constituída. Deve-se também evoluir eventualmente os personagens, sob o risco da repetição se tornar entediante. Esquenazi defende que os encontros com outros personagens funcionam como espelhos para eles, permitindo aos produtores aprofundarem e alargarem sua definição. Esse jogo de relações aumenta a intimidade que temos com o personagem. (ESQUENAZI, 2010)

A adaptação americana Skam Austin (2018) segue a mesma lógica de narrativa transmídia de Skam original, incluindo a reprodução das cenas que simulam a publicação em tempo real. A sua especificidade é ser veiculada na plataforma facebook watch, plataforma de vídeos do facebook, e estar oficialmente acessível a todos, inclusive ao público estrangeiro.

A showrunner da série, Karen DiConcetto, comenta com a Teen Vogue 40 sobre a experiência:

É uma colaboração completa e total. Ter conteúdo saindo todos os dias em diferentes plataformas, no instagram e no facebook para os clipes significa que estamos pensando de uma maneira muito mais de construção de universo, em oposição a algo mais micro. (...) Desde o início, fiquei muito empolgada por poder

\footnotetext{
${ }^{40}$ Entrevista presente em Teen Vogue: https://www.teenvogue.com/story/skam-austin-season-twoviral-hit
} 
contar histórias dessa maneira, porque é imersivo e muito diferente de tudo o que já havia feito parte. ${ }^{41}$

Podemos destacar dessa frase dois aspectos. O primeiro é lembrar a construção de universo que uma narrativa transmídia demanda. É como se você construísse um mundo e cada nova mídia criada é uma nova janela para acessá-lo. O segundo é a consequente imersão proporcionada. A narrativa transmídia trás para o personagem um nível de realismo que se assemelha ao nosso realismo cotidiano. Isso significa que o trabalho para garantir que as identidades não se percam é ainda maior.

Em Skam Austin, os atores adolescentes também tinham total abertura para questionar se algo no roteiro não fosse condizente às suas realidades ou sobre a forma que seus personagens estavam se comunicando nas redes, pois seus criadores queriam produzir narrativas autênticas, garantindo que todas as postagens que realizassem, desde o upload de música ou qualquer mudança, como uma troca de foto de perfil, pudessem se manter de acordo com a personalidade do personagem.

Autenticidade se refere ao que é autêntico, real e genuíno por natureza. Em seu livro Sinceridade \& Autenticidade: a vida em sociedade e a afirmação do eu, Lionel Trilling considera que a autenticidade é uma forma que propicia que sejamos mais verdadeiros com nosso próprio eu. (TRILLING, 2014) Dissemos anteriormente que o testemunho passa uma ideia de sinceridade. Mas se for preciso desenvolver um conteúdo para ser postado por um personagem em suas redes sociais, o que seria mais importante: alcançar a sinceridade ou a autenticidade?

A sinceridade exige um alinhamento da verdade em congruência com nossos sentimentos. A autenticidade exige um alinhamento das nossas atitudes de acordo com uma identidade já reconhecida pelos outros como sendo nossa. Nas redes sociais, vistas como um painel demonstrativo de uma identidade já consagrada com seus seguidores, espera-se que as pessoas postem imagens e textos que lhes representem.

\footnotetext{
${ }^{41}$ Livre tradução de: It's a complete and total collaboration. Having content coming out every day on different platforms, on Instagram, and on Facebook for the clips means that we're thinking in a very world-building kind of way as opposed to something very micro," showrunner Karen DiConcetto told Teen Vogue. "From the very beginning, I was so excited about being able to tell stories in this way because it's so immersive and it's so different than anything I'd ever gotten to be a part of before.
} 
Trilling defende que a palavra autenticidade sugere uma experiência moral mais tenaz que a sinceridade, mas que antes que pudesse surgir, insinuando uma deficiência do termo sinceridade, esta dominou a ideia do que os homens deveriam ser. (TRILLING, 2014)

\begin{abstract}
Certamente não é acidental o fato de a ideia da sinceridade, do eu próprio e da dificuldade de conhecê-lo e revelá-lo só ter surgido para atormentar as mentes humanas na época que viu o florescimento do teatro. Uma famosa obra contemporânea de sociologia traz como título The presentation of Self in everyday life $^{42}$ (A representação do eu na vida cotidiana), e podemos pressupor que o Hamlet de hoje diria: Trago mais do que apresento". nesta tarefa de apresentar o eu, de posicionar-nos sobre o palco social, a própria sinceridade desempenha um papel curiosamente comprometido. A sociedade exige que nos apresentemos como seres sinceros, e a forma mais eficaz de cumprir essa exigência é assegurando que nós somos sinceros de fato, que realmente somos o que queremos que a comunidade ache que somos. Em suma, nós interpretamos o papel de nós mesmos, desempenhamos com sinceridade a função da pessoa sincera, e disso resulta que um juízo que se debruce sobre nossa sinceridade pode muito bem declará-la inautêntica. (TRILLING, 2014, p. 21)
\end{abstract}

Ele lembra que a ideia de que o mundo é um palco e que somos meros atores é antiga, estava no The Globe, teatro de Shakespeare: totus mundus facit histrionem.

O autor considera que não há alternativa à representação, que é possível apenas escolher entre um papel e outro, mas também vê nisso um lado positivo: a vida nos oferece escolhas, alternativas. A palavra sinceridade apareceu na língua inglesa no primeiro terço do século XVI, tempos depois do vocábulo ser utilizado na França. Deriva do Latino sincerus que significa limpo, leal e puro. O termo se referia primeiramente a coisas e não a pessoas. Os objetos de arte que não eram remendados se apresentavam sem cera, assim sendo originais, não corrompidos. Começou a ser empregado para pessoas no início do século XVI como uma metáfora: a vida de uma pessoa poderia ser considerada sincera no sentido de legítima e completa. Depois sua ausência passou a caracterizar simulação ou fingimento. Trilling lembra que ser fingido era muito malvisto no século XVI, tanto que Dante enviou essas pessoas para o penúltimo círculo do inferno. Após a era vitoriana, os personagens tidos como vilões em geral eram alguém que fingia ser algo que não era. Cita autores que sustentam que a sinceridade passou a remeter-se a uma personalidade do tempo passado, encontrando-se entre o eu e a desintegração

\footnotetext{
${ }^{42}$ A obra The presentation of Self in everyday life, a qual Trilling se refere é de autoria de Erving Goffman (1956).
} 
que é essencial para que ele desenvolva sua liberdade verdadeira e plena; e que acreditam no poder das máscaras para comunicar as verdades dos homens, pois estas máscaras refletem uma identidade que criamos para nós mesmos. (TRILLING, 2014)

Se só resta a nós e aos personagens as escolhas entre diferentes máscaras, que elas comuniquem o melhor possível nossas naturezas, constituindo representações autênticas de nós mesmos. E que as posturas dos personagens, tanto na série quanto em suas redes, sejam condizentes com o que se constrói deles, de modo a garantir que o pacto da ficção se mantenha.

É preciso também estar atento para criar ganchos na narrativa que levem o espectador de uma rede à outra.

Jenkins considera que, em geral, uma narrativa transmidiática é baseada, não em um personagem individual ou enredo específico, mas em complexos universos ficcionais, os quais podem sustentar múltiplos entrelaçamentos de personagens e suas histórias. Considera que esse processo de construção de universos encoraja um impulso enciclopédico, tanto em leitores quanto em autores. Considera que o prazer trazido por esse tipo de histórias é diferente ao da narrativa clássica, de completude, de entender todo o sentido da história após o término da sessão: somos atraídos para saber mais sobre um mundo que se expande além do nosso conhecimento. (JENKINS, 2007)

A transmídia pode, então, ampliar um universo narrativo em diversos aspectos: oferecendo histórias como pano de fundo; mapeando; trazendo mais informações; apresentando realidades paralelas; agregando realidade à ficção; mantendo o interesse do público por uma série no intervalo entre as temporadas; aumentando o engajamento da audiência; oferecendo outras perspectivas e revelando mais sobre os personagens e suas motivações.

A presença em múltiplas mídias torna os personagens mais convincentes, ao passo que também permite um maior conhecimento de seus anseios e vivências. $\mathrm{O}$ universo ficcional criado para os produtos transmidiáticos ganha engajamento do público quanto mais sua completude permite diferentes experiências. (JENKINS, 2003) 


\section{Conclusão}

Ao longo da última metade do século passado, o espectador da TV passou a ser tido como um espectador disperso. As séries complexas, ao demandarem um significativo esforço cognitivo, reconquistaram o espectador concentrado diante da tela: ele não quer perder nenhuma frase, nenhuma informação, pois cada detalhe pode ser uma peça que falta para completar o quebra-cabeça narrativo que reconstrói os acontecimentos da história.

Os meios mudaram consideravelmente desde o surgimento da TV. Os hábitos do público também se alteraram, diante das novas possibilidades que consideraram condizentes com seus anseios. Não sabemos o que está por vir, mas sabemos que a cada nova tecnologia que surge e é adotada pelo mercado, toda a ecologia dos meios se adapta a essa nova presença e alguns se modificam, seja para se diferenciar, operar em parceria ou incorporar algumas de suas funções.

Nessa tese, analisamos narrativas complexas e transmídias, mas é importante sublinhar que nem todas as narrativas que são vistas na atualidade apresentam essas formas em suas histórias. Narrativas que estimulam nosso cérebro para juntar fragmentos dispersos, desenvolver teorias possíveis e debater sobre isso com fãs têm seu valor e seu momento, não sendo melhores nem piores que outros tipos de narrativa. Às vezes se quer ver algo que apenas ajude a descansar a cabeça de todo o caos que é a vida, sem a exigência de grande esforço cognitivo, próatividade ou memória. O importante para as histórias é sempre a criação de laços com o seu público e estes são criados por uma boa história, seja qual for a sua forma.

As séries, por conta do formato fragmentário e da exibição estendida, tornaram possível a complexidade de uma maneira que outras formas de narrativa não conseguiram, exceto em conjunto agregando múltiplos conteúdos em uma experiência transmídia. Elas permitem que se entrelacem muitas tramas, temporalidades e extensões narrativas. É possível estender, desdobrar, multiplicar e aprofundar os personagens.

Starling considera que, nesse ponto, as séries estão mais próximas da Literatura que do Cinema. Séries de longa duração possibilitam a criação de personagens mais elaborados. Garantem uma audiência fiel por um longo período, que quer saber sobre os desdobramentos da história e a evolução de seus 
protagonistas, os quais podem se transformar em profundidade, já que a regularidade serial os obriga a manterem uma estabilidade persistente, que pode ser remodelada com novos nuances com o passar do tempo. (STARLING, 2006)

É interessante notar que, ainda que os meios tenham sofrido grandes transformações nos últimos anos, algumas características das narrativas que Aristóteles identificou em sua poética, que data de mais de 300 anos AC, se mantêm presentes até hoje. Segue havendo personagens que, por seus propósitos, se envolvem em uma sucessão dramática de eventos, enfrentando conflitos que chegarão ao seu clímax e resolução, ainda que possam ser complexificados e as resoluções deixadas em aberto, para serem completadas pelo público. As três unidades da ação dramática, de alguma forma, persistem: tempo, lugar e ação. O que a narrativa complexa faz é multiplicar os dados de cada uma dessas unidades, possibilitando que se criem inúmeros entrecruzamentos e relações, propiciando também mais oportunidades para peripécias e reconhecimentos. A peripécia acontece quando a história parece tomar um rumo linear e algo ocorre que surpreende o público com uma mudança de caminho. O reconhecimento é quando um personagem percebe ou descobre algo que não sabia, sendo o tipo mais instigante aquele em que ele junta peças e raciocina para chegar ao desvelamento.

Segundo Maciel, a grande diferença da tragédia para o drama moderno é a magnitude de sua ação principal:

O conflito do herói trágico é com a dimensão metafísica da realidade, um poder que o ultrapassa em tal medida que ele está condenado inexoravelmente à destruição. O herói do drama moderno enfrenta obstáculos também poderosos, a estrutura e o comportamento da sociedade, por exemplo, mas eles não são transcendentes como os trágicos, sua medida é humana." (MACIEL, 2003, p. 27, 28)

O autor lembra que, para Aristóteles, os personagens da tragédia deveriam estar no meio termo entre o vício e a virtude para a história não parecer absurda. Não deveriam ser nem tão bons e nem tão maus, porque sendo demasiado bons o público acharia uma injustiça que passassem por tantas provações e, do contrário, sendo demasiado ruins, iria considerar que mereciam toda a punição e não se conectariam com eles. Os personagens das séries que analisamos tem seus vícios e virtudes. Em Thirteen Reasons Why, Hannah já desde a primeira temporada era mostrada com esse balanço, mas Bryce estava mais para um vilão. Talvez por isso, 
na terceira temporada, os autores da série tenham sentido a necessidade de mostrar suas virtudes, para que pudéssemos vê-lo também como uma pessoa e não como alguém que, por sabermos o que fez, merecesse apenas punição.

A perspectiva do personagem afeta o que ele sente em relação às experiências que vive e o que pensa sobre os outros personagens: as séries estudadas tiram partido dessa variação dos pontos de vista. Na vida real, cada perspectiva diante de um evento é única, pois é originada pela experiência de um observador específico.

As dissonâncias e as ambiguidades desconstroem o padrão clássico das narrativas e enfatizam as noções de relatividade da verdade, ao mesmo tempo que engajam os espectadores de maneira ativa, conscientes de sua co-criação e de seus significados conotativos e denotativos. (WILLEMSEN, 2018)

Em The Affair, as incongruências narrativas e as pequenas dissonâncias, como as roupas diferentes que os personagens usam em cada versão, deixam o espectador consciente de seu envolvimento na construção do enredo: essas incongruências problematizam o relato.

A complexidade na narrativa se assemelha à complexidade da vida. Será que, então, essas visões plurais podem obrigar o público a interpretar, ponderar e refletir, levando a experiência da ficção para o campo de suas próprias vidas? Será que a ficção pode nos ajudar a questionarmos nossas próprias verdades, que por vezes temos como cristalinas, e estarmos abertos para entender a interpretação do outro?

Tendo em vista o poder da ficção de estimular as faculdades cognitivas humanas, estar em contato com ficções que possam expandir nossos horizontes, talvez torne isso possível.

Sendo assim, uma história contada de modo fragmentário, apresentando múltiplos pontos de vista, seja em uma mesma tela, seja em diferentes plataformas, poderia ser capaz de alterar a experiência de consumo narrativo de quem a assiste e, de alguma forma, influenciar o modo como o público vê o mundo. Pode influir na forma com que essas pessoas constroem sentido, procurando ter em conta mais visões e refletindo sobre as condições em que os relatos são construídos. 
As narrativas não são contadas a partir de pontos de vistas neutros, o que já incomodava os modernistas, que alertavam para a incapacidade de ser alcançada uma realidade objetiva. As multiperspectivas chamam atenção para a inexistência da história única e lembram que todos são protagonistas de suas próprias histórias.

$\mathrm{O}$ ato de desconfiar da narrativa não é um defeito. Inclusive é sempre importante lembrar que a ficção é um jogo narrativo. É curioso como temos o impulso de cobrar a verdade mesmo numa ficção. Talvez tenhamos que pensar que a ficção deve nos revelar as verdades dos personagens. É por eles que nos conectamos às narrativas, pela empatia e identificação, dessa forma nos envolvemos emocionalmente com seus objetivos e devoramos as tramas para saber o que se sucederá a eles. Mesmo que sejam narradores não confiáveis, com uma visão subjetiva, o que importa é que nos façam embarcar em uma viagem de descobrimentos sobre eles e sobre nós mesmos.

E tudo é relativo. Até o conceito de presente pode ser relativo. No documentário Nostalgia da Luz, de Patricio Guzmán (2010), um astrônomo comenta que o que vemos como presente já não existe. $\mathrm{O}$ único tempo real é o tempo que vem do passado, o presente é invisível. O que nos permite enxergar é a luz que incide em um objeto e é rebatida, ou a radiação própria de um objeto luminoso, que chega até nossos olhos, é recebida pela retina e processada para o nosso cérebro. A luz do sol, devido a sua velocidade e distância espacial, demora cerca de oito minutos para chegar até nós, a luz refletida da lua, dois segundos. Assim, quando olhamos para os astros no céu o que vemos é o passado, quando olhamos para uma cena em tempo real, as imagens dos objetos ou das pessoas que vemos foram formadas milésimos de segundos atrás.

Tendo então em conta que até o que consideramos como presente imediato é passível de ser relativizado, o que não seria? Nossa tarefa talvez possa ser conviver com a subjetividade do mundo e estarmos atentos para o fato de que se uma cena apresenta mais de um personagem, já não existe uma história única. 


\section{Referências bibliográficas}

ANDERSON, Robert. The Rashomon effect and Communication. In. Canadian Journal of Communication. Burnaby: Simon Fraser University, v. 41, p. 249-269, 2016.

ARFUCH, Leonor. O espaço biográfico: dilemas da subjetividade contemporânea. Rio de Janeiro: Ed. Uerj, 2010.

ARISTÓTELES. Arte retórica e arte poética. São Paulo: Difusão Européia do Livro, 1959.

1998.

. Poética. Tradução de Eudoro de Sousa. Lisboa: Imprensa Nacional,

AUSTEN, Jane. Orgulho e Preconceito. Tradução de Lúcio Cardoso. São Paulo: Abril Cultural, 1982.

BAKHTIN, Mikhail. O autor e a personagem na atividade estética. In: Estética da criação verbal. São Paulo: Martins Fontes, 2003.

Problemas da Poética de Dostoievski. Rio de Janeiro: Forense, 2013.

BALOGH, Anna Maria. Os replicantes: séries e seriados; As Minisséries: La creme de la creme. In: $O$ discurso ficcional na TV. São Paulo: Editora da Universidade de São Paulo, 2002.

BERGER, Peter L.; Luckmann Thomas. A construção social da realidade: um livro sobre a sociologia do conhecimento. Lisboa, 2004.

BLANCO, André. Transmídia Storytelling na Propaganda: uma Nova Estética para um Novo Cenário. Monografia - Faculdade de Comunicação Social. Revista da Graduação. v. 4, n. 2. Porto Alegre: EdPUCRS, 2011. Disponível em:

$<$ http://revistaseletronicas.pucrs.br/ojs/index.php/graduacao/article/view/10037/70 78>. Acesso em: 16 jun. 2014.

BORELLI, Silvia. Do folhetim à crônica: espaço literário e indústria cultural. In: Ação, suspense, emoção. Literatura e cultura de massa no Brasil. São Paulo: EDUC, 1996.

BOURDIEU, Pierre. A ilusão biográfica. In: AMADO, Janaina \& FERREIRA, Marieta M. (orgs.). Usos e abusos da história oral. Rio de Janeiro: Fundação Getúlio Vargas, 1996.

BRANIGAN, Edward. O plano-ponto-de-vista. In: RAMOS, Fernão Pessoa (org.). Teoria contemporânea do cinema, volume II. São Paulo: Editora Senac São Paulo, 2005.

BRITO, Danilo Lopes; BONA, Fabiano Dalla. Sobre a noção de estereótipo e as imagens do brasil no exterior. In: Revista Graphos, v. 16, n. 2, p. 15-28, 2014. 
CASTELLANO, Mayka; MEIMARIDIS, Melina. A ascensão do showrunner: autoria e legitimidade na era da peak TV. In: HOLZBACH, Ariane;

CASTELLANO, Mayka (orgs.). Televisões: reflexões para além da TV. Rio de Janeiro: E-papers, 2018.

CONCEIÇÃO, Juara Castro da; BORGES, Rosana Maria. Complexidade narrativa na TV brasileira: uma análise de "Justiça" a partir dos conteúdos de opinião. Cuiabá: Anais do XIX Congresso de Ciências da Comunicação na Região Centro-Oeste, ano 2017.

COOK, Glenn. 13 Reasons Why to Take Action. In: American School Board Journal (asbj). Alexandria, ago 2017, p. 36-38. Disponível em:

<http://media.virbcdn.com/files/b3/90fad19f3d05d3b3-asbj-13reasons.pdf>. Acesso em: fevereiro de 2020.

CURI, Pedro Peixoto. À margem da convergência: hábitos de consumo de fãs brasileiros de séries de TV estadunidenses. Tese de Doutorado em Comunicação, Universidade Federal Fluminense, 2015.

DERRIDA, Jacques. História da mentira: prolegômenos. In: Estudos Avançados, São Paulo, v. 10, n. 27, p. 7-39, 1996.

DIAS, Mariana Castro. Narrativas transmidiáticas: criando histórias na era da convergência dos meios. Dissertação de Mestrado em Comunicação Social, Pontifícia Universidade Católica do Rio de Janeiro, 2015. Disponível em: http://www.dbd.puc-rio.br/pergamum/tesesabertas/1312520_2015_completo.pdf

DIDI-HUBERMAN, Georges. Sobrevivência dos vagalumes. Belo Horizonte: Editora UFMG, 2011.

ECO, Umberto. A inovação no seriado. In: Sobre os espelhos e outros ensaios. Rio de Janeiro: Nova Fronteira, 1989.

ESQUENAZI, Jean-Pierre. As séries televisivas. Lisboa: Texto \& Grafia, 2010.

EÖRDÖGH, Fruzsina. Transmedia Shows are Winning the Internet. In:

Motherboard. 10 abril 2014. Disponível em:

<http://motherboard.vice.com/read/transmedia-shows-are-winning-the-internet>. Acesso em: 7 jun. 2014.

FIELD, Syd. Roteiro: os fundamentos do texto cinematográfico. Rio de Janeiro: Objetiva, 2001.

FIGUEIREDO, Vera Lúcia Follain de. Ficção e resistência na cultura de arquivo. In: Revista Matrizes, São Paulo, v. 11, n. 3, p. 57-70, set/dez 2017.

Narrativas Migrantes: Literatura, Roteiro e Cinema. Rio de Janeiro:

Editora PUC Rio, 7Letras, 2010.

FLUSSER, Vilém. Filosofia da caixa preta. São Paulo: Editora Hucitec, 1985. 
GRANDÍO PÉREZ, María del Mar. Tempo y perspectiva en la película Rashomon de Akira Kurosawa. In: Revista de Comunicación Vivat Academia, Espanha, ano XIII, n. 111, p. 87-105, junho 2010. Disponível em: <https://www.vivatacademia.net/index.php/vivat/article/viewFile/212/202>

HALBWACHS, Maurice. A memória coletiva. São Paulo, Centauro, 2006.

HALL, Stuart. Quem precisa de identidade? In: SILVA, Tomaz Tadeu da (org.). Identidade e diferença: a perspectiva dos estudos culturais. Petrópolis, RJ: Vozes, 2000.

JENKINS, Henry. Cultura da Convergência. 2. ed. São Paulo: Aleph, 2009a.

Now Available: Transmedia Hollywood 2 Videos. Confessions of an Aca-Fan: the Official Weblog of Henry Jenkins, 1 julho 2011a. Disponível em: <http://henryjenkins.org/2011/07/transmedia_hollywood_2_videos.html >. Acesso em: 20 jan. 2014.

The Revenge of the Origami Unicorn: Seven Principles of Transmedia Storytelling. Confessions of an Aca-Fan: the Official Weblog of Henry Jenkins, 12 dez. 2009b. Disponível em:

<http://henryjenkins.org/2009/12/revenge_of_the_origami_unicorn.html > . Acesso em: 20 jan. 2014.

Transmedia Storytelling 101. Confessions of an Aca-Fan: the Official Weblog of Henry Jenkins, 22 mar. 2007. Disponível em:

<http://henryjenkins.org/2007/03/transmedia_storytelling_101.html>. Acesso em: 20 jan. 2014.

Transmedia 202: Further Reflections. Confessions of an Aca-Fan: the Official Weblog of Henry Jenkins, 1 ago. 2011b. Disponível em:

<http://henryjenkins.org/2011/08/defining_transmedia_further_re.html>. Acesso em: 20 jan. 2014.

Transmedia Education: the 7 Principles Revisited. Confessions of an Aca-Fan: the Official Weblog of Henry Jenkins, 21 junho 2010. Disponível em: <http://henryjenkins.org/2010/06/transmedia_education_the_7_pri.html>. Acesso em: 20 jan. 2014.

Transmedia Storytelling. MIT Technology Review, 2003. Disponível em: <http://www.technologyreview.com/Biotech/13052/>. Acesso em: 17 abril 2012.

JENKINS, Henry; FORD, Sam; GREEN, Joshua. Spreadable Media: Creating Value and Meaning in a Networked Culture. Kindle ed. New York, London: New York University Press, 2013.

JOST, François. Do que as séries americanas são sintomas? Porto Alegre: Sulina, 2012. 
KAMIR, Orit. Judment by film: social-legal functions of Rashomon. In: 12 Yale J. L. \& Human. v. 12, iss. 1, art. 2 - 39-88, 2000.

KINDER, Marsha. Playing with Power in Movies, Television, and Video Games: From Muppet to Teenage Ninja Turtles. Berkeley: University of California Press, 1991.

LANDOW, George P. Hypertext 2.0: The Convergence of Contemporary Critical Theory and Technology. Baltimore: The Johns Hopkins University Press, 1997.

LEAL, Rafael. Da estrutura à escritura: processos criativos na Dramaturgia seriada. Dissertação (Mestrado em Artes da Cena) - Escola de Comunicação, Universidade Federal do Rio de Janeiro, Rio de Janeiro: 2016.

LINDE, Charlotte. Life stories: the creation of coherence. New York: Oxford University Press, 1993.

LOTZ, Amanda D. Um modelo para a produção de cultura: o modelo do assinante. In: HOLZBACH, Ariane; CASTELLANO, Mayka (orgs.). Televisões: reflexões para além da TV. Rio de Janeiro: E-papers, 2018.

MACHADO, Arlindo. A narrativa seriada. In: A televisão levada a sério. São Paulo: Ed. Senac, 2000.

MACIEL, Luiz Carlos. O poder do clímax: fundamentos do roteiro de cinema e $T V$. Rio de Janeiro: Record, 2003.

MARTÍN-BARBERO, Jesús. Dos Meios às Mediações: Comunicação, Cultura e Hegemonia. 5. ed. Rio de Janeiro: Editora UFRJ, 2008.

MASSAROLO, João; MESQUITA, Dario. Autoprogramação e engajamento nas plataformas de vídeo sob demanda: uma análise da Netflix. In: HOLZBACH, Ariane; CASTELLANO, Mayka (orgs.). Televisões: reflexões para além da TV. Rio de Janeiro: E-papers, 2018.

MANOVICH, Lev. El lenguaje de los nuevos medios de comunicación. Barcelona: Paidós, 2006.

MAYOS, Gonçal. El "efecto Rachomon”: análisis filosófico para el centenario de Akira Kurosawa. Barcelona: Universitat de Barcelona, Departament de Filosofia Teorètica i Pràctica. Facultat de Filosofia. Convivium 23: 209-233, 2010.

MEDIAMORFOSIS TRANSMEDIA. SKAM Case Julie Andem / Mari Magnus ENGLISH - Mediamorfosis 2017, Publicado em 26 de out de 2017 Disponível em: <https://www.youtube.com/watch?v=i6gCzxrtIPs>. Acesso em: 25 jun. 2018.

MITTEL, Jason. Complex TV: the poetics of contemporary television storytelling. Nova York, Londres: New York University Press, 2015. 
Complexidade narrativa na televisão americana contemporânea. São

Paulo: Revista Matrizes, ano 5, n. 2, ed. Jan/jun, ano 2012.

. Television and American Culture. Nova York: Oxford University Press,

2010.

MUNGIOLI, Maria Cristina Palma; PELEGRINI, Christian. Narrativas

Complexas na Ficção Televisiva. Niterói: Revista Contracampo, v. 26, n. 1, ed.

abril, ano 2013.

MURRAY, Janet. Hamlet on the Holodeck: the Future of Narrative in Cyberspace. Cambridge, Massachusets: The MIT Press, 1999.

O'CONNOR, Kelsea. Review: The Secret Diary of Lizzie Bennet. In: Kelsea O'Connor. 22 junho 2014. Disponível em: <http://kelseaoconnor.com/tag/prideand-prejudice/>. Acesso em: 26 jun. 2014.

PALLOTTINI, Renata. Dramaturgia: construção do personagem. São Paulo: Ed. Ática, 1989.

O que é Dramaturgia. São Paulo: Ed. Brasiliense, 2005.

PEMBERLEY DIGITAL. Pemberley Digital Census. 12 nov. 2014. Disponível em: <http://www.pemberleydigital.com/pemberley-digital-census/>. Acesso em: 2 mar. 2015.

The Epic Adventures of Lydia Bennet: Now Coming Fall 2015. 21 jan. 2015. Disponível em: <http://www.pemberleydigital.com/the-epic-adventures-oflydia-bennet-now-coming-fall-2015/>. Acesso em: 8 mar. 2015.

The Lizzie Bennet Diaries DVD...and More!. In: Kickstarter.

Disponível em: <https://www.kickstarter.com/projects/pemberleydigital/thelizzie-bennet-diaries-dvdand-more/posts/874414>. Acesso em: 28 jun. 2014.

Transmedia Storytelling. S.D. Disponível em:

<http://www.tstoryteller.com/transmedia-storytelling>. Acesso em: 11 jun. 2014.

PHILLIPS, Andrea. A Creator's Guide to Transmedia Storytelling: How to Captivate and Engage Audiences Across Multiple Platforms. New York, Chicago, San Francisco: Mc Graw Hill, 2012.

PIUA, Heidi Campana; AFFINI, Letícia Passos. A Estrutura Temporal na Narrativa Complexa: estudo de caso da Série "How to Get Away With Murder". In: Revista Anagrama. São Paulo: ano 11, v. 1, janeiro-junho 2017.

POLLAK, Michael. Memória e identidade social. In: . Estudos Históricos. Rio de Janeiro, v. 5, n.10, 1992

. Memória, esquecimento, silêncio. In: . Estudos Históricos, Rio de Janeiro, v. 2, n.3, 1989. 
PORTAL SKAM. Q\&A | Julie Andem e Mari Magnus [16/09 - São Paulo, Brazil. Publicado em 10 de jan de 2018. Disponível em: <https://www.youtube.com/watch?v=caTZc_DNv_0>. Acesso em: 24 jun. 2018.

PRATTEN, Robert. Getting Started in Transmedia Storytelling: a Practical Guide for beginners. 2011. Disponível em: <http://www.tstoryteller.com/gettingstarted-in-transmedia-storytelling >. Acesso em: 13 ago. 2014.

Transmedia Storytelling. S.D. Disponível em:

<http://www.tstoryteller.com/transmedia-storytelling>. Acesso em: 11 jun. 2014.

RANCIÈRE, Jacques. O fio perdido: ensaios sobre a ficção moderna. São Paulo: Martins Fontes, 2017.

RICOEUR, Paul. Identidade pessoal e identidade narrativa. In: O si-mesmo como um outro. Campinas: Papirus, 1991.

Tempo e Narrativa. Tomo I. Campinas: Papirus, 1994.

Tempo e Narrativa. Tomo II. Campinas: Papirus, 1995.

ROMANO, Aja. Behind the scenes of "The Lizzie Bennet Diaries". In: The Daily Dot. 27 ago. 2012a. Disponível em: <http://www.dailydot.com/interviews/lizziebennet-diaries-cast-interview/>. Acesso em: 22 jan. 2014.

Transmedia and the New Art of Storytelling. In: The Daily Dot. 23 out. 2012b. Disponível em: <http://www.dailydot.com/entertainment/transmediastorytelling-roundtable-bernie-su/>. Acesso em: 26 jun. 2014.

ROSE, Frank. The Art of Immersion: How the Digital Generation is Remaking Hollywood, Madison Avenue, and the Way We Tell Stories. New York, London: W. W. Norton, 2012.

RYAN, Marie-Laure (org.). Narrative Across Media: the Languages of Storytelling. Lincoln, London: University of Nebraska Press, 2004.

SARLO, Beatriz. Tempo passado: cultura da memória e guinada subjetiva. São Paulo: Companhia das Letras, 2007

SCHAFFER, Eva Rose. A Review of the Werther Effect and Depictions of Suicide: 13 Reasons Why. In: UC Merced Undergraduate Research Journal. UC Merced, University of California, Merced: 2018. Disponível em: <https://escholarship.org/content/qt8vr9n8bf/qt8vr9n8bf.pdf>. Acesso em: fevereiro de 2020.

SCHNITZER, Adam. The POV shot. Canal CG Layout. Youtube. 31 ago. 2016. Disponível em: <https://www.youtube.com/watch?v=ScRPUZuFhd8>. Acesso em: outubro de 2018. 
SCREENPRISM. The four best reasons to use pov shots. Canal The Take. Direção Debra Minoff \& Susannah McCullough. Youtube. 2 ago. 2017.

Disponível em: <https://www.youtube.com/watch?v=CHbUbEiQvsI >. Acesso em: outubro de 2018.

SCOLARI, Carlos Alberto. Ecología de la hipertelevisión. Complejidad narrativa, simulación y transmedialidad en la television contemporánea. In: SQUIRRA, Sebastião, FECHINE, Yvana (Orgs.). Televisão digital: desafios para a comunicação. Livro da Compós, 2009. Porto Alegre: Sulina, 2009.

SÉRIE SERIES. Case study: Skam \& \#hashtag, Publicado em 30 de set de 2016. Disponível em: <https://www.youtube.com/watch?v=-quRTMXfd2k>. Acesso em: 24 jun. 2018.

SHIRKY, Clay. A Cultura da Participação: Criatividade e Generosidade no Mundo Conectado. Rio de Janeiro: Zahar, 2011.

SKAM SERIESABLE. The Problematic Elements in Skam. Publicado em 6 de mar de 2018. Disponível em:

<https://www.youtube.com/watch?v=_uz4Zn5bSlE>. Acesso em: 24 jun. 2018.

STARLING, Cássio. Em tempo real: Lost, 24 Horas, Sex and the City e o impacto das novas séries de TV. São Paulo: Alameda, 2006.

SU, Bernie. FAQ and Emma Approved's videos... who knows about the videos?. In: Pemberley Digital Tumblr. 17 out. 2013a. Disponível em: $<$ http://pemberleydigital.tumblr.com/post/64296764902/faq-and-emmaapproveds-videos-who-knows-about-the>. Acesso em: 26 jun. 2014.

LBD - Balancing Transmedia and Lizzie showing/saying stuff that probably should be private. In: Bernie Tumbles. 5 Fev. 2013b. Disponível em: <http://berniesu.tumblr.com/post/42387800659/lbd-balancing-transmedia-andlizzie-showing-saying>. Acesso em: 26 jun. 2014.

TEDEBRING, Edvin. SKAM - En bra serie eller ett utmärkt transmediafenomen? En studie om RKKs framgangsrika transmediaproduktion SKAM. Projeto de Licenciatura em Produção de Mídia Digital no Mestrado Umea: Umea University: 2017.

TEDX TALKS. SKAM - Everything is love | Håkon Moslet | TEDxArendal. Publicado em 17 de out de 2017. Disponível em: <https://www.youtube.com/watch?v=qTsruyZ1HEw>. Acesso em: 24 jun. 2018.

TRILLING, Lionel. Sinceridade \& Autenticidade: a vida em sociedade e a afirmação do eu. São Paulo: É realizações Editora, 2014.

VAROTSIS, George. Approaching the screenplay as a complex system: underlying mechanics, interrelating dynamicsand the plot-algorithmic process. Tese (Philosophy in the School of English, Drama and American \& Canadian Studies) - University of Birmingham, Birmingham: 2013. 
WIEBE, Richard. Cinematography, point of view. W. W. Norton \& Co. 2010. Youtube, 24 fev. 2013. Disponível em:

<https://www.youtube.com/watch?v=JWWP3UKOEFs>. Acesso em: outubro de 2018 .

WIEVIORKA, Annette. L'ère du témoin. In: . L'ère du témoin. Paris: Plon, 1998.

WILLEMSEN, Steven Petrus Martinus. The Cognitive and Hermeneutic Dynamics of Complex Film Narratives. Tese - Groningen, University of Groningen: 2018. Disponível em: <https://www.rug.nl/research/portal/files/53420528/Complete_thesis.pdf>. Acesso em: janeiro de 2020.

XAVIER, Ismail. Do texto ao filme: a trama, a cena e a construção do olhar no cinema. In: PELLEGRINI, Tânia... [et al.]. Literatura, cinema e televisão. São Paulo: Editora Senac São Paulo / Instituto Itaú Cultural, 2003.

\section{Sites e redes sociais dos objetos de estudo analisados:}

BENNET, Jane. Looks by Jane. In: The Lizzie Bennet Diaries. Disponível em: <http://looksbyjane.tumblr.com e http://lookbook.nu/looksbyjane>. Acesso em: 14 set. 2014.

COLLINS AND COLLINS. In. The Lizzie Bennet Diaries [canal no youtube]. 7 episódios. Disponível em: < https://www.youtube.com/watch?v=Dz6eC9o2uY\&list=PL-kgvWgodA8aexGBQoqNqk8aDZjhjqboV\&spfreload=10> . Acesso em: 23 jul. 2014.

EMMA APPROVED. Internet [metasite e blog]. Disponível em: <http://www.emmaapproved.com/>. Acesso em: 14 set. 2014.

[canal no youtube]. 72 episódios mais extras. Postado por: Emma Woodhouse. Disponível em: < https://www.youtube.com/channel/UCVZgtXjbpZkJtybxSnzYcg?spfreload=10>. Acesso em: 14 set. 2014.

PEMBERLEY DIGITAL. [site da empresa]. Disponível em: <http://www.pemberleydigital.com e http://pemberleydigital.tumblr.com/>. Acesso em: 24 jun. 2014. [canal no youtube]. Disponível em: <https://www.youtube.com/user/PemberleyDigital?spfreload=10>. Acesso em: 2 mar. 2015.

In Facebook [Fan page]. Disponível em:

<https://www.facebook.com/PemberleyDigital?fref=ts>. Acesso em: 2 mar. 2015. 
PORTAL SKAM. In Facebook. Disponível em: <https://ptbr.facebook.com/PortalSkam/>. Acesso em: 24 jun. 2018. 25 jun. 2018. Internet [portal]. Disponível em: <http://portalskam.com>. Acesso em: . In Twitter. Disponível em: <https://twitter.com/portalskam>. Acesso em: 22 jun. 2018.

SKAM WIKI. Internet. Disponível em: <http://skam.wikia.com/wiki/Skam_Wiki>. Acesso em: 24 jun. 2018.

THE LIZZIE BENNET DIARIES. [site]. Disponível em: <http://www.lizziebennet.com/>. Acesso em: 23 jul. 2014. [canal no youtube]. 100 episódios. Disponível em: <https://www.youtube.com/channel/UCXfbQAimgtbk4RAUHtIAUww?spfreload $=10>$. Acesso em: 23 jul. 2014 .

In Facebook [Fan page]. Disponível em:

<https://www.facebook.com/LizzieBennetDiaries?ref=hl>. Acesso em: 19 jun. 2014.

In Twitter. Lizzie Bennet [@TheLizzieBennet]; William Darcy [@wmdarcy]; Lydia Bennet [@TheLydiaBennet] et al. Disponível em: <https://twitter.com/TheLizzieBennet>; <https://twitter.com/wmdarcy>; $<$ https://twitter.com/TheLydiaBennet $>$ et al. Acesso em: 19 jun. 2014.

THE LYDIA BENNET. In. The Lizzie Bennet Diaries [canal no youtube]. 29 episódios mais extras. Disponível em: <https://www.youtube.com/channel/UCRt5wuVdwkFYvZdp7Bglhew?spfreload= 10>. Acesso em: 23 jul. 2014.

WELCOME TO SANDITON [online video]. 27 episódios mais extras. Postado por Pemberley Digital. Disponível em:

$<$ https://www.youtube.com/watch?v=9CAsOG1AFME\&list=PL_ePOdUb3xeIJZtHVbO2rtSkoNp63bjR\&spfreload=10>. Acesso em: 24 set. 2014. 


\section{Anexo}

\section{Visão de Alison - Episódio 8, Temporada 3, Parte 1}

O garçom surpreende Alison por já saber que ela teve um grande dia no dia anterior. Se refere ao fato dela ter ganhado a guarda compartilhada de Joanie. Ele diz que gosta de quando os mocinhos ganham. Alison lhe diz que ele é um cara legal.

Ela diz que não sabe o que beber, mas que gostaria de algo forte.

Uma voz lhe sugere um Long Island iced tea

Alison fica um pouco chocada ao ver Helen. Ela diz que estava na cidade e que a viu entrar. Pergunta se ela se importa que ela se sente. Alison diz que não. Helen pede mais um Long Island iced tea para ela e pergunta se ela está bem. Alison confirma e pergunta sobre ela, que diz que já esteve melhor. Faz-se um silêncio. E Alison pergunta se ela quer falar sobre isso. Helen diz que não, mas puxa assunto:

Helen: Então você ainda está morando aqui? Eu não sabia disso.

Alison: Tenho várias razões para estar aqui.

H: Sua filha está aqui, certo?

A: $\operatorname{Sim}$

H: Ela então não é do Noah?

A: Não

Helen sorri.

H: Adorei saber disso. Desculpa não quero parecer uma megera. Estou tendo um dia muito estranho.

A: Sim, eu também.

Ambas bebem, Alison a observa.

A: Tem tido contato com ele recentemente?

H: Noah?

A: Sim, só queria saber como ele tá.

H: Ele na verdade tá hospedado na minha casa.

A: Está?

H: Só por uns dias. O pescoço dele infeccionou e meu namorado é médico, então...

A: Nossa, é muito legal da sua parte. Eles sabem quem fez aquilo? 
H: Não. Acham que foi aleatório.

A: Nossa, é tão estranho

H: Eu sei. (Silêncio) Quando o viu pela última vez?

A: Há alguns dias atrás.

Helen engasga.

H: O quê? Por quê?

A: Assinamos os papéis do divórcio.

H: Você esta divorciada do Noah?

A: Sim.

H: E eu também.

Elas riem e brindam.

$H$ : Ei, posso te pergunta uma coisa?

A: $O k$

H: Quem ele era com você?

A: Como assim?

H: Quero dizer, como você descreveria essa pessoa, Noah Solloway?

A: Não sei, diria que era charmoso, muito inteligente, intensamente motivado. Nunca tinha conhecido alguém tão ambicioso.

Helen ri

A: $O$ que foi?

H: Nada, continue.

A: Ele era muito maduro. Parecia ser um homem que poderia cuidar das coisas. Não era assim que o via?

H: Eu o achava muito inseguro. Obviamente muito inteligente, mas eu sempre precisava pressioná-lo para ligar para o editor ou para enfrentar meu pai.

A: É como se ele fosse outra pessoa com você.

H: Acho que as pessoas veem o querem ver nos outros. Você sabe, eu achava que ele nunca tinha sido realmente seu. Que eu o estava emprestando pra você até ele enjoar e voltar pra casa. Até depois de terem se casado. Não é patético?

A: Helen, eu sinto muito. Eu realmente sinto muito pelo que eu fiz. Ele era seu marido. Vocês tinham filhos. Eu não devia... eu sinto muito.

H: Mas a culpa não é sua. Digo, os homens precisam se sentir importantes para ficar em um relacionamento. E parei de fazer o Noah se sentir importante anos antes de se conhecerem. Então, não se culpe pelo que houve. 
A: Helen, eu quero te contar uma coisa sobre a noite em que Scott morreu.

H: Não conte

A: Não, acho que seria bom que soubesse

H: Por que não esquece isso, Alison? Digo, que diferença faz? Não podemos voltar atrás. Foi bom ver você. Cuide-se.

Em resumo, nesta cena:

- Elas falam sobre Noah e sobre o estranho esfaqueamento.

- Alison diz que também está divorciada de Noah.

- Helen quer saber como Alison via Noah. Isso segue a linha de dúvidas sobre como as pessoas veem Noah que se repete na perspectiva de Helen com pessoas que o conhecem.

- Após descrevê-lo e ouvir a descrição de Helen Alison conclui que ele parecia outra pessoa com ela. Helen diz que acha que as pessoas veem nos outros o quer querem ver.

- Alison diz que sente mal pelo que aconteceu, do caso ter estragado o casamento dela e Helen diz que não foi sua culpa.

- Helen não deixa que Alison fale sobre a noite em que Scott morreu, pois não mudaria nada.

\section{Visão de Helen - Episódio 9, Temporada 3, Parte 1}

Antes dessa cena Helen havia levado os filhos para a casa dos avós em Montauk e confessou para os pais e para as crianças ter atropelado Scott. Ao decidir contar para a mãe dele, seus pais lhe trancam em um quarto de pânico para que pense sobre isso: que os filhos já tiveram o pai preso, não poderiam agora ter a mãe.

Na versão de Helen, ela está no bar e é Alison que chega:

Helen: Alison? Ah meu Deus o que está fazendo aqui?

Alison: Bom, eu moro aqui. O que você faz aqui?

H: Eu trouxe meus filhos pra verem os avós.

A: Como estão as crianças?

H: Estão bem.

A: Sinto falta delas. Pode dizer que mandei lembranças?

$H: O k$.

A: Viu o Noah recentemente? 
H: Sim, eu o vi ontem.

A: Sabem quem fez aquilo?

H: Não, não sabem.

A: Meu Deus, é tão estranho.

H: Muito estranho.

A: Quantos anos Stacey tem agora? Uns 10?

H: Ela tem 11.

A: Waw. Como se diz para alguém de 11 anos: alguém tentou matar seu pai? Desculpe, não quer ouvir isso.

H: Você roubou meu marido.

A: Ok, ok, acho que vamos querer dois Jamesons com gelo

H: Você ao menos se arrepende?

A: Se me arrependo? Sim e não.

Helen ri de nervoso

A: Olha, não acho que sou a única responsável, mas não gosto de saber que as minhas ações fizeram você ou alguém mais sofrer. Ok, eu não planejava roubar Noah. Nós meio que nos encontramos, uma coisa levou a outra, tudo desmoronou e, se eu olhar pra trás e tentar entender posso dizer por que acho que aconteceu. Quem fez o que a quem, mas quanto disso realmente importa, sabe?

Helen fica irritada e a olha para ela com atenção.

H: Importa pra mim. Muito

A: Bem, se quer pensar que foi tudo minha culpa, tudo bem.

H: Alguma coisa é culpa sua?

A: Sim.

H: Me desculpa.

A: Não, tudo bem. Olha, quando eu perdi o Gabriel, parei de acreditar em causa e efeito. E por muito tempo depois, eu... sentia que nada do que eu fazia tinha importância. E foi quando eu conheci Noah. E a ironia é que ele viu minha imprudência com algum tipo de liberdade. Porque era o que ele queria tão desesperadamente. Eu não estava livre. Aquele abandono todo era porque eu não estava dando a mínima. E desde a Joanie eu meio que acordei e comecei a me importar de novo. É muito doloroso às vezes. Sabe, algo mudou. Eu sei que nada, absolutamente nada, dura para sempre. E todo mundo, você, eu, Noah, só podemos 
controlar as nossas próprias escolhas. As de ninguém. Não podemos salvar uns aos outros. Só podemos salvar a nós mesmos.

H: Preciso te contar uma coisa sobre a noite em que Scott morreu.

A: Não precisa.

H: Não preciso?

A: Não, eu sei.

H: O Noah te contou?

A: Não. Eu estava lá

H: O que?

A:É. Eu estava na beira da estrada Helen. Scott e eu brigamos e eu o empurrei

H: Vocêfez o que?

A: Ele estava me atacando.

H: Meu Deus. Noah sabe de tudo isso?

A: Sim.

H: Então quando ele se levantou no tribunal e... e eu sou idiota demais.

A: Não fale assim.

H: Temos que ir a casa de Cherry.

A: Não

H: Sim. Porque ela tem que saber e eu não vou contar sozinha.

A: Não Helen. Do que adiantaria?

H: Sim! Alison, precisamos.

A: Quer saber, Scott era um cara muito perturbado e queria me machucar de qualquer jeito. Lamento pelo que houve com ele, mas não vou à casa da mãe dele com você. De jeito nenhum. Cuide-se Helen.

Alison vai embora e ela que permanece sentada. $\mathrm{O}$ garçom fala com ela. $\mathrm{Na}$ cena seguinte, Helen conta a Vik o que fez. 